MARCO ANTÔNIO BATALHA

\title{
Análise da vegetação da ARIE Cerrado Pé-de-Gigante (Santa Rita do Passa Quatro, SP)
}

São Paulo - SP 
Instituto de Biociências - Universidade de São Paulo

\section{Análise da vegetação da ARIE Cerrado Pé-de-Gigante (Santa Rita do Passa Quatro, SP)}

MARCO ANTÔNIO BATALHA

Dissertação apresentada ao Instituto de Biociências da Universidade de São Paulo, como parte dos requisitos exigidos para a obtenção do título de Mestre em Ecologia.

Orientador: Prof. Dr. Waldir Mantovani

São Paulo - SP 


\section{Agradecimentos}

- Ao Waldir, pela amizade e pela excelente orientação;

- À Fundação de Amparo à Pesquisa do Estado de São Paulo, pela bolsa concedida (processo 95/4290-3);

- À Soninha, pela experiência transmitida durante minha Iniciação Científica, essencial durante este projeto;

- Ao Conselho Técnico do Instituto Florestal, pela autorização para a realização do projeto (processo SMA 43332/95);

- À Vânia Regina Pivello, pelo apoio durante todo o trabalho;

- Ao técnico Paulo César Fernandes (PC), pela ajuda no trabalho de campo, pela amizade e pela bagunça;

- Ao Pé-do-Gigante F.C.: Alberta (e, principalmente, à sua irmã), Cláudia, Cynthia, Daniel (Boi), Glauco, Humberto, Luís e Tozetti (os Totens), Páti e Rafael;

- Àqueles que me ajudaram nas coletas: Amauri, Bia Baker, Claudinha, Marcos Paulo e Soninha;

- Ao Édson, à Soninha e à Patrícia, pela força na aula de qualificação;

- Ao pessoal do Instituto Florestal de Porto Ferreira e de Luís Antônio: Bertoni, Pedro, Waldo, Gonçalves, Marcos e D. Cida;

- Aos curadores e funcionários dos herbários do Instituto de Botânica de São Paulo e do Departamento de Botânica do Instituto de Biociências da Universidade de São Paulo;

- Às pesquisadoras do Instituto de Botânica de São Paulo: Inês Cordeiro, Lúcia Rossi, Maria Lúcia Kawasaki, Rosângela Simão e Tatiana Sendulsky, pelo auxílio na identificação das espécies. 


\section{Sumário}

1. Caracterização da ARIE Cerrado Pé-de-Gigante (Santa Rita do Passa Quatro, SP).

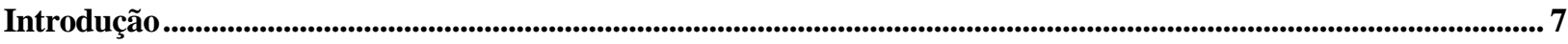

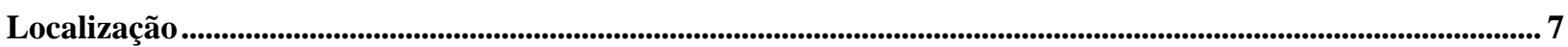

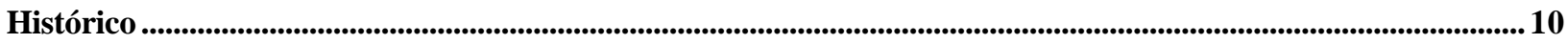

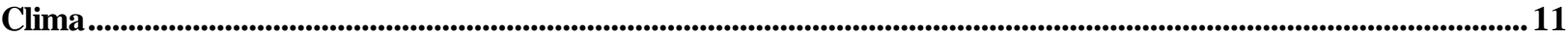

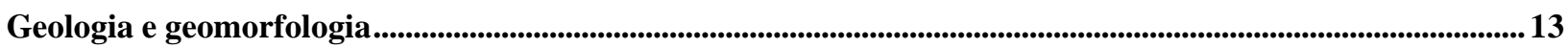

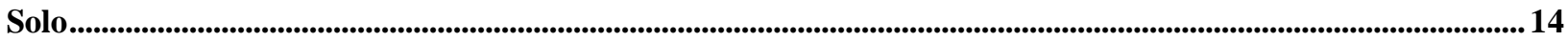

Vegetação

Referências bibliográficas.......................................................................................................................................................................... 26

2. Florística da ARIE Cerrado Pé-de-Gigante (Santa Rita do Passa Quatro, SP). ...........................................................28

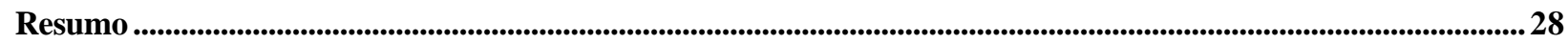

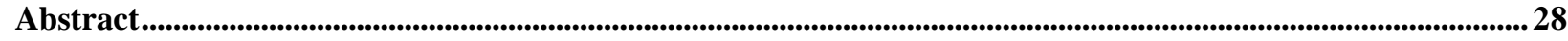

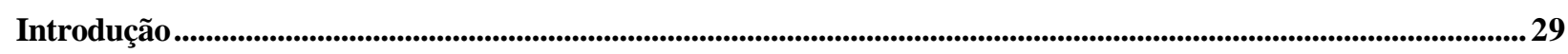

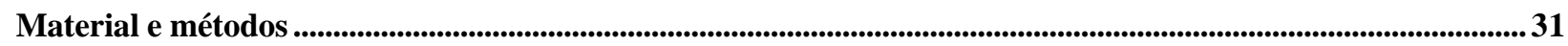

Área de estudo ..................................................................................................................................................................................31

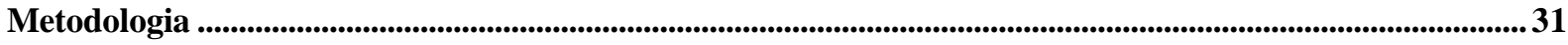

Resultados e discussão _...........................................................................................................................................................................32

Cerrado 'sensu lato' '............................................................................................................................................................... 46

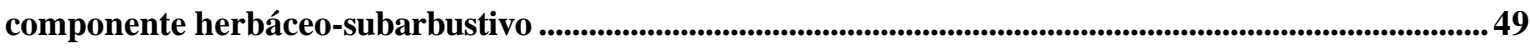

componente arbustivo-arbóreo................................................................................................................................... 52

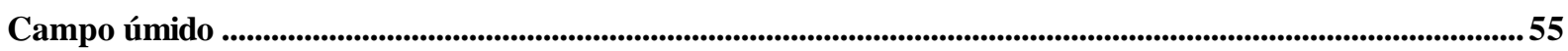

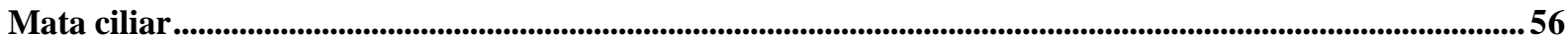

Floresta estacional semidecidual ....................................................................................................................................................57

Referências bibliográficas................................................................................................................................................ 60

3. Chaves de identificação das espécies vegetais vasculares baseada em caracteres vegetativos para a ARIE

Cerrado Pé-de-Gigante (Santa Rita do Passa Quatro, SP) .................................................................................................66

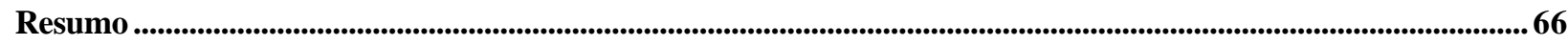


Abstract

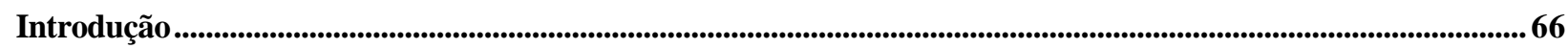

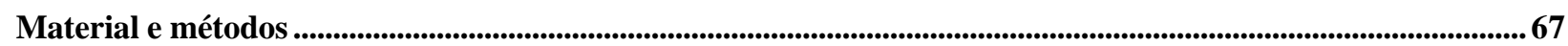

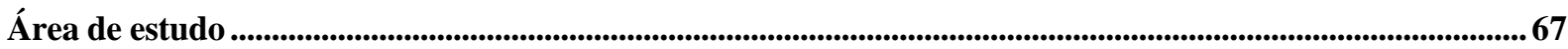

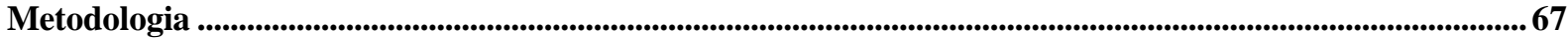

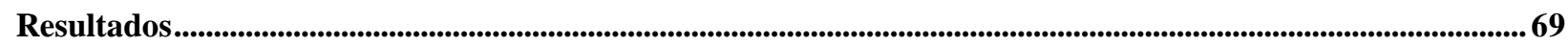

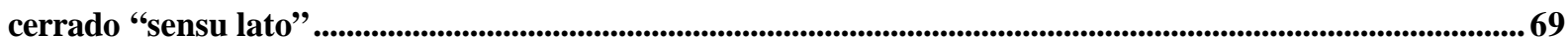

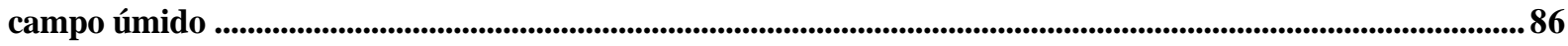

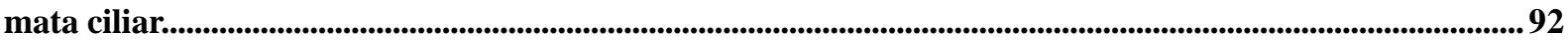

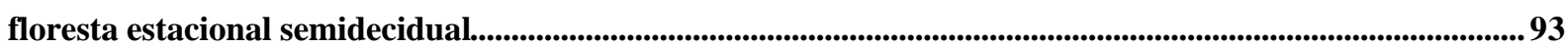

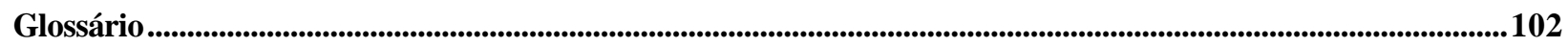

Discussão

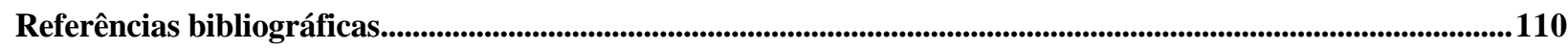

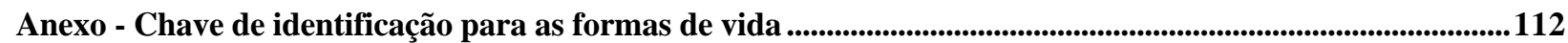

4. Fitossociologia de fisionomias da vegetação na ARIE Cerrado Pé-de-Gigante (Santa Rita do Passa Quatro,

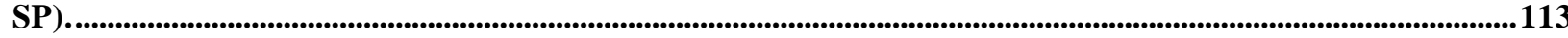

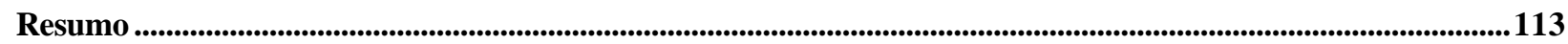

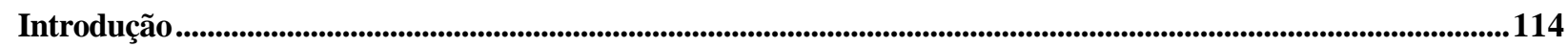

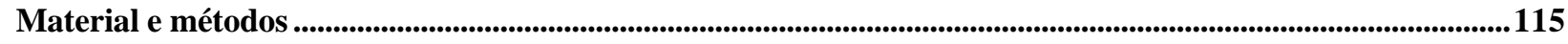

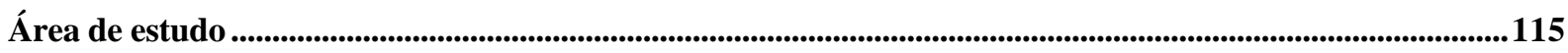

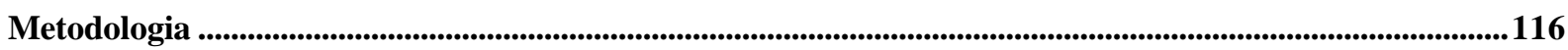

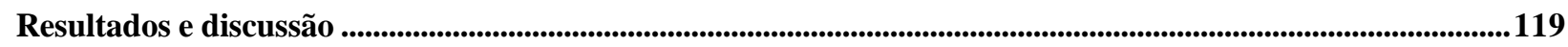

Parâmetros fitossociológicos...................................................................................................................................119

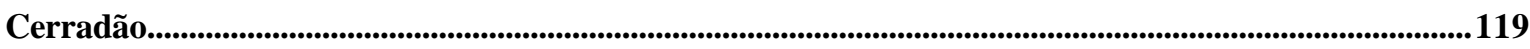

Cerrado "sensu stricto"

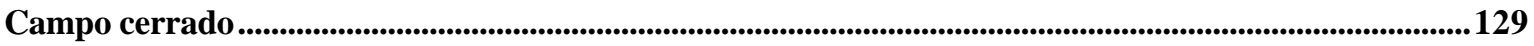

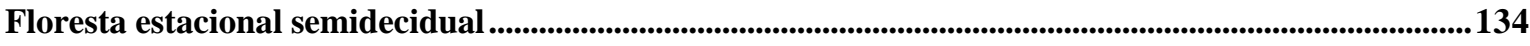

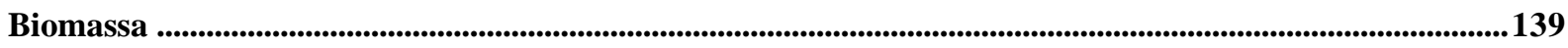

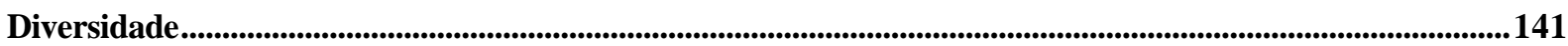


Conclusões .

Referências bibliográficas..............................................................................................................................................................................146

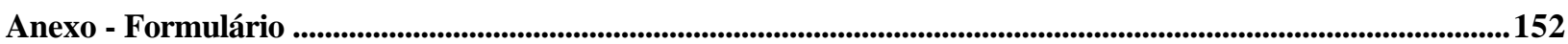

5. Padrões fenológicos das espécies de cerrado 'sensu lato' da ARIE Cerrado Pé-de-Gigante (Santa Rita do Passa

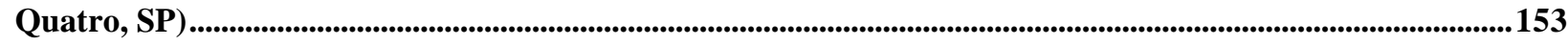

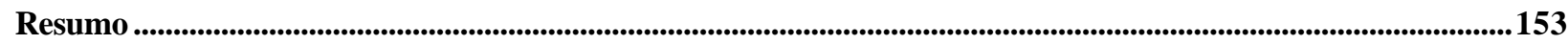

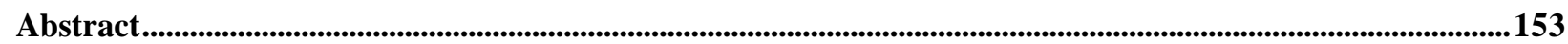

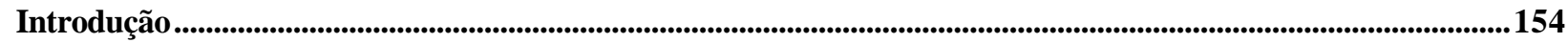

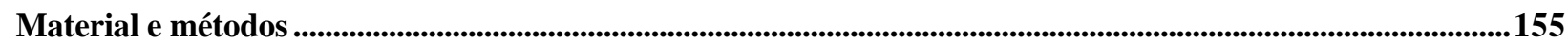

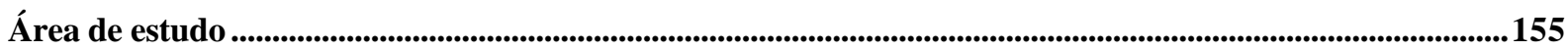

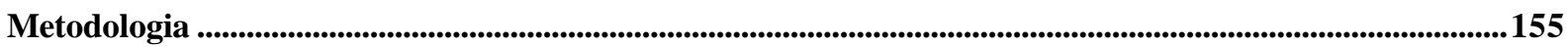

Resultados e discussão ......................................................................................................................................................................156

Adaptações vegetativas ............................................................................................................................................................156

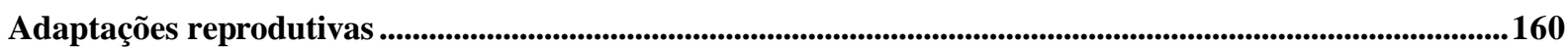

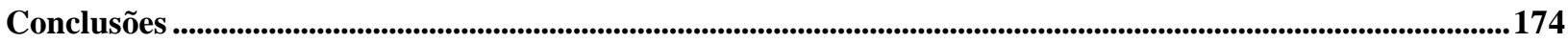

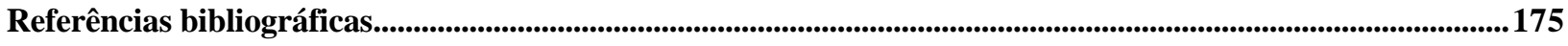




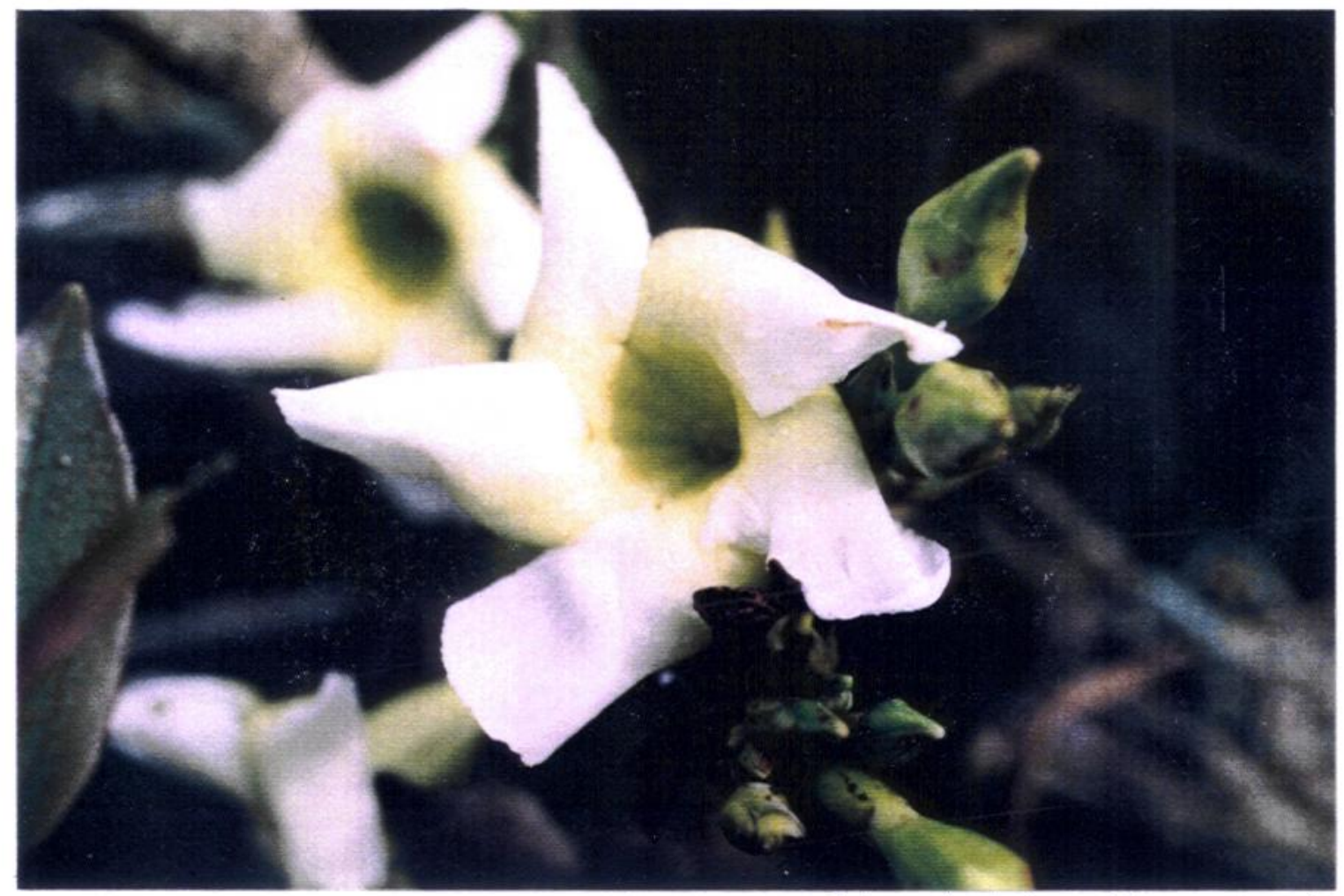

Odontadenia lutea (Apocynaceae) 


\section{Caracterização da ARIE Cerrado Pé-de-Gigante (Santa Rita do Passa Quatro, SP).}

\section{Introdução}

Com o intuito de elaborar um plano de manejo para a Área de Relevante Interesse Ecológico (ARIE) Cerrado Pé-de-Gigante, começaram a ser desenvolvidos por docentes e pós-graduandos dos Laboratórios de Ecologia da Paisagem e Conservação, de Sensoreamento Remoto e de Fitossociologia do Departamento de Ecologia Geral do Instituto de Biociências da Universidade de São Paulo, a partir de 1995, vários estudos nesta área, incluindo o mapeamento da reserva, e sua caracterização geomorfológica, da fauna e da vegetação para fins de conservação.

Este trabalho tem por objetivo a descrição histórica e a caracterização climática, geomorfológica, edáfica e vegetacional da ARIE Cerrado Pé-de-Gigante, sintetizando as informações disponíveis na literatura e obtidas durante o levantamento florístico efetuado nesta área (Capítulo 2).

Os resultados encontrados para a florística, a fitossociologia e a fenologia serão discutidos, respectivamente, nos Capítulos 2, 4 e 5.

\section{Localização}

O presente projeto foi desenvolvido em uma área de vegetação natural de 1269ha, dos quais 1060ha constituem a ARIE Cerrado Pé-de-Gigante. Tal área se localiza no município de Santa Rita do Passa Quatro, estado de São Paulo, próxima ao Parque Estadual de Vassununga, à margem esquerda da Rodovia Anhangüera (SP-330), entre os quilômetros 254,9 e 258,5, aproximadamente

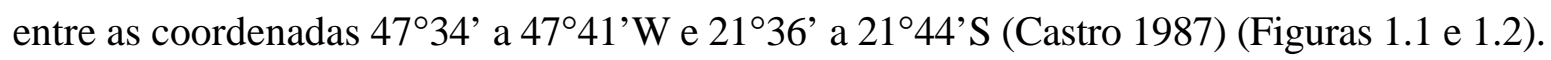




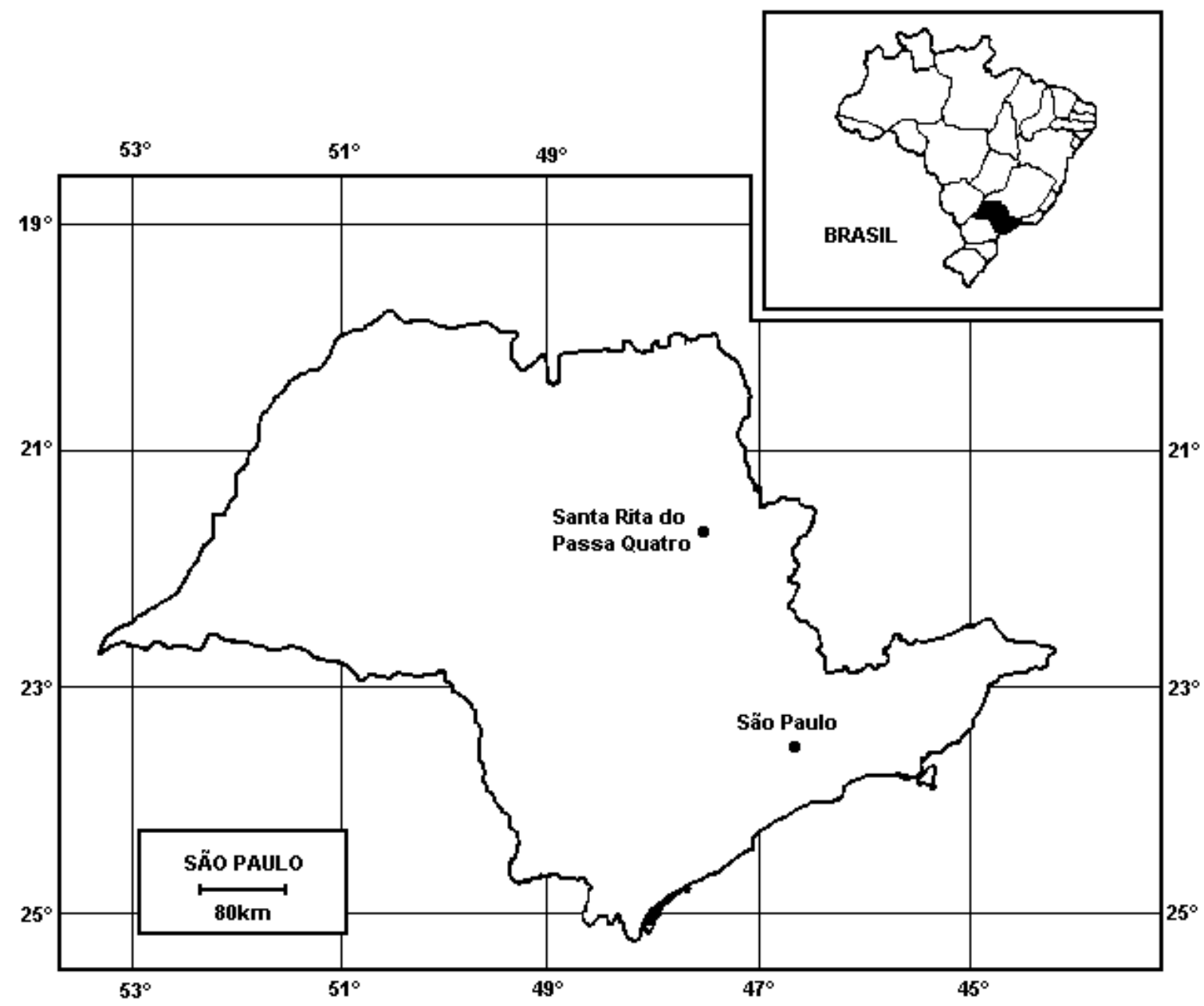

Figura 1.1 - Localização do município de Santa Rita do Passa Quatro no estado de São Paulo (modificado de Salis et al. 1995). 


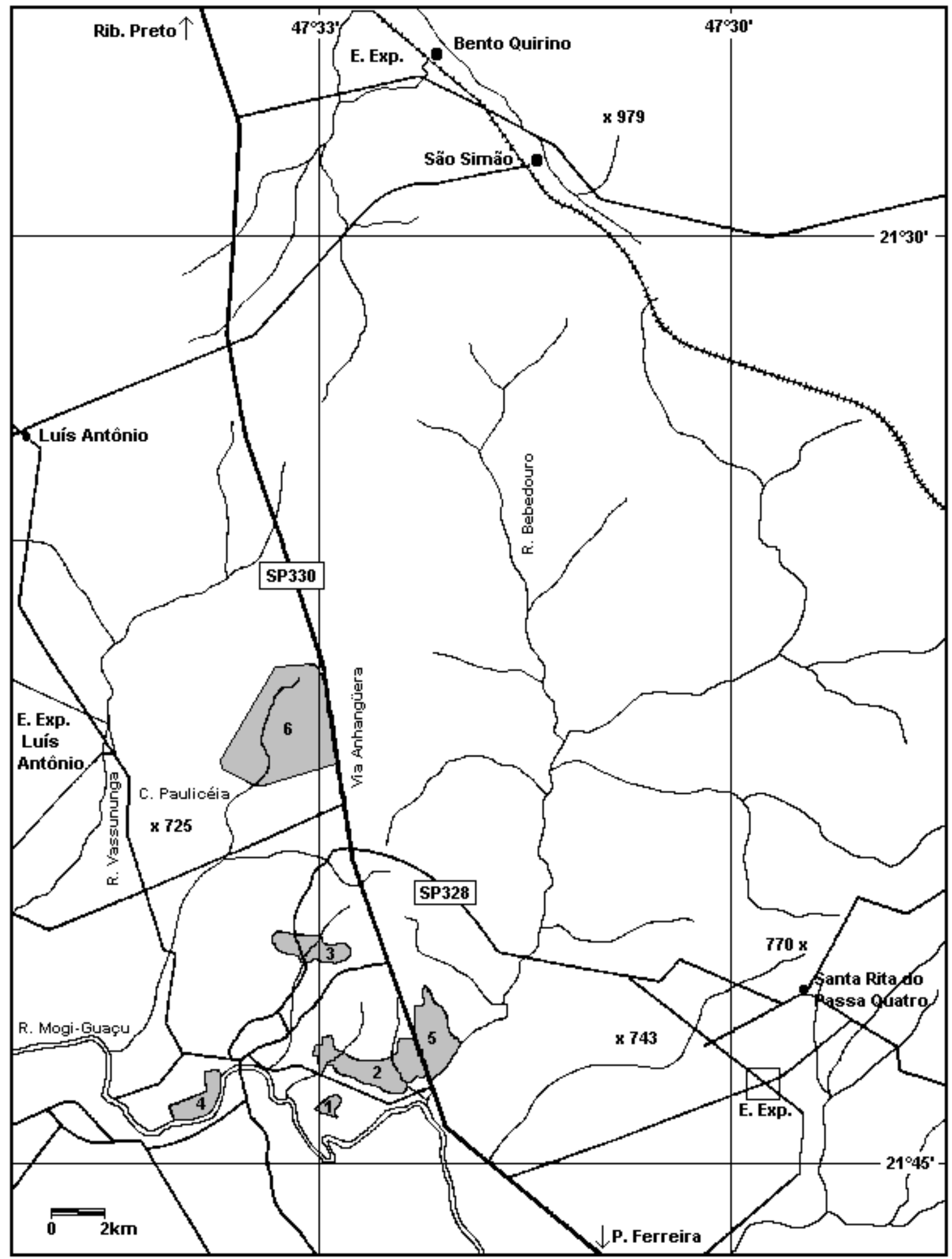

Figura 1.2 - Localização das glebas (1) Capão da Várzea, (2) Capetinga, (3) Praxedes, (4) Maravilha e (5) Capetinga Leste, pertencentes ao Parque Estadual do Vassununga, e da gleba (6) Cerrado Pé-de-Gigante, em Santa Rita do Passa Quatro, SP. 


\section{Histórico}

No final da década de 60, a Usina Açucareira Vassununga decretou falência. Como pagamento das dívidas, o estado recebeu cinco glebas de terra: uma com vegetação de cerrado, a gleba Pé-deGigante, e quatro com cobertura florestal. Estas cinco glebas, com 1484,32ha, através do DecretoLei no 52.546 de 26/10/70, vieram a formar o Parque Estadual de Vassununga, que ficou sob a jurisdição do Instituto Florestal, órgão então subordinado à Secretaria de Agricultura e Abastecimento do Estado de São Paulo (Figura 1.2).

Outra porção de terra, com 1004ha de cerrado, deveria ser incorporada pelo Estado e destinada ao Instituto de Biociências da Universidade de São Paulo. Esta área, que receberia o nome de Reserva Mangaíba, nunca foi anexada pelo Estado devido às imprecisões na sua demarcação.

Uma nova área de 191ha de floresta, através do Decreto no 52.720 de 13/03/71, foi incorporada ao Parque Estadual de Vassununga. Este mesmo decreto excluiu da jurisdição do Parque a gleba Péde-Gigante.

Desse modo, existiam nesta época duas áreas de cerrado: a Reserva Mangaíba e a gleba Pé-deGigante. A Reserva Mangaíba foi, mais tarde, desmatada e usada para o plantio de eucalipto. Em razão disto, a Universidade de São Paulo passou a requisitar a gleba Pé-de-Gigante em substituição à Reserva Mangaíba.

Pelo Decreto Federal no 99.275 de 06/06/90, foi criada a Área de Relevante Interesse Ecológico Cerrado Pé-de-Gigante, com 1060ha. Em 1992, foi encaminhada ao Governo do Estado uma minuta de Decreto que transformaria a ARIE em Estação Ecológica, destinando-a ao Instituto de Biociências da Universidade de São Paulo, a quem caberia também sua administração e fiscalização. Após permanecer três anos sem decisões, o processo foi retomado em 1995 através de entendimento com a Secretaria do Meio Ambiente do Estado de São Paulo. Foi criado oficialmente, 
junto aos Gabinetes do Secretário do Meio Ambiente e do Reitor da Universidade de São Paulo, um Grupo de Trabalho para dar andamento ao processo. Em reunião realizada em 16 de abril de 1996, decidiu-se por uma gestão conjunta da área, a cargo do Instituto de Biociências da Universidade de São Paulo e do Instituto Florestal da Secretaria do Meio Ambiente do Estado de São Paulo, ficando o Grupo de Trabalho responsável por propor os termos do convênio a ser estabelecido entre as duas instituições. A minuta do convênio foi terminada em maio de 1996 e, segundo ela, a responsabilidade sobre as pesquisas realizadas na reserva ficaria com a Universidade de São Paulo e o Instituto Florestal, sendo que este seria responsável também pela sua vigilância. Esta minuta foi apreciada pelo Governador do Estado e aprovada em 11 de julho de 1997.

Contíguos à reserva, na porção sudeste da área, existem mais 209ha - totalizando os 1269ha que foram estudados - que estão sendo pleiteados pela Usina Santa Rita do Passa Quatro. Para esta questão, espera-se, também para breve, uma decisão judicial.

\section{Clima}

De acordo com Nimer (1977), o clima na região de Santa Rita do Passa Quatro é do tipo Tropical subquente, com pelo menos um mês do ano com temperatura média inferior a $18^{\circ} \mathrm{C}$ e temperatura anual média inferior a $22^{\circ} \mathrm{C}$. Pode ser considerado também úmido, com 2 ou 3 meses secos.

Pela classificação de Köppen (1948), o clima enquadra-se na categoria Cwag', ou seja, temperado, macrotérmico, moderadamente chuvoso e com inverno seco não rigoroso.

Os dados climáticos utilizados neste estudo foram coletados entre 1986 e 1995, pela Estação Meteorológica DAEE C4-107, localizada no município de Santa Rita do Passa Quatro (2143'09'’S e $47^{\circ} 28^{\prime} 22^{\prime}$ ' W, altitude de $749 \mathrm{~m}$ ). A partir destes dados, foram construídos os gráficos do diagrama climático (Walter 1986) e do balanço hídrico (Thornthwaite \& Mather 1955), considerando o 
armazenamento de água no solo de $100 \mathrm{~mm}$.

O climadiagrama (Figura 1.3) mostra que o período seco vai de junho a agosto. A pluviosidade anual total e a temperatura anual média corresponderam, respectivamente, a $1499 \mathrm{~mm}$ e $21,5^{\circ} \mathrm{C} . \mathrm{O}$ balanço hídrico (Figura 1.4) indica que entre julho e setembro há déficit de água.

Estação Meteorológica DAEE (C4-107) SANTA RITA DO PASSA QUATRO - SP (21043'09"S, $47^{\circ} 28^{\prime} 22^{\prime \prime} \mathrm{W}$, alt. $\left.749 \mathrm{~m}\right)$ [10]

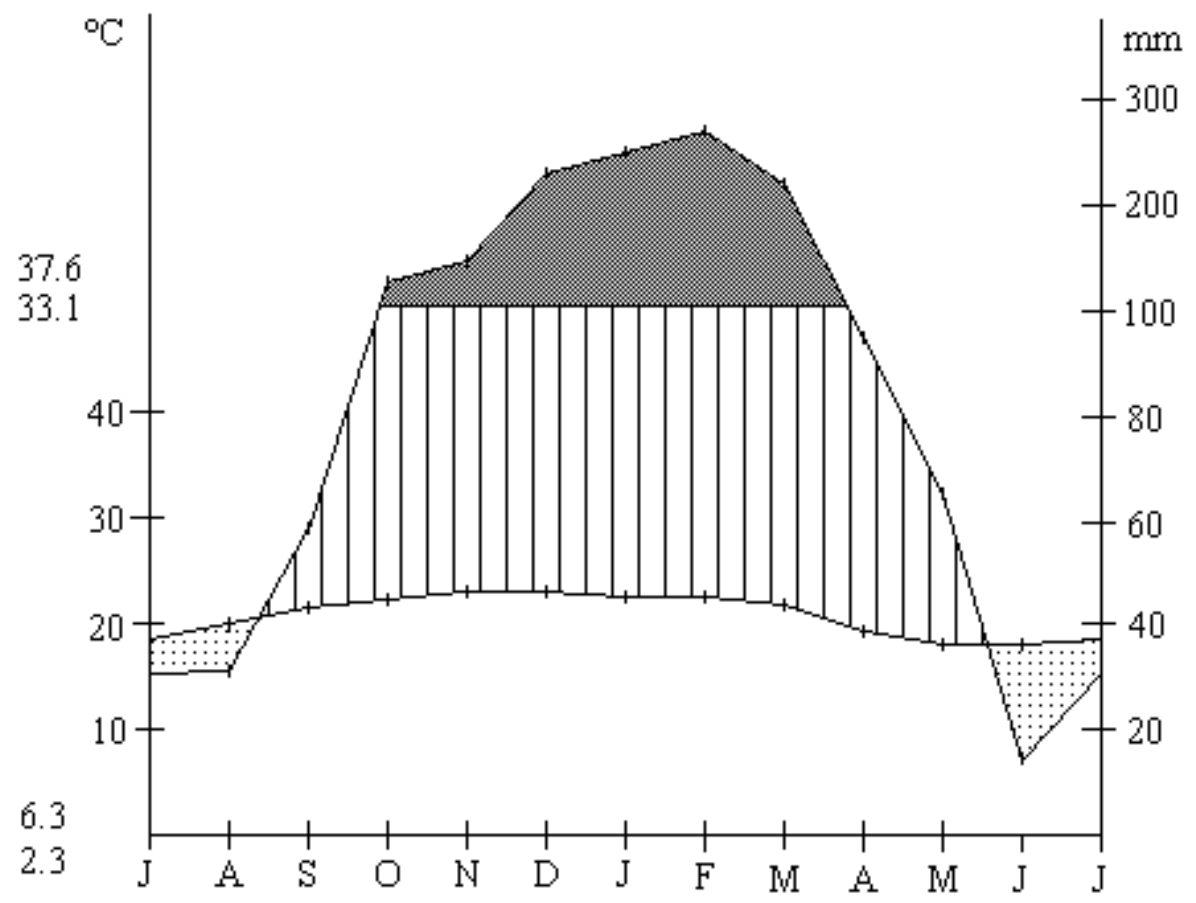

Figura 1.3 - Climadiagrama elaborado a partir dos dados obtidos na estação meteorológica DAEE C4-107, localizada em Santa Rita do Passa Quatro (2143’09'’S e 47²8’22'’W, altitude de 749m), entre os anos de 1986 e 1995. 


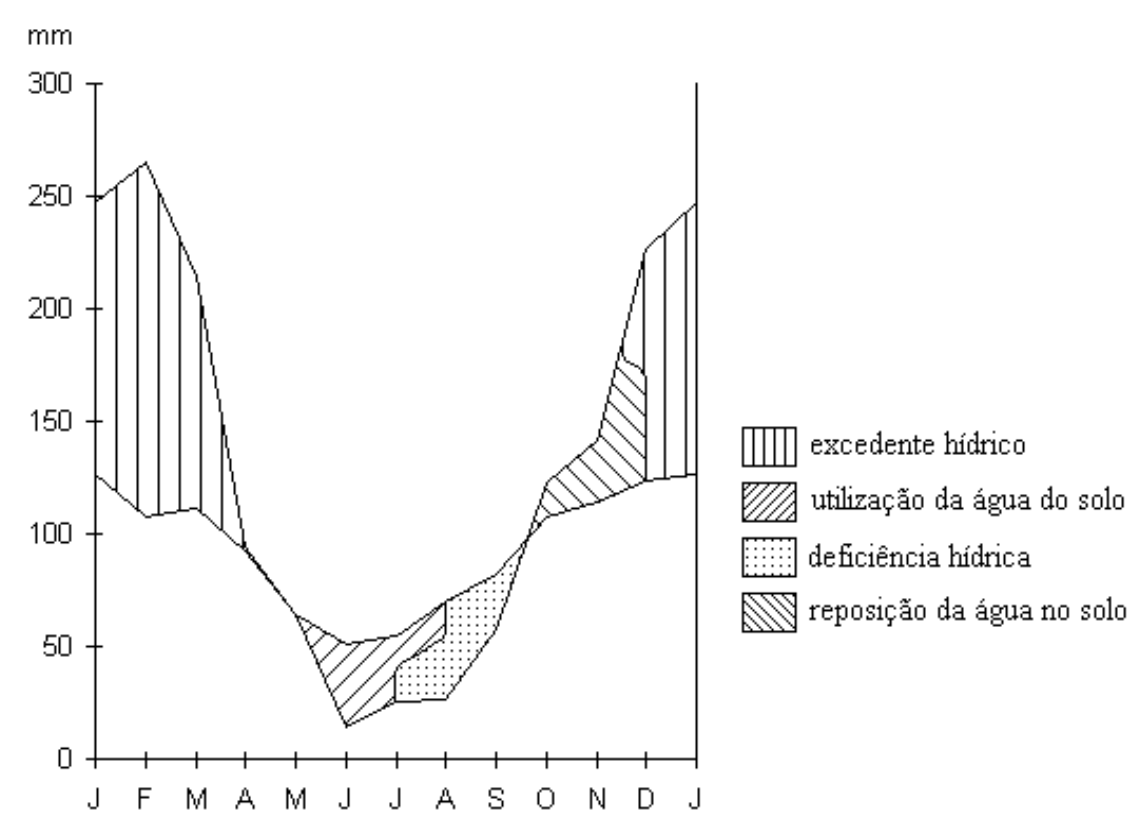

Figura 1.4 - Balanço hídrico elaborado a partir dos dados obtidos na estação meteorológica DAEE C4-107, localizada em Santa Rita do Passa Quatro (2143'09'’S e 47²8'22',W, altitude de 749m), entre os anos de 1986 e 1995.

\section{Geologia e geomorfologia}

A área da reserva está situada sobre a serra de Santa Rita, em cotas altimétricas que variam entre 660 e 730m. O seu nome vem de uma formação geomorfológica decorrente da rede de drenagem do córrego Paulicéia, representada por uma área rebaixada no formato de uma grande pegada (Castro 1987) (Figura 1.5).

Esta área situa-se sobre a Formação Botucatu, que se desenvolveu a partir do Jurássico, há cerca de 190 a 195 milhões de anos (IPT 1981a). No que diz respeito à sua geomorfologia, a gleba se inclui na província da Depressão Periférica (IPT 1981b). A ARIE Pé-de-Gigante, em particular, é enquadrada no grupo de Relevos de Degradação, em Planaltos Dissecados, formados por Relevos de Morros com Encostas Suavizadas, em que predominam baixas declividades e amplitudes locais médias de 100 a 300m, com Morros Amplos, que constituem interflúvios arredondados com mais de $15 \mathrm{~km}^{2}$, topos arredondados a achatados, e vertentes com perfis retilíneos a convexos. A rede de 
drenagem é de baixa densidade, com padrão dendrítico, em vales abertos e planícies aluviais interiores restritas (Guerra 1980, IPT 1981b). As voçorocas são freqüentes e, provavelmente, responsáveis pelas cabeceiras de drenagem com erosão acelerada que, por sua vez, provocaram o rebaixamento daquele terreno com a forma de uma grande pegada.

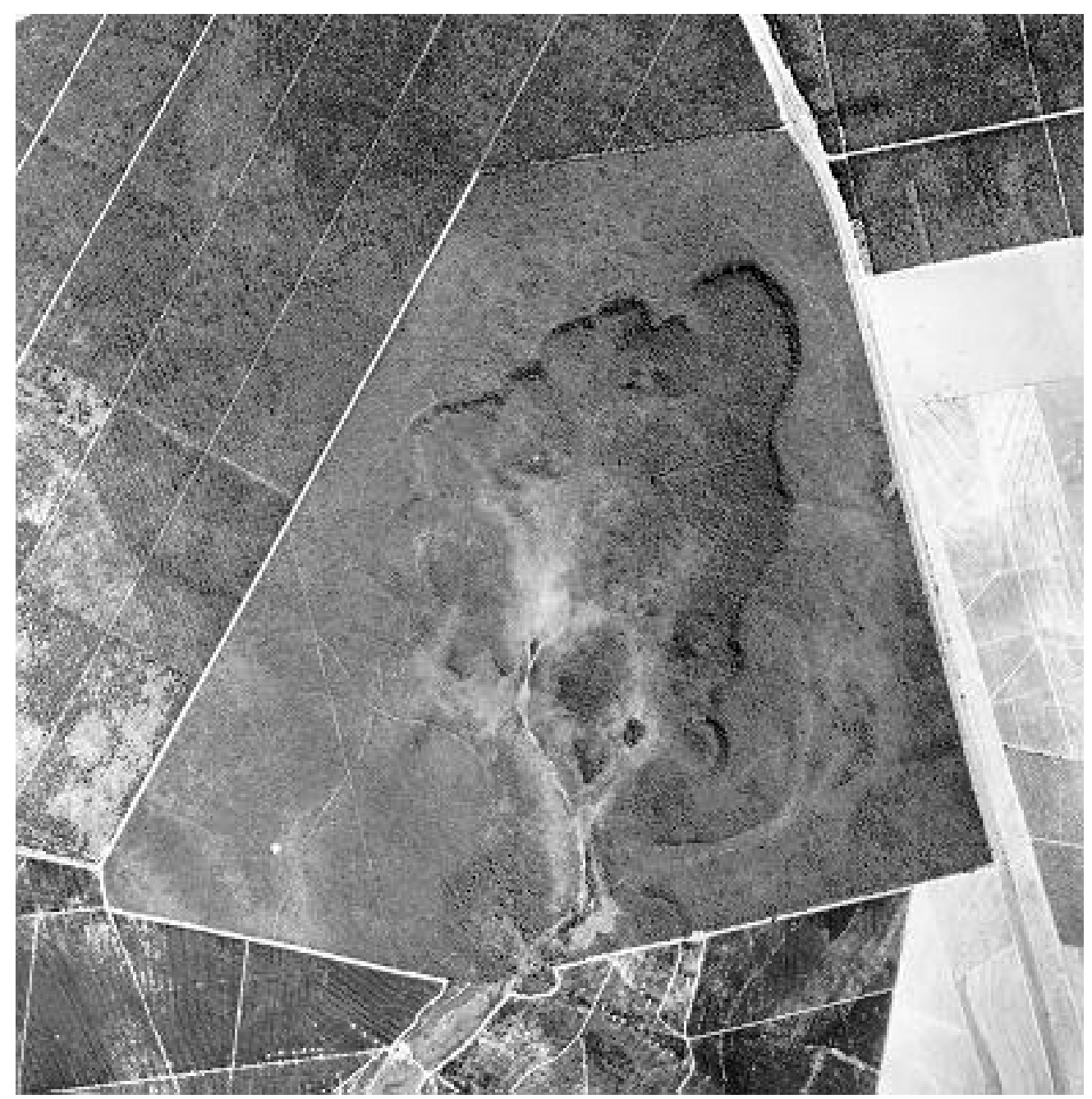

Figura 1.3 - Foto aérea (escala 1:40.000) da ARIE Cerrado Pé-de-Gigante, Santa Rita do Passa Quatro, SP (2136-44’S e $\left.47^{\circ} 34-41^{\prime} \mathrm{W}\right)$.

\section{Solo}

Segundo Oliveira et al. (1982) e Domingues et al. (1987), predominam na região os latossolos 
álicos e distróficos, destacando-se o latossolo Vermelho-Escuro em associação ao latossolo Vermelho-Amarelo. Ambos são solos com horizonte A moderado ou fraco, textura média, profundos, porosos e bem drenados, apresentando boas características físicas para o desenvolvimento radicular das plantas. Possuem bastante homogeneidade vertical e seus subhorizontes são de difícil identificação. São ácidos, com baixos teores de carbono, baixa soma de bases, baixa capacidade de troca de cátions (sempre inferior a 50\%) e, portanto, distróficos.

Ocorrem também na região manchas de latossolo Roxo distrófico, provenientes de derrames basálticos, com maior fertilidade que os solos anteriores, horizonte A fraco e textura mais argilosa. São solos espessos, apresentando também bastante homogeneidade vertical, friáveis e porosos. Possuem elevados teores em ferro total, são ácidos, com soma e saturação em bases baixas, baixa capacidade de troca de cátions, porém, com baixos teores de alumínio trocável. Apresentam textura argilosa em profundidade, sendo a areia fina a fração mais importante depois da argila.

\section{Vegetação}

No interior da reserva, existem variações fisionômicas de cerrado, que vão desde o campo sujo até o cerradão, além de mata ciliar, floresta estacional semidecídua e campo de várzea.

Para a delimitação das áreas de ocorrência das formações e fisionomias de cerrado existentes, utilizou-se, inicialmente, uma imagem de satélite Landsat-5 “Thematic Mapper”, datada de 05 de julho de 1995. Com as informações obtidas a partir de suas bandas TM3 (vermelho) e TM4 (infravermelho próximo), obteve-se um mapa do índice de vegetação da área (Bitencourt et al. 1997, Mesquita Jr. em andamento).

A partir da imagem de satélite (Figura 1.6), com o auxílio de um GPS (Global Positioning System), foram percorridas todas as manchas encontradas, verificando a que tipo de vegetação cada 
uma delas correspondia (Figura 1.7), após o que foram reconhecidas as seguintes formações e fisionomias de cerrado: cerradão, cerrado "sensu stricto", campo cerrado, campo sujo, campo úmido, mata ciliar e floresta estacional semidecídua. Estas formações e fisionomias de cerrado foram representadas por perfis-diagrama, com exceção das lianas:

1. Cerradão (Figura 1.8) - Embora não atinja o máximo grau de desenvolvimento que poderia ser encontrado nesta fisionomia dentro do estado de São Paulo e não haja formação de um dossel, predominam árvores com cerca de $10 \mathrm{~m}$ de altura, que provocam sombreamento e estabelecem microclima mais ameno nos estratos inferiores. O componente herbáceo é pouco desenvolvido, com a presença de muitas plântulas do componente dominante. Observa-se uma camada contínua de serapilheira. Ocupa aproximadamente $11,1 \%$ da área da reserva.

No levantamento fitossociológico realizado nesta fisionomia por Castro (1987), foram amostrados 4.178 indivíduos com diâmetro basal igual ou superior a 3cm, distribuídos em 83 espécies, 64 gêneros e 35 famílias. A densidade total absoluta encontrada foi de 7.863,33 indivíduos por hectare. O valor do índice de diversidade de Shannon foi de 3,399 nat/ind.

2. Cerrado "sensu stricto" (Figura 1.9) - Composto predominantemente por arbustos e arvoretas com cerca de $5 \mathrm{~m}$ de altura, em grande adensamento, dificultando a locomoção e restringindo o campo de visão. Árvores emergentes, com 7 a 10m de altura, surgem eventualmente. O componente herbáceo-subarbustivo é contínuo, mais desenvolvido do que no cerradão. É a fisionomia mais freqüente na reserva, ocupando $79,0 \%$ de sua área total.

3. Campo cerrado (Figura 1.10) - Predomínio do componente herbáceo-subarbustivo, com arbustos de até $2 \mathrm{~m}$ de altura. Árvores com 7 a $10 \mathrm{~m}$ de altura ocorrem esparsamente. Pode-se caminhar facilmente, bem como visualizar grandes distâncias. Cobre cerca de 7,9\% da reserva.

- Campo sujo - Surge nas encostas mais íngremes. Há predominância de gramíneas com cerca de $0,5 \mathrm{~m}$ de altura. Esparsamente, encontram-se arbustos de $2 \mathrm{~m}$ altura aproximadamente. Em muitos 
locais destas encostas, o solo está totalmente exposto. Devido à sua pequena representatividade, cerca de $0,25 \%$ da área da reserva, não foi esquematizada por perfil-diagrama.

4. Campo úmido (Figura 1.11) - Acompanha as áreas de drenagem do córrego Paulicéia, com espécies típicas de solo úmido ou periodicamente inundado. Predominam gramíneas e ciperáceas que podem atingir $1 \mathrm{~m}$ de altura. Nesta formação, que representa aproximadamente $0,55 \%$ da área total da reserva, surgem várias espécies invasoras, que se concentram em grandes manchas, como, por exemplo, Pteridium aquilinum (Dennstaedtiaceae), Achyrocline satureoides (Asteraceae), e Andropogon bicornis, Melinis minutiflora e Panicum parvifolium (Poaceae).

5. Mata ciliar (Figura 1.12) - De dimensões muito pequenas e muito degradada, aparece às margens do córrego Paulicéia, com árvores de 10 a $12 \mathrm{~m}$ de altura, muitas das quais mortas ou cobertas por lianas. Composta, principalmente, por Tapirira guianensis (Anacardiaceae), Croton urucurana e Hyeronima alchorneoides (Euphorbiaceae), e Inga uruguensis (Mimosaceae).

6. Floresta estacional semidecídua (Figura 1.13) - Predominam árvores com altura superior a 15m, formando um dossel, como as de Tabebuia serratifolia (Bignoniaceae), Croton floribundus (Euphorbiaceae) e Platypodium elegans (Fabaceae). Algumas árvores emergentes, principalmente de Anadenanthera macrocarpa (Mimosaceae), atingem cerca de $20 \mathrm{~m}$ de altura. O subosque é dominado por Actinostemon communis (Euphorbiaceae). O componente herbáceo é pouco desenvolvido, formado por espécies tipicamente umbrófilas, como, por exemplo, de Rubiaceae e de Marantaceae. Lianas são freqüentes e há um aumento na quantidade de epífitas em relação às fisionomias de cerrado. A camada de serapilheira é espessa e contínua no interior desta formação, que cobre em torno de $1,2 \%$ da área da reserva. 


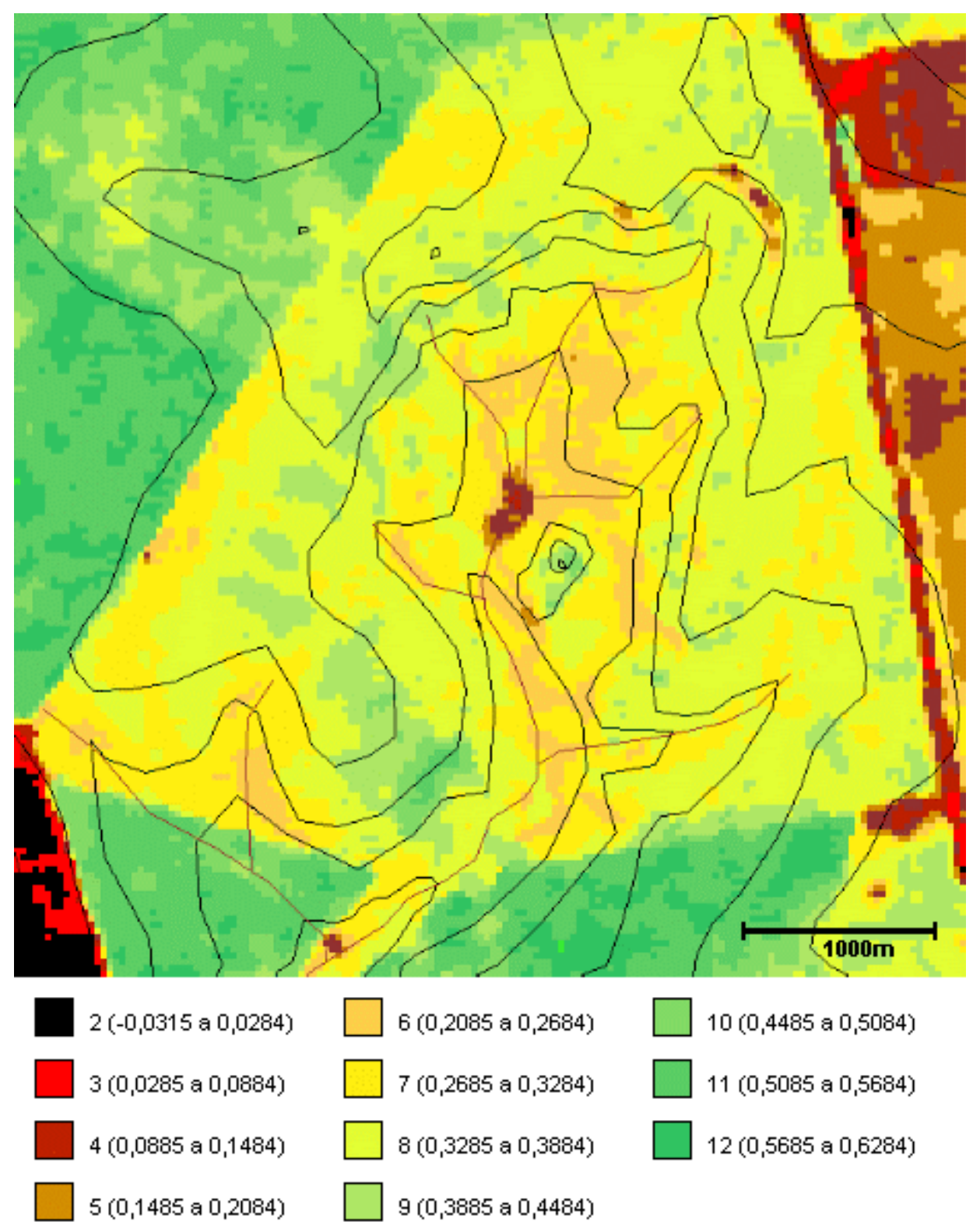

Figura 1.6 - Índice de vegetação obtido a partir das bandas TM3 e TM4 de imagem de satélite Landsat de 05/07/95 (09:45h) da ARIE Cerrado Pé-de-Gigante, Santa Rita do Passa Quatro, São Paulo (21³6-44'S e 47³4-41'W). Legenda: 1, 2, .., 12 = índices de vegetação (segundo Mesquita Jr. em andamento). 


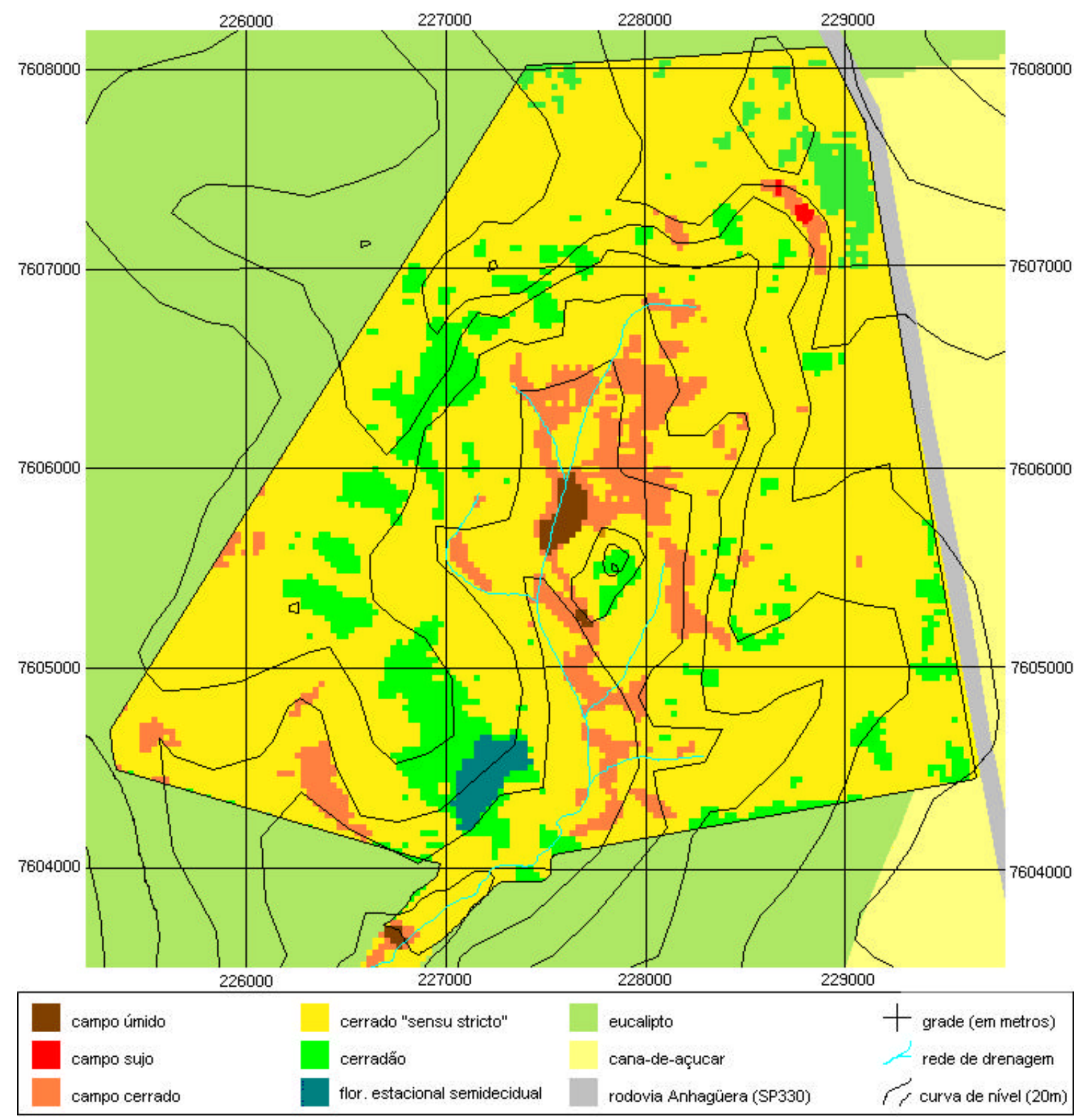

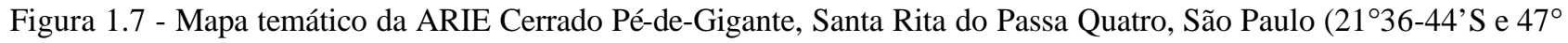
34-41'W). 


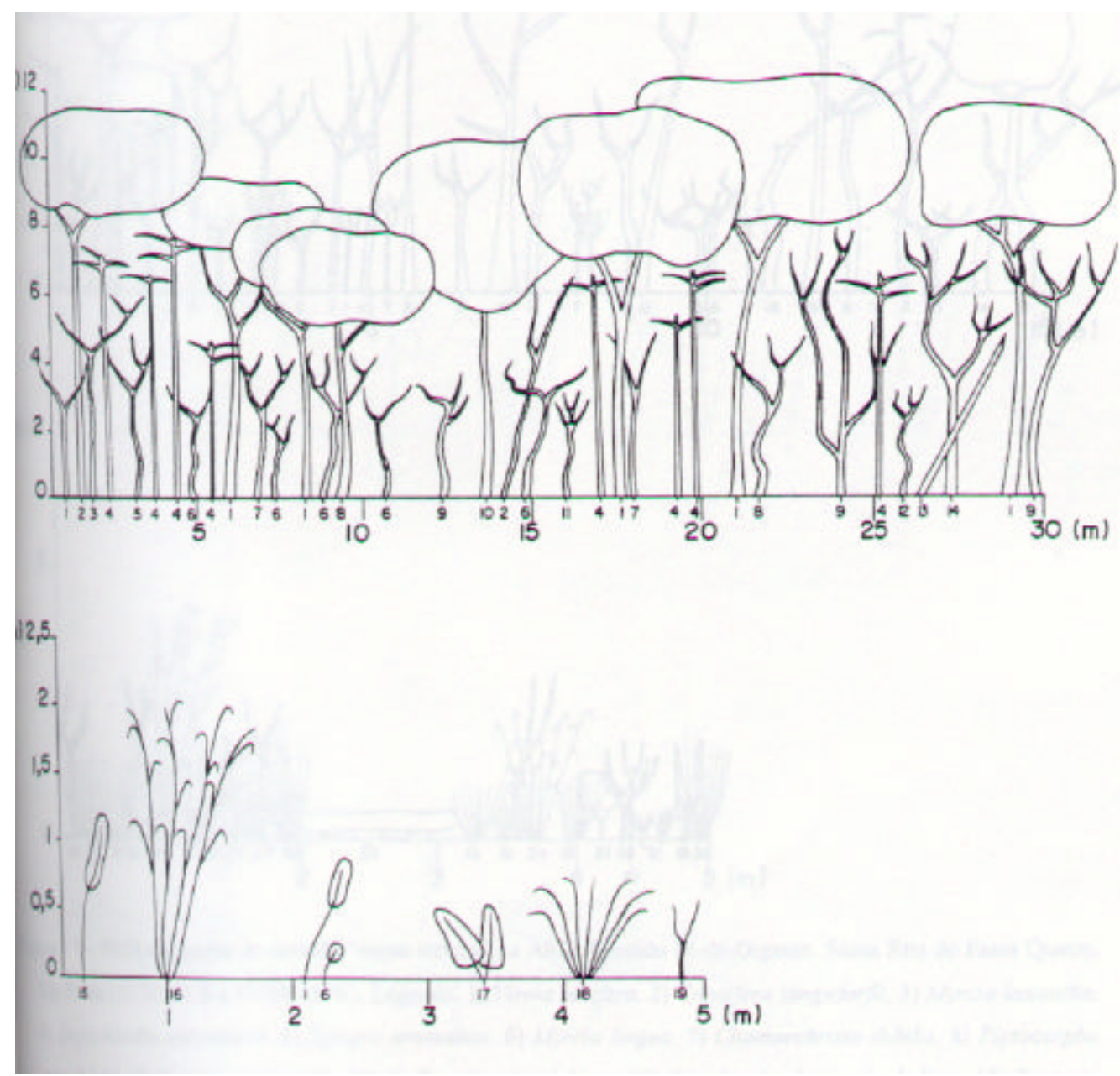

Figura 1.8 - Perfil-diagrama do cerradão na ARIE Cerrado Pé-de-Gigante, Santa Rita do Passa Quatro, São Paulo (21 36-44'S e 47³4-41'W). Legenda: 1) Pterodon pubescens, 2) Anadenanthera falcata, 3) Annona crassiflora, 4) Xylopia aromatica, 5) Machaerium acutifolium, 6) Myrcia lingua, 7) Aspidosperma tomentosum, 8) Qualea grandiflora, 9) Dyptichandra aurantiaca, 10) Copaifera langsdorfii, 11) Miconia albicans, 12) Roupala montana, 13) Morta, 14) Vatairea macrocarpa, 15) Miconia rubiginosa, 16) Rhynchospora exaltata, 17) Polypodium latipes, 18) Ananas ananassoides, 19) Alibertia macrophylla. 


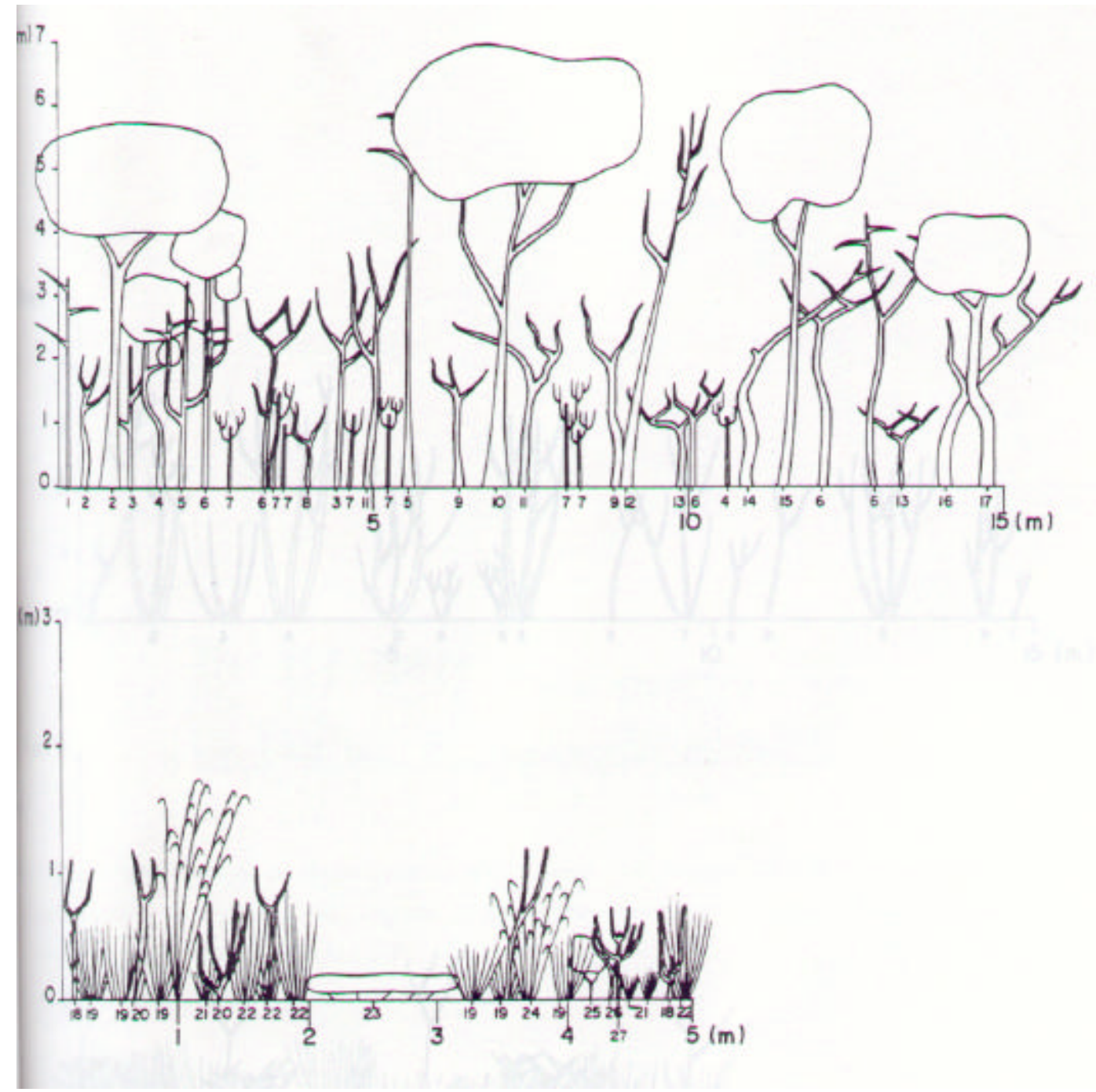

Figura 1.9 - Perfil-diagrama do cerrado "sensu stricto" na ARIE Cerrado Pé-de-Gigante, Santa Rita do Passa Quatro, São

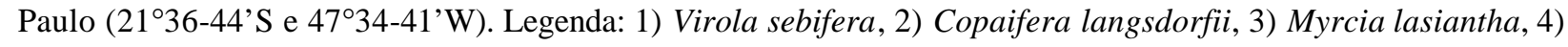
Dyptichandra aurantiaca, 5) Xylopia aromatica, 6) Myrcia lingua, 7) Chamaechrista debilis, 8) Piptocarpha rotundifolia, 9) Ouratea spectabilis, 10) Dalbergia miscolobium, 11) Stryphnodendron polyphyllum, 12) Pouteria torta, 13) Erythroxylum suberosum, 14) Neea theifera, 15) Pterodon pubescens, 16) Annona coriacea, 17) Myrcia uberavensis, 18) Connarus suberosus, 19) Axonopus marginatus, 20) Miconia albicans, 21) Bulbostylis hirtella, 22) Loudetiopsis chrysothrix, 23) Andira laurifolia, 24) Scleria comosa, 25) Chamaechrista desvauxii, 26) Rourea induta, 27) Memora peregrine. 


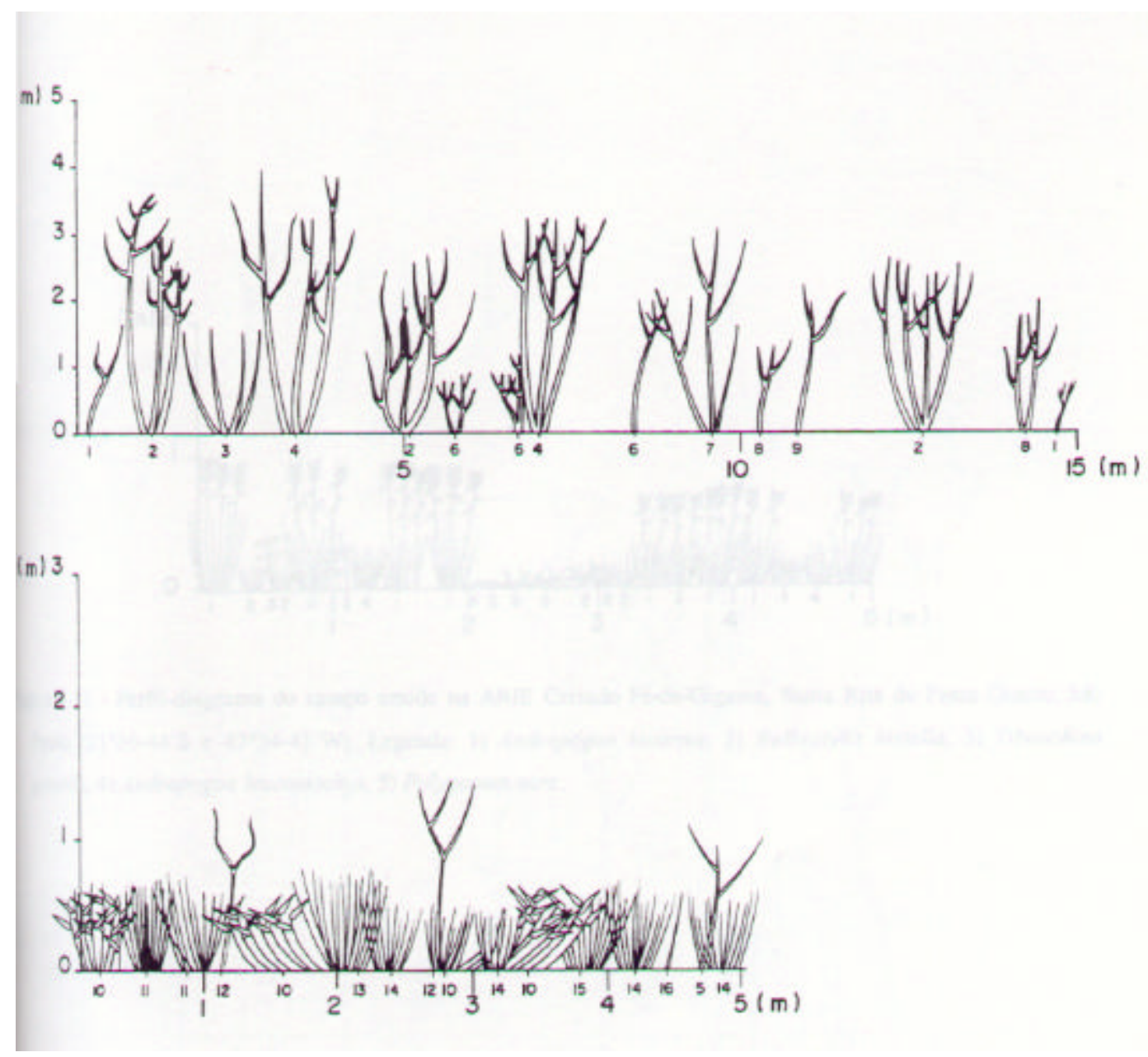

Figura 1.10 - Perfil-diagrama do campo cerrado na ARIE Cerrado Pé-de-Gigante, Santa Rita do Passa Quatro, São Paulo(2136-44'S e 47³4-41'W). Legenda: 1) Psidium australe, 2) Pouteria ramiflora, 3) Vernonia rubriramea, 4) Bauhinia rufa, 5) Byrsonima intermedia, 6) Lippia salviifolia, 7) Kielmeyera variabilis, 8) Caryocar brasiliense, 9) Stryphnodendron adstringens, 10) Melinis minutiflora, 11) Axonopus marginatus, 12) Campomanesia pubescens, 13) Tristachya leiostachya, 14) Axonopus barbigerus, 15) Loudetiopsis chrysothrix, 16) Peixotoa tomentosa. 


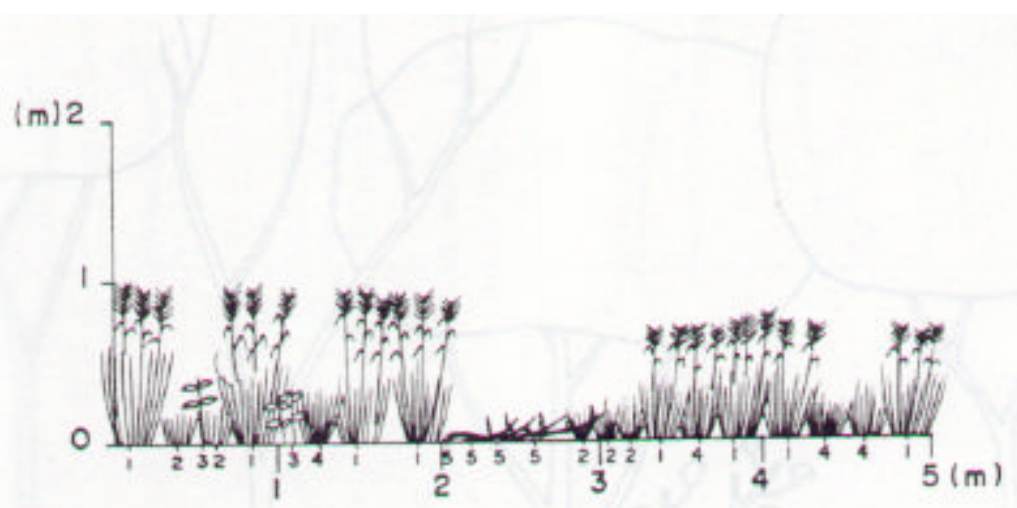

Figura 1.11 - Perfil-diagrama do campo úmido na ARIE Cerrado Pé-de-Gigante, Santa Rita do Passa Quatro, São Paulo

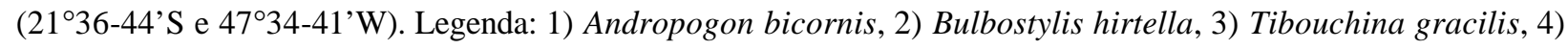
Andropogon leucostachys, 5) Polygonum acre. 


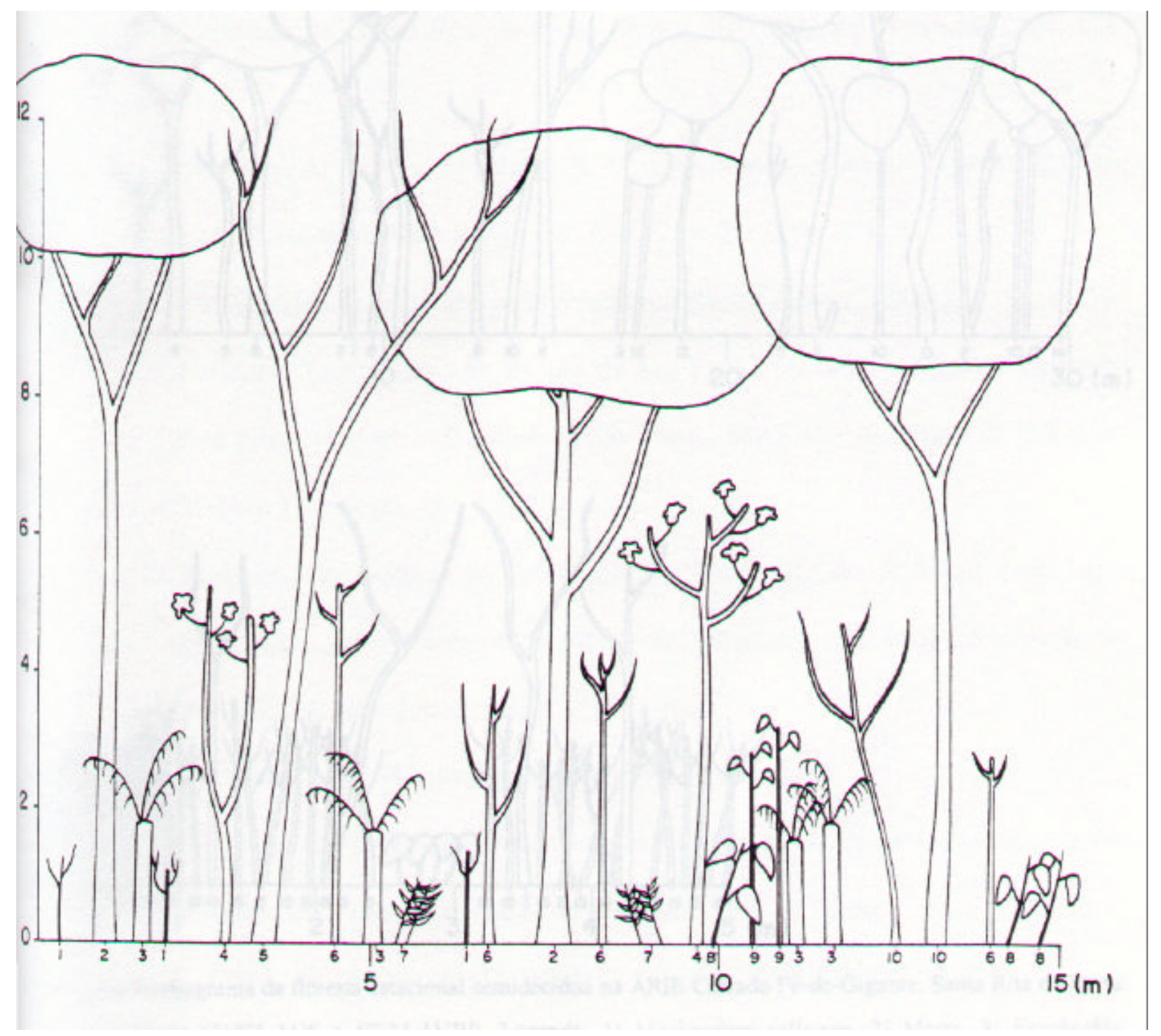

Figura 1.12 - Perfil-diagrama da mata ciliar na ARIE Cerrado Pé-de-Gigante, Santa Rita do Passa Quatro, São Paulo (21 ○36-44’S e 47³4-41’W). Legenda: 1) Siparuna apiosyce, 2) Inga uruguensis, 3) Cyathea delgadii, 4) Cecropia pachystachya, 5) Morta, 6) Hyeronima alchorneoides, 7) Thelypteris salzmanii, 8) Heliconia hirsuta, 9) Croton urucurana, 10) Tapirira guianensis. 

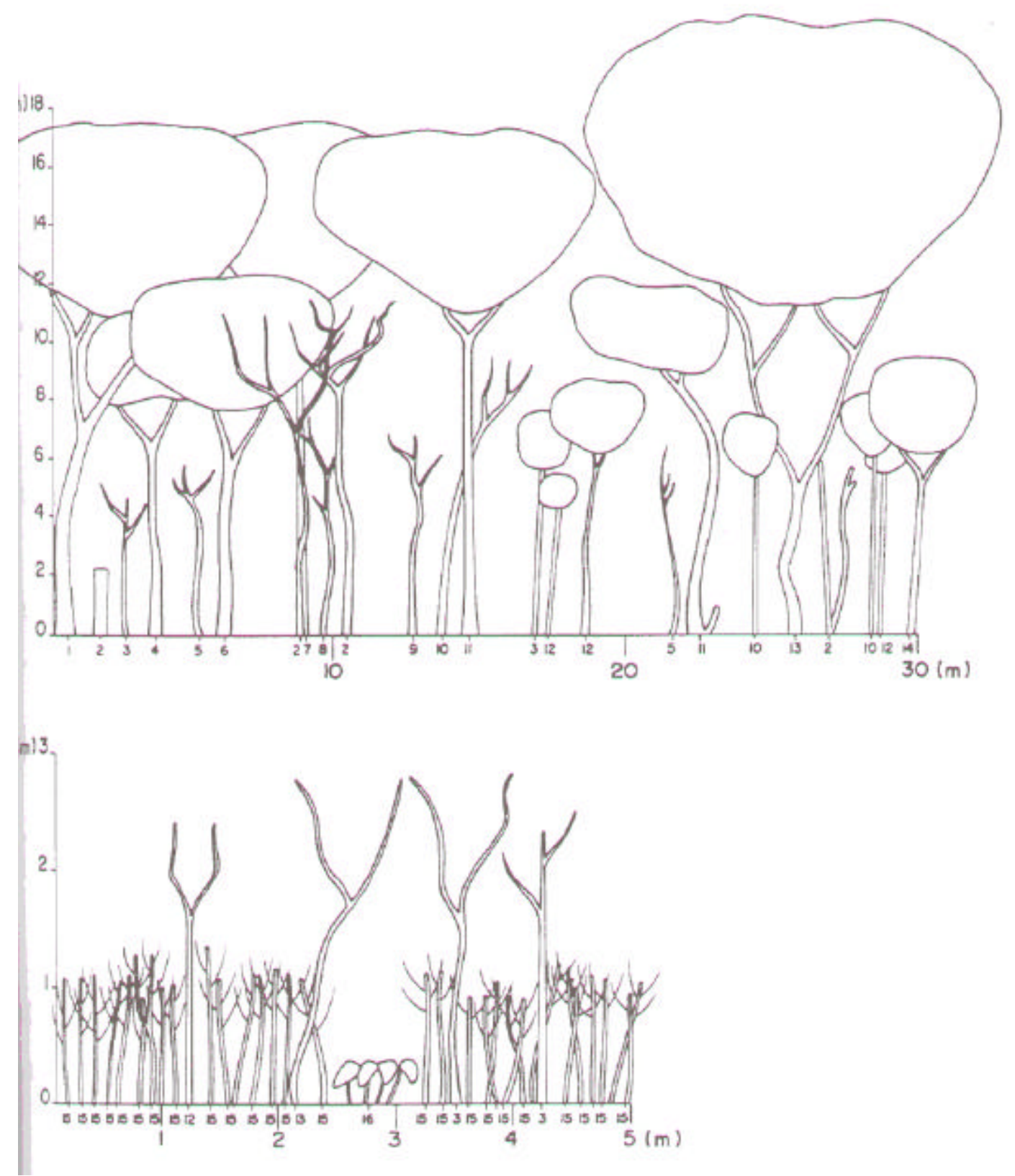

Figura 1.13 - Perfil-diagrama da floresta estacional semidecídua na ARIE Cerrado Pé-de-Gigante, Santa Rita do Passa

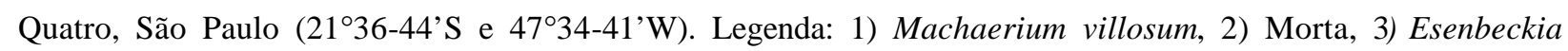
febrifuga, 4) Copaifera langsdorfii, 5) Ocotea corymbosa, 6) Tabebuia serratifolia, 7) Cordia sellowiana, 8) Lacistema floribundum, 9) Matayba elaeagnoides, 10) Croton floribundus, 11) Platypodium elegans, 12) Cupania vernalis, 13) Anadenathera macrocarpa, 14) Dalbergia frutescens, 15) Actinostemon communis, 16) Calathea zebrina. 


\section{Referências bibliográficas}

BITENCOURT, M. D.; MESQUiTA JR., H. N.; MANTOVANI, W.; BATAlHA, M. A. \& PIVELLO, V. R. 1997. Identificação de fisionomias de cerrado com imagem índice de vegetação. In: LEITE, L. L. \& SAITO, C. H (eds). Contribuição ao conhecimento ecológico do cerrado. Brasília, Univ. Brasília.

CASTRO, A. A. J. F. 1987. Florística e fitossociologia de um cerrado marginal brasileiro, Parque Estadual de Vassununga, Santa Rita do Passa-Quatro, SP. Tese de Mestrado. Univ. Est. Campinas.

DOMINGUES, E. N.; SILVA, D. A. \& PFEIFER, R. M. 1987. Reconhecimento da geomorfologia e solos do Parque Estadual de Vassununga, SP. Bol. Técn. IF. 41(2): 271-90.

GUERRA, A. T. 1980. Dicionário geológico-geomorfológico. Rio de Janeiro, IBGE.

IPT. Instituto de Pesquisas Tecnológicas do Estado de São Paulo. Divisão de Minas e Geologia Aplicada. 1981a. Mapa geológico do estado de São Paulo. São Paulo, Secretaria da Indústria, Comércio, Ciência e Tecnologia. v1.

IPT. Instituto de Pesquisas Tecnológicas do Estado de São Paulo. Divisão de Minas e Geologia Aplicada. 1981b. Mapa geomorfológico do estado de São Paulo. São Paulo, Secretaria da Indústria, Comércio, Ciência e Tecnologia. v1.

KÖPPEN, W. 1948. Climatologia. México, Fondo de Cultura Económica.

MESQUITA JR., H. N. de. Em andamento. Identificação de fisionomias de cerrado com imagem índice de vegetação. São Paulo. Dissertação de Mestrado. Univ. S. Paulo.

NIMER, E. 1977. Clima. In: FUNDAÇÃO INSTITUTO BRASILEIRO DE GEOGRAFIA E ESTATÍSTICA (ed.). Geografia do Brasil: Região Sudeste. Rio de Janeiro, IBGE. v3.

OLIVEIRA, J. B.; PRADO, H. \& ALMEIDA, C. L. F. 1982. Levantamento pedológico 
semidetalhado do estado de São Paulo (escala 1:100.000), quadrícula de Descalvado. Rio de Janeiro, EMBRAPA, SAA, CPA e IAC.

SALIS, S. M.; SHEPHERD, G. J. \& JOLY, C. A. 1995. Floristic comparison of mesophytic semidecidous forests of the interior of the state of São Paulo, Southeast Brazil. Vegetatio 119: $155-64$.

THORNTHWAITE, C. W. \& MATHER, J. R. 1955. The water balance. Climatology 8: 104.

WALTER, H. 1986. Vegetação e zonas climáticas. São Paulo, EPU. 


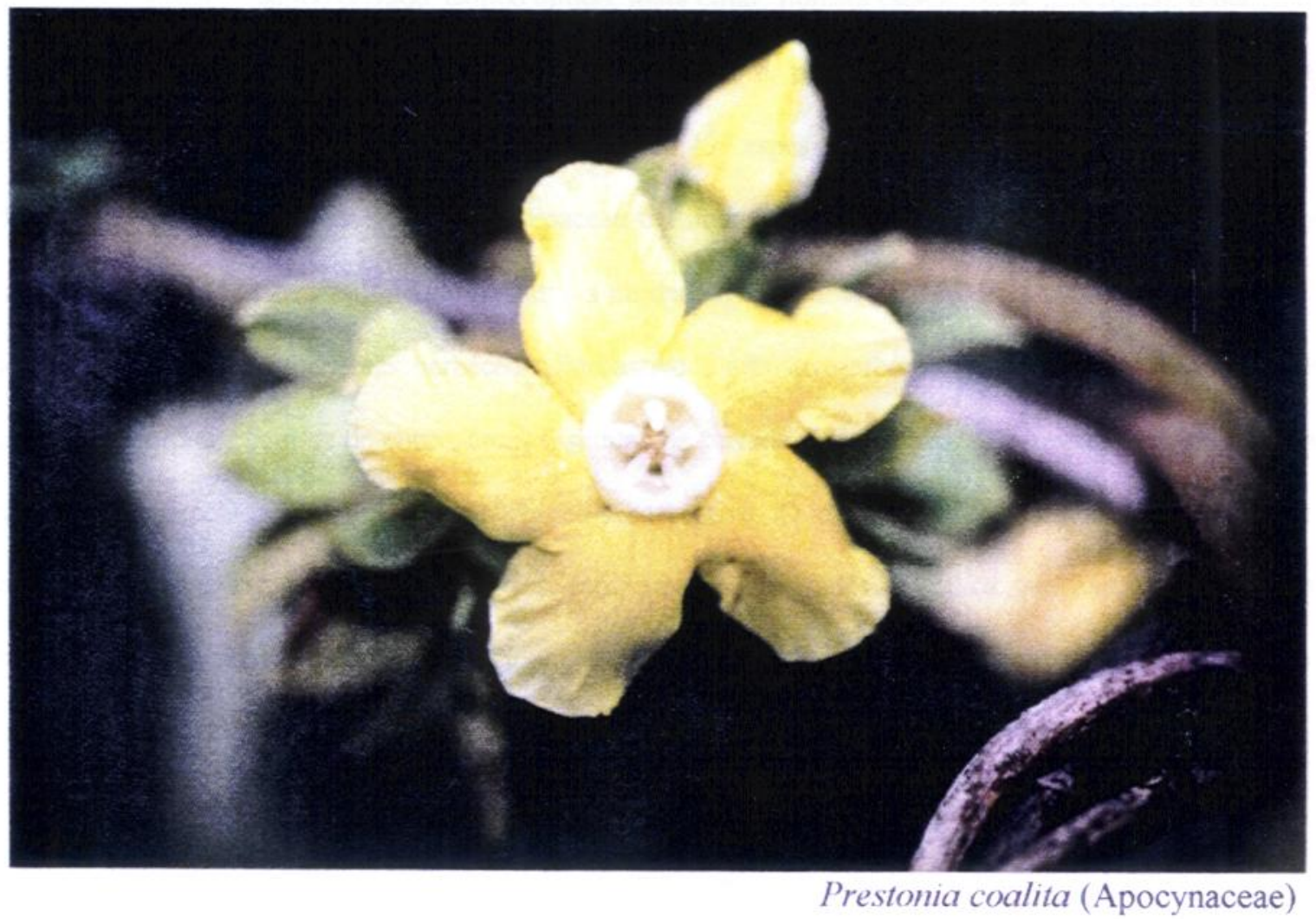




\section{Florística da ARIE Cerrado Pé-de-Gigante (Santa Rita do Passa Quatro, SP).}

Resumo - No presente trabalho, estudou-se uma área de vegetação natural, composta principalmente por cerrado, de 1269ha, situada no munícipio de Santa Rita do Passa Quatro, estado de São Paulo (21³6-44’S e 47³4-41'W). O levantamento florístico da área foi efetuado em 18 excursões de coleta mensais, com duração de 3 ou 4 dias cada, entre setembro de 1995 e fevereiro de 1997. Em cada uma das formações e fisionomias de cerrado existentes (cerradão, cerrado "sensu stricto", campo cerrado, campo úmido, mata ciliar, floresta estacional semidecídua), o material em fase florífera e/ou frutífera ou de formação de esporos foi coletado e, posteriormente, prensado e identificado em nível específico. Foram coletadas 1944 exsicatas, representando 499 espécies, 317 gêneros e 107 famílias. As famílias que se destacaram foram: Asteraceae, Fabaceae, Poaceae e Rubiaceae. A comparação das formações e fisionomias de cerrado através de índice de similaridade ressaltou a unidade florística do cerrado. Para o cerrado "sensu lato", a flora como um todo e seus componentes herbáceo-subarbustivo e arbustivo-arbóreo foram analisados, comparando-se os resultados encontrados com os de outras áreas disjuntas de cerrado. Esta comparação ressaltou a heterogeneidade do cerrado, principalmente do componente herbáceo-subarbustivo. O campo úmido, com alta porporção de plantas ruderais, e a mata ciliar, com poucas espécies, refletiram as atividades antrópica que foram desenvolvidas nestas formações há pouco tempo. A floresta estacional semidecídua conteve espécies encontradas no cerradão, mostrando que áreas de florestas estacionais podem conter espécies da fisionomia florestal do cerrado.

Palavras-chave: cerrado, savana, florística, fisionomia, Pé-de-Gigante

Abstract - A natural vegetation area, composed mainly by cerrado, with 1269 ha, located at Santa Rita do Passa Quatro municipality, São Paulo State, southeastern Brazil (21³6-44’S e 47³4-41’W), was studied. A floristic survey was carried out in 18 field trips, each one with 3 or 4 days, from September 1995 to February 1997. On each existing vegetation types (three cerrado physiognomies, floodplain grassland, gallery forest and seasonal semidecidous forest) all vascular plants in reproductive stage were collected and then pressed and identified in species level. A total of 499 species, representing 317 genera and 107 families, was found. The most important families were: Asteraceae, Fabaceae, Poaceae and Rubiaceae. The comparison of all vegetation types and cerrado physiognomies through similarity index emphasized the cerrado floristic unity. To the cerrado "sensu lato", the flora as a whole and its two components, woody and herbaceous, were analysed, comparing the results with those obtained from others disjunct cerrado areas. This 
comparison showed the cerrado heterogeneity, due specially to its herbaecous component. The floodplain grassland, with a high proportion of invading species, and the gallery forest, with few species, reflected the human activities carried out on these vegetation types in recent past. Some species found in cerradão were also found in seasonal semidecidous forest, showing that seasonal forest areas can contain species from the cerrado florestal physiognomy.

Key words: cerrado, savanna, floristics, physiognomy, southeastern Brazil

\section{Introdução}

Originalmente, cerca de $23 \%$ do território brasileiro, aproximadamente dois milhões de quilômetros quadrados, eram ocupados por cerrado (Ratter 1992). Este tipo de bioma é encontrado principalmente em Minas Gerais, Mato Grosso, Mato Grosso do Sul, Goiás e Tocantins (Mantovani \& Martins 1993). Áreas restritas de cerrado ainda aparecem nos estados do Amazonas (Ducke \& Black 1954), Amapá (Azevedo 1967), Roraima (Rodrigues 1971, Takeuchi 1960), Alagoas, Bahia, Paraíba e Pernambuco (Rizzini 1979, Veloso 1964), São Paulo (Borgonovi \& Chiarini 1965, Eiten 1970, Löfgren 1896, Troppmair 1974) e Paraná (Ferri 1960, Stellfield 1950).

A vegetação de cerrado se caracteriza por sua grande variação fisionômica. De acordo com Coutinho (1978), o cerrado apresenta fisionomias que vão desde o campo limpo, em que predomina o componente herbáceo, até o cerradão, em que o componente arbóreo é dominante. As fisionomias intermediárias (campo sujo, campo cerrado e cerrado "sensu stricto") são consideradas ecótonos das fisionomias extremas.

Acompanhando a variação fisionômica, a vegetação do cerrado apresenta grande riqueza florística. Baseando-se em amostras de diversas áreas do Brasil central, Rizzini (1963) elaborou uma lista com 537 espécies que ocorriam no componente arbóreo-arbustivo. Alguns anos mais tarde (Rizzini 1971), este autor elaborou uma nova lista, desta vez para o cerrado em geral, em que 
relacionou 648 espécies de árvores e arbustos. Heringer et al. (1976) listaram 774 espécies no componente arbustivo-arbóreo do cerrado. Leitão Filho (1992) relacionou, apenas para o estado de São Paulo, 266 espécies arbóreas. Castro (1994) compilou vários levantamentos florísticos e fitossociológicos realizados em áreas de cerrado, estimando o número de espécies nesta formação entre 5000 e 7000 para seus componentes herbáceo-subarbustivo e arbustivo-arbóreo.

O primeiro levantamento florístico no cerrado foi feito por Warming (1892), em Lagoa Santa, MG. Desde então, diversos levantamentos foram realizados nesta vegetação: Eiten (1963), em Mogi Guaçu; Goodland (1969), no Triângulo Mineiro; Oliveira e Souza (1977), em Itirapina; SilberbauerGottsberger et al. (1977), em Botucatu; Ratter (1980), em Brasília; Mantovani (1983), em Mogi Guaçu; Toledo Filho et al. (1984), em Mogi Mirim; Pagano et al. (1989a), em Corumbataí; Felfili et al. (1994), na Chapada Pratinha; e Batalha et al. (no prelo), em Pirassununga.

Análises florísticas e fitossociológicas foram feitas por Picollo et al. (1971), em Corumbataí; Oliveira e Souza (1977), em Itirapina; Oliveira Filho (1984), na Chapada dos Guimarães; Toledo Filho (1984), em Luiz Antônio; Ribeiro et al. (1985), em Planaltina; Castro (1987), em Santa Rita do Passa Quatro; Mantovani (1987), em Mogi Guaçu e Itirapina; Gianotti (1988), em Itirapina; Pagano et al. (1989b), em Corumbataí; Cavassan (1990), em Bauru; Meira-Neto (1991), em Águas de Santa Bárbara; Nascimento \& Saddi (1992), em Cuiabá; Vincent et al. (1992), em Pirassununga; e Felfili et al. (1994), na Chapada Pratinha.

Este trabalho tem como objetivo realizar um levantamento florístico da ARIE Cerrado Pé-deGigante, distinguindo as diferentes formações e fisionomias. Com isto, espera-se contribuir para estudos fitogeográficos sobre o cerrado e fornecer subsídios ao plano de manejo da área estudada, permitindo seu zoneamento, a compreensão de sua dinâmica e de suas interrelações locais e regionais. 


\section{Material e métodos}

\section{Área de estudo}

A Área de Relevante Interesse Ecólogico (ARIE) Cerrado Pé-de-Gigante está localizada no município de Santa Rita do Passa Quatro, estado de São Paulo, entre as coordenadas 21³6-44’S e 47³4-41'W, sob clima Cwag' de Köppen, em cotas altimétricas de 660 a 730m e sobre latossolo Vermelho-Amarelo fase arenosa (Castro 1987). A área estudada possui 1269ha, dos quais 1060ha constituem a ARIE Cerrado Pé-de-Gigante. Em seu interior, existem variações fisionômicas de cerrado que vão desde o campo sujo ao cerradão, além de mata ciliar, floresta estacional semidecídua e campo de várzea. Para uma caracterização mais detalhada da área, ver o Capítulo 1.

\section{Metodologia}

Em cada uma das formações e fisionomias de cerrado existentes na reserva (cerradão, cerrado "sensu stricto", campo cerrado, campo úmido, mata ciliar e floresta estacional semidecídua), com exceção do campo sujo devido à pequena dimensão, realizou-se, durante um ano e meio, um levantamento florístico em excursões de coletas mensais, com duração de três ou quatro dias cada. O esforço amostral em cada uma das fisionomias foi proporcional à sua extensão.

O material botânico fértil foi coletado em caminhadas assistemáticas. Os espécimes mais frágeis foram prensados imediatamente, enquanto os mais resistentes foram acondicionados em sacos plásticos para posterior prensagem. Durante as coletas, foram anotadas informações como: a altura do indivíduo; cor das pétalas, sépalas e brácteas; as características do sistema subterrâneo; odor das folhas; presença de látex e o hábito de crescimento. Tais informações foram incluídas nos rótulos 
das exsicatas.

Após sua secagem em estufa, o material amostrado foi identificado em nível específico através de bibliografia pertinente e por comparações com exsicatas depositadas em herbário. O material montado foi depositado no herbário do Instituto de Botânica da Secretaria do Meio Ambiente do Estado de São Paulo (SP), com duplicatas nos herbários do Instituto Florestal (SPSF) e do Departamento de Botânica do Instituto de Biociências da Universidade de São Paulo (SPF).

As pteridófitas foram classificadas de acordo com Tryon \& Tryon (1982), enquanto que as angiospermas foram incluídas em famílias segundo o sistema de Cronquist (1988). As espécies foram classificadas em formas de vida segundo o sistema de Raunkiaer (1934), adaptado por Mueller-Dombois \& Ellenberg (1974). A classificação das síndromes de dispersão dos diásporos foi efetuada de acordo com Pijl (1972). Foram consideradas como pertencentes ao componente herbáceo-subarbustivo as espécies caméfitas, epífitas, hemicriptófitas, geófitas, terófitas, lianas, semi-parasitas e parasitas vasculares, e ao componente arbustivo-arbóreo, as fanerófitas.

Foi calculada a similaridade florística em nível específico entre as diferentes formações e fisionomias de cerrado, utilizando-se o índice de Sørensen (Magurran 1988), agrupado pela média de grupo (UPGMA). Da mesma forma, os resultados aqui obtidos foram comparados com outros levantamentos florísticos em que foram utilizadas metodologias semelhantes (Mantovani \& Martins 1993, Batalha et al. no prelo).

As informações quanto às formas de vida e à fenologia, para as fisionomias de cerrado, serão analisadas no Capítulo 5.

\section{Resultados e discussão}

Foram coletadas 1944 exsicatas, que representaram 499 espécies, distribuídas em 317 gêneros e 
107 famílias (Tabela 2.1). Estes números podem ser aumentados, principalmente devido a espécies herbáceas, muitas vezes raras, de pequeno porte e com ciclo epígeo de poucas semanas.

As famílias mais representadas na reserva foram, pela ordem: Asteraceae, Fabaceae, Poaceae, Rubiaceae, Bignoniaceae, Myrtaceae, Apocynaceae, Caesalpiniaceae, Euphorbiaceae, Malpighiaceae, Mimosaceae, Melastomataceae, Sapindaceae, Cyperaceae e Verbenaceae, compreendendo 59,72\% das espécies amostradas (Figura 2.1). Os números de famílias, gêneros e espécies encontrados em cada fisionomia estão representados na Tabela 2.2. Eventualmente, o número total de espécies pode ser maior do que a soma das espécies herbáceo-subarbustivas e das arbustivo-arbóreas, pois algumas espécies foram incluídas nos dois componentes.

As três fisionomias de cerrado foram as únicas consideradas similares pelo índice de Sørensen (Tabela 2.3 e Figura 2.2). O cerrado "sensu stricto" e o campo cerrado foram as fisionomias mais similares $(0,802)$. O cerradão apresentou maiores índices de similaridade com o cerrado "sensu stricto" $(0,592)$ e, depois, com o campo cerrado $(0,520)$. Estes valores reforçam a unidade florística do cerrado, com suas duas floras, a campestre e a florestal (Coutinho 1978).

O campo úmido, por sua vez, embora não podendo ser considerado similar com nenhuma outra fisionomia, mostrou conter mais espécies em comum ao campo cerrado $(0,412)$ e ao cerrado "sensu stricto" (0,318), devido ao componente herbáceo. A mata ciliar foi a formação mais distinta floristicamente das demais, com valores sempre abaixo de 0,13 , por sua baixa riqueza e composição florística. A floresta estacional semidecídua, por último, apresentou espécies em comum ao cerradão $(0,266)$, visto que existem algumas espécies do componente arbóreo que ocorrem em ambas as formações. 
Tabela 2.1 - Lista de espécies amostradas no levantamento florístico da ARIE Cerrado Pé-de-Gigante, Santa Rita do Passa Quatro, SP (47³4-41'W e 21³6-44'S). Legenda: forma de vida - CAM = caméfita, CAM-FAN = caméfita ou fanerófita, EPI = epífita, FAN = fanerófita, GEO = geófita, HEM = hemicriptófita, LIA = liana, PAR = parasita vascular, SPV = semi-parasita vascular, TER = terófita; síndrome de dispersão - ANE $=$ anemocórica, AUT = autocórica, ZOO = zoocórica; síndrome de dispersão - ANE = anemocórica, AUT = autocórica e ZOO = zoocórica; fisionomias - 1 = cerradão, 2 = cerrado "sensu stricto", 3 = campo cerrado, 4 = campo úmido, 5 = mata ciliar, $6=$ floresta estacional semidecídua; período de formação de esporos ou de floração $-1=$ janeiro, 2 = fevereiro, $\ldots, 11=$ novembro e 12 = dezembro; período de frutificação -1 = janeiro, 2 = fevereiro, $\ldots, 11=$ novembro e $12=$ dezembro. O hífen ( - ) representa continuidade entre os meses, enquanto a vírgula $\left(\right.$, ) indica interrupção; $\mathrm{n}^{\mathrm{o}}$ do coletor $=$ número do coletor.

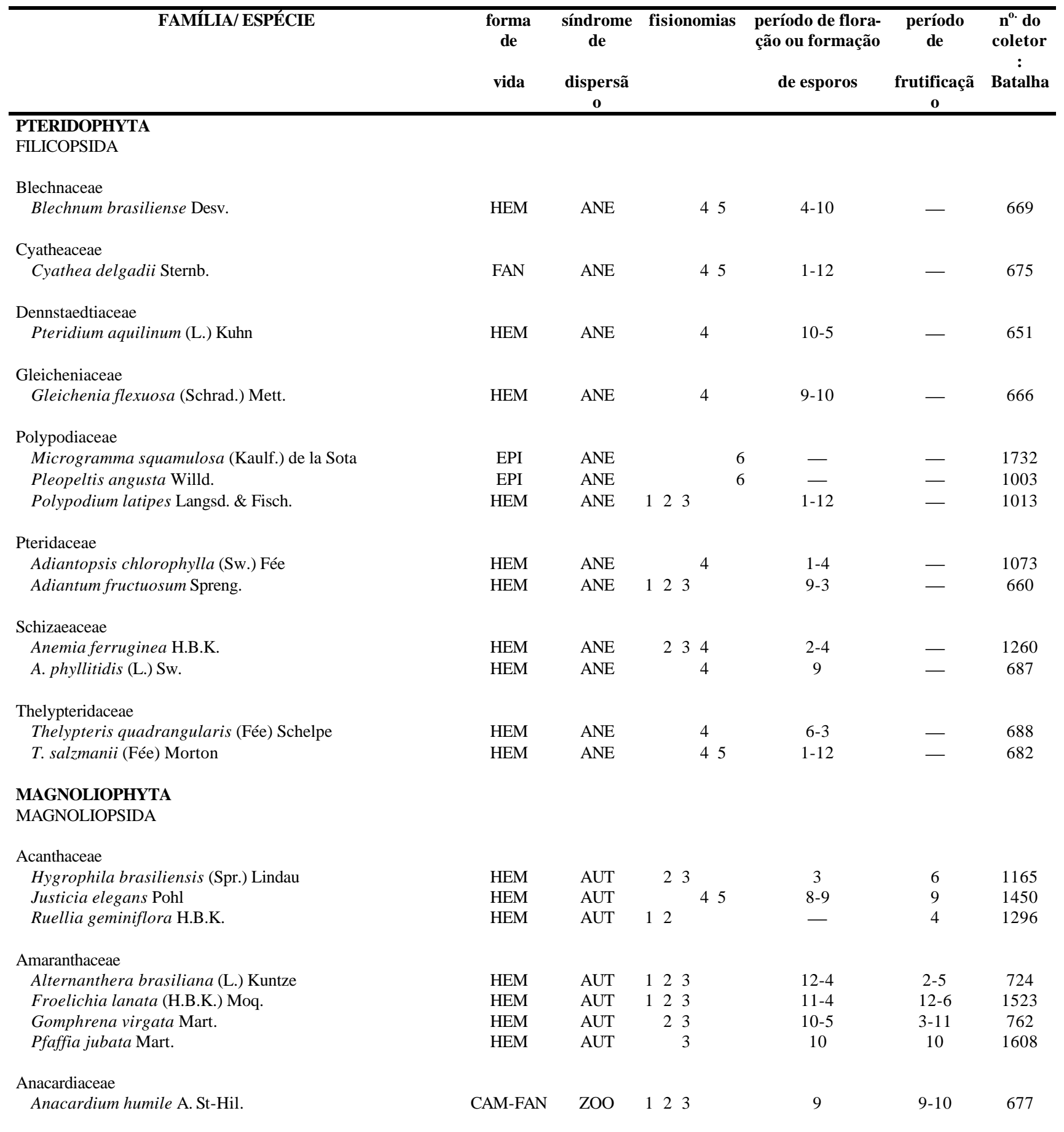


Astronium graveolens Jacq.

Tapirira guianensis Aubl.

Annonaceae

Annona coriacea Mart.

A. crassiflora Mart.

A. dioica A. St-Hil.

Duguetia furfuracea (A. St-Hil.) Benth. \& Hook.

Guatteria australis A. St-Hil.

Xylopia aromatica A. St-Hil.

Apiaceae

Eryngium junceum Cham. \& Schltdl.

Apocynaceae

Aspidosperma cuspa (H.B.K.) S. F. Blake

A. cylindrocarpon Müll. Arg.

A. ramiflorum Müll. Arg.

A. tomentosum Mart.

Forsteronia glabrescens Müll. Arg.

$F$. velloziana (A. DC.) Woods.

Hancornia speciosa Gomez

Himatanthus obovata (Müll. Arg.) Woods.

Mandevilla vellutina (Mart.) Woods.

Mesechites mansoana (A. DC.) Woods.

Odontadenia lutea (Vell.) Markgr.

Prestonia coalita (Vell.) Woods.

P. tomentosa $\mathrm{R}$. Br.

Rhodocalyx rotundifolius Müll. Arg.

Temnadenia violacea (Vell.) Miers

Araliaceae

Didymopanax vinosum (Cham. \& Schltdl.) Seem

Aristolochiaceae

Aristolochia giberti Hook.

Asclepiadaceae

Astephanus carassensis Malme

Blepharodon nitidum (Vell.) J. Macbr.

Ditassa acerosa Mart.

D. nitida Fourn.

Oxypetalum appendiculatum Mart. \& Zucc.

Asteraceae

Acanthospermum australe (Loefl.) Kuntze

Achyrocline satureoides (Lam.) A. DC.

Aspilia reflexa Baker

Baccharidastrum triplinervum (Less.) Cabrera

Baccharis dracunculifolia A. DC.

B. humilis Sch. Bip.

B. rufescens Spreng.

Bidens gardneri Baker

Chaptalia integerrima (Vell.) Burk

Clibadium armani (Balb.) Sch Bip.

Conyza canadensis (L.) Cronquist

Dasyphyllum sprengelianum (Gardner) Cabrera

Elephantopus biflora Less.

E. mollis L.

Emilia coccinea (Simns) Sweet

Erechtites hieracifolia (L.) Raf.

Eremanthus sphaerocephalus Baker

Eupatorium chlorolepsis Baker

E. laevigatum Lam.

E. maximiliani Schrad.

E. squalidum A. DC.

Gochnatia barrosii Cabrera

G. pulchra Cabrera

Kanimia oblongifolia Baker

Mikania cordifolia (L.) Willd.

Orthopappus angustifolius (Sw.) Gleason

$\begin{array}{cccccccccc}\text { FAN } & \text { ANE } & & & & 6 & - & - & 1391 \\ \text { FAN } & \text { ZOO } & 1 & 2 & 3 & 5 & 6 & 9-10 & - & 770 \\ & & & & & & & & & \\ & & & & & & & & & \\ \text { CAM-FAN } & \text { ZOO } & 1 & 2 & 3 & & & 9-12 & 9-12 & 671 \\ \text { FAN } & \text { ZOO } & 1 & 2 & 3 & & & 11-12 & 11-12 & 841 \\ \text { CAM } & \text { ZOO } & & 2 & 3 & & & 11-12 & 1 & 1509 \\ \text { FAN } & \text { ZOO } & 1 & 2 & 3 & & & 11-7 & 1-12 & 1518 \\ \text { FAN } & \text { ZOO } & & & & 6 & - & -12 & 1671 \\ \text { FAN } & \text { ZOO } & 1 & 2 & 3 & & 6 & 1-12 & 1-12 & 775\end{array}$

HEM

AUT

34

$12-1$

4

854

FAN

FAN

ANE

FAN

FAN

LIA

LIA

FAN

FAN

HEM

LIA

LIA

LIA

LIA

HEM

LIA

FAN

ZOO

ANE

ANE

ANE

ANE

ZOO

ANE

ANE

ANE

ANE

ANE

ANE

ANE

ANE

$\begin{array}{llllll}1 & 2 & 3 & & & \\ 2 & 3 & 4 & \\ & & & & \\ & & & & 5 \\ & 2 & & & & \end{array}$

23

2

6

23

4
4

2

1236

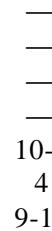

$-$

12-6

12-1

$6-$

$1-9$
2

2

12

10-4

2-11

LIA

ANE

3

2

LIA

ANE

LIA

HEM

LIA

LIA

ANE

ANE

ANE

ANE

2

23

12

2

TER

ZOO
AUT

TER

HEM

HEM

CAM

CAM

CAM

TER

TER

CAM

TER

CAM

HEM

HEM

TER

TER

HEM

HEM

CAM

CAM

TER

CAM

CAM

CAM

LIA

HEM
AUT

ANE

ANE

ANE

ANE

ZOO

ANE

AUT

ANE

ANE

ANE

ANE

ANE

ANE

ANE

ANE

ANE

ANE

ANE

ANE

ANE

ANE

ANE

ANE
3
3

2

4

23

234

23

$\begin{array}{llll}1 & 2 & 3 & 4\end{array}$

$\begin{array}{lll}2 & 3 & 4\end{array}$

4
234

12

34

1234

234

4

23

23

4

1234

$\begin{array}{lll}2 & 3 & 4\end{array}$

$\begin{array}{lll}2 & 3 & 4\end{array}$

$\begin{array}{llll}1 & 2 & 3 & 4\end{array}$

23

$\begin{array}{lll}2 & 3 & 4\end{array}$

$\begin{array}{lll}2 & 3 & 4\end{array}$
4-5

10-2

3-6

4-6

$-$

3-6

11-1

2

12-4

11-4

12-7

3-4

11-2

12-3

6-11

2-5

2-3

11-3

9-3

7

4

-

3-6

8-10

2-8

9-2

12-6

12-3
611

1081

1393
$-\quad 1394$

- 1166

- $\quad 1167$

- $\quad 1582$

9-11 898

- $\quad 1574$

$1 \quad 987$

1432

- 1608

- 1611

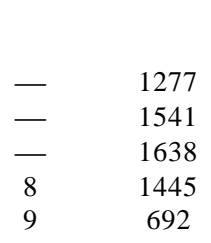

$12 \quad 1540$

4-10 828

11-1 991

$2 \quad 1626$

1-7 1433

11-6 969

$9 \quad 1703$

12-8 1038

3-4 1281

$2 \quad 1603$

12-3 963

6-11 659

5-6 1263

6-9 1606

11-3 1032

1-12 855

7-10 1443

- 1275

$5 \quad 1333$

1-12 902

4-10 618

9-10 1456

6-11 1636

9-2 750

2-10 1599

2-11 1536
- $\quad 891$ 
Piptocarpha rotundifolia (Less.) Baker Porophyllum angustissimum Gardner P. ruderale (Jacq.) Cass.

Pterocaulon rugosum (Vahl) Malme

P. virgatum (L.) A. DC.

Trichogonia salviifolia Gardner

Vanillosmopsis erythropappa Sch. Bip.

Vernonia apiculata Mart.

$V$. bardanoides Less.

V. cephalotes A. DC.

$V$. ferruginea Less.

V. herbacea (Vell.) Rusby

$V$. holosericea Mart.

V. lappoides Baker

$V$. obtusata Less.

V. onopordioides Baker

V. petiolaris A. DC.

$V$. polyanthes (Spr.) Less.

V. radula Mart.

V. rubriramea Mart.

V. scabra Pers.

V. scorpioides (Lam.) Pers.

Viguiera discolor Baker

Wulffia stenoglossa A. DC.

\begin{tabular}{|c|c|c|c|c|c|c|c|}
\hline FAN & ANE & & 3 & & $12-4$ & $1-12$ & 1025 \\
\hline TER & ANE & & 3 & & $4-6$ & $6-9$ & 1362 \\
\hline TER & ANE & & 3 & & 3 & 3 & 1631 \\
\hline HEM & ANE & & 3 & & $3-4$ & $3-4$ & 1130 \\
\hline HEM & ANE & & 2 & 4 & - & 5 & 1339 \\
\hline HEM & ANE & 2 & 32 & 45 & $12-8$ & $12-8$ & 1045 \\
\hline FAN & ANE & & 3 & & $5-7$ & 7-9 & 1341 \\
\hline HEM & ANE & & 32 & 4 & $2-4$ & 4,10 & 1293 \\
\hline HEM & ANE & 12 & 3 & & $2-6$ & $2-10$ & 666 \\
\hline HEM & ANE & 2 & & & 8 & - & 1446 \\
\hline CAM & ANE & 2 & & & 7 & - & 1412 \\
\hline HEM & ANE & & 3 & 4 & $1-3$ & $2-4$ & 1291 \\
\hline CAM & ANE & & 3 & & $6-9$ & 9 & 1352 \\
\hline HEM & ANE & & 3 & & $3-4$ & $3-4$ & 1173 \\
\hline CAM & ANE & & 3 & & 6 & $6-7$ & 1375 \\
\hline HEM & ANE & & 3 & & $3-5$ & $3-6$ & 1641 \\
\hline HEM & ANE & & 2 & 4 & 2 & 2 & 1601 \\
\hline CAM & ANE & 2 & 3 & 4 & $10-11$ & $10-7$ & 833 \\
\hline CAM & ANE & & 2 & 4 & $1-3$ & $1-3$ & 1562 \\
\hline CAM & ANE & 2 & 3 & 4 & $1-6$ & $6-10$ & 1282 \\
\hline CAM & ANE & 2 & & & 9 & 7-9 & 1426 \\
\hline HEM & ANE & & & 6 & $5-8$ & $5-8$ & 1436 \\
\hline HEM & AUT & & 3 & & $1-5$ & $2-5$ & 1571 \\
\hline HEM & AUT & 2 & 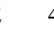 & 4 & $1-5$ & $2-5$ & 1607 \\
\hline HEM & ANE & & & 4 & $9-3$ & $9-3$ & 681 \\
\hline HEM & ANE & 2 & & & - & 10 & 796 \\
\hline LIA & ANE & & 3 & & - & 8 & 1451 \\
\hline CAM & ANE & & 3 & & $10-4$ & 4 & 1005 \\
\hline LIA & ANE & 12 & 3 & & $1-5$ & $4-11$ & 658 \\
\hline LIA & ANE & & 3 & 56 & $12-3$ & 7-9 & 1615 \\
\hline LIA & ANE & & & 6 & - & 7 & 1438 \\
\hline LIA & ANE & 2 & 3 & 6 & $5-6$ & - & 1338 \\
\hline FAN & ANE & 2 & & & - & - & 1175 \\
\hline LIA & ANE & 12 & 3 & & $11-4$ & $1-12$ & 964 \\
\hline LIA & ANE & & & 5 & $6-12$ & $12-2$ & 978 \\
\hline AM-FAN & ANE & 2 & 32 & & $3-10$ & $7-1$ & 1431 \\
\hline CAM & ANE & & 3 & & $10-11$ & - & 751 \\
\hline CAM & ANE & 2 & & & 12 & - & 970 \\
\hline CAM & ANE & 12 & 3 & & $9-3$ & $9-3$ & 975 \\
\hline LIA & ANE & 12 & 3 & 456 & $5-11$ & $7-12$ & 1434 \\
\hline LIA & ANE & & & 5 & 2 & 2 & 1600 \\
\hline FAN & ANE & & 3 & & $9-10$ & - & 1177 \\
\hline FAN & ANE & 12 & 3 & & 9 & - & 933 \\
\hline FAN & ANE & & & 6 & - & - & 1178 \\
\hline FAN & ANE & & 3 & & 4 & - & 1294 \\
\hline FAN & ANE & & & 6 & - & - & 1387 \\
\hline CAM & ANE & & 3 & & 9 & $9-11$ & 645 \\
\hline FAN & ANE & 12 & 3 & & $7-8$ & $9-12$ & 1427 \\
\hline FAN & ANE & 1 & & & - & - & 1288 \\
\hline HEM & $\mathrm{ZOO}$ & & 3 & 4 & 4 & - & 1595 \\
\hline FAN & $\mathrm{ZOO}$ & & & 6 & - & - & 1249 \\
\hline CAM & AUT & & & 4 & $8-9$ & 3,9 & 1179 \\
\hline FAN & $\mathrm{ZOO}$ & 12 & 3 & 6 & $6-8$ & $8-2$ & 1413 \\
\hline EPI & $\mathrm{ZOO}$ & 1 & & & - & 11 & 829 \\
\hline
\end{tabular}

Begoniaceae

Begonia cucullata Willd.

Bignoniaceae

Anemopaegma arvense (Vell.) Stellfeld

A. chamberlaynii (Simns) Bur. \& K. Schum.

Arrabidaea brachypoda (A. DC.) Bur.

A. craterophora (A. DC.) Bur.

A. florida A. DC

A. pulchella (Cham.) Bur.

Cremastus pulcher (Cham.) Bur.

Cybistax antisyphillitica Mart.

Distictella mansoana (A. DC.) Urban

Fridericia speciosa Mart.

Jacaranda caroba (Vell.) A. DC.

J. decurrens Cham.

J. rufa Silva Manso

Memora peregrine (Miers.) Sandwith

Pyrostegia venusta (Ker) Bur.

Stizophyllum perforatum (Cham.) Miers.

Tabebuia aurea (Silva Manso) Benth. \& Hook. f. ex S.

Moore.

T. ochracea (Cham.) Standl.

T. serratifolia (Vahl.) Nicholson

Zeyhera montana Mart.

Z. tuberculosa (Vell.) Bur.

Bixaceae

Cochlospermum regium (Mart.) Pilg.

Bombacaceae

Eriotheca gracilipes (K. Schum.) A. Robyns

Pseudobombax longiflorum (Mart. \& Zucc.) A. Robyns

Boraginaceae

Cordia corymbosa (L.) G. Don.

C. sellowiana Cham.

Buddlejaceae

Buddleja brasiliensis Jacq. ex Spreng.

Burseraceae

Protium heptaphyllum (Aubl.) March

EPI

ZOO 
Caesalpiniaceae

Bauhinia forficata Link

B. rufa Steud.

Chamaechrista campestris Irwin \& Barneby

C. cathartica (Mart.) Irwin \& Barneby

C. debilis (Vogel) Irwin \& Barneby

C. desvauxii (Collad.) Killip

C. flexuosa (L.) Greene

C. rotundifolia (Pers.) Greene

Copaifera langsdorfii Desf.

Dyptichandra aurantiaca Tul.

Hymenaea courbaril L.

H. stigonocarpa Mart.

Sclerolobium paniculatum Benth.

Senna rugosa (G. Don.) Irwin \& Barneby

S. sylvestris (Vell.) Irwin \& Barneby

Campanulaceae

Lobelia exaltata Pohl

Syphocampylus sulfureus E. Winn.

Caryocaraceae

Caryocar brasiliense Cambess.

\begin{tabular}{|c|c|c|c|c|c|c|c|}
\hline FAN & AUT & & & & 6 & $7-8$ & $7-9$ \\
\hline FAN & AUT & 1 & 23 & & & $12-3$ & $1-12$ \\
\hline CAM & AUT & & 3 & 4 & & $1-4$ & $1-4$ \\
\hline CAM & AUT & & 3 & 4 & & $12-6$ & 6 \\
\hline CAM & AUT & & 23 & 4 & & $11-7$ & $1-12$ \\
\hline CAM & AUT & & 23 & 4 & & $1-7$ & $2-7$ \\
\hline CAM & AUT & & 23 & 4 & & $9-4$ & $2-9$ \\
\hline HEM & AUT & & 3 & 4 & & 5 & $5-6$ \\
\hline FAN & $\mathrm{ZOO}$ & 1 & 23 & & 6 & - & $9-6$ \\
\hline FAN & ANE & 1 & 23 & & & $11-12$ & $1-11$ \\
\hline FAN & $\mathrm{ZOO}$ & & & & 6 & - & - \\
\hline FAN & $\mathrm{ZOO}$ & 1 & 23 & & & 1 & $7-10$ \\
\hline FAN & ANE & 1 & 2 & & & - & - \\
\hline FAN & AUT & & 23 & & & $2-6$ & 4-11 \\
\hline FAN & AUT & 1 & 2 & & & $2-3$ & 9 \\
\hline
\end{tabular}

Caryophyllaceae

Polycarpaea corymbosa (L.) Lam.

Cecropiaceae

Cecropia pachystachya Trècul

HE

AUT

$2-5$

3-5 $\quad 1185$

HEM

AUT

9-2

CAM-FAN

ZOO

123

9-11

11-2 771

HEM

AUT

234

12-4

3-6

1511

FAN

ZOO

45

$9-1$

$1-12$

804

Celastraceae

Austroplenckia populnea (Reissek) Lund

FAN

ANE

12

949

Chrysobalanaceae

Couepia grandiflora (Mart. \& Zucc.) Benth.

Licania humilis Cham. \& Schltdl.

Parinari excelsa Sabine

\begin{tabular}{|c|c|c|c|c|}
\hline FAN & $\mathrm{ZOO}$ & 123 & $8-11$ & $10-2$ \\
\hline CAM-FAN & $\mathrm{ZOO}$ & 123 & $6-10$ & $10-12$ \\
\hline CAM & $\mathrm{ZOO}$ & 123 & $9-12$ & $9-12$ \\
\hline
\end{tabular}

Clusiaceae

Kielmeyera coriacea Mart.

$K$. rubriflora Cambess.

K. variabilis Mart.

FAN ANE 23

FAN ANE 12

FAN ANE 123

4-6 $\quad-\quad 1736$

Combretaceae

Terminalia brasiliensis Cambess.

FAN

ANE

12-2

5-11

1017

Connaraceae

Connarus suberosus Planch.

Rourea induta Planch.

FAN

$\begin{array}{lllll} & \text { ZOO } & 1 & 2 & 3\end{array}$

$56-$

1320

Convolvulaceae

Ipomoea cairica (L.) Sweet

I. procurrens C.F.W. Meissn.

Jacquemontia tamnifolia (L.) Griseb.

LIA

ZOO 1223

$\overline{8-12}$

931

Cucurbitaceae

Cayaponia espelina (Cogn.) Silva Manso

Dilleniaceae

Davilla elliptica A. St-Hil.

D. rugosa A. St-Hil.

LIA

LIA

ANE
AUT

AUT

23

6

-

- $\quad 1002$

LIA

ZOO

234

11

12-2

1484

FAN

AUT

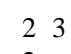

4-6

6-1

4,11

760

LIA AUT 2

4

993

Ebenaceae

Diospyros hispida A. DC.

FAN

$\mathrm{ZOO}$

123

11-2

1479

Ericaceae

Gaylussacia brasiliensis C.F.W. Meissn.

HE

AUT

$10-11$

11

988

Erythroxylaceae

Erythroxylum campestre A. St-Hil

E. cuneifolium (Mart.) O.E. Schulz

FAN

$\mathrm{ZOO}$

$\begin{array}{lll}1 & 2 & 3\end{array}$

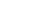

10

10-2

10-11

951

FAN

ZOO 12

E. suberosum A. St-Hil.

FAN

$\mathrm{ZOO}$

23

$9-11$

10-2

1190 
Euphorbiaceae

Actinostemon communis Müll. Arg.

FAN

Croton eriocladus Müll. Arg.

C. floribundus Spreng.

C. glandulosus Müll. Arg.

C. pohlianus Müll. Arg.

C. sclerocalyx Müll. Arg.

C. urucurana Baill.

Hyeronima alchorneoides Allen

Manihot caerulescens Pohl

M. tripartita Müll. Arg.

Pera glabrata (Schott) Baill.

Phyllanthus orbiculatus Müll. Arg.

Sapium glandulatum (Vell.) Pax

Sebastiania bidentata (Mart.) Pax

S. serrulata Müll. Arg.

Fabaceae

Flacourtiaceae

Gesneriaceae

Hippocrateaceae

Peritassa campestris (Cambess.) A.C. Sm.

234

6

9
$12-5$

3

3

HEM

FAN

FAN

HEM

HEM

FAN

TER

CAM

HEM

TER

$\begin{array}{lll}2 & 3 & 4\end{array}$
Acosmium dasycarpum (Vogel) Yakovlev

A. subelegans (Mohl) Yakovlev

Aeschynomene marginata Benth.

Andira anthelmia (Vell.) J. Macbr.

A. cuiabensis Benth.

A. laurifolia Benth.

Bowdichia virgilioides H.B.K.

Centrosema venosum Mart.

Clitoria falcata Lam.

C. laurifolia Poir.

Crotalaria vitellina Ker Gawl.

Dalbergia frutescens (Vell.) Britton

D. miscolobium Benth.

Deguelia nitidula (Benth.) Az.-Tozzi

Desmodium barbatum (L.) Benth.

D. pachyrrizum Vogel

Eriosema crinitum (H.B.K.) Gardner

Galactia decumbens (Benth.) Hassl.

G. grewiifolia (Benth.) Taub.

Indigofera suffruticosa Mill.

Machaerium aculeatum Raddi.

M. acutifolium Vogel

M. stipitatum Vogel

M. villosum Vogel

Macroptilium gracile (Benth.) Urban

Periandra mediterranea (Vell.) Taub.

Platyciamus regnellii Benth.

Platypodium elegans Vogel

Pterodon pubescens Benth.

Rhynchosia melanocarpa Grear

Stylosanthes gracilis H.B.K

S. guianensis Sw.

Vatairea macrocarpa (Benth.) Ducke

Zornia latifolia Sm.

Casearia grandiflora Cambess.

C. sylvestris $\mathrm{Sw}$.

Sinningia sceptrum (Mart.) Wiehler

Tontelea micrantha (Mart.) A.C. Sm.

Lacistemaceae

Lacistema floribundum Miq.

FAN

$\mathrm{ZOO}$

FAN

FAN

HEM

FAN

FAN

CAM

FAN

LIA

LIA

HEM

HEM

FAN

FAN

LIA

HEM

HEM

HEM

HEM

HEM

HEM

FAN

FAN

FAN

FAN

LIA

HEM

FAN

FAN

FAN

LIA

HEM

TER

FAN

HEM

FAN

FAN

$\mathrm{ZOO}$

HEM

ANE

FAN

ZOO

23

2

HEM

$\begin{array}{llllllll}\text { ANE } & 1 & & & & & \\ \text { ANE } & & 2 & & & & \\ \text { ZOO } & & 2 & 3 & 4 & & \\ \text { ZOO } & & 2 & & & 5 & \\ \text { ZOO } & & & & & 6 \\ \text { ZOO } & & 2 & 3 & & & \end{array}$

ANE

AUT

ZOO

AUT

AUT

ANE

ANE

AUT

ZOO

ZOO
AUT

AUT

AUT

AUT

ANE

ANE

ANE

AUT

AUT

ANE

ANE 1

ANE

ZOO

AUT

AUT

$\mathrm{ZOO}$

12

3

3

34

234

123

2

4

23

3

123

2

123

12

123

12

$\begin{array}{ll}2 & 3 \\ 2 & 3\end{array}$

2

123

234

$\mathrm{ZOO}$

12

23

6
6

7-10

11
$10-6$

9

$-$

9-10

8-10

3

2-3

11

1-3

-

9-2

5-7

2

12

-

10-4

-

9-10

-

3-6

3-6

12

9-10

1-3

10-7

-

6-2

11-2

11-2

1072

Lamiaceae

Hyptis brevipes Poit.

AUT

3

7-9

9-12

$11 \quad 1444$

- 1097

397 
H. cana Pohl ex Benth.

H. eriophylla Pohl

H. marruboides Epling

H. mutabilis (A. Rich.) Briq.

H. reticulata Mart.

H. rugosa Benth.

Peltodon tomentosus Pohl

Lauraceae

Cassytha americana Nees

Nectandra megapotamica (Spr.) Mez

Ocotea corymbosa (Meiss.) Mez

O. pulchella Mart.

\section{Loganiaceae}

Strychnos bicolor Progel

S. pseudoquina A. St-Hil.

Loranthaceae

Psittacanthus robustus Mart.

Lythraceae

Cuphea calophylla Cham. \& Schltdl.

C. carthaginensis (Jacq.) Macbr.

Diplusodon virgatus Pohl

Lafoensia pacari A. St-Hil.

\section{Malpighiaceae}

Banisteriopsis argyrophylla (A. Juss.) B. Gates

B. campestris (A. Juss.) Little

B. laevifolia (A. Juss.) B. Gates

B. pubipetala (A. Juss.) Cuatrec.

B. stellaris (Griseb.) B. Gates

B. variabilis $\mathrm{B}$. Gates

Byrsonima coccolobifolia A. Juss.

B. crassa Nied.

B. intermedia A. Juss.

B. verbascifolia (L.) Rich ex A. Juss.

Heteropteris byrsonimifolia A. Juss.

H. umbellata A. Juss.

Mascagnia cordifolia (A. Juss.) Griseb.

Peixotoa tomentosa A. Juss.

Tetrapteris guilleminiana A. Juss.

Malvaceae

P. hexaphylla (S. Moore) Krapov.

Peltaea edouardii (Hochr.) Krapov. \& Cristóbal

Sida glaziovii K. Schum.

S. linifolia A. Juss.

S. rhombifolia $\mathrm{L}$.

S. urens $\mathrm{L}$

Wissadula subpeltata (Kuntze) Fr.

Melastomataceae

Acisanthera alsinaefolia Triana

Miconia albicans Triana

M.chamissois Naudin

M. fallax A. DC.

M. rubiginosa (Bonpl.) A. DC.

M. stenostachya A. DC.

Tibouchina chamissoana Cogn.

T. gracilis (Bonpl.) Cogn.

T. stenocarpa (A. DC.) Cogn.

Meliaceae

Cedrela fissilis Vell.

Trichilia hirta L.

$\begin{array}{ccccccc}\text { HEM } & \text { AUT } & 2 & 9 & 9 & 657 \\ \text { TER } & \text { AUT } & 2 & 3 & 5-8 & 6-9 & 1640 \\ \text { HEM } & \text { AUT } & & 4 & - & 2 & 1627 \\ \text { TER } & \text { AUT } & 2 & & - & 5 & 1316 \\ \text { HEM } & \text { AUT } & 2 & 3 & 1-12 & 1-12 & 747 \\ \text { HEM } & \text { AUT } & 2 & 3 & 2-9 & 3-10 & 1356 \\ \text { HEM } & \text { AUT } & 2 & 3 & 12-6 & 2-9 & 1534\end{array}$

$\begin{array}{llllll}\text { PAR } & \mathrm{ZOO} & 2 & - & 8 & 1462\end{array}$

FAN ZOO $\quad 6 \quad-1696$

$\begin{array}{lllllllll}\text { FAN } & \text { ZOO } & 1 & 2 & 3 & 6 & 11-12 & 3-4 & 600\end{array}$

$\begin{array}{llllll}\text { FAN } & \text { ZOO } & 2 & 3 & 1-4 & 2-7\end{array}$

$\begin{array}{llllllll}\text { LIA } & \text { ZOO } & 1 & 2 & 6 & 11-2 & 11-5 & 1585\end{array}$

$\begin{array}{llllll}\text { FAN } & \text { ZOO } & 1 & 10 & - & 743\end{array}$

$\begin{array}{llllll}\text { SPV } & \text { ZOO } & 2 & 12-2 & 10 & 710\end{array}$

$\begin{array}{llrrrr}\text { CAM } & \text { AUT } & 45 & 5-6 & 6 & 1539\end{array}$

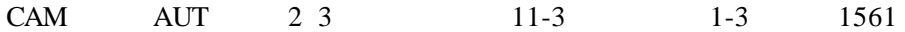

$\begin{array}{llrrrr}\text { CAM AUT } & 4 & 3-4 & 5 & 1617\end{array}$

$\begin{array}{llllll}\text { FAN } & \text { AUT } & 2 & 3 & 4 & -\end{array}$

$\begin{array}{llllllll}\mathrm{LIA} & \mathrm{ANE} & 1 & 4 & 6 & 4-5 & - & 1287\end{array}$

LIA $\quad$ ANE $23 \quad 1-6 \quad 2-10 \quad 1210$

$\begin{array}{llllll}\text { LIA } & \text { ANE } & 2 & 12-5 & 5-9 & 1560\end{array}$

$\begin{array}{lllllll}\text { LIA } & \text { ANE } & 1 & 2 & 3 & 7-1 & 9-1\end{array}$

$\begin{array}{llllllll}\text { LIA } & \text { ANE } & 1 & 2 & 3 & 12-7 & 2-7 & 1024\end{array}$

$\begin{array}{lllllll}\text { LIA } & \text { ANE } & 1 & 2 & 3 & 9 & 9-11\end{array}$

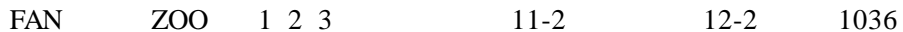

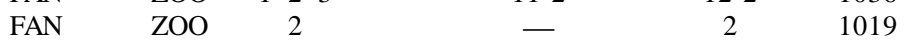

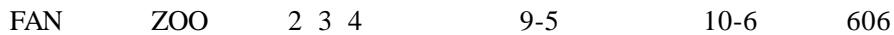

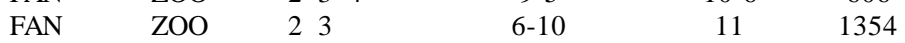

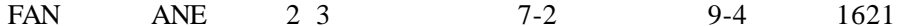

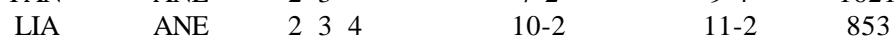

$\begin{array}{lllllllll}\text { LIA } & \text { ANE } & 1 & 2 & 3 & 4 & - & 10-11 & 1494\end{array}$

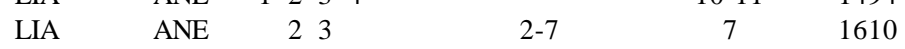

$\begin{array}{llllll}\text { LIA } & \text { ANE } & 6 & 7 & 7 & 1440\end{array}$
2

$1-3$

9

$2-5$

$1-3$

3

6

12-6

9-11

4-11

3-6

2-10

11-6

7-2

9-10

-

2-9

$\begin{array}{lc}6 & 11 \\ 6 & 5\end{array}$
Pavonia communis A. St-Hil.

Leandra lacunosa Cogn.

M. ligustroides Naudin

CAM AUT

CAM AUT

HEM AUT

CAM AUT

TER AUT

TER AUT

HEM AUT

HEM AUT

3

234

3

34

234

3

3

FAN ANE

ANE

FAN ZOO

CAM $Z$

FAN ZOO

ZOO

FAN $\quad$ ZOO

$\begin{array}{ll}\text { FAN } & \text { ANE } \\ \text { CAM } & \end{array}$

CAM ANE

FAN ANE

$\begin{array}{lllll}\text { ANE } & & & & \\ \text { ANE } & 1 & 2 & 3 & 4\end{array}$

FAN

ANE

FAN ZOO
4

123

$123^{4}$

$\begin{array}{lll}1 & 2 & 3\end{array}$

123

123

4
1038

1024

1056

634

1624

1051

1644

1312

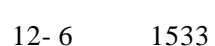

11-7 620

6-1 1629

7-8 1372

9-2 1575

$1-7 \quad 1639$

9-6 1522

$11 \quad 732$

$8 \quad 1461$

$2-7 \quad 1068$

5-10 662

Menispermaceae 
Cissampelos glaberrima A. St-Hil.

C. ovalifolia Ruiz \& Pav.

Mimosaceae

Acacia paniculata Willd.

A. polyphylla A. DC.

Anadenanthera falcata (Benth.) Speg.

A. macrocarpa (Benth.) Brenan

A. peregrina (L.) Speg.

Dimorphandra mollis Benth.

Enterolobium gummiferum (Mart.) Macbr.

Inga uruguensis Hook. \& Arn.

Mimosa debilis Humb. \& Bonpl.

M. gracilis Benth.

$M$. pigra $\mathrm{L}$.

M. xanthocentra Mart.

Plathymenia reticulata Benth.

Stryphnodendron adstringens (Mart.) Coville

S. polyphyllum Benth.

Monimiaceae
Siparuna apiosyce (Mart.) A. DC.
S. guianensis Aubl.

Moraceae

Brosimum gaudichaudii Trècul

Ficus citrifolia Mill.

Myristicaceae

Virola sebifera Aubl.

Myrtaceae

Campomanesia guazumifolia (Cambess.) O. Berg

C. pubescens (A. DC.) O. Berg

Eugenia aurata $\mathrm{O}$. Berg

E. bimarginata A. DC.

E. florida A. DC

E. hiemalis Cambess.

E. langsdorfii O. Berg

E. livida $\mathrm{O}$. Berg

E. punicifolia (Kunth) A. DC.

Myrcia bella Cambess.

M. guianensis (Aubl.) A. DC.

M. lasiantha A. DC.

$M$. lingua $\mathrm{O}$. Berg

M. pubipetala Miq.

M. tomentosa (Aubl.) A. DC.

M. uberavensis $\mathrm{O}$. Berg

Myrciaria floribunda (West \& Willd.) O. Berg

Psidium australe Cambess.

$P$. cinereum Mart.

Siphoneugenia regnelliana (Kiaesrk.) Mattos

Nyctaginaceae

Guapira noxia (Netto) Lund

G. olfersiana Mart.

G. opposita (Vell.) Reitz.

Neea theifera Oerst.

Ochnaceae

Ouratea castaneaefolia (A. DC.) Engl.

O. semiserrata (Mart. \& Nees) Engl.

O. spectabilis (Mart.) Engl.

Onagraceae

Ludwigia nervosa (Poir.) Hara

L. sericea (Cambess.) Hara

Oxalidaceae

Oxalis physocallyx Zucc.

\begin{tabular}{|c|c|c|c|c|c|c|c|}
\hline LIA & AUT & & & 6 & - & - & 996 \\
\hline HEM & AUT & & 23 & & $10-2$ & 2 & 1556 \\
\hline FAN & ANE & & & 5 & $2-3$ & 8 & 1457 \\
\hline FAN & ANE & & & 6 & 2 & $8-9$ & 1590 \\
\hline FAN & AUT & 1 & 23 & 6 & $9-1$ & $1-12$ & 1589 \\
\hline FAN & AUT & & & 6 & - & 10 & 1213 \\
\hline FAN & AUT & & 2 & & 2,9 & 4,12 & 1082 \\
\hline FAN & $\mathrm{ZOO}$ & 1 & 23 & & $12-1$ & $1-9$ & 1706 \\
\hline FAN & AUT & & 2 & & 10 & - & 1470 \\
\hline FAN & $\mathrm{ZOO}$ & & & 5 & - & - & 982 \\
\hline CAM & $\mathrm{ZOO}$ & & 3 & & $1-3$ & $2-5$ & 1616 \\
\hline CAM & ANE & & 23 & & $1-2$ & - & 1016 \\
\hline CAM & $\mathrm{ZOO}$ & & 2 & & 12 & - & 1010 \\
\hline CAM & ANE & & 23 & & $9-2$ & $1-7$ & 1584 \\
\hline FAN & ANE & 1 & 2 & & - & 12 & 1521 \\
\hline FAN & $\mathrm{ZOO}$ & & 23 & & - & - & 1711 \\
\hline FAN & AUT & 1 & 2 & & $12-1$ & 6-12 & 1048 \\
\hline FAN & $\mathrm{ZOO}$ & & & 5 & $5-7$ & $5-7$ & 990 \\
\hline FAN & $\mathrm{ZOO}$ & & 2 & 56 & $7-11$ & - & 1495 \\
\hline FAN & $\mathrm{ZOO}$ & & 2 & & $9-10$ & $9-11$ & 820 \\
\hline FAN & $\mathrm{ZOO}$ & & 2 & & 12 & 12 & 1011 \\
\hline FAN & $\mathrm{ZOO}$ & 1 & 2 & 6 & $1-4$ & $5-11$ & 1576 \\
\hline FAN & $\mathrm{ZOO}$ & & & 6 & - & - & 1713 \\
\hline FAN & $\mathrm{ZOO}$ & & 23 & & $9-11$ & $10-2$ & 1050 \\
\hline FAN & $\mathrm{ZOO}$ & & 23 & & 11 & 3 & 1634 \\
\hline FAN & $\mathrm{ZOO}$ & 1 & 23 & & $5-7$ & $9-12$ & 1455 \\
\hline FAN & $\mathrm{ZOO}$ & & & 6 & 7 & 11 & 1504 \\
\hline FAN & $\mathrm{ZOO}$ & & 2 & 6 & 5 & - & 1314 \\
\hline FAN & $\mathrm{ZOO}$ & 1 & 23 & & 11 & 11 & 1475 \\
\hline FAN & $\mathrm{ZOO}$ & 1 & 23 & & 8 & 12 & 1389 \\
\hline FAN & $\mathrm{ZOO}$ & 1 & 23 & & 1 & $2-4$ & 1222 \\
\hline FAN & $\mathrm{ZOO}$ & 1 & 23 & & $9-12$ & $9-2$ & 965 \\
\hline FAN & $\mathrm{ZOO}$ & & 2 & & - & - & 1220 \\
\hline FAN & $\mathrm{ZOO}$ & 1 & 23 & & $9-11$ & $9-6$ & 754 \\
\hline FAN & $\mathrm{ZOO}$ & 1 & 23 & & $9-12$ & $12-4$ & 1022 \\
\hline FAN & $\mathrm{ZOO}$ & 1 & & 6 & - & - & 1215 \\
\hline FAN & $\mathrm{ZOO}$ & 1 & 2 & 6 & $9-11$ & $11-12$ & 940 \\
\hline FAN & $\mathrm{ZOO}$ & 1 & 23 & & $7-12$ & $10-1$ & 921 \\
\hline FAN & $\mathrm{ZOO}$ & & & 6 & - & - & 1400 \\
\hline CAM & $\mathrm{ZOO}$ & & 23 & & $9-10$ & $11-1$ & 947 \\
\hline CAM & $\mathrm{ZOO}$ & & 23 & & $10-11$ & $10-4$ & 877 \\
\hline FAN & $\mathrm{ZOO}$ & & & 6 & - & - & 1401 \\
\hline FAN & $\mathrm{ZOO}$ & 1 & 2 & & 10 & $10-11$ & 794 \\
\hline FAN & $\mathrm{ZOO}$ & & & 6 & - & - & 1224 \\
\hline FAN & $\mathrm{ZOO}$ & & & 6 & - & - & 932 \\
\hline FAN & $\mathrm{ZOO}$ & & 23 & & - & $11-1$ & 1054 \\
\hline FAN & $\mathrm{ZOO}$ & 1 & & 6 & 9 & - & 1007 \\
\hline FAN & $\mathrm{ZOO}$ & & & 6 & - & - & 1225 \\
\hline FAN & $\mathrm{ZOO}$ & 1 & 23 & & $6-10$ & $10-1$ & 909 \\
\hline FAN & AUT & & & & $2-9$ & $5-10$ & 789 \\
\hline FAN & AUT & & & & $1-10$ & $4-10$ & 956 \\
\hline $\mathrm{CA}$ & AUT & & 23 & & $11-5$ & $12-5$ & 1517 \\
\hline
\end{tabular}


Passifloraceae

Passiflora miersii Mast.

LIA

$\mathrm{ZOO}$

$2-5$

$2-5$

1614

Piperaceae

Piper gaudichaudianum Kunth

FAN

$\mathrm{ZOO}$

5

$2-6$

6

1593

Polygalaceae

Bredemeyera floribunda Willd.

Securidaca tomentosa A. St-Hil

$\begin{array}{llll}\mathrm{ZOO} & 1 & 2 & 3\end{array}$

1-6

$9-12$

5-10 $\quad 1226$

Polygonaceae

Polygonum acre H.B.K.

$P$. acuminatum Kunth

CAM

ANE

2

$10-12$

1001

Portulacaceae

Portulaca hirsutissima Cambess.

P. mucronata Link

Tallinum paniculatum (Jacq.) Gaertn.

AUT

CAM

AUT
AUT

9-5

9-5

640

HEM

AUT

HEM

AUT

HEM

AUT

23

12

11-2

11-12

11-2

$12-5$

1063

Proteaceae

Roupala montana Aubl.

FAN

ANE

HEM

ANE

123

9

663

Rhamnaceae

Crumenaria polygaloides Reissek

Rhamnidium elaeocarpum Reissek

FA

$\mathrm{ZOO}$

Rosaceae

Prunus sellowii Sm.

Rubus brasiliensis Mart.

FA

Rubiaceae

Alibertia macrophylla K. Schum.

A. sessilis (Vell.) K. Schum.

Amaioua guianensis Aubl.

Borreria verticilata (L.) Mey.

B. warmingii $\mathrm{K}$. Schum.

Chiococca alba (L.) Hitchc.

Coccocypselum lanceolatum (Ruiz \& Pav.) Pers.

Coussarea hydrangeaefolia (Benth.) Benth. \& Hook.

Declieuxia fruticosa (Willd.) Kuntze

Diodia schumanii Standl.

D. teres Walt.

Guettarda viburnoides Cham. \& Schltdl.

Ixora venulosa Benth.

Manettia gracilis Cham. \& Schltdl.

Palicourea coriacea (Cham.) K. Schum.

P. crocea (Sw.) R. \& S

$P$. rigida H.B.K.

Psychotria barbiflora A. DC.

P. capitata Ruiz \& Pav.

P. deflexa A. DC.

P. tricholoba Müll. Arg.

Randia spinosa (Jacq.) K. Schum.

Rudgea viburnoides (Cham.) Benth.

Sabicea brasiliensis Wernham

Tocoyena formosa (Cham. \& Schltdl.) K. Schum.

FAN

$\mathrm{ZOO}$

$\begin{array}{rr}12-2 & 836 \\ - & 1014\end{array}$

11-4 999

FAN

CAM

FAN

HEM

HEM

FAN

HEM

FAN

HEM

TER

TER

FAN

FAN

LIA

CAM

CAM

CAM-FAN

CAM

CAM

CAM

CAM

FAN

FAN

HEM

ZOO

FAN

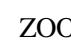

ZOO 1123

$\begin{array}{llll}\mathrm{ZOO} & 1 & 2 & 3 \\ \mathrm{ZOO} & 1 & \end{array}$

AUT 1223

AUT 23

ZOO

$\mathrm{ZOO}$

$\mathrm{ZOO}$

ZOO

AUT

AUT

$\mathrm{ZOO}$

ZOO

ANE

$\mathrm{ZOO}$

$\mathrm{ZOO}$

ZOO

$\mathrm{ZOO}$

$\mathrm{ZOO}$

$\mathrm{ZOO}$

$\mathrm{ZOO}$

$\mathrm{ZOO}$

$\mathrm{ZOO}$

$\mathrm{ZOO}$

FAN

ZOO

FAN

FAN

AUT

Esenbeckia febrifuga (A. St-Hil.) A. Juss. ex Mart.

Zanthoxylum rhoifolium Lam.

FAN ZOO

$\mathrm{ZOO}$

Z. riedelianum Engl.

LIA

Sapindaceae

Cardiospermum grandiflorum $\mathrm{Sw}$.

Cupania oblongifolia Mart.

C. vernalis Cambess.

Magonia pubescens A. St-Hil.

Matayba elaeagnoides Radlk.

Paullinia elegans Cambess.

Serjania erecta Radlk.
FAN

FAN

FAN

FAN

LIA

CAM
ANE

$\mathrm{ZOO}$

ZOO

ANE

ZOO

ANE

ANE
2

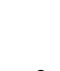

4

$-$

12

- $\quad 986$

1598

12

123

123

2

9

6-9

6

-

$12-1$

1

1-2

3
$12-5$

11-1

$11-1$
6

6

23

56

9-2

123

1

1

6

12

1

3
23

234

11-2

$-$

9-11

12

11-12

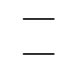

6

11-2

$9 \quad 679$

- 1403

11-12 1087

$10-12 \quad 1360$

2-5 985

$2-4 \quad 1569$

1-2 941

$5 \quad 1315$

3-4 1261

- 1227

12-7 1087

$2-5 \quad 1090$

6-7 1366

- $\quad 1404$

- $\quad 1228$

1596

11-4 1526

1-3 1231

1-6 983

4-6, $12 \quad 1306$

9-5 1468

- 971

4-5 972

- $\quad 1405$

$6,11 \quad 967$

2-7 1515

6-7 1742

1-12 1502

- 1323

- 1381

- 1688

- 1672

- $\quad 1248$

$1-3 \quad 1250$

- 1679

$\begin{array}{ccc}7-10 & - & 864 \\ 11-2 & 11-2 & 1554\end{array}$ 
S. lethalis A. St-Hil.

S. reticulata Cambess.

Talisia angustifolia Raddi

Toulicia tomentosa Radlk.

Sapotaceae

Pouteria ramiflora (Mart.) Radlk.

P. subcaerulea Pierre ex Dubard

P. torta (Mart.) Radlk.

Pradosia brevipes (Pierre) Penn.

Scrophulariaceae

Buchnera lavandulacea Cham. \& Schltdl.

Scoparia dulcis L.

Solanaceae

Cestrum calycinum Willd.

Solanum erianthum D. Don

S. lycocarpum A. St-Hil.

S. palinacanthum Dunal

Sterculiaceae

Byttneria sagittifolia A. St-Hil.

Helicteres brevispira A. St-Hil.

H. sacarolha A. St-Hil.

Melochia spicata (L.) Fryxell

Waltheria americana $\mathrm{L}$.

W. communis L.

Styracaceae

Styrax ferrugineus Nees \& Mart.

Symplocaceae

Symplocos pubescens Klotz

Tiliaceae

Luehea divaricata Mart.

Trigoniaceae

Trigonia nivea Cambess.

Turneraceae

Piriqueta rosea (Cambess.) Urban

Verbenaceae

Aegiphila lhotzkiana Cham.

A. sellowiana Cham.

Aloysia virgata (Ruiz \& Pav.) A. Juss.

Lantana camara L.

L. fucata Lindl.

L. lilacina Desf.

Lippia lasiocalycina Cham.

L. lupulina Cham.

L. salviifolia Cham.

Stachytarpheta maximilliani Schauer

Violaceae

Hybanthus atropurpureus (A. St-Hil.) Taub.

Vitaceae

Cissus erosa Rich.

C. inundata (Baker) Planch.

C. sessilifolia (Baker) Gilg

Vochysiaceae

Qualea dichotoma Warm.

Q. grandiflora Mart.

Q. multiflora Mart.

$Q$. parviflora Mart.

Vochysia cinamommea Pohl

V. tucanorum Mart.

\begin{tabular}{|c|c|c|c|c|c|c|c|}
\hline LIA & ANE & 12 & 23 & & 9 & $9-10$ & 664 \\
\hline LIA & ANE & 12 & 23 & 6 & $2-9$ & $5-10$ & 1329 \\
\hline CAM & $\mathrm{ZOO}$ & 12 & & & $9-11$ & 1 & 914 \\
\hline CAM & ANE & & 23 & & 4-6 & $5-10$ & 693 \\
\hline FAN & $\mathrm{ZOO}$ & 12 & & & $6-9$ & $12-2$ & 1524 \\
\hline CAM & $\mathrm{ZOO}$ & 12 & 23 & & $9-1$ & $12-2$ & 655 \\
\hline FAN & $\mathrm{ZOO}$ & 12 & 23 & & $6-9$ & $9-3$ & 1428 \\
\hline HEM & $\mathrm{ZOO}$ & 12 & 23 & & 10 & - & 887 \\
\hline HEM & ANE & & 3 & & 4 & 4 & 1292 \\
\hline CAM & AUT & & 4 & & 11 & 11 & 958 \\
\hline CAM & $\mathrm{ZOO}$ & & 4 & & $8-2$ & $9-3$ & 1617 \\
\hline CAM & $\mathrm{ZOO}$ & & 234 & & $10-6$ & 12 & 868 \\
\hline CAM & $\mathrm{ZOO}$ & & 234 & & $9-2$ & $1-2$ & 929 \\
\hline TER & $\mathrm{ZOO}$ & & 234 & & $8-1$ & $8-3$ & 656 \\
\hline HEM & AUT & 12 & 23 & & $11-2$ & $2-5$ & 1493 \\
\hline HEM & AUT & & & 6 & $10-11$ & - & 1469 \\
\hline HEM & AUT & & 3 & & 3 & - & 1235 \\
\hline HEM & AUT & & 4 & & 2 & - & 1619 \\
\hline HEM & AUT & & 234 & & $1-10$ & $1-10$ & 835 \\
\hline HEM & AUT & & 23 & & $12-4$ & $2-4$ & 984 \\
\hline FAN & $\mathrm{ZOO}$ & 12 & 23 & & $2-9$ & $7-9$ & 1324 \\
\hline FAN & $\mathrm{ZOO}$ & & & 6 & - & - & 1691 \\
\hline FAN & AUT & 12 & 23 & 6 & $9-10$ & $11-12$ & 582 \\
\hline FAN & AUT & & & 5 & 12 & - & 910 \\
\hline HEM & AUT & & 3 & & $12-1$ & $12-1$ & 1055 \\
\hline FAN & $\mathrm{ZOO}$ & 2 & & & $11-12$ & - & 906 \\
\hline FAN & $\mathrm{ZOO}$ & & & 6 & - & - & 1380 \\
\hline FAN & $\mathrm{ZOO}$ & & & 6 & - & - & 1405 \\
\hline CAM & $\mathrm{ZOO}$ & 12 & 234 & & $12-3$ & $12-3$ & 1597 \\
\hline CAM & $\mathrm{ZOO}$ & 2 & & & 11 & 11 & 939 \\
\hline HEM & $\mathrm{ZOO}$ & & 4 & & 1 & 1 & 1715 \\
\hline CAM & AUT & 2 & & & $10-3$ & $11-3$ & 821 \\
\hline HEM & AUT & 2 & & & $9-11$ & $9-11$ & 870 \\
\hline CAM & AUT & 12 & 23 & & $1-4$ & $5-9$ & 911 \\
\hline HEM & AUT & & 34 & & $12-3$ & $2-3$ & 1548 \\
\hline CAM & AUT & & & 6 & $11-5$ & $11-5$ & 1621 \\
\hline LIA & $\mathrm{ZOO}$ & & 234 & & $12-4$ & $2-4,9$ & 953 \\
\hline LIA & $\mathrm{ZOO}$ & & 234 & & $11-12$ & $11-12$ & 826 \\
\hline LIA & $\mathrm{ZOO}$ & & 234 & & $11-1$ & 2 & 863 \\
\hline FAN & ANE & 12 & 23 & & - & 10 & 729 \\
\hline FAN & ANE & 12 & 23 & 6 & $9-2$ & $5-12$ & 650 \\
\hline FAN & ANE & 12 & & & $12-2$ & - & 981 \\
\hline FAN & ANE & 12 & 23 & & $11-2$ & $9-4$ & 676 \\
\hline FAN & ANE & 12 & 23 & & $2-4$ & $2-12$ & 892 \\
\hline FAN & ANE & 12 & 23 & 56 & $12-2$ & 4 & 819 \\
\hline
\end{tabular}


LILIOPSIDA

Araceae

Philodendron eichleri Engl.

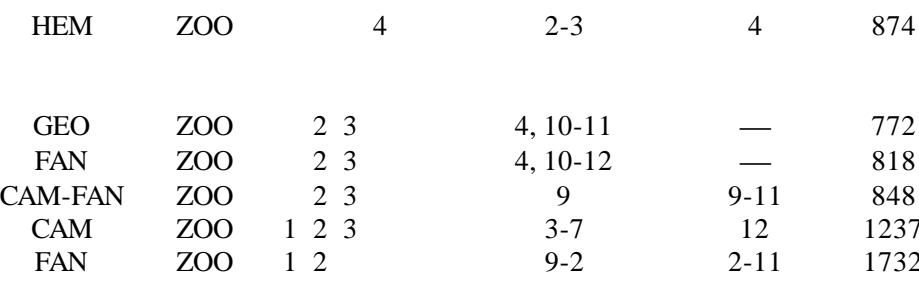

Arecaceae

Attalea geraensis Barb. Rodr.

Butia paraguayensis (Barb. Rodr.) Bailey

Syagrus flexuosa (Mart.) Becc.

S. loefgrenii Glass.

S. romanzoffiana (Cham.) Glass.

$\mathrm{ZOO}-12$

Bromeliaceae

Acanthostachys strobilacea (Schult f.) Klotz

Aechmea bromeliifolia (Rudge) Baker

Ananas ananassoides (Baker) L.B. Sm.

Bromelia balansae $\mathrm{Mez}$

Dickia tuberosa (Vell.) Beer

Tillandsia geminiflora Brogn.

\begin{tabular}{|c|c|c|c|c|c|c|c|c|}
\hline EPI & AUT & & & & 6 & 11 & 5 & 1346 \\
\hline EPI & AUT & 1 & 2 & & & 10 & 11 & 878 \\
\hline HEM & $\mathrm{ZOO}$ & 1 & 23 & 4 & & $9-12$ & $9-5$ & 737 \\
\hline HEM & $\mathrm{ZOO}$ & 1 & $2 ?$ & 4 & & $9-12$ & $9-7$ & 683 \\
\hline HEM & AUT & & 23 & & & 10 & 11 & 788 \\
\hline EPI & AUT & 1 & 2 & & 6 & 11 & $4-5,9$ & 684 \\
\hline TER & AUT & 1 & 23 & 4 & & $9-6$ & $9-6$ & 1476 \\
\hline HEM & AUT & & & 4 & & 2 & 2 & 1100 \\
\hline HEM & $\mathrm{ZOO}$ & & & 4 & & 2 & - & 1583 \\
\hline HEM & AUT & & 23 & 4 & & $9-5$ & $2-7$ & 1416 \\
\hline HEM & AUT & & 23 & 4 & & $12-2$ & $2-6$ & 876 \\
\hline HEM & AUT & & 23 & 4 & & $11-4$ & $1-5$ & 822 \\
\hline HEM & AUT & 1 & 23 & 4 & & $11-5$ & $3-10$ & 1474 \\
\hline HEM & AUT & & & 4 & & $12-2$ & 4 & 882 \\
\hline HEM & AUT & & & 4 & & $9-10$ & $9-10$ & 779 \\
\hline HEM & AUT & & & 4 & & $10-2$ & $12-3$ & 850 \\
\hline HEM & AUT & & & 4 & & $9-12$ & 12 & 884 \\
\hline HEM & AUT & 1 & 23 & & & $5-1$ & $10-7$ & 721 \\
\hline HEM & AUT & 1 & 23 & 4 & & $11-7$ & $12-8$ & 811 \\
\hline
\end{tabular}

Commelinaceae

Commelina erecta $\mathrm{L}$

Dichorisandra hexandra Standl.

Costaceae

Costus arabicus L.

Cyperaceae

Bulbostylis hirtella (Schrad.) Urban

B. sphaerocephala (Boeck.) C.B. Clarke

Cyperus cayennensis (Lam.) Britton

C. diffusus Vahl

C. laetus Kunth

Eleocharis grandis Boeck

Rhynchospora albiceps Kunth

$R$. corymbosa $(\mathrm{L}$.) Britton

R. exaltata Kunth

Scleria comosa (Nees) Steud.

LIA

ANE

46

2

1625

Heliconiaceae

Heliconia hirsuta L. f.

HEM

$\mathrm{ZOO}$

45

$1-12$

$1-12$

1377

Iridaceae

Trimezia juncifolia (Kl.) Kunth

GEO

AUT

3

$2-4,10$

Liliaceae

Alstroemeria pulchella L. f.

HEM

AUT

23

$1-4$

3-4

1255

Marantaceae

Calathea sellowii Körn.

C. zebrina Lund

HEM

$\mathrm{ZOO}$

$\mathrm{ZOO}$

- $\quad 1238$

Orchidaceae

Galeandra montana Barb. Rodr.

Ionopsis paniculata Lindl.

Mesadenella cuspidata (Lindl.) Garay

GEO

ANE

HEM

ANE 1

ANE

Poaceae

Andropogon bicornis $\mathrm{L}$.

A. leucostachys H.B.K.

Aristida jubata (Arechav.) Herter

Axonopus barbigerus (Kunth) Hitchc.

A. marginatus (Trin.) Chase

Brachiaria decumbens Stapf

Chloris barbata (L.) Sw.

Cortaderia selloana (Schult.) Asch. \& Graebn.

Digitaria insularis (L.) Fedde

Echinolaena inflexa (Poir.) Chase

Eragrostis airoides Ness

HEM

HEM

HEM

HEM

HEM

HEM

HEM

HEM

HEM

HEM

HEM
AUT

AUT

ANE

ZOO

$\mathrm{ZOO}$

$\mathrm{ZOO}$

$\mathrm{ZOO}$

ANE

ANE

$\mathrm{ZOO}$

$\mathrm{ZOO}$

6
6


E. articulata (Schrank) Nees

E. maypurensis (H.B.K.) Steud.

Gymnopogon foliosus (Willd.) Nees

Ichnanthus sericeus Hack.

Imperata brasiliensis Trin.

Loudetiopsis chrysothrix (Nees) Conert

Melinis minutiflora P. Beauv.

Olyra micrantha H.B.K.

Panicum cayennensis Lam.

$P$. maximum Jacq.

P. olyroides H.B.K.

$P$. parvifolium Lam.

$P$. procurrens Nees

$P$. repens $\mathrm{L}$.

Penniseum setosum (Sw.) L.

Rhynchelitrum repens (Nees) C.E. Hubb.

Schyzachirium condensatum (Kunth) Nees

Setaria geniculata (L.) P. Beauv.

Sporolobus indicus (L.) R. Br.

Tristachya leiostachya Nees

Smilacaceae

Smilax cissoides Mart. ex Griseb

Xyridaceae

Xyris jupicai L.C. Rich

\begin{tabular}{|c|c|c|c|c|c|c|c|}
\hline TER & $\mathrm{ZOO}$ & 2 & & & $1-4$ & 4 & 1579 \\
\hline TER & $\mathrm{ZOO}$ & 23 & 3 & & 4 & 4 & 1379 \\
\hline HEM & ANE & 23 & 3 & & $4-6$ & $5-9$ & 1325 \\
\hline HEM & $\mathrm{ZOO}$ & 123 & 3 & & $9-5$ & $1-12$ & 846 \\
\hline HEM & ANE & & 4 & & $12-2$ & $12-2$ & 1622 \\
\hline HEM & $\mathrm{ZOO}$ & 123 & 3 & & $2-3$ & 4-11 & 1067 \\
\hline HEM & ANE & 123 & 34 & & $6-7$ & $6-11$ & 622 \\
\hline HEM & $\mathrm{ZOO}$ & & & 6 & 3 & $3-5$ & 1241 \\
\hline TER & $\mathrm{ZOO}$ & 23 & 34 & & - & $3-6$ & 1331 \\
\hline HEM & $\mathrm{ZOO}$ & 12 & & & $4-5$ & $5-7$ & 1266 \\
\hline HEM & $\mathrm{ZOO}$ & 23 & 34 & & $11-3$ & 3-11 & 832 \\
\hline HEM & $\mathrm{ZOO}$ & 23 & 34 & & $12-3$ & $3-10$ & 1244 \\
\hline HEM & $\mathrm{ZOO}$ & 2 & & & 3 & - & 1722 \\
\hline HEM & $\mathrm{ZOO}$ & 2 & & & $12-1$ & 6 & 1477 \\
\hline HEM & $\mathrm{ZOO}$ & & 4 & & 3 & 3 & 1643 \\
\hline TER & ANE & 23 & 34 & & $5-2$ & $5-2$ & 844 \\
\hline HEM & ANE & 23 & 34 & & 3 & $3-10$ & 1442 \\
\hline TER & $\mathrm{ZOO}$ & 2 & & & - & 5 & 1350 \\
\hline HEM & $\mathrm{ZOO}$ & & 34 & & $12-5$ & 5 & 1246 \\
\hline HEM & $\mathrm{ZOO}$ & 23 & 3 & & $2-3$ & $5-7$ & 1098 \\
\hline LIA & $\mathrm{ZOO}$ & 123 & 3 & 6 & $9-12$ & $11-2$ & 1499 \\
\hline TER & AUT & & 4 & & $9-10$ & $9-10$ & 814 \\
\hline HEM & $\mathrm{ZOO}$ & & 4 & & $9-5$ & $2-5$ & 1594 \\
\hline
\end{tabular}

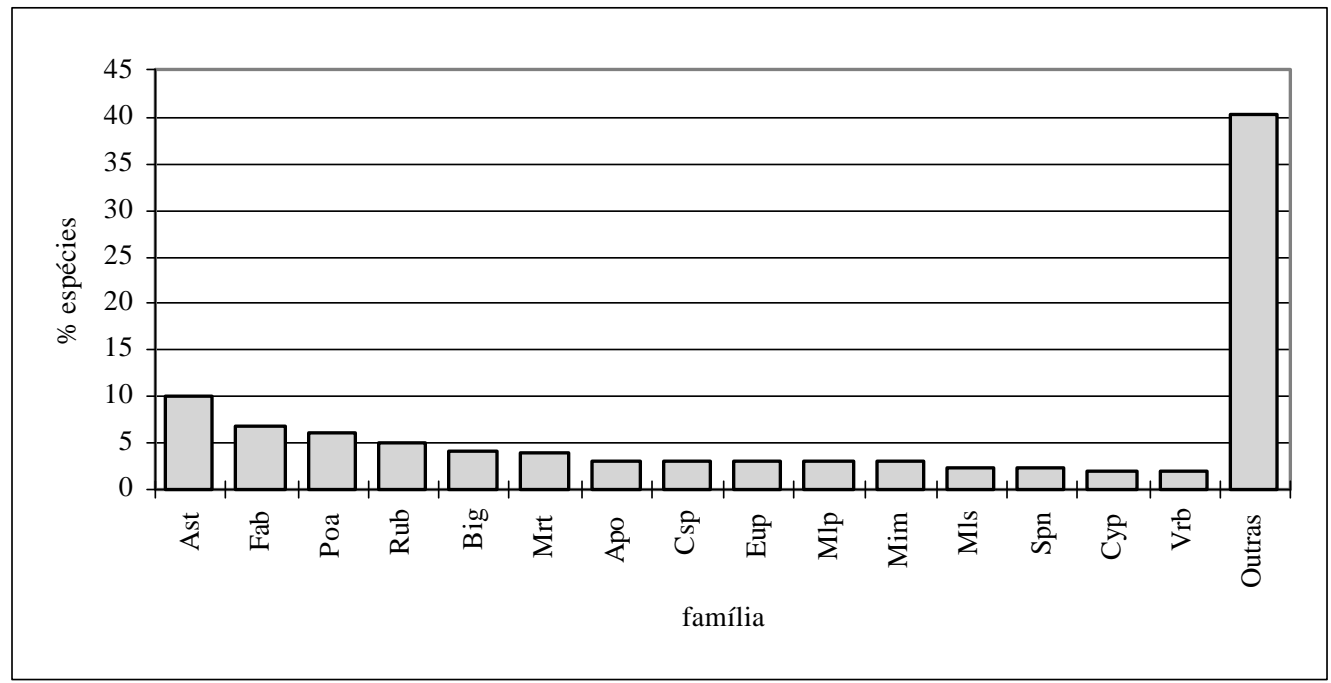

Figura 2.1 - Porcentagem de espécies nas famílias mais ricas da ARIE Cerrado Pé-de-Gigante, Santa Rita do Passa Quatro, São Paulo $\left(21^{\circ} 36-44^{\prime}\right.$ S e 4734-41'W). Ast $=$ Asteraceae, Fab $=$ Fabaceae, Poa $=$ Poaceae, Rub $=$ Rubiaceae, $\mathrm{Big}=$ Bignoniaceae, $\mathrm{Mrt}=$ Myrtaceae, $\mathrm{Apo}=$ Apocynaceae, $\mathrm{Csp}=$ Caesalpiniaceae, Eup $=$ Euphorbiaceae, Mlp $=$ Malpighiaceae, Mim $=$ Mimosaceae, Mls $=$ Melastomataceae, Spn $=$ Sapindaceae, Cyp $=$ Cyperaceae e Vrb $=$ Verbenaceae. 
Tabela 2.2 - Números de famílias, gêneros e espécies nas fisionomias da ARIE Cerrado Pé-de-Gigante, Santa Rita do Passa Quatro, SP (2136-44’S e 47³4-41’W). Legenda: fam = número de famílias; gen = número de gêneros; spp = número de espécies.

\begin{tabular}{lccccc}
\hline \multicolumn{1}{c}{ fisionomia } & fam & gen & spp & herbáceo-subarbustivas & arbustivo-arbóreas \\
\hline \hline cerradão & 51 & 113 & 147 & 70 & 83 \\
cerrado "sensu stricto" & 71 & 208 & 309 & 203 & 113 \\
campo cerrado & 68 & 187 & 272 & 197 & 82 \\
cerrado "sensu lato" & 78 & 234 & 360 & 245 & 122 \\
campo úmido & 54 & 112 & 150 & 137 & 14 \\
mata ciliar & 20 & 26 & 27 & 13 & 73 \\
floresta estacional semidecídua & 46 & 93 & 109 & 36 & 73 \\
\hline
\end{tabular}

Tabela 2.3 - Valores obtidos a partir do índice de Sørensen entre as floras das formações e fisionomias de cerrado da ARIE Cerrado Pé-de-Gigante, Santa Rita do Passa Quatro, SP (21³6-44'S e 47³4-41'W). Legenda: 1 = cerradão; 2 = cerrado "sensu stricto"; 3 = campo cerrado; 4 = campo úmido; $5=$ mata ciliar; $6=$ floresta estacional semidecídua.

\begin{tabular}{cccccc}
\hline fisionomia & 1 & 2 & 3 & 4 & 5 \\
\hline \hline 2 & 0,592 & & & & \\
3 & 0,520 & 0,802 & & & \\
4 & 0,121 & 0,318 & 0,412 & & \\
5 & 0,046 & 0,042 & 0,033 & 0,124 & 0,103 \\
6 & 0,266 & 0,158 & 0,110 & 0,039 & \\
\hline
\end{tabular}

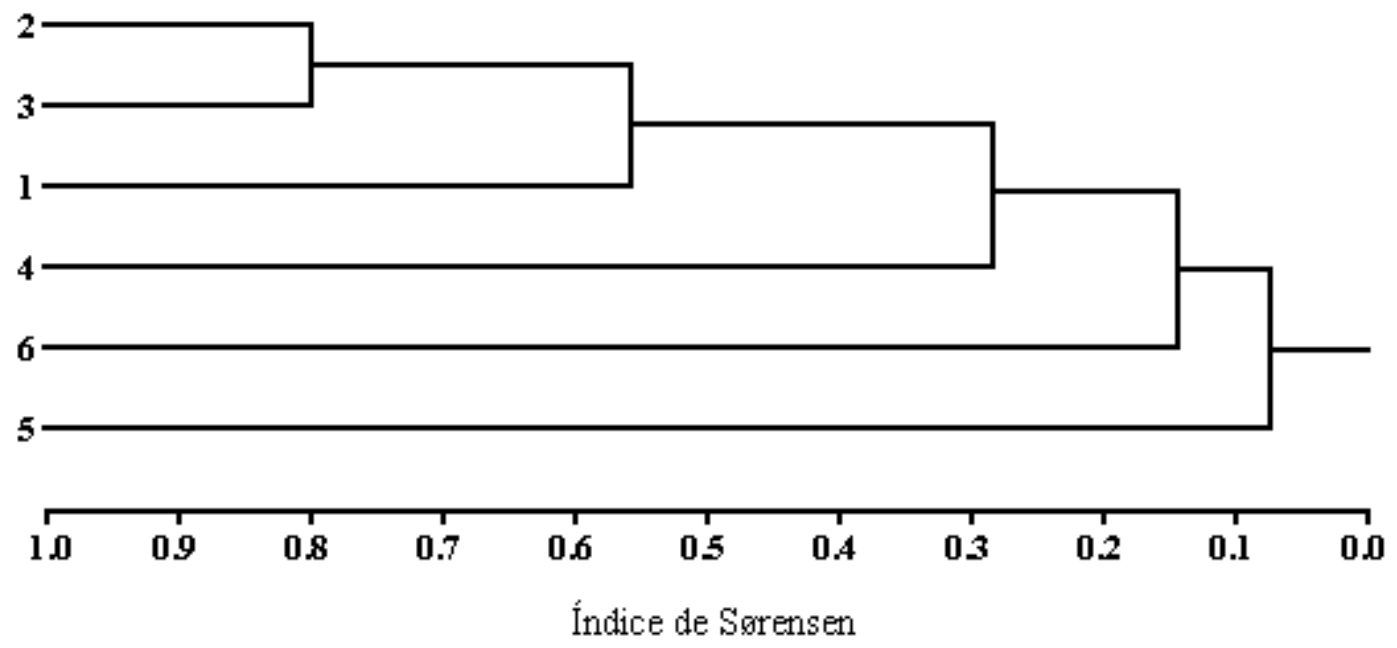

Figura 2.2 - Dendrograma dos valores obtidos a partir do índice de Sørensen entre as floras das formações e fisionomias de cerrado na ARIE Cerrado Pé-de-Gigante, Santa Rita do Passa Quatro, SP (47³4-41 'W e 21³6-44'S). Legenda: 1 = cerradão, 2 = cerrado "sensu stricto", 3 = campo cerrado, $4=$ campo úmido, 5 = mata ciliar e $6=$ floresta estacional semidecídua. 


\section{Cerrado "sensu lato"}

Nas fisionomias de cerrado (cerradão, cerrado "sensu stricto" e campo cerrado), foram amostradas 360 espécies, pertencentes a 234 gêneros e 78 famílias.

As famílias mais representadas nas fisionomias de cerrado foram, pela ordem: Asteraceae, Poaceae, Fabaceae, Rubiaceae, Myrtaceae, Bignoniaceae, Malpighiaceae, Caesalpiniaceae, Mimosaceae, Euphorbiaceae e Apocynaceae (Figura 2.3), que compreenderam 55,00\% das espécies amostradas. Estas famílias também são as mais representativas em outras áreas de cerrado estudadas, como Lagoa Santa (Warming 1892), Triângulo Mineiro (Goodland 1969), Brasília (Ratter 1980), Mogi-Guaçu (Mantovani \& Martins 1993) e Pirassununga (Batalha et al. no prelo). Fabales (Caesalpiniaceae, Fabaceae e Mimosaceae), reconhecida por sua relação com bactérias fixadoras de nitrogênio e por sua importância em ecossistemas sobre solos pobres (Cronquist 1988), representam 17,78\% do total de espécies, ou seja, mais do que a família mais rica, Asteraceae com 11,67\% do total.

Das espécies amostradas, 66 (18,33\%) são consideradas consideradas ruderais (Leitão Filho et al. 1972, Lorenzi 1991, Kissman \& Groth 1992). Destas 66, apenas 4 pertencem ao componente arbustivo-arbóreo. De acordo com Rizzini (1979), as plantas ruderais se caracterizam pela produção elevada de sementes pequenas e leves, ampla dispersão pelo vento e animais, heliofilia e ciclo de vida curto, muitas vezes anual. Estas características são encontradas com maior freqüência em espécies herbáceas.

No levantamento aqui apresentado, foram encontradas 147 espécies no cerradão, 309 no cerrado "sensu stricto" e 272 no campo cerrado. De acordo com o conceito de floresta-ecótono-campo (Coutinho 1978), seria esperado que as fisionomias ecotonais do cerrado fossem mais ricas, pois devem possuir elementos tanto da flora campestre como da florestal. De fato, as fisionomias 
ecotonais presentes na ARIE Pé-de-Gigante, cerrado "sensu stricto" e campo cerrado, foram mais ricas do que um dos extremos do conceito de Coutinho (1978), o cerradão.

Das 88 espécies identificadas por Castro (1987) em sua análise fitossociológica da reserva, duas não foram encontradas neste levantamento: Psidium warmingianum O. Berg (Myrtaceae) e Agonandra brasiliensis Miers. (Opiliaceae). Ambas as espécies apresentaram baixas freqüências e valores de importância em sua análise, podendo ser consideradas raras. Além disso, deve-se ressaltar que a porção da reserva em que este autor trabalhou foi derrubada e substituída por cultura de canade-açúcar.

A proporção entre espécies arbustivo-arbóreas e herbáceo-subarbustivas foi de 1:2, aproximadamente. Em Brasília (Ratter 1980), esta proporção também foi de 1:2, enquanto que em Lagoa Santa (Warming 1892) e Mogi-Guaçu (Mantovani \& Martins 1993) ela foi de 1:3. Tanto em Santa Rita do Passa Quatro quanto em Brasília, há predomínio de fisionomias mais fechadas de cerrado (cerradão e cerrado "sensu stricto"). Em Lagoa Santa e Mogi-Guaçu, ao contrário, predominam fisionomias mais abertas (campo cerrado e campo sujo), o que explica a maior proporção de espécies herbáceo-subarbustivas nestas duas áreas.

Em comparação com as amostragem realizadas na Fazenda Campininha, Mogi-Guaçu (Mantovani \& Martins 1993) e em Emas, Pirassununga (Batalha et al., no prelo), observa-se uma variação de 78 famílias, 234 gêneros e 360 espécies no Pé-de-Gigante, 78 famílias, 227 gêneros e 358 espécies em Emas e 85 famílias, 288 gêneros e 521 espécies na Fazenda Campininha. Embora possua uma área muito maior (1269ha), a ARIE Pé-de-Gigante apresentou riqueza florística próxima daquela encontrada em Emas (16ha) e bem menor do que a da Fazenda Campininha (342,43ha). Isto pode ser explicado pelas perturbações a que a ARIE foi submetida recentemente, como corte raso e pecuária, além da invasão de plantas ruderais no campo cerrado (Shida, em andamento), e pelo predomínio de fisionomias ecotonais mais abertas em Emas e na Fazenda Campininha. 
Os índices de similaridade (S) entre as floras obtidas na ARIE Pé-de-Gigante e na Fazenda Campininha e entre as encontradas na ARIE Pé-de-Gigante e em Emas foram, respectivamente, 0,559 e 0,666. Entre a Fazenda Campininha e Emas, este valor ficou em 0,632. A Fazenda Campininha se distingüe da ARIE Pé-de-Gigante e de Emas por sua riqueza florística, bem maior que as das duas outras áreas. Além da riqueza, a composição florística também contribuiu para separá-la das demais, ressaltando a heterogeneidade entre os diversos fragmentos de cerrado, ainda que próximos geograficamente (Tabela 2.3 e Figura 2.4). Esta heterogeneidade reflete uma alta diversidade em nível regional, ou a diversidade $\gamma$ (Whittaker 1977).

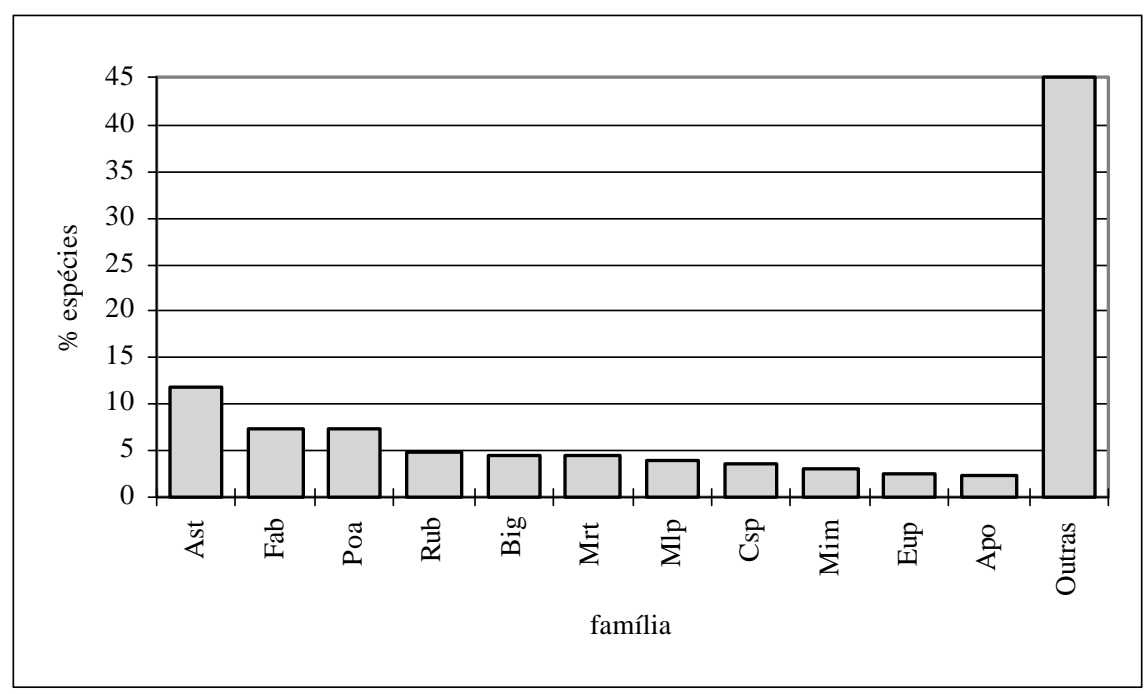

Figura 2.3 - Porcentagem de espécies nas famílias mais ricas nas fisionomias de cerrado da ARIE Cerrado Pé-de-Gigante,

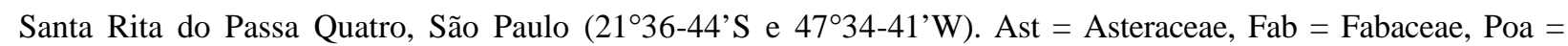
Poaceae, Rub = Rubiaceae, Big = Bignoniaceae, Mrt = Myrtaceae, Mlp = Malpighiaceae, Csp = Caesalpiniaceae, Mim = Mimosaceae, Eup = Euphorbiaceae e Apo = Apocynaceae.

Tabela 2.3 - Valores obtidos a partir do índice de Sørensen entre floras de cerrado. Legenda: pé = ARIE Cerrado Pé-deGigante, Santa Rita do Passa Quatro, São Paulo (21³6-44'S e 47³4-41'W); emas = cerrado de Emas,

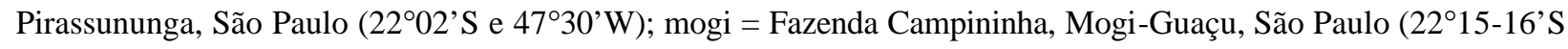
e $\left.47^{\circ} 08-12^{\prime} \mathrm{W}\right)$ 


\begin{tabular}{ccc}
\hline área & pé & emas \\
\hline \hline emas & 0,666 & \\
mogi & 0,559 & 0,632 \\
\hline
\end{tabular}

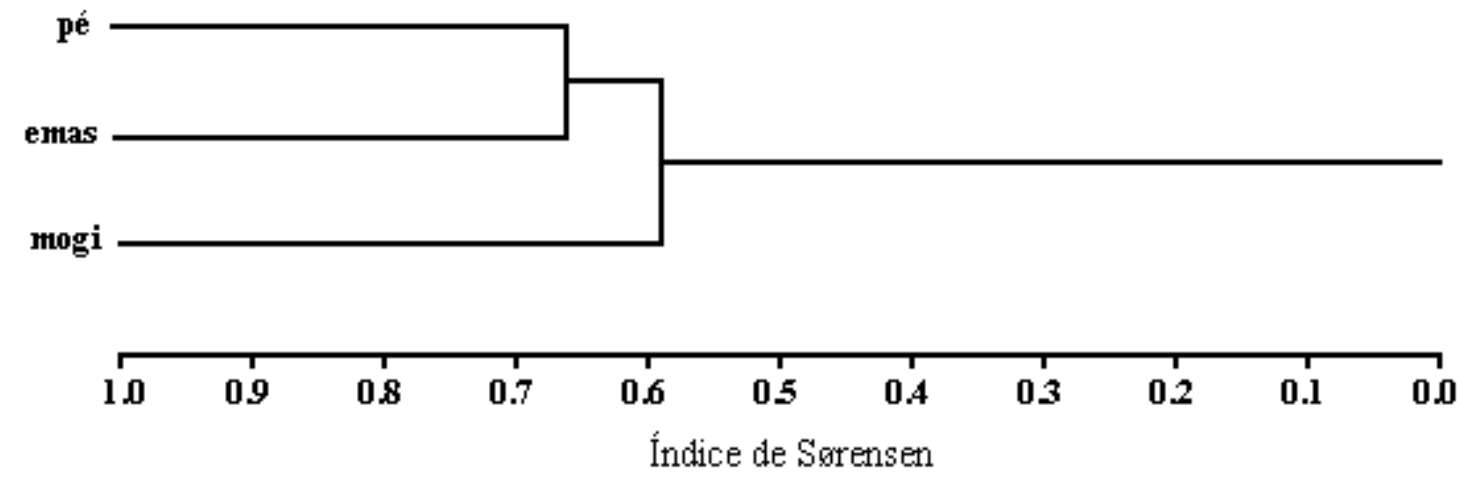

Figura 2.4 - Dendrograma dos valores obtidos a partir do índice de Sørensen entre floras de cerrado. Legenda: pé = ARIE Cerrado Pé-de-Gigante, Santa Rita do Passa Quatro, São Paulo (21³6-44’S e 47³4-41’W); emas = cerrado de

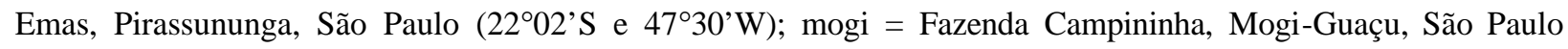
$\left(22^{\circ} 15-16^{\prime} \mathrm{S}\right.$ e $\left.47^{\circ} 08-12^{\prime} \mathrm{W}\right)$.

\section{- componente herbáceo-subarbustivo}

As 245 espécies herbáceo-subarbustivas perfizeram 68,05\% da flora como um todo. As famílias apenas com espécies deste componente representaram 43,60\% das famílias da flora como um todo, valor próximo daqueles obtidos em Mogi-Guaçu (41,46\%) (Mantovani \& Martins 1993) e em Pirassununga $(46,15 \%)$ (Batalha et al. no prelo).

As famílias mais ricas neste componente foram, pela ordem: Asteraceae, Poaceae, Fabaceae, Rubiaceae, Bignoniaceae, Malpighiaceae, Euphorbiaceae, Malvaceae, Lamiaceae, Verbenaceae, Sapindaceae, Cyperaceae e Caesalpiniaceae (Figura 2.5), que compreenderam 66,94\% das espécies herbáceo-subarbustivas. Estas famílias também são as mais representativas neste componente em outras áreas de cerrado, como em Mogi-Guaçu e em Pirassununga.

Os índices de similaridade (S) entre a flora da ARIE Pé-de-Gigante e a da Fazenda Campininha e 
entre a do Pé-de-Gigante e a de Emas foram, respectivamente, 0,481 e 0,623. Entre a Fazenda Campininha e Emas, este valor foi de 0,586 (Tabela 2.4 e Figura 2.6). A grande riqueza de espécies herbáceo-subarbustivas encontradas na Fazenda Campininha (403) contribuiu para distingüi-la da ARIE Pé-de-Gigante e de Emas (245 e 255 espécies, respectivamente). Os valores do índice de similaridade para este componente são menores do que aqueles encontrados para o componente arbustivo-arbóreo, mostrando que a heterogeneidade da flora campestre é maior do que a da arbórea. Esta variação se dá, principalmente, no nível de espécies, já que no de famílias e de gêneros se mantém, aproximadamente, constantes.

Poucos são os trabalhos que analisam as espécies herbáceo-subarbustivas. A sazonalidade da porção epígea das espécies campestres, que pode variar de poucos meses a dois anos, contribui para o escasso conhecimento deste componente. Em função do ciclo epígeo curto de muitas espécies e dependendo da freqüência e da intensidade das queimadas, a composição do componente herbáceosubarbustivo altera-se bastante ao longo do ano (Mantovani 1990).

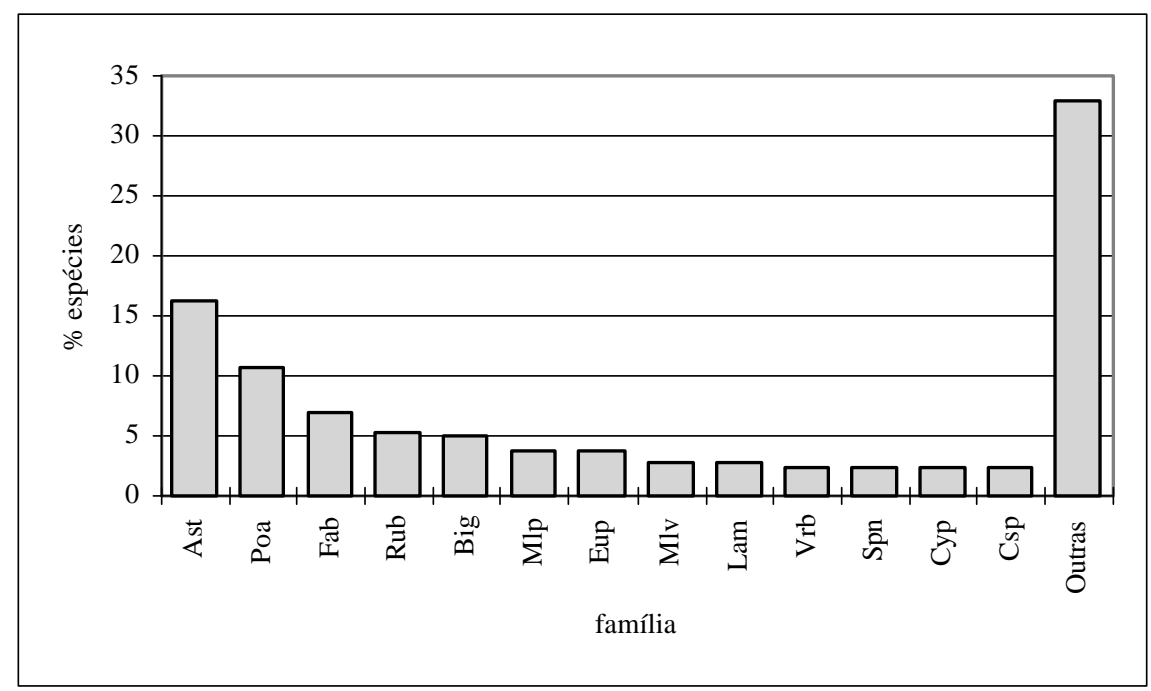

Figura 2.5 - Porcentagem de espécies nas famílias mais ricas no componente herbáceo-subarbustivo das fisionomias de cerrado da ARIE Cerrado Pé-de-Gigante, Santa Rita do Passa Quatro, São Paulo (21³6-44'S e 47³4-41'W). Ast = Asteraceae, Poa $=$ Poaceae, Fab $=$ Fabaceae, Rub $=$ Rubiaceae, Big $=$ Bignoniaceae, Mlp $=$ Malpighiaceae, Eup $=$ 
Euphorbiaceae, Mlv $=$ Malvaceae, Lam $=$ Lamiaceae, $\mathrm{Vrb}=$ Verbenaceae, Spn $=$ Sapindaceae, Cyp $=$ Cyperaceae e Csp $=$ Caesalpiniaceae. 
Tabela 2.4 - Valores obtidos a partir do índice de Sørensen entre floras herbáceo-subarbustivas de cerrado. Legenda: pé = ARIE Cerrado Pé-de-Gigante, Santa Rita do Passa Quatro, São Paulo (21³6-44'S e 47³4-41'W); emas = cerrado de Emas, Pirassununga, São Paulo (2202’S e 47³0’W); mogi = Fazenda Campininha, Mogi-Guaçu, São Paulo $\left(22^{\circ} 15-16^{\prime} \mathrm{S}\right.$ e $\left.47^{\circ} 08-12^{\prime} \mathrm{W}\right)$.

\begin{tabular}{ccc}
\hline área & pé & emas \\
\hline \hline emas & 0,623 & \\
mogi & 0,481 & 0,586 \\
\hline
\end{tabular}

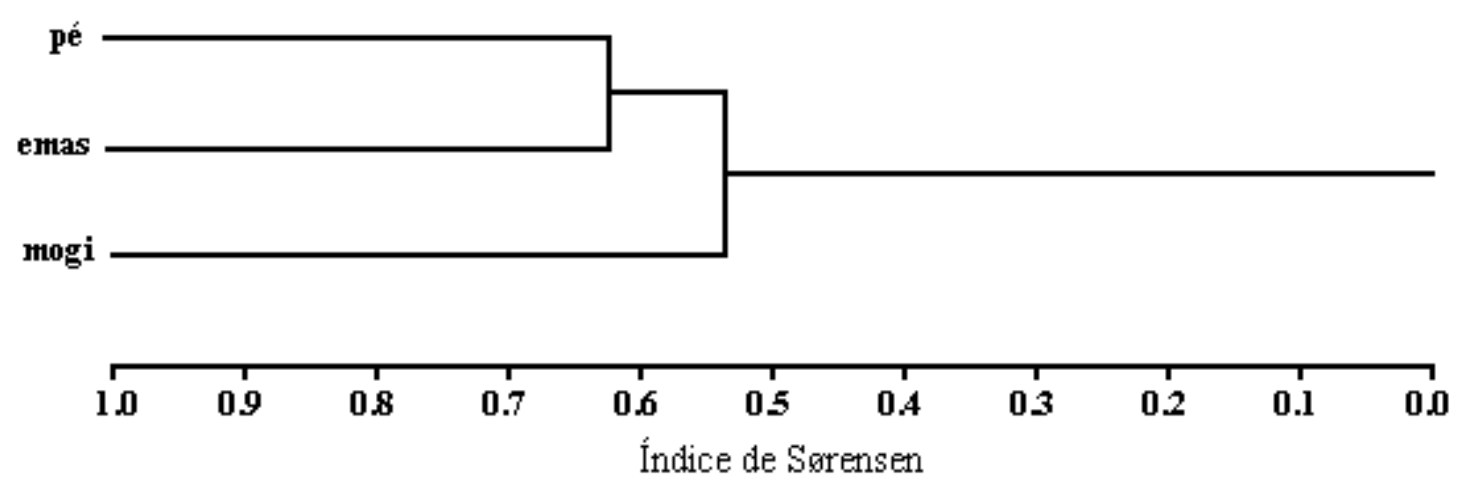

Figura 2.6 - Dendrograma dos valores obtidos a partir do índice de Sørensen entre floras herbáceo-subarbustivas de cerrado. Legenda: pé = ARIE Cerrado Pé-de-Gigante, Santa Rita do Passa Quatro, São Paulo (21³6-44’S e 47³4-

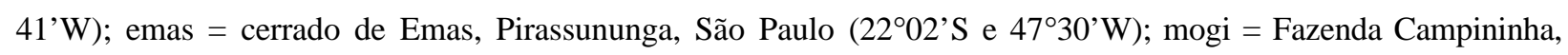
Mogi-Guaçu, São Paulo (22¹5-16’S e 4708-12’W).

\section{- componente arbustivo-arbóreo}

As 122 espécies arbustivo-arbóreas representaram 33,89\% da flora como um todo. Das famílias amostradas na flora como um todo, 26,92\% tiveram exclusivamente espécies do componente arbustivo-arbóreo, valor que se situa entre aquele encontrado em Mogi-Guaçu (35,36\%) (Mantovani \& Martins 1993) e em Pirassununga (23,08\%) (Batalha et al., no prelo).

Neste componente, as famílias com maiores riquezas foram: Myrtaceae, Fabaceae, Caesalpiniaceae, Mimosaceae, Melastomaceae, Vochysiaceae, Bignoniaceae, Malpighiaceae, Rubiaceae, Annonaceae e Erythroxylaceae (Figura 2.7), que englobaram 59,02\% das espécies 
amostradas. Da mesma forma, estas famílias estão entre as mais representativas em Mogi-Guaçu e Pirassununga.

Foram amostradas 122 espécies arbustivo-arbóreas na ARIE Pé-de-Gigante, 109 em Emas e 125 na Fazenda Campininha. Entre as floras do Pé-de-Gigante e da Fazenda Campininha e entre as do Pé-de-Gigante e de Emas, os índices de similaridade (S) foram, pela ordem, 0,785 e 0,774. Já entre a Fazenda Campininha e Emas, o valor foi de 0,781 (Tabela 2.5 e Figura 2.8). Em função das riquezas semelhantes, estes valores são maiores do que aqueles encontrados para o componente herbáceosubarbustivo.

Castro (1994) realizou uma extensa compilação de diversos trabalhos florísticos e fitossociológicos feitos em cerrado e elaborou uma listagem das espécies arbustivo-arbóreas. Das espécies aqui amostradas, apenas Myrcia guianensis (Aubl.) A. DC. (Myrtaceae) e Syagrus romanzoffiana (Cham.) Glass. (Arecaceae) não foram relacionadas pelo autor.

Andira anthelmia (Vell.) J. Macbr. (Fabaceae), Byrsonima crassa Naud. (Malpighiaceae), Anadenanthera peregrina (L.) Speg. (Mimosaceae), Eugenia langsdorfii O. Berg (Myrtaceae) e Luehea divaricata Mart. (Tiliaceae) não foram indicadas como ocorrentes nos cerrados do estado de São Paulo por Leitão-Filho (1992) e devem ser acrescentadas a esta lista.

Por outro lado, Myrcia pubipetala Miq. (Myrtaceae), asssim como Myrcia guianensis e Syagrus romanzoffiana, embora tenham sido amostradas em fisionomias de cerrado, não são características deste tipo de vegetação e devem ser mantidas fora das duas listagens. 


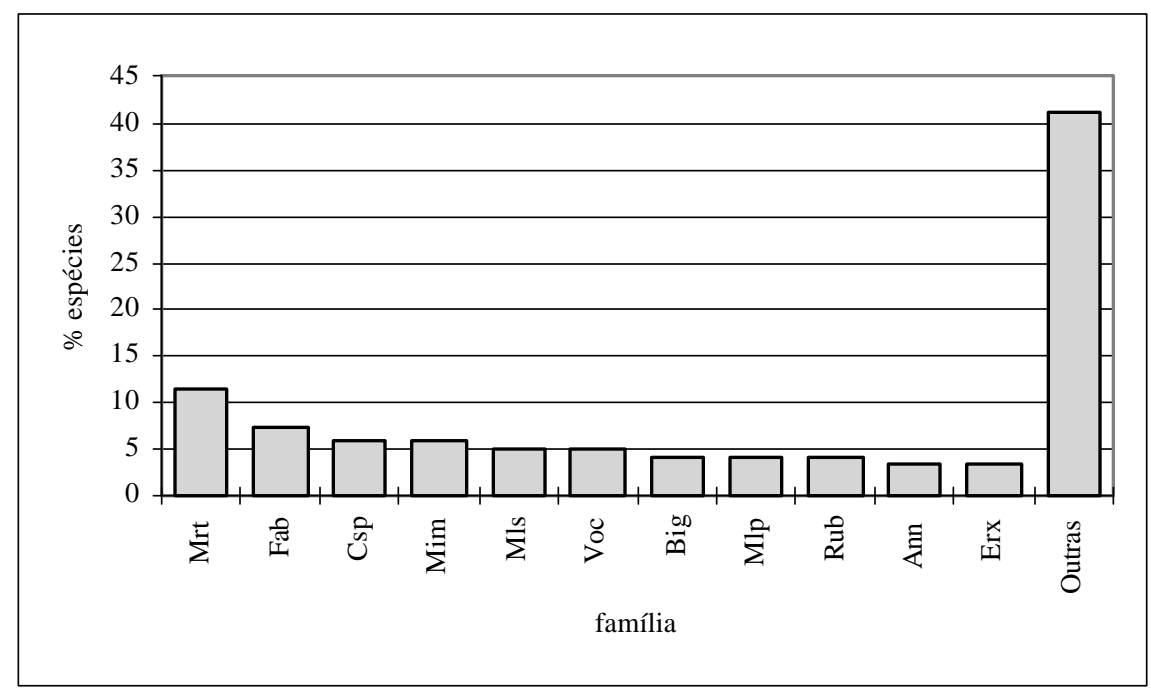

Figura 2.7 - Porcentagem de espécies nas famílias mais ricas no componente arbustivo-arbóreo das fisionomias de cerrado da ARIE Cerrado Pé-de-Gigante, Santa Rita do Passa Quatro, São Paulo (21³6-44'S e 47³4-41'W). Mrt = Myrtaceae, Fab = Fabaceae, $\mathrm{Csp}=$ Caesalpiniaceae, Mim = Mimosaceae, Mls = Melastomataceae, Voc $=$ Vochysiaceae, Big = Bignoniaceae, Mlp = Malpighiaceae, Rub = Rubiaceae, Ann = Annonaceae e Erx $=$ Erythroxylaceae.

Tabela 2.5 - Valores obtidos a partir do índice de Sørensen entre floras arbustivo-arbóreas de cerrado. Legenda: pé = ARIE Cerrado Pé-de-Gigante, Santa Rita do Passa Quatro, São Paulo (21³6-44'S e 47³4-41'W); emas = cerrado de Emas, Pirassununga, São Paulo (2202’S e 47³0’W); mogi = Fazenda Campininha, Mogi-Guaçu, São Paulo (22 ${ }^{\circ} 15-16^{\prime} \mathrm{S}$ e $\left.47^{\circ} 08-12^{\prime} \mathrm{W}\right)$.

\begin{tabular}{ccc}
\hline área & pé & emas \\
\hline \hline emas & 0,774 & \\
mogi & 0,785 & 0,781 \\
\hline
\end{tabular}

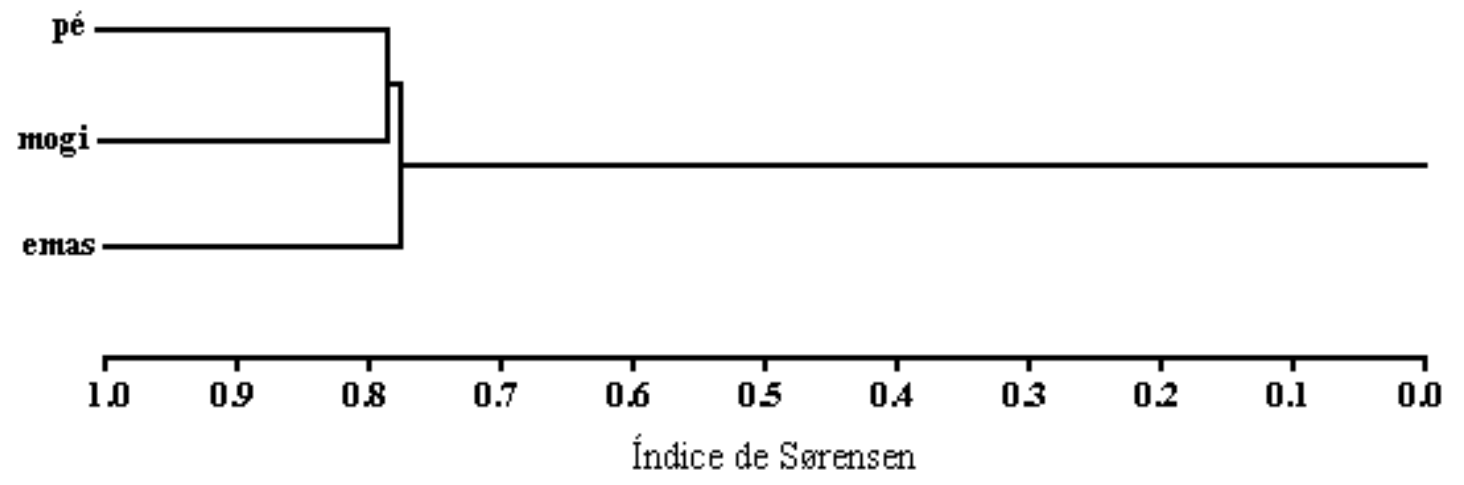

Figura 2.8 - Dendrograma dos valores obtidos a partir do índice de Sørensen entre floras arbustivo-arbóreas de cerrado. Legenda: pé = ARIE Cerrado Pé-de-Gigante, Santa Rita do Passa Quatro, São Paulo (21³6-44’S e 47³4-41’W); emas = cerrado de Emas, Pirassununga, São Paulo (2202'S e 47³0’W); mogi = Fazenda Campininha, Mogi-Guaçu, São Paulo $\left(22^{\circ} 15-16^{\prime}\right.$ S e $\left.47^{\circ} 08-12^{\prime} \mathrm{W}\right)$. 


\section{Campo úmido}

Foram encontradas nesta formação 150 espécies, pertencentes a 112 gêneros e 54 famílias (Tabela 2.2). Do total de espécies amostradas, 91,33\% são herbáceo-subarbustivas.

As famílias mais representadas foram: Asteraceae, Poaceae, Cyperaceae, Fabaceae, Caesalpiniaceae, Euphorbiaceae, Melastomataceae, Malpighiaceae e Solanaceae (Figura 2.9), que compreenderam 58,00\% das espécies amostradas.

Das espécies amostradas nesta formação, 66 (44\%) são consideradas ruderais (Leitão Filho et al. 1972, Lorenzi 1991, Kissman \& Groth 1992). Esta alta porcentagem de plantas invasoras é conseqüência de atividades antrópicas que foram praticadas na reserva. Esta área de campo úmido foi utilizada para pastagem de bovinos há pouco tempo (Shida, em andamento) e é, dentro da ARIE Pé-de-Gigante, o principal foco para entrada de plantas ruderais. Uma das espécies encontradas,

Citrus aurantiifolia (Rutaceae), é cultivada, mostrando que a área foi utilizada também para o plantio de árvores frutíferas.

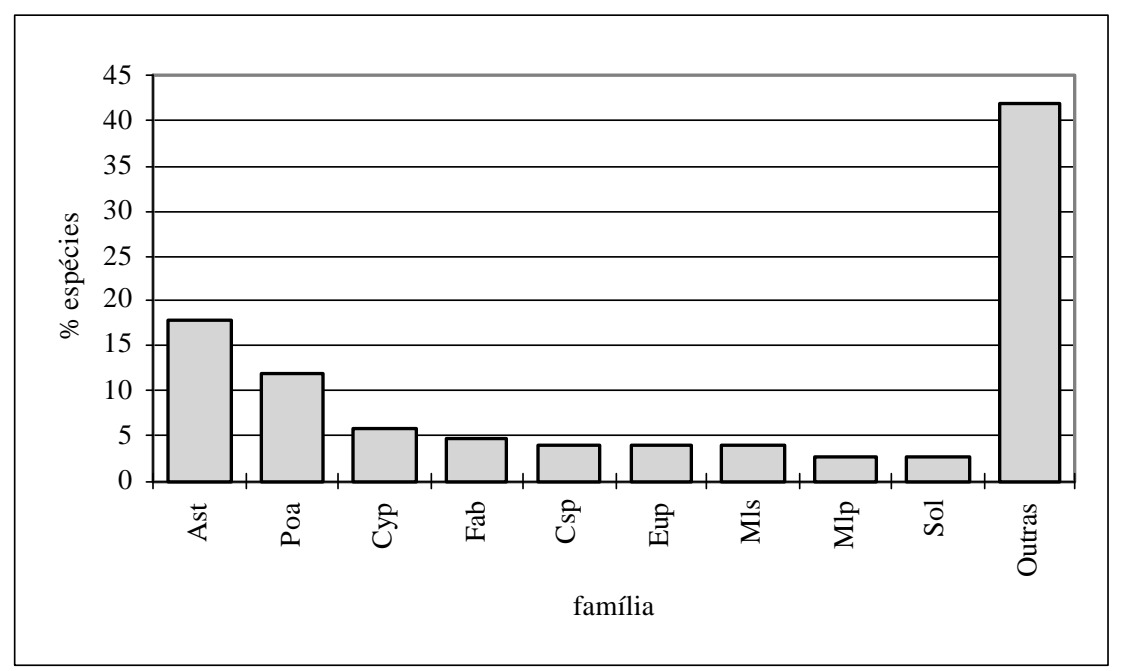

Figura 2.9 - Porcentagem de espécies nas famílias mais ricas no campo úmido da ARIE Cerrado Pé-de-Gigante, Santa Rita do Passa Quatro, São Paulo (2136-44’S e 47³4-41’W). Ast = Asteraceae, Poa = Poaceae, Cyp = Cyperaceae, Fab $=$ Fabaceae, Csp = Caesalpiniaceae, Eup = Euphorbiaceae, Mls = Melastomataceae, Mlp = Malpighiaceae e Sol = Solanaceae. 


\section{Mata ciliar}

Amostraram-se 27 espécies na mata ciliar, distribuídas em 26 gêneros e 20 famílias. Destas espécies, aproximadamente metade é de herbáceo-subarbustivas (13) e metade, de arbustivoarbóreas (14). A baixa riqueza florística desta formação pode ser explicada por sua pequena área e pelo grau de degradação em que se encontra, enfatizado pelas lianas que crescem sobre os indivíduos arbóreos, muitos dos quais já mortos. São consideradas ruderais (Leitão Filho et al. 1972, Lorenzi 1991, Kissman \& Groth 1992) 4 das 27 espécies amostradas nesta formação, ou $14,81 \%$.

Bignoniaceae, Euphorbiaceae, Mimosaceae, Monimiaceae e Rubiaceae representam 44,44\% das espécies encontradas e são as famílias com maiores riquezas florísticas (Figura 2.10). As demais famílias são representadas por apenas uma espécie cada.

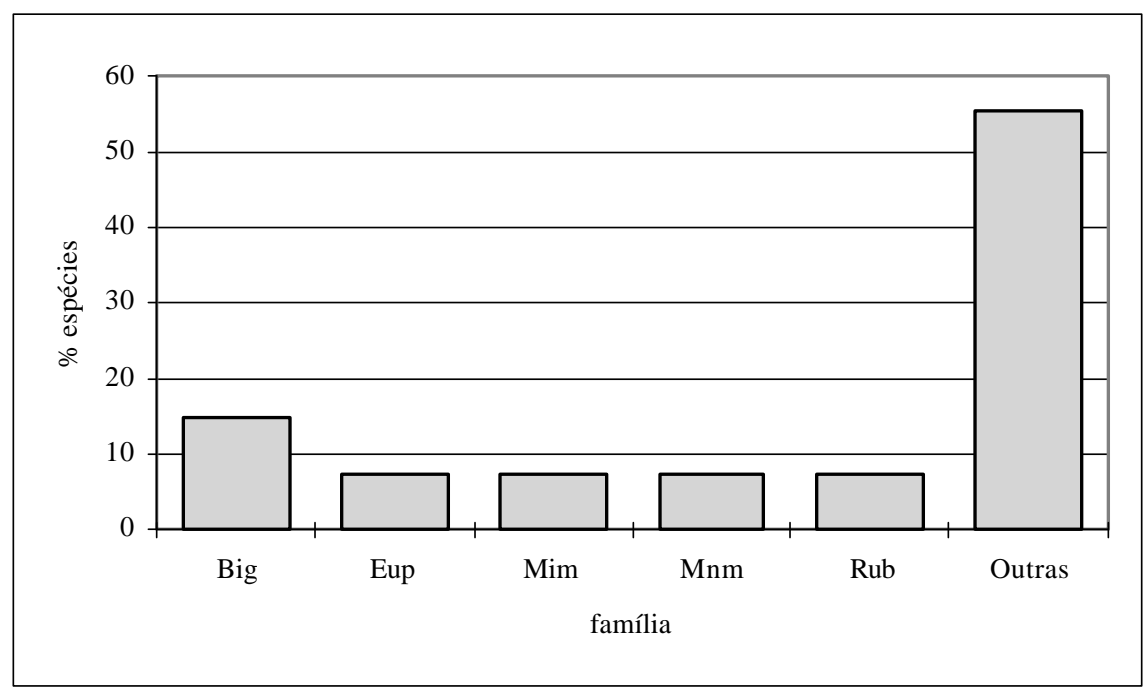

Figura 2.10 - Porcentagem de espécies nas famílias mais representativas na mata ciliar da ARIE Cerrado Pé-de-Gigante, Santa Rita do Passa Quatro, São Paulo (213- $44^{\prime}$ S e 47³4-41'W). Big = Bignoniaceae, Eup = Euphorbiaceae, Mim $=$ Mimosaceae, $\mathrm{Mnm}=$ Moniamiaceae e Rub $=$ Rubiaceae. 


\section{Floresta estacional semidecídua}

Na floresta estacional semidecídua, foram encontradas 109 espécies, de 93 gêneros e 46 famílias. Destas 109 espécies, 36 (33,03\%) são herbáceo-subarbustivas e 73 (66,97\%), arbustivo-arbóreas.

Rubiaceae, Fabaceae, Myrtaceae, Bignoniaceae, Sapindaceae, Apocynaceae, Asteraceae, Caesalpiniaceae, Euphorbiaceae, Mimosaceae e Rutaceae foram, nesta ordem, as famílias mais ricas, correspondendo a 54,63\% do total de espécies (Figura 2.11).

Das 109 espécies amostradas, 5 (4,59\%) são consideradas ruderais (Leitão Filho et al. 1972, Lorenzi 1991, Kissman \& Groth 1992). Embora atividades antrópicas tenham sido desenvolvidas na floresta estacional (Shida, em andamento), esta baixa porcentagem de espécies ruderais nesta formação, ao contrário do que foi encontrado no cerrado e, principalmente, no campo úmido, é consequiência da intolerância destas plantas à sombra (Rizzini 1979).

Martins (1991) estudou o componente arbustivo-arbóreo, pelo método de quadrantes, de outra floresta estacional semidecídua da região, no Parque Estadual de Vassununga, localizado também no município de Santa Rita do Passa Quatro.

Os índices de Sørensen (S), obtidos comparando-se a flora do componente arbustivo-arbóreo da floresta estacional semidecídua da ARIE Pé-de-Gigante com a da floresta do Parque Estadual de Vassununga e com a do cerradão do próprio Pé-de-Gigante foram de 0,242 e 0,295, respectivamente. Entre o cerradão e a floresta estacional de Vassununga, este índice correspondeu a 0,011 (Tabela 2.6 e Figura 2.12). Estes valores indicam que a floresta estacional semidecídua em regiões de ocorrência do cerrado, pode conter espécies de sua fisionomia florestal, conforme indicara Löfgren (1896), embora ressalvas devam ser feitas quanto às diferenças entre os métodos e critérios de amostragem adotados nas duas áreas. Além disto, a própria contigüidade entre as duas formações na ARIE favorece uma maior contribuição florística do cerradão à flora da floresta 
estacional.

Martins (1991) concluiu que, embora tenha havido corte seletivo de árvores em Vassununga, a comunidade se encontra em um estádio pré-climácico de sucessão. No Pé-de-Gigante, por sua vez, o impacto das atividades antrópicas - como o corte seletivo de madeira - foi mais intenso e mais recente (Shida, em andamento) e, também, deve ter contribuído para a dissimilaridade com a floresta estacional no Parque de Vassununga.

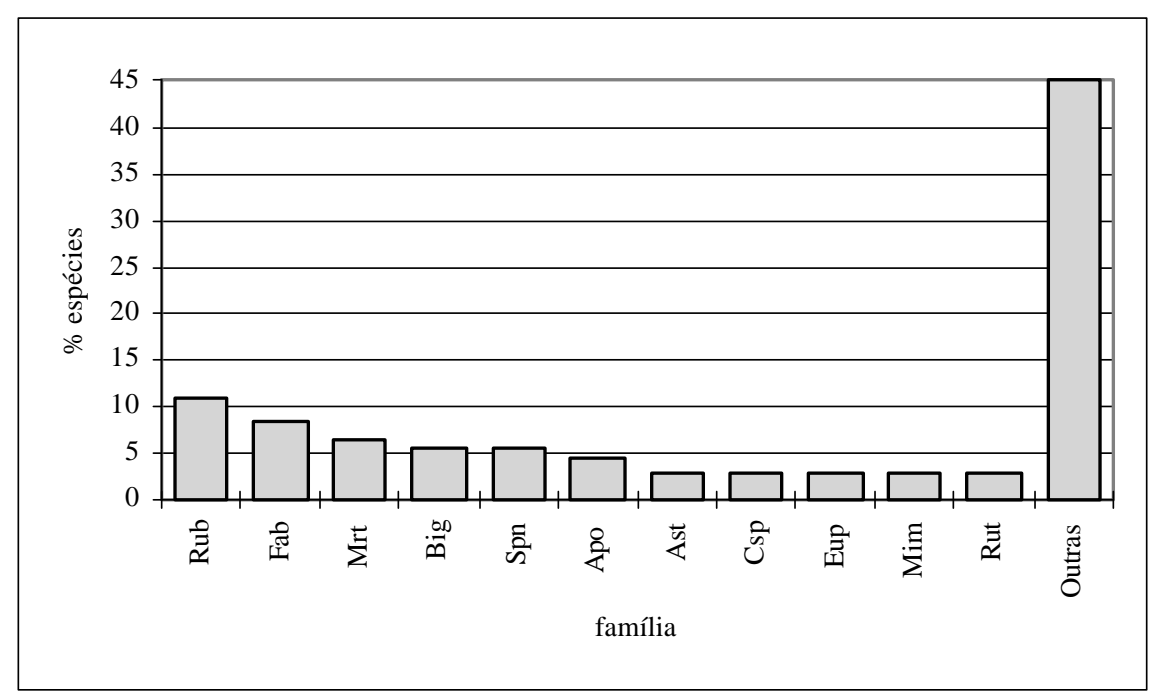

Figura 2.11 - Porcentagem de espécies nas famílias mais ricas na floresta estacional semidecídua da ARIE Cerrado Péde-Gigante, Santa Rita do Passa Quatro, São Paulo (21³6-44'S e 47³4-41'W). Rub = Rubiaceae, Fab = Fabaceae, Mrt $=$ Myrtaceae, Big $=$ Bignoniaceae, Spn $=$ Sapindaceae, Apo $=$ Apocynaceae, Ast $=$ Asteraceae, Csp $=$ Caesalpiniaceae, Eup = Euphorbiaceae, Mim = Mimosaceae e Rut $=$ Rutaceae.

Tabela 2.6 - Valores obtidos a partir do índice de Sørensen entre floras do cerradão e de duas áreas de floresta estacional semidecídua. Legenda: pé = ARIE Cerrado Pé-de-Gigante, Santa Rita do Passa Quatro, São Paulo (21ํ36-44'S e 47 34-41’W); vassununga = Parque Estadual de Vassununga, São Paulo (214ㄱ'S e 47³5’ W).

\begin{tabular}{ccc}
\hline área & cerradão (pé) & flor. estacional (pé) \\
\hline \hline flor. estacional (pé) & 0,295 & \\
flor. estacional (vassununga) & 0,011 & 0,242 \\
\hline
\end{tabular}




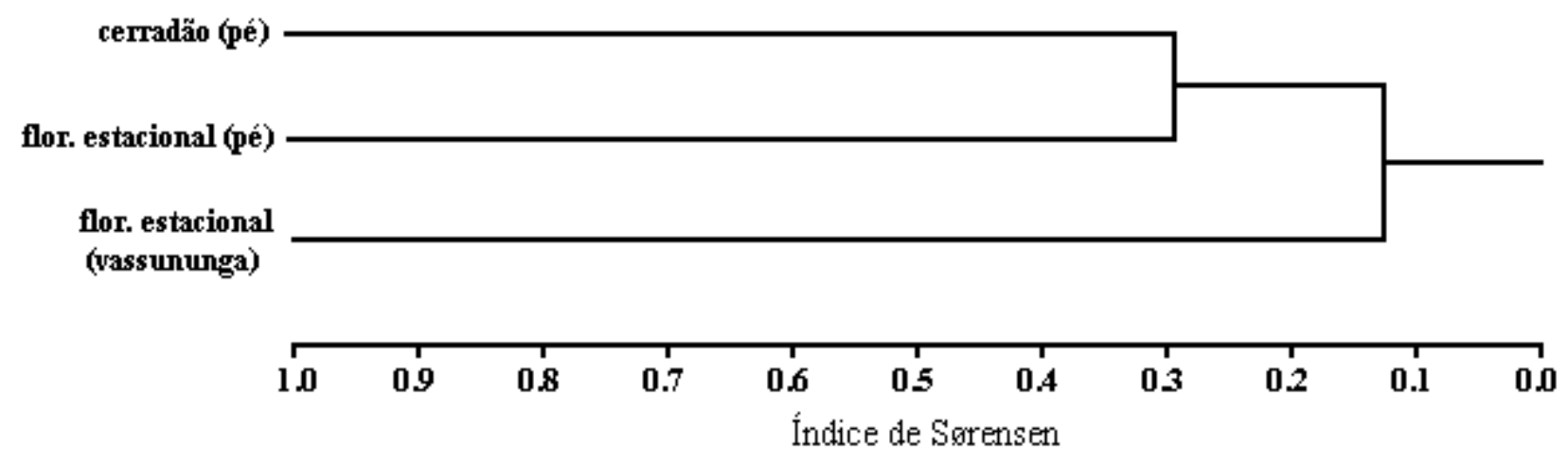

Figura 2.12 - Dendrograma dos valores obtidos a partir do índice de Sørensen entre as floras de cerradão e de duas áreas de floresta estacional semidecídua. Legenda: pé = ARIE Cerrado Pé-de-Gigante, Santa Rita do Passa Quatro, São

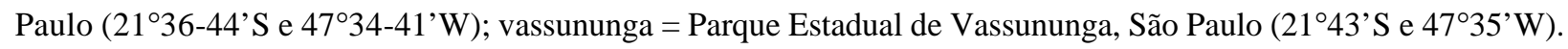

\section{Conclusões}

Os resultados aqui obtidos mostram, como apontado em outros trabalhos, que há uma unidade florística do cerrado, com suas fisionomias ecotonais contendo elementos campestres e florestais.

As famílias mais representativas no cerrado "sensu lato" foram as mesmas encontradas em outros estudos realizados nesta formação. A proporção de espécies arbustivo-arbóreas e herbáceosubarbustivas foi de 1:2, em função do predomínio de cerrado "sensu stricto" na reserva. A comparação com outros levantamentos realizados em áreas de cerrado próximas mostrou a heterogeneidade do cerrado, ressaltada pela variação florística, principalmente, do componente herbáceo-subarbustivo.

No campo úmido, por seu histórico de ocupação, a invasão de plantas ruderais foi grande e, provavelmente, responsável por uma diminuição em sua riqueza florística. A mata ciliar encontra-se bastante degradada, o que é indicado pela grande quantidade de lianas sobre os indivíduos do componente dominante e pelo grande número de indivíduos mortos.

A floresta estacional semidecídua encontrada no interior da reserva contém espécies encontradas no cerradão, sendo floristicamente distinta de outra área de floresta estacional da região, em estado 
sucessional mais adiantado. Os valores do índice de similaridade confirmam que, em regiões de ocorrência de cerrado, áreas de florestas estacionais podem conter espécies da fisionomia florestal do cerrado, ou seja, do cerradão.

\section{Referências bibliográficas}

AZEVEDO, L. G. 1967. Tipos eco-fisionômicos de vegetação do Território Federal do Amapá. Revta. Bras. Geogr. 29: 25-51.

BATALHA, M. A.; ARAGAKI, S. \& MANTOVANI, W. No prelo. Florística do cerrado em Emas (Pirassununga, SP). Bolm. Bot. Univ. S. Paulo.

BORGONOVI, M. \& CHIARINI, J. V. 1965. Cobertura vegetal do Estado de São Paulo. I Levantamento por fotointerpretação das áreas cobertas com cerrado, cerradão e campo. Bragantia 24: 159-72.

CASTRO, A. A. J. F. 1987. Florística e fitossociologia de um cerrado marginal brasileiro, Parque Estadual de Vassununga, Santa Rita do Passa-Quatro, SP. Tese de Mestrado. Univ. Est. Campinas.

CASTRO, A. A. J. F. 1994. Comparação florístico-geográfica (Brasil) e fitossociológica (Piauí São Paulo) de amostras de cerrado. Tese de Doutorado. Univ. Fed. Piauí.

CAVASSAN, O. 1990. Florística e fitossociologia da vegetação lenhosa em um hectare de cerrado no Parque Ecológico Municipal de Bauru (SP). Tese de Doutorado. Univ. Est. Campinas.

COUTINHO, L. M. 1978. O conceito do cerrado. Rev. Bras. Bot. 1: 17-23.

CRONQUIST, A. 1988. The evolution and classification of flowering plants. New York, The New York Botanical Garden. 
DUCKE, A. \& BLACK, G. A. 1954. Phytogeographical notes on the brazilian Amazon. Bolm. Téc. Inst. Agron. N. 29:1-62.

EITEN, G. 1963. Habitat flora of fazenda Campininha, São Paulo, Brazil. In: FERRI, M. G. (coord). I Simpósio sobre o cerrado, São Paulo, Edgard Blücher e EDUSP.

EITEN, G. 1970. A vegetação do estado de São Paulo. Bolm. Inst. Bot. S. Paulo 7:1-147.

FELFILI, J. M.; FILGUEIRAS, T. de S.; HARIDASSAN, M.; SILVA JÚNIOR, M. C. de; MENDONÇA, R. C. de \& REZENDE, A. V. 1994. Projeto bioeografia do bioma cerrado: vegetação \& solos. Cad. Geoc. 12: 75-166.

FERRI, M. G. 1960. Nota preliminar sobre a vegetação de cerrado em Campo de Mourão (PR). Bol. Fac. Fil. Ciênc. Univ. S. Paulo, Botânica 4:161-224.

GIANOTTI, E. 1988. Composição florística e estrutura fitossociológica da vegetação de cerrado e de transição entre cerrado e mata ciliar da Estação Experimental de Itirapina (SP). Tese de Mestrado. Univ. Est. Campinas.

GOODLAND, R. 1969. Análise ecológica da vegetação de cerrado. In: GOODLAND, R. \& FERRI, M. G. Ecologia do cerrado. Belo Horizonte, Itatiaia; São Paulo, EDUSP.

HERINGER, E. P.; BARROSO, G. M.; RIZZO, J. A. \& RIZZINI, C. T. 1976. A flora do cerrado. In: FERRI, M. G. IV Simpósio sobre o cerrado. Belo Horizonte, Itatiaia; São Paulo, EDUSP. KISSMAN, K. G. \& GROTH, D. 1992. Plantas infestantes e nocivas. São Paulo, BASF Brasileira. $3 \mathrm{v}$.

LEITÃO FILHO, H. de F, ARANHA, C. \& BACCHI, O. 1972. Plantas invasoras de culturas no estado de São Paulo. São Paulo, HUCITEC. 3v.

LEITÃO FILHO, H. de F. 1992. A flora arbórea dos cerrados do estado de São Paulo. Hoehnea 19(1/2):121-63.

LÖFGREN, A. 1896. Ensaio para uma distribuição dos vegetais nos diversos grupos florísticos no 
estado de São Paulo. Bolm. Com. Geogr. Geol. S. Paulo 11:1-50.

LORENZI, H. 1991. Plantas daninhas do Brasil: terrestres, aquáticas, parasitas, tóxicas e medicinais. Nova Odessa, Plantarum.

MAGURRAN, A. E. 1988. Ecological diversity and its measurement. Princeton, Princeton Univ. Press.

MANTOVANI, W. 1983. Composição e similaridade florística, fenologia e espectro biológico do cerrado da reserva biológica de Moji Guaçu, Estado de São Paulo. Dissertação de Mestrado. Univ. Est. Campinas.

MANTOVANI, W. 1987. Análise florística e fitossociológica do estrato herbáceo-subarbustivo do cerrado na reserva biológica de Moji Guaçu e em Itirapina, SP. Tese de Doutorado. Univ. Est. Campinas.

MANTOVANI, W. 1990. O estrato herbáceo do cerrado na região sudeste do Brasil. In: $8^{\circ}$ CONGRESSO DA SOCIEDADE BOTÂNICA DE SÃO PAULO (ed). SBSP, Campinas.

MANTOVANI, W. \& MARTINS, F. R. 1993. Florística do cerrado na reserva biológica de Moji Guaçu, SP. Acta Bot. Bras. 7: 33-60.

MARTINS, F. R. 1991. Estrutura de uma floresta mesófila. Campinas, Univ. Est. Campinas.

MEIRA NETO, J. A. A. 1991. Composição florística e estrutura fitossociológica de fisionomias de cerrado "sensu lato" da Estação Ecológica de Santa Bárbara - Município de Águas de Santa Bárbara - Estado de São Paulo. Tese de Mestrado. Univ. Est. Campinas.

MUELLER-DOMBOIS, D. \& ELLENBERG, H. 1974. Aims and methods of vegetation ecology. New York, John Willey \& Sons.

NASCIMENTO, M. T. \& SADDI, N. 1992. Structure and floristic composition in an area of cerrado in Cuiabá - MT, Brazil. Revta. Bras. Bot. 15(1): 47-55.

OLIVEIRA E SOUZA, M. H. A. 1977. Alguns aspectos ecológicos da vegetação na região 
perimetral da Represa do Lobo (Brotas - Itirapina, SP). Tese de Doutorado. Univ. S. Paulo.

OLIVEIRA FILHO, A. T. 1984. Estudo florístico e fitossociológico em um cerrado na Chapada dos Guimarães - Mato Grosso - uma análise de gradientes. Tese de Mestrado. Univ. Est. Campinas.

PAGANO, S. M.; CESAR, O \& LEITÃO FILHO, H. de F. 1989a. Composição florística do estrato arbustivo-arbóreo da vegetação de cerrado da Área de Proteção Ambiental (APA) de Corumbataí - Estado de São Paulo. Revta. Brasil. Biol. 49: 37-48.

PAGANO, S. N.; CESAR, O. \& LEITÃO-FILHO, H. de. 1989b. Estrutura fitossociológica do estrato arbustivo-arbóreo da vegetação de cerrado da Área de Proteção Ambiental (APA) de Corumbataí, SP. Revta. Bras. Biol. 49: 49-59.

PICOLLO, A. L. G.; THOMAZINI, L. I.; MASSA, C. S.; CESAR, O.; PAGANO, S. N.; MORAES, A. P. V. \& AMARAL, H. 1971. Aspecto fitossociológico de uma reserva de cerrado. Revta. Agric. 46: 81-92.

PIJL, L. van der. 1972. Principles of dispersal in higher plants. Berlin, Springer-Verlag.

RATTER, J. A. 1980. Notes on the vegetation of Fazenda Água Limpa (Brasília - DF, Brasil). Edinburgh, Royal Botanical Garden.

RATTER, J. A. 1992. Transitions between cerrado and forest vegetation in Brazil. In: FURLEY, P. A.; PROCTOR, J. \& RATTER, J. A. (ed). Dynamics of forest-savanna boundaries. London, Chapman \& Hall.

RAUNKIAER, C. 1934. The life forms of plants and statistical geography. Oxford, Claredon. RIBEIRO, J. F, SILVA, J. C. S \& BATMANIAN, G. J. 1985. Fitossociologia de tipos fisionômicos de cerrado em Planaltina, D.F. Revta. Bras. Bot. 8(2): 131-42.

RIZZINI, C. T. 1963. A flora do cerrado. In: FERRI, M. G. I Simpósio sobre o cerrado. São Paulo, EDUSP e Edgard Blücher. 
RIZZINI, C. T. 1971. Árvores e arbustos do cerrado. Rodriguésia 38: 63-77.

RIZZINI, C. T. 1979. Tratado de fitogeografia do Brasil: aspectos ecológicos. São Paulo, HUCITEC e EDUSP.

RODRIGUES, W. A. 1971. Plantas dos campos de Rio Branco (Território de Roraima). In: FERRI, M. G. (coord). III Simpósio sobre cerrado. São Paulo, Edgard Blücher e EDUSP.

SHIDA, C. N. Em andamento. A ocupação humana no entorno da ARIE Cerrado Pé-de-Gigante (Santa Rita do Passa Quatro, SP) e sua influência sobre os ecossitemas naturais. Dissertação de Mestrado. Univ. S. Paulo.

SILBERBAUER-GOTTSBERGER, I; MORAWETZ, W. \& GOTTSBERGER, G. 1977. Frost damage of cerrado plants in Botucatu, Brazil, as related to the geographical distribution of the species. Biotropica 9: 253-61.

STELLFIELD, C. 1950. Fitogeografia do estado do Paraná. Archos Mus. Paran. 7: 309-49.

TAKEUCHI, M. 1960. The structure of amazonian vegetation. I - Savanna in northern Amazon. $J$. Fac. Sci. Tokio Univ. sect. 3, Botany 7: 523-33.

TOLEDO FILHO, D. V. 1984. Composição florística e estrutura fitossociológica da vegetação de cerrado no município de Luiz Antônio (SP). Tese de Mestrado. Univ. Est. Campinas.

TOLEDO FILHO, D. V.; LEITÃO FILHO, H. de F. \& RODRIGUES, T. S. 1984. Composição florística de área de cerrado em Moji Mirim (SP). Bol. Técn. IF 38: 165-75.

TROPPMAIR, H. 1974. A cobertura vegetal primitiva do estado de São Paulo baseada em estudos toponímicos, históricos e ecólogicos. Ciênc. Cult. 26: 240-3.

TRYON, R.M. \& TRYON, A.F. 1982. Ferns and allied plants with special reference to Tropical America. Springer-Verlag, New York.

VELOSO, H. P. 1964. Os grandes clímaces do Brasil. III: Considerações gerais sobre a vegetação do Centro-Oeste. Mem. Inst. Osw. Cruz 61: 357-70. 
VINCENT, R. de C., MIYAZAKI, S.L., GOMES, E.P.C. \& MANTOVANI, W. 1992. Estrutura e composição florística do cerrado de Emas, Pirassununga, SP. In: CONGR. SBSP 8, Campinas, 1990. Anais. Soc. Bot. S. Paulo, p.139-151.

WARMING, E. 1892. Lagoa Santa, contribuição para a geografia fitobiológica. In: WARMING, E. \& FERRI, M. G. 1973. Lagoa Santa e a vegetação dos cerrados brasileiros. Belo Horizonte, Itatiaia; São Paulo, EDUSP.

WHITTAKER, R. H. 1977. Evolution of species diversity in land communities. In: HECHT, M. K.;

STEERE, W. C. \& WALLACE, B. (eds). Evolutionary biology. Plenum Press, New York. 


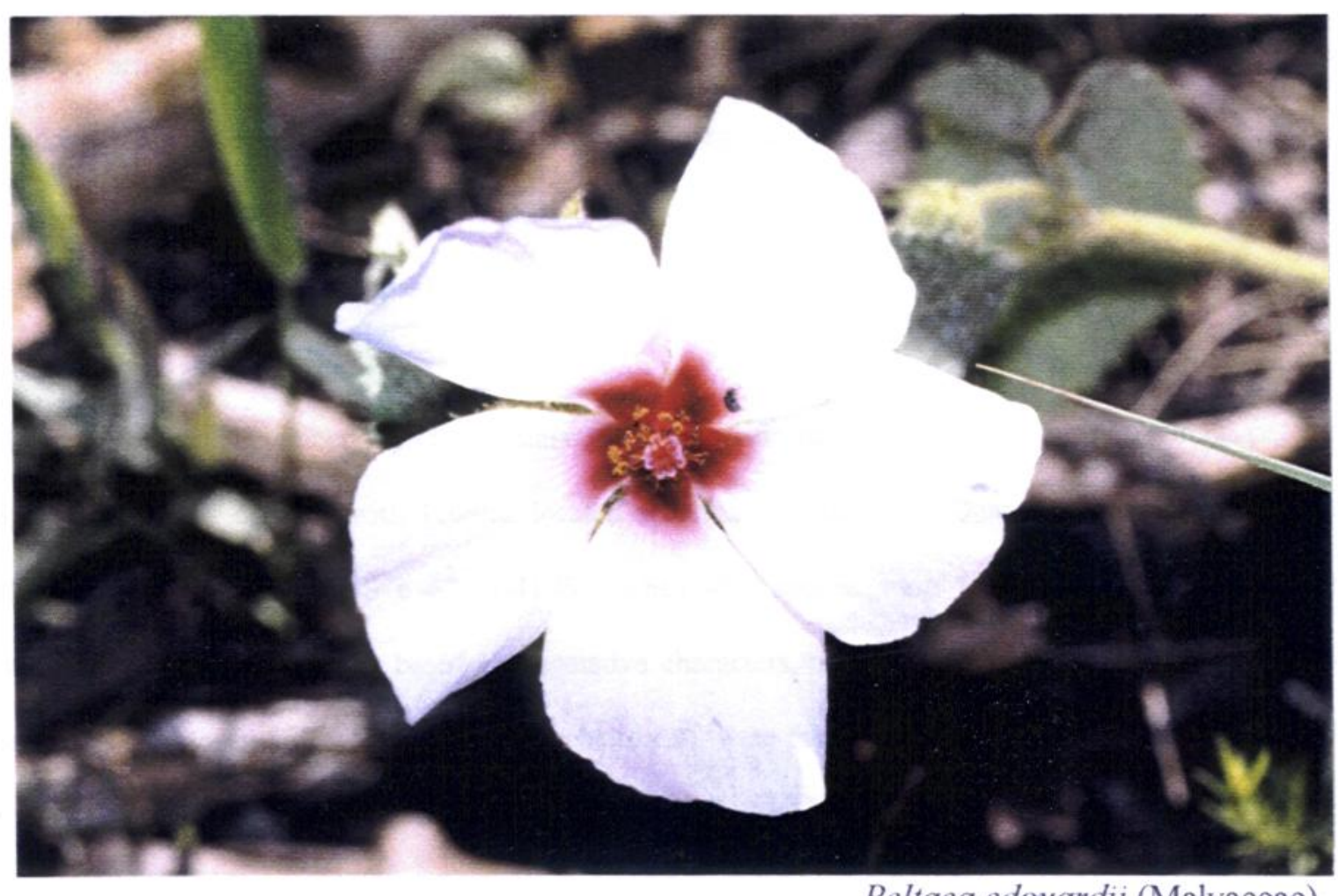

Peltaea edonardii (Malvaceae) 


\section{Chaves de identificação das espécies vegetais vasculares baseada em caracteres vegetativos para a ARIE Cerrado Pé-de-Gigante (Santa Rita do Passa Quatro, SP).}

Resumo - Entre setembro de 1995 e fevereiro de 1997, efetuou-se um levantamento florístico em uma área de vegetação natural, composta principalmente por cerrado, de 1269ha, situada no munícipio de Santa Rita do Passa

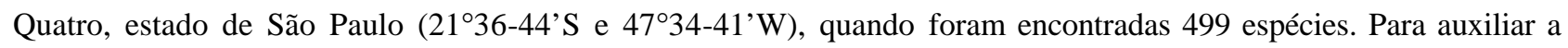
identificação destas espécies, construiram-se chaves indentadas baseadas em caracteres vegetativos para as formações de cerrado "sensu lato", campo úmido, mata ciliar e floresta estacional semidecídua. Alguns passos das chaves foram ilustrados por figuras e um glossário de alguns termos empregados foi incluído.

Palavras-chave: cerrado, savana, flora vascular, Pé-de-Gigante

Abstract - From September 1995 to February 1997, a floristic survey was carried out in a natural vegetation area, composed mainly by cerrado, with 1269 ha, located at Santa Rita do Passa Quatro municipality, São Paulo State,

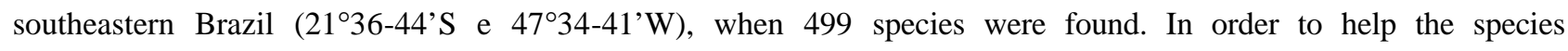
identification, four indented keys based on vegetative characters, one for each vegetation type (cerrado, floodplain grassland, gallery forest and seasonal semidecidous forest), were constructed. Some steps in the keys were illustrated by figures and a glossary was also included.

Key words: cerrado, savanna, vascular flora, southeastern Brazil

\section{Introdução}

Como as espécies não florescem durante todo o ano, uma chave de identificação baseada em caracteres vegetativos traz a vantagem de poder ser utilizada em qualquer época do ano, por pesquisadores das mais diversas áreas de atuação.

Chaves baseadas em caracteres vegetativos para identificação de espécies de plantas em diversas 
formações foram construídas por Veloso (1945), em Teresópolis, RJ, e por Veloso (1946), em Ilhéus, BA, para áreas de floresta pluvial atlântica; Mantovani et al. (1985) e Mantovani (1987), em Mogi-Guaçu, SP, em região de cerrado; Rossi (1994), Garcia (1995) e Aragaki (1997), todos em São Paulo, SP, em áreas de transição entre os domínios da floresta estacional semidecídua e da floresta pluvial atlântica; e Batalha et al. (aceito para publicação), em Pirassununga, SP, em área de cerrado.

Estão sendo desenvolvidos vários projetos na Área de Relevante Interesse Ecólogico (ARIE) Cerrado Pé-de-Gigante, que fornecerão subsídios ao seu plano de manejo (Capítulo 1). Com esta chave, espera-se facilitar a identificação rápida e segura das espécies vasculares de plantas encontradas por pesquisadores que venham a trabalhar nesta reserva.

\section{Material e métodos}

\section{Área de estudo}

A Área de Relevante Interesse Ecólogico (ARIE) Cerrado Pé-de-Gigante está localizada no município de Santa Rita do Passa Quatro, estado de São Paulo, entre as coordenadas 21³6-44'S e 47³4-41'W, sob clima Cwag' de Köppen, em cotas altimétricas de 660 a 730m e sobre latossolo Vermelho-Amarelo fase arenosa (Castro 1987). A área estudada possui 1269ha, dos quais 1060ha constituem a ARIE Cerrado Pé-de-Gigante. Em seu interior, existem variações fisionômicas de cerrado que vão desde o campo sujo ao cerradão, além de mata ciliar, floresta estacional semidecídua e campo de várzea. Para uma caracterização mais detalhada da área, ver o Capítulo 1.

\section{Metodologia}


Entre setembro de 1995 e fevereiro de 1997, efetuou-se no local um levantamento florístico (Capítulo 2). Neste levantamento, foram realizadas excursões de coleta mensais, com 3 ou 4 dias de duração cada, quando os espécimes de plantas vasculares em fase reprodutiva foram amostrados em caminhadas assistemáticas.

O levantamento florístico indicou a existência de 499 espécies, distribuídas em 316 gêneros e 107 famílias (Capítulo 2). O material foi depositado no herbário "Maria Eneyda P. K. Fidalgo" do Instituto de Botânica de São Paulo (SP), com duplicatas nos herbários do Instituto Florestal (SPSF) e do Departamento de Botânica do Instituto de Biociências da Universidade de São Paulo (SPF).

A partir do material coletado, foram construídas chaves indentadas baseadas em caracteres vegetativos, para as seguintes formações: cerrado "sensu lato", campo úmido, mata ciliar e floresta estacional semidecídua. Tais chaves foram baseadas naquelas de Mantovani et al. (1985), de Mantovani (1987) e de Batalha et al. (aceito para publicação). Foram utilizadas características observadas em espécimes adultos, evitando-se variações em indivíduos jovens e plântulas. Para auxiliar a identificação e conceituar os termos empregados, alguns passos da chave foram ilustrados por figuras e um glossário foi incluído. Os termos empregados na elaboração das chaves e no glossário seguiram os conceitos de Ferri et al. (1969), Radford et al. (1974), Rizzini (1977) e Mantovani et al. (1985).

As espécies foram classificadas em formas de vida segundo o sistema de Raunkiaer (1934), adaptado por Mueller-Dombois \& Ellenberg (1974), conforme Anexo (p.116). Foram consideradas como pertencentes ao componente herbáceo-subarbustivo as espécies caméfitas, epífitas, hemicriptófitas, geófitas, terófitas, lianas, parasitas e semi-parasitas vasculares, e ao componente arbustivo-arbóreo, as caméfitas que possam atingir $2 \mathrm{~m}$ de altura na estação chuvosa e as fanerófitas.

Para uma identificação segura, não se deve considerar ramos de brotamento e ramos com galhas ou doenças devido às grandes variações de forma e textura. Durante a coleta, deve-se anotar 
características que serão perdidas no material herborizado, como hábito de crescimento, odor e coloração das folhas, presença de látex e características do sistema subterrâneo.

\section{Resultados}

\section{- cerrado "sensu lato"}

1. Árvores ou arbustos (caméfitas que atinjam $2 \mathrm{~m}$ alt. na estação chuvosa ou fanerófitas)

2. Monocotiledôneas (Arecaceae)

3. Segmentos foliares equiidistantes, base da raque com fibras lineares persistentes

Butia paraguayensis

3'. Segmentos foliares dispostos em fascículos, base da raque sem fibras ou com fibras caducas

4. Estipe com mais de $5 \mathrm{~m}$ alt

Syagrus romanzoffiana

4'. Estipe com até $2 \mathrm{~m}$ alt. Syagrus flexuosa

2'. Dicotiledôneas (outras famílias)

5. Folhas compostas

6. Folhas digitadas

7. Folhas alternas

8. Folíolos não articulados (Figura 3.1)

Pseudobombax longiflorum

8'. Folíolos articulados

9. Folíolos glabros, concolores

Eriotheca gracilipes

9'. Folíolos pilosos na face inferior, discolores.

Didymopanax vinosum

7'. Folhas opostas

10. Folíolos glabros

11. Folíolos oblongos, peciolados

Tabebuia aurea

11 '. Folíolos elíticos, sésseis

10'. Folíolos pilosos

12. Folíolos elíticos, pilosidade amarelada

Zeyhera montana

12'. Folíolos obovais; pilosidade ocrácea

6'. Folhas pinadas, ternadas ou bipinadas

13. Folhas bipinadas

14. Folhas opostas

14'. Folhas alternas

15. Folhas com 2 a 3 -jugas, foliólulos com nervura amarelada

15 '. Folhas multijugas, foliólulos com nervuras esverdeadas

16. Folíolos oblongos

17. Folíolos densamente pilosos, com mais de 10 pares de folíolos

Dimorphandra mollis

17'. Folíolos esparsamente pilosos, com 4 a 8 pares de folíolos Plathymenia reticulata

16'. Folíolos linear-lanceolados, circulares, ovais, frequientemente assimétricos

18. Folíolos com mais de 40 foliólulos, linear-lanceolados, de até $1 \mathrm{~cm}$ compr., sem domáceas

19. Tronco rugoso; folíolos com menos de $0,5 \mathrm{~cm}$ compr

Anadenanthera peregrina

19'. Tronco suberoso; folíolos com 0,7 a $1 \mathrm{~cm}$ compr. Anadenanthera falcata

18'. Folíolos com 10 a 16 foliólulos, circulares, ovais, maiores que $2 \mathrm{~cm}$ compr., com domáceas na face inferior

20. Foliólulos circulares

Stryphnodendron adstringens

20'. Foliólulos ovais ou oblongos Stryphnodendron polyphyllum

13'. Folhas pinadas ou ternadas

21. Folhas com 2 (aparentemente 1, em Bauhinia) a 4 folíolos

22. Folhas bifolioladas

23. Folíolos soldados entre si, simulando folha simples Bauhinia rufa 
23'. Folíolos livres entre si.

Hymenaea stignocarpa

22'. Folhas com 3 ou 4 folíolos

24. Filotaxia oposta, folhas com 3 folíolos, margem denteada.

Caryocar brasiliense

24'. Filotaxia alterna, folhas com 4 folíolos, margem inteira... Senna rugosa

21 '. Folhas com 5 ou mais folíolos (raramente 3 )

25. Raque foliar terminada em pequeno apêndice (Figura 3.2)

26. Folhas com 6 a 11 folíolos

Magonia pubescens

26'. Folhas com mais de 13 folíolos . Platypodium elegans

25'. Sem este caráter

27. Folhas paripinadas

28. Folhas com 6 a 8 folíolos (raramente 10 em Copaifera)

29. Folíolos com ápice cuspidado, sem pontuações translúcidas no limbo, peciólulo escurecido

Dyptichandra aurantiaca

29'. Folíolos com ápice obtuso, com pontuações translúcidas no limbo, peciólulo indistinto.

Copaifera langsdorfii

28'. Folhas com 10 ou mais folíolos

30. Folíolos alternos, ápice emarginado

Platypodium elegans

30'. Folíolos opostos, ápice obtuso ou agudo

31. Folíolos glabros, base obtusa.

Sclerolobium paniculatum

31'. Folíolos pilosos, base aguda. Senna sylvestris

27'. Folhas imparipinadas

32. Folíolos pilosos

33. Folhas com mais de 11 folíolos, oblongo ou lanceolados

34. Folíolos oblongos, com mais de $5 \mathrm{~cm}$ compr. e $2 \mathrm{~cm}$ larg., nervura central imersa na face superior

Bowdichia virgilioides

34'. Folíolos lanceolados, com até $4 \mathrm{~cm}$ compr. e $1.5 \mathrm{~cm}$ larg., nervura central saliente na face superior

Pterodon pubescens

33'. Folhas com 5 a 9 folíolos, ovais ou elíticos

35. Pilosidade verde-esbranquiçada em ambas as faces dos folíolos e nos ramos jovens, folhas com 5 a 7 folíolos (raramente 3 )

Acosmium dasycarpum

35'. Pilosidade albo-ferrugínea na face inferior dos folíolos e ferrugínea nos ramos jovens, folhas com 7 a 9 folíolos

36. Base dos folíolos cordada, nervura central saliente somente na face inferior

Connarus suberosus

36'. Base dos folíolos obtusa ou cuneada, nervura central saliente em ambas as faces

Rourea induta

32'. Folíolos glabros

37. Folhas com 11 ou mais folíolos

38. Folíolos com estipelas.....

Andira anthelmia

38'. Folíolos sem estipelas

39. Folíolos ovais, ápice agudo..... Machaerium acutifolium

39'. Folíolos largo-ovais ou oblongos, ápice obtuso ou emarginado

40. Folíolos largo-ovais.

Dalbergia miscolobium

40'. Folíolos oblongos.. Bowdichia virgilioides

37 '. Folhas com até 9 folíolos

41. Folíolos com estipelas.

Andira anthelmia

41'. Folíolos sem estipelas

42. Folíolos odoríferos, caule liso ou rugoso

43. Folíolos de base aguda, ramos jovens pubescentes

43'. Folíolos de base freqüentemente obtusa ou assimétrica, ramos jovens glabros

Tapirira guianensis

42'. Folíolos não-odoríferos, caule suberoso

Protium heptaphyllum

44. Folíolos elíticos ou oblongos

Vatairea macrocarpa

44'. Folíolos ovais ou lanceolados

45. Folhas com 5 a 7 folíolos ovais, ramos jovens pilosos

Acosmium dasycarpum

45'. Folhas com 7 a 9 folíolos lanceolados, ramos jovens glabros. Acosmium subelegans

5'. Folhas simples

46. Folhas alternas

47. Plantas latescentes

48. Folhas laxas 
49. Plantas com látex aquoso, escasso (observar a nervura central); ramos avermelhados

Vernonia rubriramea

49'. Plantas com látex leitoso, abundante; ramos não avermelhados

50. Folhas pilosas..

Brosimum gaudichaudii

50 '. Folhas glabras

51. Estípula terminal recobrindo a gema apical

Ficus citrifolia

51'. Estípula terminal ausente

52. Folhas oblanceoladas, nervuras secundárias esverdeadas.

Kielmeyera variabilis

52'. Folhas elíticas ou oblongas, nervuras secundárias amareladas na face inferior...... Pouteria ramiflora

48'. Folhas congestas no ápice dos ramos

53. Ramos com ápice albo-tomentoso.

Aspidosperma tomentosum

53'. Ramos com ápice glabro ou ferrugíneo tomentoso

54. Folhas pecioladas, gema apical ferrugíneo-tomentosa

55. Folhas elíticas ou oblongas, glabras; córtex avermelhado

Pouteria ramiflora

55'. Folhas obovais, pilosas; córtex esbranquiçado Pouteria torta

54'. Folhas sésseis, gema apical glabra

56. Folhas jovens avermelhadas ou rosadas, menores que $10 \mathrm{~cm}$ compr. quando adultas

56 '. Folhas jovens esverdeadas, maiores que $10 \mathrm{~cm}$ compr. quando adultas

57. Folhas largo-obovais, com nervuras saliente na face inferior.

Kielmeyera rubriflora

57'. Folhas obovais ou oblanceoladas, com nervuras imersas

58. Folhas obovais, verde-azuladas, com cerca de $20 \mathrm{~cm}$ compr. e $9 \mathrm{~cm}$ larg.

Himatanthus obovata

58'. Folhas oblanceoladas, verde-escuras, com cerca de $15 \mathrm{~cm}$ compr. e de 3 a $5 \mathrm{~cm}$ larg.

Kielmeyera variabilis

47'. Plantas não latescentes

59. Folhas pilosas

60. Folhas adultas pilosas em ambas as faces

61. Folhas com pêlos escabrosos na face superior, nervuras impressas, margem serrilhada

61 '. Folhas com pilosidade sedosa, nervuras imersas ou salientes, margem inteira

62. Folhas dísticas.

62'. Folhas espiraladas

Xylopia aromatica

63. Folhas elíticas, pilosidade esbranquiçada, limbo foliar com até $8 \mathrm{~cm}$ compr. e $3 \mathrm{~cm}$ larg.Vanillosmopsis erythrol

63'. Folhas obovais ou oblongas, pilosidade ferrugínea, limbo foliar com mais de $12 \mathrm{~cm}$ compr. e $8 \mathrm{~cm}$ larg Diospyros hispida

60 '. Folhas adultas pilosas apenas na face inferior ou na margem

64. Folhas de margem crenulada ou serreada Luehea divaricata

64'. Folhas de margem inteira

65. Caule liso

66. Indumento de pêlos lepidotos.

66'. Indumento de pêlos simples

67. Folhas dísticas, base revoluta, axilas das nervuras sem domáceas

Duguetia furfuracea

67'. Folhas não dísticas, base plana, axilas das nervuras com domáceas de pêlos.

Xylopia aromatica

5'. Caule rugoso ou suberoso

68. Pilosidade ferrugínea

69. Folhas coriáceas, com até $15 \mathrm{~cm}$ compr., base aguda ou obtusa

Styrax ferrugineus

69'. Folhas cartáceas, com mais de $20 \mathrm{~cm}$ compr., base truncada ou cordada

68'. Pilosidade esbranquiçada

70. Folhas lanceoladas, córtex avermelhado Virola sebifera

70'. Folhas circulares ou elíticas, córtex esverdeado

71. Folhas coriáceas, densamente pilosas, sem estípulas

Couepia grandiflora

71 '. Folhas rigido-coriáceas, esparsamente pilosas, com estípulas

Piptocarpha rotundifolia

59'. Folhas glabras

72. Presença de ramentas (Figura 3.3) no caule (Erythroxylaceae)

73. Caule liso ou rugoso

74. Folhas membranáceas, com até $5 \mathrm{~cm}$ de comprimento. Erythroxylum cuneifolium

74'. Folhas cartáceas, com mais de $8 \mathrm{~cm}$ de comprimento. Erythroxylum campestre

73'. Caule suberoso

75. Folhas oblanceoladas, base cuneada, maiores que $15 \mathrm{~cm}$ compr.

Erythroxylum tortuosum

$75^{\prime}$. Folhas oblongas, obovais ou elíticas, base aguda ou obtusa, menores que $10 \mathrm{~cm}$ 
(raramente até $15 \mathrm{~cm}$ ) compr. comprimento

76. Folhas de base aguda, dispostas em ramos rugosos ou suberosos, pecíolos maiores que $0,4 \mathrm{~cm}$ de comprimento Erythroxylum suberosum

76'. Folhas de base obtusa, dispostas em ramos lisos, pecíolos de até $0,2 \mathrm{~cm}$ de comprimento.

Erythroxylum campestre

72'. Ausência de ramentas

77. Margem foliar inteira

78. Pulvino e pulvínulo presentes

Bauhinia rufa

78'. Pulvino e pulvínulo ausentes

79. Ápice foliar emarginado ou obtuso

80. Folhas dísticas

81. Folhas cartáceas, obovais ou elíticas, pilosas em ambas as faces, sem domáceas

81'. Folhas coriáceas, ovais, pilosas apenas na face inferior, com domáceas saculiformes na axila das nervuras na face inferior

Annona crassiflora

'. Folhas espiraladas

82. Plantas sobolíferas; folhas obovais

Annona coriacea

82'. Plantas arbustivas; folhas elíticas ....

Anacardium humile

79'. Ápice foliar cuspidado ou agudo

83. Ápice foliar cuspidado, pecíolo maior que $1 \mathrm{~cm}$ compr

84. Folhas elíticas

84'. Folhas largo-elíticas.

Ocotea corymbosa

83 '. Ápice foliar agudo, pecíolo de até cerca de $0,5 \mathrm{~cm}$ compr. (raramente até $1 \mathrm{~cm}$ )

85. Folhas lanceoladas, dísticas, base obtusa .....

85'. Folhas ovais, oblongas ou elíticas, espiraladas, base aguda

86. Folhas ovais ou oblongas, com dois nectários extra-florais na face inferior do limbo (Figura 3.4)

Tontelea micrantha

86'. Folhas elíticas, sem nectários extra-florais Bredemeyera floribunda

77'. Margem foliar serreada ou denteada

87. Base foliar assimétrica, limbo com pontuações translúcidas (olhar contra a luz)

88. Folhas com pilosidade na face inferior apenas ao longo da nervura central ...

Casearia sylvestris

88 '. Folhas com pilosidade em toda a face inferior

Casearia grandiflora

87'. Base foliar simétrica, limbo sem pontuações translúcidas

89. Folha de base obtusa ou cordada

90. Folhas cartáceas ou membranéceas, cladódromas, base obtusa

Austroplenckia populnea

90'. Folhas coriáceas, eucamptódromas, base cordada ou aguda

91. Base cordada, margem serreada

Ouratea spectabilis

91'. Base aguda, margem inciso-serreada.

Ouratea castaneaefolia

89 '. Folha de base aguda ou decorrente

92. Ápice foliar cuspidado, pecíolo maior que $2 \mathrm{~cm}$ compr.

93. Folha cartácea, base aguda

Austroplenckia populnea

93'. Folha coriácea, base longo-cuneada. Roupala montana

92'. Ápice foliar agudo, pecíolo menor que $1 \mathrm{~cm}$ compr.

94. Plantas com látex escasso (observar a nervura central); ramos avermelhados; folhas com margem serrilhada em todo o limbo. Vernonia rubriramea

94'. Plantas sem látex; ramos esverdeados ou amarronzados; folhas com margem serrilhada ou serreada na metade superior do limbo.

Baccharis dracunculifolia

46'. Folhas verticiladas ou opostas

95. Folhas verticiladas

96. Base do pecíolo com glândula (Figura 3.5).

Qualea parviflora

96'. Base do pecíolo sem glândula

97. Presença de estípulas interpeciolares (olhar ramos jovens)

Amaioua guianensis

97'. Ausência de estípulas interpeciolares

98. Limbo foliar sem pontuações translúcidas e folhas não aromáticas

99. Folhas glabras, até $10 \mathrm{~cm}$ compr.

Vochysia tucanorum

99'. Folhas pilosas, com mais de $12 \mathrm{~cm}$ compr. Vochysia cinamommea

98'. Limbo foliar com pontuações translúcidas (olhar contra a luz) e/ou folhas aromáticas

100. Folhas amareladas

Eugenia aurata

100'. Folhas não amareladas

101. Margem do limbo foliar amarelada

Eugenia livida 
101'. Margem do limbo foliar indistinta

102. Folhas obovais ou oblongas, base aguda, nervuras impressas na face inferior.

102 '. Folhas ovais, base cordada, nervuras salientes na face inferior

... Myrcia lingua Myrcia lasiantha

95'. Folhas opostas

103. Plantas latescente.

Hancornia speciosa

103'. Plantas não latescentes

104. Base do pecíolo com glândula (Figura 3.5)

105. Folhas largo-ovais .....

Qualea dichotoma

105 '. Folhas elíticas, oblongas ou obovais

106. Tronco liso ou rugoso, limbo foliar de 10 a $15 \mathrm{~cm}$ compr.

Qualea multiflora

106'. Tronco evidentemente suberoso

107. Base foliar freqüentemente cordada, limbo de 13 a $18 \mathrm{~cm}$ compr.

Qualea grandiflora

107'. Base foliar obtusa, limbo de 7 a $9 \mathrm{~cm}$ compr.

Qualea parviflora

104'. Base do pecíolo sem glândula

108. Presença de estípulas interpeciolares (olhar ramos jovens)

109. Folhas pilosas

110. Base foliar obtusa ou aguda, margem revoluta, face superior do limbo bulada

110'. Base foliar atenuada ou aguda, margem plana, face superior do limbo lisa

111. Folhas largo-elíticas, pilosas em ambas as faces ...

Rudgea viburnoides

111 '. Folhas elíticas, pilosas apenas na face inferior.

Tocoyena formosa

109'. Folhas glabras

112. Folhas elíticas, menores que $10 \mathrm{~cm}$ compr.

Amaioua guianensis

112 '. Folhas obovais ou oblongas, maiores que $15 \mathrm{~cm}$ compr.

113. Folhas sésseis, rígido-coriáceas, com nervuras e veias amarelas.....

113'. Sem o conjunto de caracteres

114. Folhas largo-obovais, ápice foliar obtuso ou mucronado.

Alibertia sessilis

114'. Folhas largo-oblongas, ápice foliar cuspidado

Palicourea rigida

. Ausência de estípulas interpeciolares

115. Folhas acródromas

116. Folhas glabras

116'. Folhas pilosas

117. Pilosidade amarelada na face inferior do limbo

117'. Pilosidade esbranquiçada ou ferrugínea

118. Folhas discolores, com pilosidade esbranquiçada

119. Folhas jovens (no ápice dos ramos) pilosas em ambas as faces, seção transversal dos ramos jovens cilíndrica, sem arestas....

Miconia albicans

119'. Folhas jovens (no ápice dos ramos) glabras na face superior, seção transversal dos ramos jovens quadrangular, com arestas evidentes.

118'. Folhas concolores, com pilosidade não-esbranquiçada

120. Ramos quadrangulares. Miconia stenostachya

120'. Ramos cilíndricos

121. Face superior do limbo foliar bulada, base cordada, pilosidade patente, amarelada

Leandra lacunosa

121'. Face superior do limbo foliar não bulada, base obtusa, pilosidade flocosa, ferrugínea Miconia rubiginosa

115'. Folhas não acródromas

122. Ápice foliar com glândula na face inferior (Figura 3.6)

Lafoensia pacari

122'. Ápice foliar sem glândula

123. Gema apical recoberta por pilosidade ferrugínea.

Guapira noxia

123'. Sem essa característica

124. Estípulas intrapeciolares presentes (Figura 3.7)

125. Folhas pilosas, congestas nos ápices dos ramos

126. Pilosidade apenas na face inferior....

Byrsonima crassa

126'. Pilosidade em ambas as faces

125'. Folhas glabras, laxas

127. Folhas largo-ovais, com ápice obtuso

127 '. Folhas elíticas, com ápice agudo Byrsonima verbascifolia

124'. Estípulas intrapeciolares ausentes

128. Margem foliar recortada

Byrsonima coccolobifolia Byrsonima intermedia 
129. Folhas não odoríferas, base aguda .....

Peritassa campestris

129'. Folhas odoríferas, base obtusa ou cordada Lippia salviifolia

128'. Margem foliar inteira

130. Presença de nectários extra-florais na face inferior do limbo foliar, próximos à base.

Aegiphila lhotzkiana

130'. Ausência de nectários extra-florais

131. Ramos jovens de cor verde; folhas com odor desagradável, muito forte, limbo foliar com ápice foliar acuminado e base obtusa.....

Siparuna guianensis

131'. Sem o conjunto de caracteres

132. Limbo foliar sem pontuações translúcidas, folhas não aromáticas

133. Folhas com veias e nervuras secundárias não evidentes, limbo de cor verde-azulada ..... Neea theifera

133'. Folhas com veias e nervuras secundárias evidentes, limbo de cor verde

134. Folhas pilosas na face inferior (pilosidade ferrugínea)..... Heteropteris byrsonimifolia 134'. Folhas glabras

Tontelea micrantha

132'. Limbo foliar com pequenas pontuações translúcidas (olhar contra a luz)

e/ou folhas aromáticas

135. Margem do limbo foliar distinta, amarelada e translúcida

136. Folhas obovais, até $3 \mathrm{~cm}$ larg.

Eugenia punicifolia

136'. Folhas oblongas, elíticas ou largo-ovais, mais de $5 \mathrm{~cm}$ larg.

137. Folhas oblongas ou elíticas, base do limbo obtusa ....................Eugenia bimarginata

137'. Folhas largo-ovais, base do limbo cordada .......................................... Eugenia livida

135'. Margem do limbo foliar indistinta

138. Folhas glabras

139. Folhas ovais, sésseis, base cordada ......

Myrcia uberavensis

139'. Folhas elíticas, pecioladas, base obtusa

140. Limbo foliar até $5 \mathrm{~cm}$ compr.

Eugenia hiemalis

140 '. Limbo foliar maior que $10 \mathrm{~cm}$ compr. . Myrcia pubipetala

138'. Folhas pilosas, pelo menos na face inferior (olhar tangencialmente)

141. Folhas ovais, limbo foliar com base obtusa, pilosidade serícea argêntea e adpressa à face inferior do limbo

142. Limbo foliar até $4 \mathrm{~cm}$ compr.

Myrcia bella

142'. Limbo foliar com mais de $5 \mathrm{~cm}$ compr.

Myrcia lasiantha

$141^{\prime}$. Folhas não ovais, limbo foliar com base aguda, pilosidade de outros tipos

143. Folhas com ápice obtuso a emarginado, pilosidade ferrugínea na face inferior do limbo

144. Nervuras marginais evidentes (olhar na face superior do limbo), nervuras secundárias imersas na face inferior do limbo .....

144'. Nervuras marginais não evidentes, nervuras secundárias

proeminentes na face inferior do limbo .......................................

Myrcia lingua

145. Folhas obovais ou oblongas, pilosidade tomentosa alboferrugínea na face inferior do limbo foliar.

Myrcia tomentosa

$145^{\prime}$. Folhas elíticas ou largo-elíticas, pilosidade esbranquiçada na face inferior do limbo

146. Folhas largo-elíticas, nervuras imersas na face superior, folhas pubérulas na face inferior

Campomanesia pubescens

146'. Folhas elíticas, nervuras salientes na face superior, folhas

tomentosas na face inferior

1'. Ervas ou subarbustos (caméfitas, epífitas, hemicriptófitas, terófitas, lianas, parasitas vasculares ou Eugenia langsdorfii

semi-parasitas vasculares)

147. Samambaias (Pteridophyta)

148. Lâminas bipinadas Adiantum fructuosum

148'. Lâminas pinatisectas ou bipinatsectas

149. Lâminas bipinatsecta, pilosas Anemia ferruginea

149'. Lâminas pinatsecta, glabras Polypodium latipes

147'. Angiospermas (Magnoliophyta)

150. Plantas áfilas

151. Plantas parasitas.

Cassytha americana 
151'. Plantas autotróficas

152. Epífitas; caule modificado em cladódio

Epiphyllum phyllanthus

152'. Terrestres; caule sem modificações. Crumenaria polygaloides

150'. Plantas com folhas desenvolvidas

153. Palmeiras (Arecaceae)

154. Estipe subterrâneo, segmentos foliares isolados

Attalea geraensis

154'. Estipe desenvolvido, segmentos foliares reunidos de 3 a 5

155. Segmentos foliares com até $0,5 \mathrm{~cm}$ larg., concolores

.Syagrus flexuosa

155'. Segmentos foliares com mais $1 \mathrm{~cm}$ larg., discolores Syagrus loefgrenii

153'. Outras famílias

156. Folhas com lígula (Poaceae) (Figura 3.8)

157. Folhas lanceoladas

158. Pêlos glandulosos presentes

Melinis minutiflora

158'. Pêlos glandulosos ausentes

159. Lâmina foliar serícea em ambas as faces

Ichnanthus sericeus

159'. Lâmina foliar não serícea

160. Margem da lâmina foliar amarelada

161. Lígula membranosa (Figura 3.9)

Echinolena inflexa

161'. Lígula pilosa (Figura 3.10).

Panicum procurrens

160'. Margem da lâmina foliar indiferenciada

162. Plantas decumbentes; lâmina foliar maior que $10 \mathrm{~cm}$ compr

162 '. Plantas eretas; lâmina foliar até $5 \mathrm{~cm}$ compr.

Brachiaria decumbens

157'. Folhas lineares ou linear-lanceoladas

163. Plantas glabras ou com pêlos somente nos nós

164. Lâmina foliar de até $5 \mathrm{~cm}$ compr.

Gymnpogon foliosus

164'. Lâmina foliar maior que $6 \mathrm{~cm}$ compr.

165. Nós pilosos

166. Margem da lâmina foliar amarelada, lâmina foliar com até $1,5 \mathrm{~cm}$ larg...........Tristachya leiostachya

166'. Margem da lâmina foliar indiferenciada, lâmina foliar com mais de $2 \mathrm{~cm}$ larg.....Panicum maximum 165 '. Nós glabros

167. Lígula membranosa (Figura 3.9)

168. Nós inferiores geniculados.

Setaria geniculata

168'. Sem essa característica

169. Plantas sem coloração avermelhada

Digitaria insularis

169'. Plantas com coloração avermelhada (olhar nós, folhas jovens, região do colar, lígula)

170. Folhas usualmente revolutas, lâmina foliar com até 3mm larg. ........ Andropogon leucostachys

170'. Folhas planas, lâmina foliar com mais de 5mm larg. Schyzachirium condensatum

167'. Lígula pilosa (Figura 3.10) ou nula

171. Base da lâmina foliar ciliada

172. Lâmina foliar de até $20 \mathrm{~cm}$ compr., bainhas glandulosas, ao menos na nervura mediana....

Eragrostis articulata

172'. Lâmina foliar maior que $30 \mathrm{~cm}$ compr., bainha eglandulosa. Loudetiopsis chrysothryx

171'. Base da lâmina foliar glabra

173. Região do colar enegrescida..................................................................................Aristida jubata

173'. Região do colar não enegrescida

174. Brotamento arroxeado, achatado

Chloris barbata

174'. Brotamento esverdeado ou amarelado, cilíndrico

175. Folhas revolutas Sporolobus indicus

175'. Folhas planas

176. Lâmina foliar de até $5 \mathrm{~mm}$ larg.

Eragrostis airoides

176'. Lâmina foliar com mais de $6 \mathrm{~mm}$ larg. Panicum olyroides

163'. Plantas pilosas

177. Planta robusta; colmo com $0,5-1 \mathrm{~cm}$ diâm. basal; nós, bainha e face dorsal da lâmina

foliar densamente pilosos; brotamento achatado, amarelado Axonopus barbigerus

177'. Sem o conjunto de caracteres

178. Nós pilosos

179. Brotamento achatado, amarelado; lígula membranosa (Figura 3.9), ciliada, pouco

desenvolvida. Axonopus marginatus

179'. Sem o conjunto de caracteres 
180. Plantas procumbentes; folhas verdes, linear-lanceoladas $(0,5-1 \mathrm{~cm}$ larg.)

........................................................................................................ Rhynchelytrum repens

180'. Plantas eretas; folhas verde-azuladas, lineares (até $0,4 \mathrm{~cm}$ larg.) ............ Loudetiopsis chrysothrix 178'. Nós glabros

181. Lâmina foliar de até $20 \mathrm{~cm}$ compr.

182. Plantas com coloração avermelhada (olhar nós, folhas jovens, região do colar, lígula), bainha eglandulosa

Eragrostis maypurensis

182'. Plantas sem coloração avermelhada, bainhas glandulosas, ao menos na nervura mediana .

..Eragrostis articulata

181'. Lâmina foliar maior que $20 \mathrm{~cm}$ compr.

183. Plantas procubentes

Rhynchelytrum repens

183'. Plantas eretas

184. Folhas verde-azuladas, lineares (até $0,4 \mathrm{~cm}$ larg.)

Loudetiopsis chrysothryx

184 '. Folhas verdes, linear-lanceoladas (mais de $0,5 \mathrm{~cm}$ larg.)

185. Plantas anuais; margem da lâmina foliar glabra

185'. Plantas perenes; margem da lâmina foliar ciliada.

Panicum cayennensis

156'. Folhas sem lígula (outras famílias)

186. Folhas dispostas em rosetas basais

187. Folhas não paralelódromas, sem bainha

188. Folhas discolores

189. Folhas com margem crenada e ápice agudo

Chaptalia integerrima

189'. Folhas com margem íntegra e ápice obtuso

Vernonia cephalotes

188'. Folhas concolores

190. Folhas obovais, nervuras secundárias imersas

190'. Folhas ovais, elíticas ou lanceoladas, nervuras secundárias salientes na face inferior

191. Folhas ovais ou elíticas

Tallinum paniculatum

191'. Folhas lanceoladas

Elephantopus mollis

187'. Folhas paralelódromas, com bainha

192. Margem foliar espinescente

193. Folhas oblongas ou lanceoladas

193'. Folhas linear-lanceoladas

194. Espinhos recurvados, pretos.

194'. Espinhos incurvados, verdes

195. Folhas jovens frequientemente avermelhadas, lâmina maior que $3 \mathrm{~cm}$ larg., com pêlos lepidotos esbranquiçados ... Orthopappus angustifolius

195'. Folhas jovens verdes, lâmina menor que $3 \mathrm{~cm}$ larg., com pêlos lepidotos ferrugíneos.

Aechmea bromeliifolia

.. Dickia tuberosa

2' Margem foliar íntegra, serrilhada ou ciliada

196. Folhas filiformes ou revoluto-cilíndricas

197. Bainha foliar com mais de $5 \mathrm{~cm}$ larg.

197'. Bainha foliar com até $1 \mathrm{~cm}$ larg.

198. Folhas retas, ápice da bainha piloso Trimezia juncifolia

198'. Folhas curvas, ápice da bainha glabro

Bulbostylis hirtella

196'. Folhas lineares, lanceoladas ou obovais, planas

199. Epífitas

200. Folhas lanceoladas, sem escamas

Ionopsis paniculata

200'. Folhas lineares, com escamas esbranquiçadas..... Tillandsia geminiflora

199'. Terrestres

201. Lâmina foliar com três nervuras salientes, margem íntegra

Galeandra montana

201'. Lâmina foliar com a nervura central saliente, margem ciliada ou serrilhada

202. Folhas coriáceas, margem ciliada; seção do caule circular .

Eryngium junceum

202'. Folhas membranáceas, margem serrilhada; seção do caule triangular

203. Touceiras pauciperfilhadas; rizoma com crescimento linear....................... Cyperus cayennensis

203'. Touceiras multiperfilhadas; rizoma com crescimento multidirecional ........... Cyperus diffusus

186'. Folhas dispostas ao longo do caule

204. Folhas com a bainha desenvolvida, sem pecíolo, paralelódromas

205. Lâmina foliar ressupinada (Figura 3.11).

Alstroemeria pulchella

205'. Lâmina foliar não ressupinada

206. Caule com seção circular; folhas elíticas, margem íntegra

..Commelina erecta

206'. Caule com seção triangular; folhas lineares ou linear-lanceoladas, margem serrilhada 
207. Porção apical da bainha, oposta à inserção do limbo, exapendiculada . Rhynchospora exaltata

207'. Porção apical da bainha apendiculada (Figura 3.12) Scleria comosa 204'. Sem o conjunto de caracteres

208. Folhas compostas ou pinatífidas

209. Filotaxia oposta

210. Trepadeiras ou subarbustos com gavinhas

211. Subarbustos; folhas bipinadas ou pinadas

Memora peregrine

211'. Trepadeiras; folhas trifolioladas, um dos folíolos às vezes transformado em gavinha

212. Gavinha indivisa

213. Folíolos glabros

213'. Folíolos pilosos

214. Folíolos ovais, base aguda ou atenuada, peciólulo com mais de $1 \mathrm{~cm}$ compr.

14'. Folíolos elíticos, base cordada, peciólulo com menos de $0,5 \mathrm{~cm}$ compr

Cremastus pulcher

Arrabidaea craterophora

212'. Gavinha trífida no ápice

215. Pseudoestípulas foliáceas presentes

Anemopaegma chamberlaynii

215'. Pseudoestípulas ausentes

216. Folíolos pubescentes, sem pontuações glandulosas

Distictella mansoana

216'. Folíolos glabros, com pontuações glandulosas Pyrostegia venusta

210'. Plantas sem gavinhas

217. Folhas pinadas ou digitadas

218. Folhas pinadas, 2-folioladas (raro 1- ou 3-folioladas), folíolos actinódromos

218'. Folhas digitadas, 3 -folioladas, folíolos broquidódromos

Arrabidea brachypoda

217'. Folhas bipinadas

219. Folíolos glabros, raque foliar não alada. Anemopaegma arvense

219'. Folíolos pubescentes, raque foliar alada

220. Ala da raque foliolar formada pelo prolongamento dos foliólulos, margem foliolular íntegra. Jacaranda decurrens

220'. Ala da raque foliolar distinta dos foliólulos, margem foliolular serreada. Jacaranda rufa

209'. Filotaxia alterna

221. Folhas bipinadas

222. Trepadeiras; folíolos 3-foliolulados

223. Raque foliar alada

Paullinia elegans

223'. Raque foliar não alada

224. Folíolos com duas nervuras basais salientes, base formando um pseudo-pecíolo, limbo com pontuações translúcidas Serjania reticulata

224'. Folíolos sem duas nervuras basais salientes, base cuneada, limbo sem pontuações translúcidas Serjania lethalis

222'. Eretas ou prostradas; folíolos 2- a multijugos

225. Folhas 3- a multijugas

226. Planta armada (espinhos recurvados); ramos jovens e raque foliar velutinos; folhas multijugas.

Mimosa pigra

226'. Plantas inermes; ramos jovens e raque foliar híspidos; folhas 3- a 5-jugas.......Mimosa gracilis

225'. Folha 1- a 2-juga

227. Folíolos com três foliólulos desenvolvidos e um atrofiado

Mimosa debilis

227 ' Folíolos multifoliolulados Mimosa xanthocentra

$221^{\prime}$. Folhas pinadas ou digitadas

228. Folhas multifolioladas

229. Todos os folíolos pareados

230. Ramos em ziguezague; estípulas ovais; folíolos assimétricos, nervura central excêntrica Chaemaechrista flexuosa

230'. Ramos não em ziguezague; estípulas lineares; folíolos simétricos, nervura central mediana

231. Plantas pilosas (pêlos glandulosos); folha eglandulosa.

Chamaechrista cathartica

231'. Plantas glabras; folha com duas glândulas entre as duas primeiras jugas

Chamaechrista debilis

229'. Folíolos subopostos ou um folíolo terminal distinto 
232. Folíolos subopostos, folhas paripinadas

Aeschynomene marginata

232'. Folíolos opostos, folhas imparipinadas, com um folíolo distintamente terminal

233. Raque foliar alada, folíolos com margem crenada.

Serjania erecta

233'. Raque foliar não alada, folíolos com margem íntegra

234. Plantas sobolíferas

235. Folíolos elíticos, ápice e base agudos, peciolulados (peciólulo com mais de $0,5 \mathrm{~cm}$ compr.).

235'. Folíolos oblongos, ápice e base obtusos, subsésseis (peciólulo com menos de $0,5 \mathrm{~cm}$ compr.)

Talisia angustifolia

234'. Plantas escandentes, decumbentes ou eretas

236. Plantas escandentes; folíolos glabros...

Andira laurifolia

236'. Plantas decumbentes ou eretas; folíolos pilosos

237. Planta decumbente; folíolos de tamanho decrescente do ápice para a base, com até $2 \mathrm{~cm}$ compr.

Indigofera suffruticosa

237'. Planta ereta; folíolos de tamanho aproximadamente igual, com mais de $5 \mathrm{~cm}$ compr.

.Toulicia tomentosa

228'. Folhas 2- a 4- folioladas

238. Folhas paripinadas

239. Folhas unijugas

239'. Folhas bijugas

240. Estípulas lineares; folhas com pêlos glandulosos ou glândulas clavadas interjugas; folíolos simétricos

241. Plantas com pêlos glandulosos; sem glândulas clavadas interjugas

Chamaechrista campestris

241'. Plantas sem pêlos glandulosos; com glândulas clavadas interjugas (Figura 3.13)

Senna rugosa

240'. Estípulas cordiformes; folhas com glândulas plateliformes (Figura 3.14);

folíolos assimétricos

242. Folíolos largo-obovais, pilosos

Chamaechrista rotundifolia

242'. Folíolos oblanceolados ou oblongos, glabros .Chamaechrista desvauxii

238'. Folhas trifolioladas

243. Plantas trepadeiras

244. Folíolos linear-lanceolados, margem íntegra, glabros

244'. Folíolos ovais, elíticos ou obovais, margem serreada, pilosos

245. Folhas pecioladas (pecíolos de 1 a $2 \mathrm{~cm}$ compr.)

Cayaponia espelina

$245^{\prime}$. Folhas subsésseis (pecíolos até $0,5 \mathrm{~cm}$ compr.)

Cissus inundata

243'. Plantas eretas, prostradas ou volúveis (sem gavinhas)

246. Estípulas soldadas formando pseudo-bainha (Figura 3.15), folíolos com nervura marginal evidente (olhar face inferior)

247. Planta multifoliada, pubescente

247'. Planta paucifoliada, glabrescente.......

Stylosanthes guianensis

246'. Sem o conjunto de caracteres

248. Folhas digitadas (folíolos eqüidistantes)

249. Plantas volúveis

Centrosema venosum

249'. Plantas eretas

250. Folíolos sem estipelas, glabros

Crotalaria vitellina

250'. Folíolos com estipelas, pilosos. Clitoria laurifolia

$248^{\prime}$. Folhas pinadas

251. Plantas volúveis

252. Folíolos laterais simétricos

252'. Folíolos laterias assimétricos

253. Folhas hirsutas, truladas . Clitoria falcata

253'. Folhas tomentosas, largo-truladas

Macroptilium gracile

251'. Plantas eretas ou prostradas

254. Pecíolo mais curto ou de igual tamanho da raque foliar

255. Folíolos oblongos ou obovais, menores que $5 \mathrm{~cm}$ compr.

$255^{\prime}$. Folíolos ovais, maiores que $6 \mathrm{~cm}$ compr.

Eriosema crinitum

254'. Pecíolo maior que a raque foliar

256. Folhas com estípulas e estipelas, folíolos elíticos, maiores que $5 \mathrm{~cm}$ 
compr.

Periandra mediterranea

256'. Folhas sem estípulas ou estipelas, folíolos obovais, menores que $3 \mathrm{~cm}$

compr..

Oxalis physocallyx

208'. Folhas simples ou unifolioladas

257. Filotaxia alterna

258. Margem recortada (serreada, serrilhada, denteada, denticulada, crenada, crenulada ou

lobada) evidente

259. Folhas lobadas ou pinatífidas

260. Plantas trepadeiras

261. Plantas com três lobos estreito-elíticos, margem dos lobos íntegra

261 '. Plantas com lobos ovais, elíticos ou obovais, margem dos lobos denticulada

Cayaponia espelina

. Cissus sessilifolia

260'. Plantas eretas

262. Plantas aculeadas

Solanum palinacanthum

262'. Plantas inermes

263. Folhas 3-lobadas.

Manihot tripartita

263'. Folhas 4- ou 5-lobadas

264. Plantas com látex aquoso; margem dos lobos íntegra

264'. Plantas sem látex; margem dos lobos serreada

Manihot caerulescens

259'. Folhas não lobadas nem pinatífidas

265. Folhas glabras ou glabrescentes

266. Plantas trepadeiras; ramos quadrangulares

266'. Plantas não trepadeiras; ramos circulares

267. Folhas pecioladas

268. Plantas latescentes; base da lâmina foliar com glândulas (Figura 3.16)

268'. Plantas não ou pouco latescentes; base da lâmina foliar sem glândulas

269. Lâmina foliar com pontuações glandulosas, base assimétrica ....

269'. Lâmina foliar sem pontuações translúcidas, base simétrica

270. Plantas com látex escasso (observar na nervura principal); ramos jovens avermelhados; folhas elíticas

Vernonia rubriramea

270'. Plantas sem látex; ramos jovens não avermelhados; folhas oblongas

267'. Folhas sésseis ou subsésseis

Sebastiania serrulata

271. Folhas acródromas.

Baccharis dracunculifolia

271'. Folhas com outros tipos de nervação

272. Folhas amplexicaule, dimorfas (basais arredondadas, terminais lanceoladas).

Emilia coccinea

272'. Folhas não amplexicaule, isomorfas

273. Folhas lineares, hifódromas

Baccharis rufescens

273'. Folhas não lineares, eucamptódromas ou reticulódromas

274. Plantas com látex escasso (observar na nervura principal); ramos jovens avermelhados; base foliar aguda ou cuneada

Vernonia rubriramea

274'. Plantas sem látex; ramos jovens não avermelhados; base foliar cordada ou subcordada

.Vernonia onopordioides

265'. Folhas evidentemente pilosas

275. Plantas aculeadas

276. Folhas elíticas; acúleos com a base inflada

Solanum lycocarpum

276'. Folhas deltóides; acúleos com a base não inflada.

Solanum palinacanthum

275'. Plantas inermes

277. Base foliar com glândulas estipitadas (Figura 3.17)

Croton sclerocalyx

277'. Base foliar sem glândulas

278. Presença de estípulas (olhar folhas jovens)

279. Folhas sagitadas; caule anguloso Byttneria sagittifolia

279'. Folhas não sagitadas; caule não anguloso

280. Margem foliar recortada na metade superior

281. Folhas circulares, ápice emarginado Sida glaziovii

281'. Folhas oblongas, ápice apiculado Sida rhombifolia

280'. Margem foliar toda recortada

282. Plantas com pilosidade amarelo-avermelhada (olhar ápice dos ramos 
jovens); folhas com base assimétrica

Helicteres sacarolha

282'. Plantas com pilosidade de outra cor; folhas com base simétrica

283. Folhas com base cordada

284. Margem do limbo foliar denteada, pecíolo maior que $2 \mathrm{~cm}$ compr.

284'. Margem do limbo foliar serreada, pecíolo até $1 \mathrm{~cm}$ compr.

285. Pulvino presente

285'. Pulvino ausente.

Pavonia hexaphylla

'. Folhas com base atenuada, obtusa ou subcordada

286. Ramos jovens com pêlos glandulares; folhas cartáceas, tomentosas, base atenuada.

Piriqueta rosea

286'. Ramos jovens sem pêlos glandulares; folhas membranáceas,

velutinas ou híspidas, base obtusa ou subcordada

287. Folhas elíticas ou obovais, velutinas, com até $3 \mathrm{~cm}$ compr., base arredondada

Waltheria americana

287 '. Folhas ovais ou lanceoladas, híspidas, com mais de $5 \mathrm{~cm}$ compr., base cordada

288. Folhas ovais, margem com recorte irregular

Waltheria communis

288'. Folhas lanceoladas, margem com recorte regular.

278'. Ausência de estípulas

289. Caule alado Peltaea edouardii

289'. Caule não alado

290. Pecíolo longo (maior que $1 \mathrm{~cm}$ compr.)

291. Folhas elíticas, não escabras na face superior, nervuras imersas

292. Ramos e folhas pilosos.

Trichogonia salviifolia

292'. Ramos e folhas glabros

Porophyllum ruderale

291'. Folhas ovais, escabras na face superior, nervuras salientes na face inferior

293. Plantas eretas

Davilla elliptica

293'. Plantas volúveis

Davilla rugosa

290'. Pecíolo curto (menor que $0,5 \mathrm{~cm}$ compr.)

294. Folhas discolores

295. Folhas elíticas, escabras na face na face superior.

Cordia corymbosa

295'. Folhas obovais ou lanceoladas, não escabras na face superior

296. Folhas obovais, margem crenada, ápice obtuso

Vernonia herbacea

296'. Folhas lanceoladas, margem serreada, ápice agudo Vernonia holosericea

294'. Folhas concolores

297. Ramos e folhas jovens lanuginosos

Vernonia bardanoides

297'. Ramos e folhas jovens não lanuginosos

298. Folha ovada, base subcordada

Vernonia lappoides

298'. Folha obovada ou elítica, base não subcordada

299. Folha séssil

300. Folhas híspidas, margem serreada, nervuras secundárias inconspícuas.....

Conyza canadensis

300'. Folhas tomentosas, margem crenada, nervuras secundárias evidentes Elephantopus biflora

299'. Folha curto-peciolada

301. Folhas coriáceas, obovais

Vernonia scabra

301'. Folhas membranáceas, elíticas Trichogonia salviifolia

258'. Margem íntegra

302. Caule alado

Pterocaulon rugosum

302'. Caule não alado

303. Hábito prostrado, volúvel ou planta trepadeira

304. Folhas acródromas (3- a 7-nervadas)

Smilax cissoides

304'. Folhas não acródromas

305. Plantas volúveis

306. Estípulas foliáceas presentes

Aristolochia giberti

306'. Estípulas ausentes.

305'. Plantas prostradas

307. Estípulas presentes; folhas cartáceas, pilosas

Galactia decumbens 
307'. Estípulas ausentes; folhas membranáceas, glabras

Ipomoea procurrens 303'. Hábito ereto ou decumbente

308. Folhas hifódromas

309. Planta subáfila

Crumenaria polygaloides

309'. Planta multifoliada

310. Folhas carnosas

311. Plantas hirsutas, folhas oblanceoladas

Portulaca hirsutissima

311'. Plantas glabras, folhas elíticas Portulaca mucronata

310'. Folhas não carnosas

312. Folhas obovais

Baccharis humilis

312'. Folhas lineares

313. Folhas com mais de $2 \mathrm{~mm}$ larg

313'. Folhas com até $1 \mathrm{~mm}$ larg.

314. Ramos com estrias

Baccharis rufescens

314'. Ramos sem estrias

Porophyllum angustissimum

08'. Folhas com outros tipo de nervação

315. Folhas glabras ou glabrescentes

316. Plantas latescentes

317. Planta sem caule aparente à superfície; folhas congestas no ápice dos ramos, sem glândulas.

317'. Planta com caule aparente à superfície; folhas laxas, com duas glândulas na base do limbo (Figura 3.16) Sapium glandulatum

316'. Plantas não latescentes

318. Folhas com estípulas

319. Folhas sagitadas; caule anguloso

Byttneria sagittifolia

319'. Folhas não sagitadas; caule não anguloso Sida linifolia

318'. Folhas sem estípulas

320. Folhas circulares, até $1 \mathrm{~cm}$ compr.

Phyllanthus orbiculatus

320 '. Folhas não circulares, mais de $2 \mathrm{~cm}$ compr.

321. Plantas sobolíferas

322. Limbo foliar menor que $3 \mathrm{~cm}$ compr. e $0,5 \mathrm{~cm}$ larg., ápice agudo

Baccharis humilis

322'. Limbo foliar maior que $10 \mathrm{~cm}$ compr. e $4 \mathrm{~cm}$ larg., ápice arredondadoAnacardium humile 321'. Plantas subarbustivas

323. Folhas cartáceas, ovais

Vernonia onopordioides

323'. Folhas coriáceas, largo-ovais ou elíticas

324. Folhas largo-ovais, base cordada, domáceas saculiformes na axila

das nervuras na face inferior.

Anonna coriacea

324'. Folhas elíticas, base atenuada, sem domáceas................................Vernonia obtusata

$315^{\prime}$. Folhas pilosas ou com indumento de escamas

325. Plantas armadas

326. Dois espinhos na axila das folhas.

Dasyphyllum sprengelianum

326'. Vários acúleos em toda a planta Solanum lycocarpum

325'. Plantas inermes

327. Hábito escandente

Securidaca tomentosa

327'. Hábito ereto ou decumbente

328. Estípulas desenvolvidas

329. Estípulas foliáceas

Solanum erianthum

329'. Estípulas lineares ou triangulares

330. Folhas membranáceas, linear-lanceoladas; estípulas lineares

Sida linifolia

330'. Folhas coriáceas, ovais, elíticas ou obovais; estípulas triangulares .Licania humilis

328'. Estípulas nulas ou inconspícuas

331. Folhas actinódromas, 5- a 7-nervadas

Cissampelos ovalifolia

331 '. Sem esta característica

332. Pecíolo longo (maior que $1 \mathrm{~cm}$ compr.)

333. Planta sobolífera, latescente; folhas oblanceoladas, pilosidade ferrugínea Pouteria subcaerulea

333'. Planta herbácea ou subarbustiva, não latescente; folhas ovais ou elíticas, pilosidade esbranquiçada

334. Folhas discolores 
335. Folhas elíticas, nervuras impressas na face superior, ápice e base agudos, pilosidade esbranquiçada Gochnatia pulchra

335'. Folhas oblongas, nervuras imersas na face superior, ápice e base obtusos, pilosidade ferrugínea

Vernonia ferruginea

334'. Folhas concolores

336. Nervuras salientes na face superior, margem ondulada

Eremanthus sphaerocephalus

336'. Nervuras imersas na face superior, margem plana

337. Folhas elíticas, seríceas, base aguda.............................. Vernonia polyanthes

337'. Folhas ovais, tomentosas, base cordada ............................ Gochnatia barrosii

332'. Pecíolo curto (até $0,5 \mathrm{~cm}$ compr.)

338. Indumentos de pêlos estrelados ou lepidoto (escamas)

339. Indumento lepidoto

Duguetia furfuracea

339'. Indumento de pêlos estrelados (Figura 3.18)

340. Ramos tomentosos; folhas lanceoladas. Croton eriocladus

340'. Ramos híspidos; folhas obovais Croton pohlianus

338'. Indumentos de pêlos simples ou compostos, não estrelados

341. Limbo foliar discolor

342. Folhas pilosas em ambas as faces

343. Caule tomentoso; folhas linear-lanceoladas Achyrocline satureoides

343'. Caule híspido; folhas obovais Vernonia herbacea

342 '. Folhas glabras ou glabrescente na face superior

344. Plantas sobolíferas; folhas oblongas ..... Parinari excelsa

344'. Plantas herbáceas ou subarbustivas; folhas elíticas ou lanceoladas

345. Folhas impressas na face superior..... Gochnatia pulchra

$345^{\prime}$. Folhas não impressas na face superior

346. Limbo lanceolado, margem revoluta.

Vernonia apiculata

346'. Limbo elítico, margem plana.

Vernonia holosericea

341'. Limbo foliar concolor

347. Folhas pilosas

348. Planta sobolífera, com látex; folhas oblanceoladas, pilosidade ferrugínea.

Pouteria subcaerulea

348'. Planta herbácea, sem látex; folhas lineares-lanceoladas ou obovais, pilosidade amarelada ou glauca

349. Folhas linear-lanceoladas, pilosidade esbranquiçada.....

349'. Folhas obovais, pilosidade glauca

Achyrocline satureoides

347'. Folhas glabras, glabrescente ou escabras na face superior Anonna dioica

350. Ramos jovens e face inferior das folhas lanuginosas. Vernonia bardanoides 350'. Ramos jovens e face inferior das folhas não lanuginosas

351. Folhas elíticas

Vernonia holosericea

351 '. Folhas ovais Vernonia lappoides

257'. Filotaxia oposta ou verticilada

352. Folhas verticiladas

353. Plantas com látex

Ditassa acerosa

353'. Plantas sem látex

354. Margem serreada ou denteada.

354'. Margem íntegra

355. Limbo foliar com pontuações translúcidas (olhar contra a luz)

356. Margem foliar amarelada; folhas largo-ovais Eugenia livida

356'. Margem foliar indiferenciada; folhas oblongas, elíticas ou cordadas

357. Folhas oblongas ou elíticas, pilosas (pilosidade ferrugínea facilmente removível na face inferior do limbo), base cuneada

357 '. Folhas ovais, glabras ou glabrescentes, base cordada Myrcia lingua

355'. Limbo foliar sem pontuações translúcidas

358. Estípulas interpeciolares presentes

359. Estípula fimbriada; folhas lineares. Borreria verticilata

359'. Estípula íntegra, com um ápice; folhas elíticas. Declieuxia fruticosa

358'. Estípulas interpeciolares ausentes 
360. Limbo foliar com glândulas na face inferior. Banisteriopsis campestris 360'. Limbo foliar sem glândulas

361. Folhas lineares, com estípulas Polycarpea corymbosa

361 '. Folhas oblongas ou lanceoladas, sem estípulas Kanimia oblongifolia

352'. Folhas opostas

362. Folhas pinatífidas. Bidens gardneri

362'. Folhas inteiras ou lobadas

363. Plantas hemiparasitas. Psittacanthus robustus

363'. Plantas autotróficas

364. Hábito volúvel

365. Planta latescente, com látex leitoso

366. Folhas lineares

366'. Folhas elíticas, oblongas ou ovais

367. Limbo foliar com glândula na face superior

367'. Limbo foliar sem glândulas

368. Folhas glabras.

368'. Folhas pilosas

369. Pecíolo maior que $1 \mathrm{~cm}$ compr., base foliar cordada....... Oxypetalum appendiculatum 369 '. Pecíolo menor que $0,5 \mathrm{~cm}$ compr., base foliar obtusa ou subcordada

370. Limbo foliar menor que $1 \mathrm{~cm}$ compr., ápice obtuso ou arredondado ... Ditassa nitida 370'. Limbo foliar maior que 5cm compr., ápice agudo

371. Ramos glabrescentes; folhas oblongas Odontadenia lutea

371'. Ramos pubescentes; folhas ovais Temnadenia violacea

365 '. Planta não latescente ou látex aquoso

372. Folhas eglandulosas

373. Folhas com pilosidade ferrugínea, nervação acródroma Strychnos bicolor

373'. Folhas com pilosidade esbranquiçada ou glabras, nervação actinódroma ou eucamptódroma

374. Folhas ovais, actinódromas, base cordada, margem denteada . Mikania cordifolia

374'. Folhas oblongas ou elíticas, eucamptódroma, base atenuada, margem íntegra.... Banisteriopsis pubipetala

372 '. Folhas glandulosas na face inferior

375. Folhas glabras

376. Folhas lanceoladas, glândulas supra-basais Banisteriopsis stellaris

376'. Folhas ovais, glândulas basais Heteropteris umbellata

375'. Folhas pilosas

377. Presença de estípulas interpeciolares (olhar folhas jovens) Peixotoa tomentosa

377'. Ausência de estípulas interpeciolares

378. Folhas discolores

379. Folhas buladas, ápice obtuso

Banisteriopsis argyrophylla

379'. Folhas não buladas, ápice agudo Banisteriopsis laevifolia

378'. Folhas concolores

380. Glândulas na base do limbo foliar

Banisteriopsis variabilis 380'. Glândulas acima da base do limbo foliar Mascagnia cordifolia

364'. Hábito ereto ou prostrado

381. Plantas latescentes

382. Folhas lineares, com até $1 \mathrm{~cm}$ compr.

Ditassa acerosa

382 '. Folhas oblongo, oboval ou orbicular, com mais de $5 \mathrm{~cm}$ compr.

383. Folhas oblongas ou obovais

383'. Folhas circulares.

Mandevilla vellutina

381'. Plantas não latescentes

384. Presença de estípulas interpeciolares (olhar folhas jovens)

385. Limbo foliar com duas glândulas na base. Peixotoa tomentosa

385'. Limbo foliar sem glândulas (Rubiaceae)

386. Nervuras impressas na face superior

387. Estípulas não fimbriadas; limbo foliar discolor

Sabicea brasiliensis

387'. Estípulas fimbriadas ou apenas o ápice fimbriado; limbo foliar concolor

388. Folhas elíticas, craspedódromas.

Diodia schumannii

388'. Folhas lanceoladas ou lineares, hifódromas 
389. Folhas lanceoladas, margem plana

Diodia teres

389'. Folhas lineares, margem revoluta

Borreria verticilata

386'. Nervuras não impressas

390. Estípula íntegra, com um ápice

391. Folhas pubescentes, arroxeadas na face inferior.

Coccocypselum lanceolatum

391'. Folhas glabrescentes, esverdeadas na face inferior

392. Estípula com o ápice linear; folhas com até $5 \mathrm{~cm}$ compr. ....... Declieuxia fruticosa

392'. Estípula com o ápice obtuso ou apiculado; folhas com mais de

$10 \mathrm{~cm}$ compr.

Alibertia sessilis

390'. Estípula fimbriada ou com dois ápices

393. Folhas craspedódromas; estípulas fimbriadas

393'. Folhas com outros tipos de nervação; estípulas com dois ápices

394. Plantas híspidas

Borreria warmingii

394'. Plantas glabras

395. Folhas rígido-coriáceas

396. Ápice agudo, base obtusa; limbo foliar com até $10 \mathrm{~cm}$ compr. e

$5 \mathrm{~cm}$ larg.

Palicourea coriacea

396'. Ápice obtuso, base atenuada; limbo foliar com mais de $15 \mathrm{~cm}$

compr. e $10 \mathrm{~cm}$ larg.

..Palicourea rigida

395'. Folhas membranáceas ou cartáceas

397. Nervação eucamptódroma .

Psychotria deflexa

397'. Nervação broquidódroma

398. Limbo foliar estreito-elítico, ápice agudo

Psychotria capitata

398'. Limbo foliar elítico, ápice acuminado

Psychotria barbiflora

384'. Ausência de estípulas interpeciolares

399. Limbo foliar com pontuações translúcidas (olhar contra a luz)

400. Margem foliar amarelada

401. Folhas elíticas, base obtusa

Eugenia bimarginata

401'. Folhas largo-ovais, base subcordada Eugenia livida

400'. Margem foliar indistinta

402. Ramos jovens quadrangulares; folhas densamente tomentosas na face

inferior, pilosidade esbranquiçada

..Psidium cinereum

402'. Ramos jovens circulares; folhas glabras ou glabrescentes, se

tomentosas, com pilosidade ferrugínea

403. Folhas densamente tomentosas quando jovens (pilosidade ferrugínea,

facilmente removível).

Myrcia lingua

403'. Folhas glabras ou glabrescentes

404. Folhas oblanceoladas, nervuras imersas na face inferior da folha

..Psidium australe

404'. Folhas largo-elíticas ou elíticas, nervuras salientes na face inferior da folha

Campomanesia pubescens

399'. Limbo foliar sem pontuações translúcidas

405. Ramos jovens quadrangulares

406. Folhas acródromas, clatradas

Miconia stenostachya

406'. Folhas com outros tipos de nervação, não clatradas

407. Caule com estrias nos ângulos

408. Folhas subsésseis (pecíolo menor que $0,5 \mathrm{~cm}$ compr.), tomentosas, margem serreada

Hyptis brevipes

408'. Folhas pecioladas (pecíolo maior que $1 \mathrm{~cm}$ compr.), híspidas, margem duplo-serreada

407'. Caule sem estrias nos ângulos

409. Base foliar cuneada

410. Margem foliar serreada ou denteada

411. Folhas estreito-elíticas, margem serreada

Hyptis rugosa

411'. Folhas ovais ou elíticas, margem crenada

Hyptis mutabilis

410'. Margem foliar crenada

412. Gemas e folhas jovens densamente piloso-esbranquiçados

412'. Gemas e folhas jovens não densamente piloso-esbranquiçados

Peltodon tomentosus

Lantana fucata 
409'. Base foliar aguda, obtusa ou cordada

413. Lâmina foliar escabra na face superior.

Lantana camara

413'. Lâmina foliar não escabra

414. Margem foliar íntegra Ruellia geminiflora

414'. Margem foliar crenulada, serreada ou serrilhada

415. Margem foliar crenulada. Lippia salviifolia

415'. Margem foliar serreada ou serrilhada

416. Folhas buladas, velutinas; ramos glabrescentes

Lippia lupulina

416'. Folhas não buladas, tomentosas ou glabrescentes; ramos

híspidos.

Hyptis eryophylla

405'. Ramos jovens circulares, às vezes sulcados

417. Folhas acródromas ou actinódromas

418. Nervação clatrada

419. Folhas concolores, buladas, com pilosidade amarelada......

Leandra lacunosa

419'. Folhas discolores, não buladas, com pilosidade esbranquiçada

420. Folhas sésseis, folhas jovens glabras.....

420'. Folhas pecioladas, folhas jovens pilosas (pilosidade ferrugínea,

facilmente removível)

Miconia fallax

Nervação não clatrada

421. Margem foliar íntegra

422. Folhas escabras

423. Folhas lineares.

Buchnera lavandulacea

423'. Folhas ovais ou elíticas Viguiera discolor

422'. Folhas não escabras

424. Plantas subarbustivas; folhas glabras

Arrabidea brachypoda

424'. Plantas herbáceas; folhas pilosas

425. Folhas peicoladas, folhas senescentes persistentes.....Eupatorium squalidum

425'. Folhas sésseis, folhas senescentes caducas. Gomphrena virgata

421'. Margem foliar recortada

426. Folhas ovais, ápice acuminado

427. Ramos sulcados, glabros.

Wulffia stenoglossa

427'. Ramos não sulcados, tomentosos quando jovens ...Eupatorium maximiliani 426'. Sem o conjunto de caracteres

428. Base foliar amplexicaule; plantas híspidas.

Aspilia reflexa

428'. Base foliar não amplexicaule; plantas tomentosas ou hispídulas

429. Folhas impressas na face superior.....

Lippia lupulina

429'. Folhas não impressas na face superior

430. Folhas híspidas, margem crenada

430'. Folhas pubérulas, margem serreada .

Eupatorium chlorolepsis

417'. Folhas com outros tipos de nervação

431. Limbo foliar com glândulas na face inferior

432. Folhas discolores, seríceo-esbranquiçadas na face inferior

Banisteriopsis laevifolia

432'. Folhas concolores, não seríceo-esbranquiçadas na face inferior

433. Limbo foliar bulado, ápice mucronado Banisteriopsis campestris

433'. Limbo foliar não bulado, ápice obtuso ou agudo Banisteriopsis variabilis

431'. Limbo foliar sem glândulas

434. Margem foliar recortada

435. Base foliar aguda ou decorrente

436. Folhas elíticas, base aguda. Peritassa campestris

436'. Folhas ovais, base decurrente

435'. Base foliar obtusa ou cordada

437. Base foliar cordada, margem serreada

437'. Base foliar obtusa, margem crenada

438. Folhas buladas, oblongas, elíticas ou ovais, pilosas em ambas as faces.

438'. Folhas não buladas, largo-elíticas, pilosas apenas na face inferior Lippia salviifolia

434'. Margem foliar íntegra Hyptis cana 
439. Presença de estípula intrapeciolar (Figura 3.7).... Byrsonima intermedia

439'. Ausência de estípula intrapeciolar

440. Folhas híspidas

Cuphea carthagenensis

440 '. Folhas glabrescentes, tomentosas ou seríceas

441. Folhas glabrescentes ou tomentosas

442. Folhas glabrescentes, base aguda.....

Hygrophila brasiliensis

442'. Folhas tomentosas na face inferior, base obtusa

Heteropteris byrsonimifolia

441'. Folhas densamente seríceas nas duas faces quando jovens

443. Plantas amareladas, até $20 \mathrm{~cm}$ alt.

Pfaffia jubata

443'. Plantas esbranquiçadas, com mais de $30 \mathrm{~cm}$ alt

444. Folhas elíticas.

Alternanthera brasiliana

444'. Folhas lanceoladas Froelichia lanata

\section{- campo úmido}

1. Arbustos, árvores ou fetos arborescentes (fanerófitas)

2. Samambaias (Pteridophyta)

Cyathea delgadii

2'. Angiospermas (Magnoliophyta)

3. Folhas compostas

4. Plantas aculeadas; folhas digitadas

Rubus brasiliensis

4'. Plantas inermes; folhas bipinadas Jacaranda caroba

3'. Folhas simples

5. Folhas alternas

6. Folhas palmatilobadas

6'. Folhas não palmatilobadas

7. Plantas armadas; pecíolo alado

7'. Plantas inermes; pecíolo não alado

8. Folhas buladas, base assimétrica.

8 '. Folhas não buladas, base simétrica

9. Folhas largo-ovais, base cordada, limbo maior que $10 \mathrm{~cm}$ compr., pêlos estrelados

9'. Folhas elíticas ou lanceoladas, base aguda, limbo menor que $5 \mathrm{~cm}$ compr., pêlos simples

10. Folhas e ramos jovens glabros ..........................................................................................

10'. Folhas e ramos jovens seríceos.......................................................................................... Ludwigia sericea

5'. Folhas opostas

11. Estípulas interpeciolares presentes; nervação broquidódroma.

Tocoyena formosa

11'. Estípulas interpeciolares ausentes; nervação acródroma

12. Folhas glabras

Miconia chamissois

12'. Folhas pilosas

13. Folhas buladas na face superior, base cordada.....

Leandra lacunosa

13'. Folhas não buladas, base atenuada ou arredondada

14. Folhas ovais, base atenuada, pilosas em ambas as faces

Tibouchina stenocarpa

14'. Folhas lanceoladas, base arredondada, glabras na face superior

Tibouchina chamissoana

1'. Ervas ou subarbustos (caméfitas, hemicriptófitas, lianas ou terófitas)

15. Samambaias (Pteridophyta)

16. Lâminas com ramificação dicotômica.

16'. Lâminas sem ramificação dicotômica

17. Lâminas pinadas ou bipinadas (recorte da folha completo)

18. Folhas bipinadas Adiantopsis chlorophylla

18'. Folhas pinadas

19. Folíolos opostos ou subospostos.

Anemia phyllitidis

19'. Folíolos alternos

Thelypteris salzmanii

17'. Lâminas pinatífidas, pinatissectas, bipinatissectas ou tripinatissectas (recorte da folha incompleto)

20. Lâminas tripinatissectas, maiores que $1 \mathrm{~m}$ compr.

Pteridium aquilinum

20'. Lâminas pinatífidas, pinatissectas ou bipinatissectas, menores que $0,8 \mathrm{~m}$ compr. 
21. Lâminas bipinatissectas, pilosas.

Anemia ferruginea

21'. Lâminas pinatífidas ou pinatissectas, glabras

22. Lâminas pinatífidas, margem íntegra.

Thelypteris quadrangularis

22'. Lâminas pinatissectas, margem erosa. Blechnum brasiliense

15'. Angiospermas (Magnoliophyta)

23. Plantas com folhas reduzidas às bainhas

Eleocharis grandis

23'. Plantas foliosas

24. Folhas com lígula e/ou região do colar (Poaceae) (Figura 3.8)

25. Folhas lanceoladas

26. Pêlos glandulosos presentes

Melinis minutiflora

26'. Pêlos glandulosos ausentes

27. Margem da lâmina foliar amarelada

Echinolaena inflexa

27'. Margem da lâmina foliar indiferenciada

28. Plantas decumbentes; lâmina foliar maior que $10 \mathrm{~cm}$ compr.

Brachiaria decumbens

28 '. Plantas eretas; lâmina foliar menor que $5 \mathrm{~cm}$ compr.

Panicum parvifolium

25'. Folhas lineares ou linear-lanceoladas

29. Plantas pilosas

30. Plantas com pêlos glandulosos

Melinis minutiflora

30'. Plantas sem pêlos glandulosos

31. Planta robusta; colmo com $0,5-1 \mathrm{~cm}$ diâm. basal; nós, bainha e face dorsal da lâmina foliar

densamente pilosos; brotamento achatado, amarelo....

Axonopus barbigerus

31'. Sem o conjunto de caracteres

32. Nós pilosos

33. Plantas eretas; brotamento achatado, amarelado

Axonopus marginatus

33'. Plantas procumbentes; brotamento cilíndrico, esverdeado Rhynchelytrum repens

32'. Nós glabros

34. Plantas procubentes

Rhynchelytrum repens

34'. Plantas eretas Panicum cayennensis

29'. Plantas glabras ou com pêlos somente nos nós

35. Lígula pilosa (Figura 3.10) ou nula

36. Região do colar enegrescida.

Aristida jubata

36'. Região do colar não enegrescida

37. Folhas revolutas

Sporolobus indicus

37'. Folhas planas

38. Colmo com até $1 \mathrm{~cm}$ diâm.; lâmina com até $0,8 \mathrm{~m}$ compr., nervura central imersa

38'. Colmo com mais de $2 \mathrm{~cm}$ diâm.; lâmina com mais de $1 \mathrm{~m}$ compr., nervura central

Panicum olyroides

saliente na face inferior

Cortaderia selloana

35'. Lígula membranosa (Figura 3.9)

39. Plantas com coloração avermelhada (olhar nós, folhas jovens, região do colar, lígula)

40. Folhas usualmente revolutas, lâmina foliar com até $3 \mathrm{~mm}$ larg.

Andropogon leucostachys

40'. Folhas planas, lâmina foliar com mais de $5 \mathrm{~mm}$ larg.

41. Margem da lâmina foliar escabra; lígula arredondada

Andropogon bicornis

41'. Margem da lâmina foliar não escabra; lígula acuminada

39'. Plantas sem coloração avermelhada

42. Nós pilosos; lâmina foliar com ápice agudo

Imperata brasiliensis

42'. Nós glabros; lâmina foliar com ápice acuminado

43. Lâmina foliar escabra; lígula com ápice ciliado

Pennisetum setosum

43'. Lâmina foliar não escabra; lígula com ápice íntegro

Digitaria insularis

24'. Folhas sem lígula ou região do colar (outras famílias)

44. Folhas dispostas em rosetas basais

45. Folhas não paralelódromas, sem bainha

46. Folhas discolores

Chaptalia integerrima

46'. Folhas concolores

47. Folhas ovais ou elíticas

Elephantopus mollis

47'. Folhas lanceoladas. Orthopappus angustifolius

45'. Folhas paralelódromas, com bainha

48. Margem foliar espinescente

49. Folhas jovens freqüentemente avermelhadas, lâmina maior que $3 \mathrm{~cm}$ larg., com pêlos lepidotos esbranquiçados 
49. Folhas jovens verdes, lâmina menor que $3 \mathrm{~cm}$ larg., com pêlos lepidotos ferrugíneos

.Ananas ananassoides

48' Margem foliar íntegra, serrilhada ou ciliada

50. Folhas filiformes ou revoluto-cilíndricas

51. Folhas maiores que $40 \mathrm{~cm}$ compr......

51'. Folhas menores que $30 \mathrm{~cm}$ compr.

52 Ápice da bainha piloso..

52'. Ápice da bainha glabro.

Bulbostylis hirtella

50 '. Folhas lineares, lanceoladas ou obovais, planas

53. Margem foliar íntegra ou ciliada, seção do caule circular

54. Folhas membranáceas, margem íntegra

Xyris jupicai

54'. Folhas coriáceas, margem ciliada..... Eryngium junceum

53'. Margem foliar serrilhada, seção do caule triangular

55. Touceiras multiperfilhadas; rizoma com crescimento multidirecional Cyperus diffusus

55'. Touceiras pauciperfilhadas; rizoma com crescimento linear

56. Folhas com mais de $40 \mathrm{~cm}$ compr., margem não escabra.

56'. Folhas com menos de $30 \mathrm{~cm}$ compr., margem escabra .....

Cyperus laetus

Cyperus cayennensis

44'. Folhas dispostas ao longo do caule

57. Folhas com a bainha desenvolvida, sem pecíolo, paralelódromas

58. Caule com seção triangular; folhas linear-lanceoladas, escabras, margem serrilhada

59. Bainha foliar apendiculada; lâmina foliar sem nervuras marginais.

Scleria comosa

59'. Bainha foliar exapendiculada; lâmina foliar com nervuras marginais evidentes

Rhynchospora corymbosa

58'. Caule com seção circular; folhas lanceoladas, não escabras, margem lisa

60. Plantas prostadas; folhas fenestradas

Philodendron eichleri

60'. Plantas eretas; folhas não fenestradas

61. Folhas com bainha aberta

62. Lâminas foliares sésseis, nervuras secundárias ascendentes; lígula presente

62'. Lâminas foliares pecioladas, nervuras secundárias perpendiculares à nervura central; lígula ausente.

...Heliconia hirsuta

61'. Folhas com bainha fechada (Figura 3.19)

63. Folhas espiraladas, lâminas maiores que $15 \mathrm{~cm}$ compr., bainhas glabras

63'. Folhas dísticas, lâminas menores que $10 \mathrm{~cm}$ compr., bainhas pilosas

64. Ramos e folhas jovens hirtelos; folhas elíticas

Costus arabicus

64'. Ramos e folhas jovens glabros; folhas lanceoladas

Commelina erecta

57'. Sem o conjunto de caracteres

65. Folhas compostas ou pinatífidas

66. Filotaxia oposta

67. Plantas trepadeiras; folhas trifolioladas, às vezes um folíolo modificado em gavinha

67. Plantas eretas; folhas bipinadas.

Pyrostegia venusta

66'. Filotaxia alterna

68. Folhas bipinadas

Jacaranda caroba

68 '. Folhas pinadas ou digitadas

69. Folhas multifolioladas

70. Folíolos subopostos ou um folíolo terminal distinto

70'. Folíolos opostos

71. Ramos em ziguezague; estípulas oval-lanceoladas; folíolos assimétricos, nervura central excêntrica.

Chaemaechrista flexuosa

71'. Ramos não em ziguezague; estípulas lineares; folíolos simétricos, nervura central mediana

72. Plantas pilosas (com pêlos glandulosos); folhas sem glândulas.

Chamaechrista cathartica

72'. Plantas glabras; folha com duas glândulas entre as duas primeiras jugas..

Chamaechrista debilis

69'. Folhas 2- a 4- folioladas

73. Folhas paripinadas

74. Folhas unijugas

Zornia latifolia

74'. Folhas bijugas

75. Plantas com pêlos glandulosos; estípulas lineares; folhas com pêlos glandulosos; 
folíolos simétricos.

Chamaechrista campestris

75'. Plantas sem pêlos glandulosos; estípulas cordadas; folhas com glândulas plateliformes; folíolos assimétricos

76. Folíolos largo-obovais, pilosos

Chamaechrista rotundifolia

76'. Folíolos oblanceolados a oblongos, glabros Chamaechrista desvauxii

73'. Folhas trifolioladas

77. Plantas trepadeiras

78. Folíolos linear-lanceolados, margem íntegra, glabros

78'. Folíolos ovais, elíticos ou obovais, margem serreada, pilosos.

Cayaponia espelina

77'. Plantas eretas, prostradas ou volúveis (sem gavinhas)

79. Estípulas soldadas formando pseudo-bainha (Figura 3.15), folíolos com nervura marginal (olhar face inferior)

79'. Sem o conjunto de caracteres

80. Folhas digitadas (folíolos eqüidistantes)

81. Folíolos sem estipelas, glabros

Crotalaria vitellina

81 '. Folíolos com estipelas, pilosos.

Clitoria simplicifolia

80'. Folhas pinadas

82. Folhas com estípulas e estipelas.

Desmodium barbatum

82'. Folhas sem estípulas e estipelas Oxalis physocallyx

$65^{\prime}$. Folhas simples ou unifolioladas

83. Folhas opostas ou verticiladas

84. Folhas verticiladas

85. Folhas lineares, margem íntegra; estípulas presentes; ramos jovens pubérulos, pilosidade esbranquiçada Stylosanthes gracilis

85'. Folhas elíticas, margem denticulada ou serreada; estípulas ausentes; ramos jovens glabros

86. Folhas com mais de $5 \mathrm{~cm}$ compr., margem denticulada .

86'. Folhas com até $3 \mathrm{~cm}$ compr., margem serreada.

Syphocampylus sulfureus

84'. Folhas opostas

87. Folhas pinatífidas.

87'. Folhas inteiras

88. Hábito volúvel

89. Plantas latescentes, com látex leitoso

90. Base foliar glanduloso na face superior. Blepharodon nitidum

90'. Base foliar eglanduloso

91. Plantas tomentosas (pilosidade ferrugínea); folhas largo-ovais

91'. Plantas glabras ou glabrescentes; folhas elíticas ou oblongas

92. Folhas elíticas, base aguda, margem plana .

Prestonia tomenotsa

92'. Folhas oblongas, base arredondada, margem revoluta

Forsteronia glabrescens

89'. Plantas não latescentes ou com látex aquoso

93. Folhas com base cordada, margem denteada, eglandulosa ....

93'. Folhas com base aguda, obtusa ou arredondada, margem íntegra, glandulosa na face inferior

94. Folhas glabras.

94'. Folhas pilosas

95. Folhas discolores; nervuras impressas na face superior.

95'. Folhas concolores; nervuras imersas na face superior

88'. Hábito ereto ou prostrado

96. Ramos jovens quadrangulares

97. Folhas acródromas

98. Plantas hirsutas; folhas com até $3 \mathrm{~cm}$ compr.

98'. Plantas setosas; folhas com mais de $6 \mathrm{~cm}$ compr..... Prestonia coalita

97'. Folhas craspedódromas ou camptódromas

99. Base dos pecíolos fundidas, formando anel amplexicaule (Figura 3.20)

99'. Base dos pecíolos não fundidas

100. Margem foliar denteada

101. Lâmina foliar escabra na face superior, base aguda .

101'. Lâmina foliar não escabra, base cuneada......

100'. Margem foliar crenada

Heteropteris umbellata

Banisteriopsis argyrophylla . Mascagnia cordifolia

Acisanthera alsinaefolia .Tibouchina gracilis

Buddleja brasiliensis 
102. Folhas não buladas, base aguda.

Hyptis marruboides

102'. Folhas buladas, base cuneada

103. Gemas e folhas jovens densamente piloso-esbranquiçados; folhas elíticas, não escabras.

Peltodon tomentosus

103'. Gemas e folhas jovens não densamente piloso-esbranquiçados; folhas ovais; escabras na face superior

Lantana lilacina

96'. Ramos jovens circulares, às vezes sulcados

104. Folhas acródromas

105. Margem foliar íntegra

106. Plantas herbáceas; folhas elíticas, tomentosas, face inferior não amarelada

106'. Plantas subarbustivas; folhas obovais, glabras, face inferior amarelada

Eupatorium squalidum

105. Margem foliar recortada

107. Plantas glabras

108. Margem foliar crenada

108'. Margem foliar serreada

Baccharidastrum triplinervum

107'. Plantas pilosas

109. Folhas elíticas, ápice agudo Eupatorium laevigatum

109'. Folhas ovais, ápice acuminado

110. Ramos sulcados, glabros

Eupatorium squalidum

110'. Ramos não sulcados, tomentosos quando jovens

Wulffia stenoglossa

104'. Folhas craspedódromas, camptódromas ou actinódromas

111. Margem foliar recortada

112. Folhas coriáceas, escabras, ovais

Clibadium armani

112'. Folhas membranáceas, não escabras, elíticas ou oblongas

113. Folhas elíticas, glabrescentes, base cuneada...

Stachytarpheta maximiliani

113'. Folhas oblongas, pubescentes, base arredondada. Sinningia sceptrum

111'. Margem foliar íntegra

114. Presença de estípula intrapeciolar (Figura 3.7)

Byrsonima intermedia

114'. Ausência de estípula intrapeciolar

115. Folhas lanceoladas, maiores que $5 \mathrm{~cm}$ compr., pubérulas, base aguda....... Justicia elegans

$115^{\prime}$. Folhas ovais, menores que $2 \mathrm{~cm}$ compr., glabras, base cordada ........... Cuphea calophylla

83'. Folhas alternas

116. Margem evidentemente recortada

117. Folhas lobadas ou pinatífidas

118. Plantas trepadeiras

Cayaponia espelina

118'. Plantas eretas

119. Plantas aculeadas

Solanum palinacanthum

119'. Plantas inermes Erechtites hieracifolia

117 '. Folhas não lobadas nem pinatífidas

120. Folhas glabras ou glabrescentes

121. Plantas trepadeiras; ramos quadrangulares

Cissus erosa

121'. Plantas não trepadeiras; ramos circulares

122. Folhas amplexicaule, dimorfas (basais lanceoladas, terminais arredondadas).....

122'. Folhas não amplexicaule, isomorfas

123. Plantas com caule suculento; folhas ovais

Emilia coccinea

123'. Plantas sem caule suculento; folhas oblongas, estreito-elíticas ou elíticas

124. Folhas oblongas; plantas sem látex

Begonia cucullata

124 '. Folhas estreito-elíticas ou elíticas; plantas com látex escasso (observar na nervura principal)

125. Folhas estreito-elíticas, maiores que $20 \mathrm{~cm}$ compr.; ramos jovens esverdeados ou amarelados

Lobelia exaltata

$125^{\prime}$. Folhas elíticas, menores que $15 \mathrm{~cm}$ compr.; ramos jovens avermelhados

Vernonia rubriramea

120'. Folhas evidentemente pilosas

126. Plantas aculeadas

127. Folhas elíticas; acúleos com a base inflada

Solanum lycocarpum

127'. Folhas deltóides; acúleos com a base não inflada. Solanum palinacanthum 
126'. Plantas inermes

128. Base foliar com glândulas estipitadas (Figura 3.17)

129. Folhas lanceoladas.

Croton sclerocalyx

129'. Folhas ovais Croton glandulosus

128'. Base foliar sem glândulas

130. Presença de estípulas (olhar folhas jovens)

131. Margem foliar recortada na metade superior Sida glaziovii

131'. Margem foliar toda recortada

132. Margem foliar denteada; pecíolo maior que $5 \mathrm{~cm}$ compr.

132'. Margem foliar serreada; pecíolo menor que $3 \mathrm{~cm}$ compr.

133. Folhas híspidas, nervuras secundárias indo até próximo à margem da folha; estípulas lanceoladas.

...Melochia spicata

133'. Folhas velutinas, nervuras secundárias indo até a metade da margem

foliar; estípulas lineares.

Waltheria americana

130'. Ausência de estípulas

134. Caule alado.

Pterocaulon virgatum

134'. Caule não alado

135. Folhas discolores

136. Folhas elíticas, escabras na face superior

Cordia corymbosa

136'. Folhas obovais, não escabras na face superior Vernonia herbacea

135'. Folhas concolores

137. Folhas curto-pecioladas

Trichogonia salviifolia

137'. Folhas sésseis

138. Folhas híspidas, margem serreada, nervuras secundárias inconspícuas

138'. Folhas tomentosas, margem crenada, nervuras secundárias evidentes

.Conyza canadensis

Elephantopus biflora

116'. Margem íntegra

139. Caule alado

Pterocaulon virgatum

139'. Caule não alado

140. Folhas hifódromas

141. Plantas hirsutas; folhas carnosas

141'. Plantas glabras; folhas não carnosas

Portulaca hirsutissima

140 '. Folhas com outros tipos de nervação

142. Plantas providas de ócrea (Figura 3.21)

143. Ramos jovens avermelhados; folhas glabrescentes

Polygonum acre

143'. Ramos jovens não avermelhados; folhas seríceas Baccharis humilis

142'. Plantas desprovidas de ócrea

144. Folhas glabras ou glabrescentes

145. Folhas com estípulas

146. Folhas simples, lineares; estipelas ausentes

Sida linifolia

146 '. Folhas reduzidas a um folíolo, ovais; estipelas presentes.

145'. Folhas sem estípulas

147. Limbo circular, até $1 \mathrm{~cm}$ compr.

147 '. Limbo não circular, mais de $2 \mathrm{~cm}$ compr.

148. Plantas com caule suculento; folhas ovais, base cuneada.

148'. Plantas sem caule suculento; folhas elíticas, base aguda

Polygonum acuminatum

144'. Folhas pilosas ou com indumento de escamas

149. Plantas armadas

149'. Plantas inermes

150. Estípulas desenvolvidas

151. Estípulas foliáceas

151 '. Estípulas lineares ou triangulares

152. Folhas simples, lineares; estipelas ausentes

....................... Sida linifolia

152'. Folhas reduzidas a um folíolo, ovais; estipelas presentes ....... Desmodium pachyrrizum

150'. Estípulas nulas ou inconspícuas

153. Folhas actinódromas, 5- a 7-nervadas

Cissampelos ovalifolia

153'.Folhas com outros tipos de nervação

154. Folhas pecioladas (pecíolos maiores que $1 \mathrm{~cm}$ compr.)

155. Folhas discolores, nervuras impressas na face superior.

Gochnatia pulchra 
$155^{\prime}$. Folhas concolores, nervuras imersas na face superior

156. Folhas elíticas, seríceas, base aguda..... Vernonia polyanthes

156 '. Folhas ovais, tomentosas, base cordada Gochnatia barrosii

154 '. Folhas sésseis ou subsésseis (pecíolos menores que $0,5 \mathrm{~cm}$ compr.)

157. Indumentos de pêlos estrelados

Croton eriocladus

157'. Indumentos de pêlos simples ou compostos, não estrelados

158. Folhas pilosas em ambas as faces

159. Caule tomentoso; folhas linear-lanceoladas.

Achyrocline satureoides

159'. Caule híspido; folhas obovais Vernonia herbacea

158 '. Folhas glabras ou glabrescente na face superior

160. Folhas discolores

161. Folhas elíticas, impressas na face superior Gochnatia pulchra

161 '. Folhas ovais, imersas na face superior Vernonia apiculata 160'. Folhas concolores

162. Folhas lineares. Vernonia radula

162'. Folhas ovais ou elíticas

163. Folhas pubérulas (pilosidade esbranquiçada), ápice e base agudos.

Vernonia petiolaris

163'. Folhas híspidas (pilosidade ferrugínea), ápice e base arredondados

Gaylussacia brasiliensis

\section{- mata ciliar}

1. Samambaias (Pteridophyta)

2. Plantas arborescentes, com cerca de $2 \mathrm{~m}$ alt.; lâminas bipinatissectas

Cyathea delgadii

2'. Plantas herbáceas, com cerca de $0,5 \mathrm{~m}$ alt.; lâminas pinadas ou pinatissectas

3. Lâminas pinadas.

Thelypteris salzmanii

3'. Lâminas pinatissectas Blechnum brasiliense

1'. Angiospermas (Magnoliophyta)

4. Ervas ou subarbustos (caméfitas, hemicriptófitas ou lianas)

5. Plantas volúveis ou trepadeiras

6. Plantas latescentes.

Forsteronia velloziana

6'. Plantas não latescentes

7. Presença de estípulas interpeciolares (olhar ramos jovens).

Manettia gracilis

7'. Ausência de estípulas

8. Limbo foliar com pontuações translúcidas (olhar contra a luz)

9. Folíolos glabros, ápice acuminado, base atenuada Pyrostegia venusta

9'. Folíolos pilosos, ápice agudo, base obtusa

8'. Limbo foliar sem pontuações translúcidas

10. Folhas elíticas; lenticelas evidentes nos ramos.

Fridericia speciosa

10 '. Folhas ovais; lenticelas inconspícuas nos ramos. Arrabidaea florida

5'. Plantas eretas

11. Folhas paralelódromas, com bainha

Heliconia hirsuta

$11^{\prime}$.Folhas com outros tipos de nervação, sem bainha

12. Folhas alternas Trichogonia salviifolia

12'. Folhas opostas

Palicourea crocea

13. Presença de estípulas interpeciolares (olhar ramos jovens)

Cuphea calophylla

13'. Ausência de estípulas Justicia elegans

14 '. Base foliar aguda ou atenuada, limbo com mais de $5 \mathrm{~cm}$ compr.

4'. Arbustos ou árvores (fanerófitas)

15. Folhas compostas

16. Plantas armadas; folhas bipinadas. Acacia paniculata

16'. Plantas inermes; folhas pinadas

17. Raque foliar alada, com glândulas interjugas (Figura 3.22).

17'. Raque foliar sem alas, sem glândulas

..Inga uruguensis 
18. Folíolos elíticos, odoríferos

Tapirira guianensis

18'. Folíolos oblongos, não odoríferos Andira anthelmia

15'. Folhas simples

19. Folhas verticiladas ou opostas

20. Folhas verticiladas

Vochysia tucanorum

20'. Folhas opostas

21. Plantas sem odor; folhas discolores, com pilosidade esbranquiçada na face inferior

Trigonia nivea

21'. Plantas com odor desagradável; folhas concolores, glabras ou com pilosidade ferrugínea

22. Folhas pilosas (pilosidade ferrugínea), base cordada, margem erosa

Siparuna apiosyce

22 '. Folhas glabras, base atenuada, margem íntegra Siparuna guianensis

19'. Folhas alternas

23. Folhas palmatilobadas

Cecropia pachystachya

23'. Folhas não palmatilobadas

24. Folhas buladas, base assimétrica.

24'. Folhas não buladas, base simétrica

25. Folhas com pilosidade esbranquiçada na face inferior, base cordada

Piper gaudichaudianum

25 '. Folhas com pilosidade ferrugínea, base aguda, cuneada, obtusa ou arredondada

26. Folhas obovais, base aguda ou cuneada, sem glândulas

Croton urucurana

26'. Folhas largo-ovais, base obtusa ou arredondada, com duas glândulas na base do limbo

Hyeronima alchorneoides

\section{- floresta estacional semidecídua}

1. Ervas ou subarbustos (caméfitas, epífitas, hemicriptófitas, lianas ou fanerófitas com até $0,5 \mathrm{~m}$ alt.)

2. Samambaias (Pteridophyta)

3. Lâminas simples

Microgramma squamulosa

3'. Lâminas pinatissectas Pleopeltis angusta

2'. Angiospermas (Magnoliophyta)

4. Folhas com lígula e região do colar (Figura 3.8)

Olyra micrantha

4'. Folhas sem lígula e região do colar

5. Folhas dispostas em rosetas basais

6. Folhas craspedódromas, sem bainha

Elephantopus mollis

6'. Folhas paralelódromas, com bainha

7. Plantas epífitas; folhas lineares a linear-lanceoladas

8. Plantas paucifoliadas; folhas lineares, lâmina com mais de $1 \mathrm{~m}$ compr., margem espinescenteAcanthostachys strobilac

8'. Plantas multifoliadas; folhas linear-lanceoladas, lâmina com até $20 \mathrm{~cm}$ compr., margem íntegra. Tillandsia geminiflora

7'. Plantas terrestres; folhas obovais, oblongas ou largo-ovais

9. Folhas sésseis, obovais

Mesadenella cuspidata

9'. Folhas pecioladas, oblongas ou largo-ovais

10. Lâmina foliar com listras esbranquiçadas na face superior

Calathea zebrina

10'. Lâmina foliar sem listras

Calathea sellowii

5'. Folhas dispostas ao longo do caule

11. Folhas compostas ou pinatífidas

12. Filotaxia oposta

13. Gavinha indivisa

14. Folíolos pilosos.

Cremastus pulcher

14'. Folíolos glabros Arrabidaea pulchella

13'. Gavinha trífida

15. Folíolos com pontuações translúcidas, base dos folíolos arredondada

Pyrostegia venusta

15'. Folíolos sem pontuações translúcidas, base dos folíolos aguda. Arrabidaea florida

12'. Filotaxia alterna

16. Folhas bipinadas

17. Folíolos com duas nervuras basais, formando pseudo-pecíolo

17'. Folíolos sem duas nervuras basais

Serjania reticulata

16'. Folhas pinadas ou digitadas Cardiospermum grandiflorum 
18. Folhas pinadas, 3 -folioladas

Macroptilium gracile

18'. Folhas digitadas, 5-(7-)folioladas Ipomoea cairica

$11^{\prime}$. Folhas simples

19. Filotaxia alterna

20. Margem recortada

21. Base foliar aguda, margem crenada

Helicteres brevispira

21'. Base foliar cordada, margem serreada Pavonia hexaphylla

20'. Margem íntegra

22. Plantas eretas

23. Folhas glabras, base aguda

Actinostemon communis

23 '. Folhas pilosas, base cordada ou cuneada

24. Estípulas presentes (olhar folhas jovens); folhas ovais, base cordada

24'. Estípulas ausentes; folhas elíticas ou obovais, base cuneada....

Wissadula subpeltata

22'. Plantas volúveis

25. Folhas acródromas (3- a 7-nervadas)

26. Plantas inermes; folhas cartáceas .

26'. Plantas armadas; folhas coriáceas.....

Dioscorea amaranthoides

$25^{\prime}$. Folhas com outros tipos de nervação

27. Estípulas foliáceas presentes; folhas ovais, pecíolo inserido na base .

27'. Estípulas foliáceas ausentes; folhas circulares, peltadas.....

... Smilax cissoides

19'. Filotaxia oposta

28. Plantas volúveis

29. Plantas latescentes

30. Folhas glabras, margem revoluta

Mesechites mansoana

30'. Folhas pilosas, margem plana

Temnadenia violacea

29'. Plantas não latescentes

31. Folhas acródromas, com pilosidade ferrugínea.

Strychnos bicolor

31'. Folhas com outros tipos de nervação, glabras ou com pilosidade argêntea

32. Folhas concolores, glabras, nervuras imersas na face superior.

Tetrapteris guilleminiana

32'. Folhas discolores, com pilosidade argêntea, nervuras impressas na face superior

Banisteriopsis argyrophylla

28'. Plantas eretas

33. Estípulas interpeciolares ausentes

34. Folhas pilosas, ovais ou largo-ovais, actinódromas, base atenuada

Eupatorium maximiliani

34'. Folhas glabras, elíticas ou obovais, eucamptódromas, base obtusa Hybanthus atropurpureus

33'. Estípulas interpeciolares presentes

35. Plantas híspidas

Psychotria tricholoba

35. Plantas glabras

36. Estípulas persistentes; folhas com mais de $10 \mathrm{~cm}$ compr. e $4 \mathrm{~cm}$ larg.

Palicourea crocea

36 '. Estípulas caducas; folhas com até $6 \mathrm{~cm}$ compr. e $3 \mathrm{~cm}$ larg.

37. Folhas estreito-elíticas, ápice agudo

37'. Folhas elíticas, ápice acuminado

Psychotria capitata

1'. Arbustos ou árvores (fanerófitas)

38. Folhas compostas

39. Folhas digitadas

40. Folhas e ramos jovens glabros, folíolos não bulados.

40 '. Folhas e ramos jovens tomentosos (com pêlos estrelados), folíolos bulados na face superior

Tabebuia serratifolia

Zeyhera tuberculosa

39'. Folhas bipinadas, pinadas ou ternadas

41. Folhas bipinadas

42. Plantas armadas

42'. Plantas inermes

43. Folíolos com mais de $5 \mathrm{~mm}$ compr.

Acacia polyphylla

43 '. Folíolos com até $2 \mathrm{~mm}$ compr.

Anadenanthera falcata

41 '. Folhas pinadas ou ternadas

44. Folhas com 2 (aparentemente 1, em Bauhinia) a 3 folíolos

45. Folhas bifolioladas

46. Folíolos soldados entre si, simulando folhas simples

Bauhinia forficata

46'. Folíolos livres entre si Hymenaea courbaril

$45^{\prime}$. Folhas trifolioladas 
47. Filotaxia oposta ou suboposta; folíolos elíticos, base aguda. Esenbeckia febrifuga

47'. Filotaxia alterna; folíolos largo-trulados, base arredondada Platyciamus regnellii

44'. Plantas com 5 ou mais folíolos

48. Raque foliar terminando em pequeno apêndice (Figura 3.2)

49. Folhas com mais de 13 folíolos; raque foliar canaliculada.

Platypodium elegans

49'. Folhas com 6 a 9 folíolos; raque foliar cilíndrica

50. Folíolos com margem recortada

51. Folíolos oblongos, denteados, pilosos na face inferior quando adultos.

51'. Folíolos obovais, pouco denteados (dentes esparsos na metade superior), glabros

Cupania vernalis

0'. Folíolos com margem íntegra

52. Folíolos com mais de $15 \mathrm{~cm}$ compr. e $7 \mathrm{~cm}$ larg., nervuras terciárias imersas

Cupania oblongifolia

52 '. Folíolos com até $10 \mathrm{~cm}$ compr. e $4 \mathrm{~cm}$ larg., nervuras terciárias salientes

53. Raque foliolar e nervura central dos folíolos pilosas

Cupania oblongifolia

53'. Raque foliolar e folíolos glabros

Magonia pubescens

Matayba elaeagnoides

48'. Sem esse caráter

54. Folhas paripinadas

55. Folhas com 6 a 8 folíolos (raramente 10), folíolos com pontuações translúcidas no limbo

Copaifera langsdorfii

55'. Folhas com mais de 13 folíolos, folíolos sem pontuações translúcidas no limbo ....Platypodium elegans

54'. Folhas imparipinadas

56. Plantas armadas

57. Folíolos com até $2 \mathrm{~cm}$ compr., ápice retuso, limbo sem pontuações translúcidas

Machaerium aculeatum

57'. Folíolos com mais de 5cm compr., ápice agudo ou acuminado, limbo com pontuações translúcidas (olhar contra a luz)

58. Folíolos membranáceos, margem crenada, pilosos (com pêlos estrelados) ....Zanthoxylum rhoifolium

58'. Folíolos coriáceos, margem íntegra, glabros. Zanthoxylum riedelianum

56'. Plantas inermes

59. Folíolos evidentemente pilosos

60. Folíolos elíticos ou obovais.

60 '. Folíolos lanceolados ou ovais

61. Folíolos lanceolados, pubescentes quando jovens, ápice retuso

.Andira cuiabensis

61 '. Folíolos ovais, glabros, ápice agudo

Pterodon pubescens

59'. Folíolos glabros ou glabrescentes

62. Folíolos com margem crenada

62'. Folíolos com margem íntegra

63. Folíolos alternos

64. Folhas com até 9 folíolos; folíolos ovais.

Dalbergia frutescens

64'. Folhas com mais de 9 folíolos; folíolos oblongos.

Machaerium stiptatum

63 '. Folíolos opostos ou subopostos

65. Folíolos com domáceas na face inferior (Figura 3.23)

Cedrela fissilis

65'. Folíolos sem domáceas

66. Folíolos ovais, base cordada ou assimétrica; ramos jovens glabros

Protium heptaphyllum

66'. Folíolos elíticos ou obovais, base atenuada ou cuneada; ramos jovens pubescentes

67. Folíolos elíticos, não odoríferos, ápice agudo, base atenuada

67'. Folíolos obovais, odoríferos, ápice acuminado, base cuneada .....

Trichilia hirta

38'. Folhas simples

68. Folhas verticiladas ou opostas

69. Folhas verticiladas

70. Três folhas por nó; folhas elíticas, ápice agudo; com estípulas interpeciolares Amaioua guianensis

70 '. Quatro folhas por nó; folhas obovais, ápice retuso; sem estípulas interpeciolares Vochysia tucanorum

69'. Folhas opostas

71. Base do pecíolo com glândulas (Figura 3.5)

Qualea grandiflora

71'. Base do pecíolo sem glândulas

72. Presença de estípulas interpeciolares (olhar ramos jovens)

73. Plantas armadas

Randia spinosa

73'. Plantas inermes

74. Folhas pilosas 
75. Folhas ovais, pecíolo maior que $3 \mathrm{~cm}$ compr.

Guettarda viburnoides

75 '. Folhas elíticas ou obovais, pecíolo menor que $2 \mathrm{~cm}$ compr.

76. Folhas buladas; estípulas com dentes subulados (Figura 3.24)

Rudgea viburnoides

76'. Folhas não buladas; estípulas triangulares ..... Amaioua guianensis

74'. Folhas glabras

77. Limbo foliar menor que $8 \mathrm{~cm}$ compr.

Chiococca alba

77 '. Limbo foliar maior que $10 \mathrm{~cm}$ compr.

78. Folhas largo-oblongas, base obtusa; ápice estipular agudo

78'. Folhas elíticas, base aguda ou atenuada; ápice estipular apiculado ou aristado

79. Folhas com nervuras secundárias salientes, margem plana; ápice estipular apiculadoAlibertia macrophylla

79'. Folhas com nervuras secundárias imersas, margem levemente revoluta; ápice estipular aristado

Ixora venulosa

72'. Ausência de estípulas interpeciolares

80. Limbo foliar sem pontuações translúcidas, folhas não odoríferas

81. Folhas escabras na face superior

Aloysia virgata

81 '. Folhas não escabras

82. Folhas glabras

Rhamnidium elaeocarpum

82 '. Folhas pilosas

83. Folhas obovais, pecíolo cilíndrico; gema terminal recoberta por pilosidade esbranquiçada; ramos quadrangulares

83'. Folhas elíticas ou ovais, pecíolo canaliculado; gema terminal recoberta por pilosidade ferrugínea; ramos cilíndricos

84. Ramos jovens tomentosos

Guapira olfersiana

84'. Ramos jovens glabros

Guapira opposita

80'. Limbo foliar com pontuações translúcidas (olhar contra a luz) e/ou folhas odoríferas

85. Ramos jovens de cor verde, folhas com odor desagradável muito forte, ápice acuminado

85'. Sem o conjunto de caracteres

86. Folhas pilosas

87. Folhas elíticas, subsésseis (pecíolo menor que $0,5 \mathrm{~cm}$ compr.), base cordada

Myrcia tomentosa

87 '. Folhas largo-elíticas, pecioladas (pecíolo maior que 0,5cm compr.), base atenuada

Campomanesia guazumifolia

86'. Folhas glabras

88. Limbo foliar maior que $10 \mathrm{~cm}$ compr., nervuras terciárias salientes

88 '. Limbo foliar até $10 \mathrm{~cm}$ compr., nervuras terciárias imersas

89. Folhas lanceoladas, margem levemente revoluta

89'. Folhas elíticas, margem plana

90. Folhas membranáceas

Siparuna guianensis

90'. Folhas cartáceas ou coriáceas

91. Folhas cartáceas, ápice acuminado, pecíolo canaliculado

68 '. Folhas alternas

91'. Folhas coriáceas, ápice agudo, pecíolo cilíndrico

Myrcia pubipetala

Siphoneugenia regnelliana Myrciaria floribunda

92. Plantas latescentes

93. Folhas discolores, ápice arredondado

93'. Folhas concolores, ápice acuminado ou agudo

94. Folhas obovais, ápice acuminado, base cuneada. Eugenia florida Eugenia hiemalis

94'. Folhas elíticas ou oblongas, ápice agudo, base atenuada.

92'. Plantas não latescentes

95. Folhas com pulvino e pulvínulo, bifolioladas (folíolos unidos simulando folhas simples)...Bauhinia forficata 95'. Sem o conjunto de caracteres

96. Folhas dísticas

97. Folhas subsésseis (pecíolo menor que $0,5 \mathrm{~cm}$ compr.), base aguda

Guatteria australis

97'. Folhas pecioladas (pecíolo maior que $0,5 \mathrm{~cm}$ compr.), base arredondada ou cordada .....Xylopia aromatica

96'. Folhas espiraladas

98. Folhas pilosas

99. Margem foliar recortada

100. Base foliar assimétrica, limbo com pontuações translúcidas

101. Folhas com pilosidade na face inferior apenas ao longo da nervura central ..........Casearia sylvestris

101 '. Folhas com pilosidade em toda a face inferior. Casearia grandiflora

100'. Base foliar simétrica, limbo sem pontuações translúcidas 
102. Folhas discolores, actinódromas, pilosidade ferrugínea.

Luehea divaricata

102'. Folhas concolores, semicraspedródomas, pilosidade esbranquiçada ..... Symplocos pubescens 99'. Margem foliar íntegra

103. Folhas ovais, escabras na face superior, base assimétrica Cordia sellowiana

103'. Folhas obovais, não escabras, base simétrica

104. Pilosidade argêntea...

Croton floribundus

104'. Pilosidade ferrugínea

105. Folhas obovais, base obtusa, pêlos simples

Terminalia brasiliensis

105'. Folhas oblongas, base truncada, pêlos estrelados. Virola sebifera

98'. Folhas glabras

106. Presença de ramentas (Figura 3.3)

106'. Ausência de ramentas

107. Margem foliar recortada

108. Base foliar assimétrica, limbo com pontuações translúcidas.

108'. Base foliar simétrica, limbo sem pontuações translúcidas

109. Estípulas presentes, recobrindo as gemas (olhar ramos jovens)

09'. Estípulas ausentes

110. Folhas rômbicas, odoríferas, pecíolo maior que $3 \mathrm{~cm}$ compr.

110 '. Folhas elíticas ou oblongas, não odoríferas, pecíolo menor que $2 \mathrm{~cm}$ compr.

111. Folhas elíticas, base obtusa, margem serreada

Roupala montana

111'. Folhas oblongas, base atenuada, margem inciso-serreada..

...Ouratea semiserrata

107'. Margem foliar íntegra

112. Folhas rômbicas, odoríferas, pecíolo maior que $3 \mathrm{~cm}$ compr.

Ouratea castaneaefolia

112'. Folhas obovais, elíticas, largo-elíticas ou ovais, não odoríferas, pecíolo menor que

$2 \mathrm{~cm}$ compr.

113. Base do limbo foliar revoluta

114. Folhas elíticas, com domáceas nas axilas das nervuras secundárias da face inferior; sem escamas nos ramos jovens e nas folhas

Ocotea corymbosa

114'. Folhas obovais, sem domáceas; com pequenas escamas nos ramos jovens e na face inferior das folhas.

Pera glabrata

113'. Base do limbo foliar plana

115. Folhas com ápice acuminado e base atenuada, pecíolo escurecido ..... Nectandra megapotamica

$115^{\prime}$. Folhas com ápice e base agudos, pecíolo indistinto Actinostemon communis 


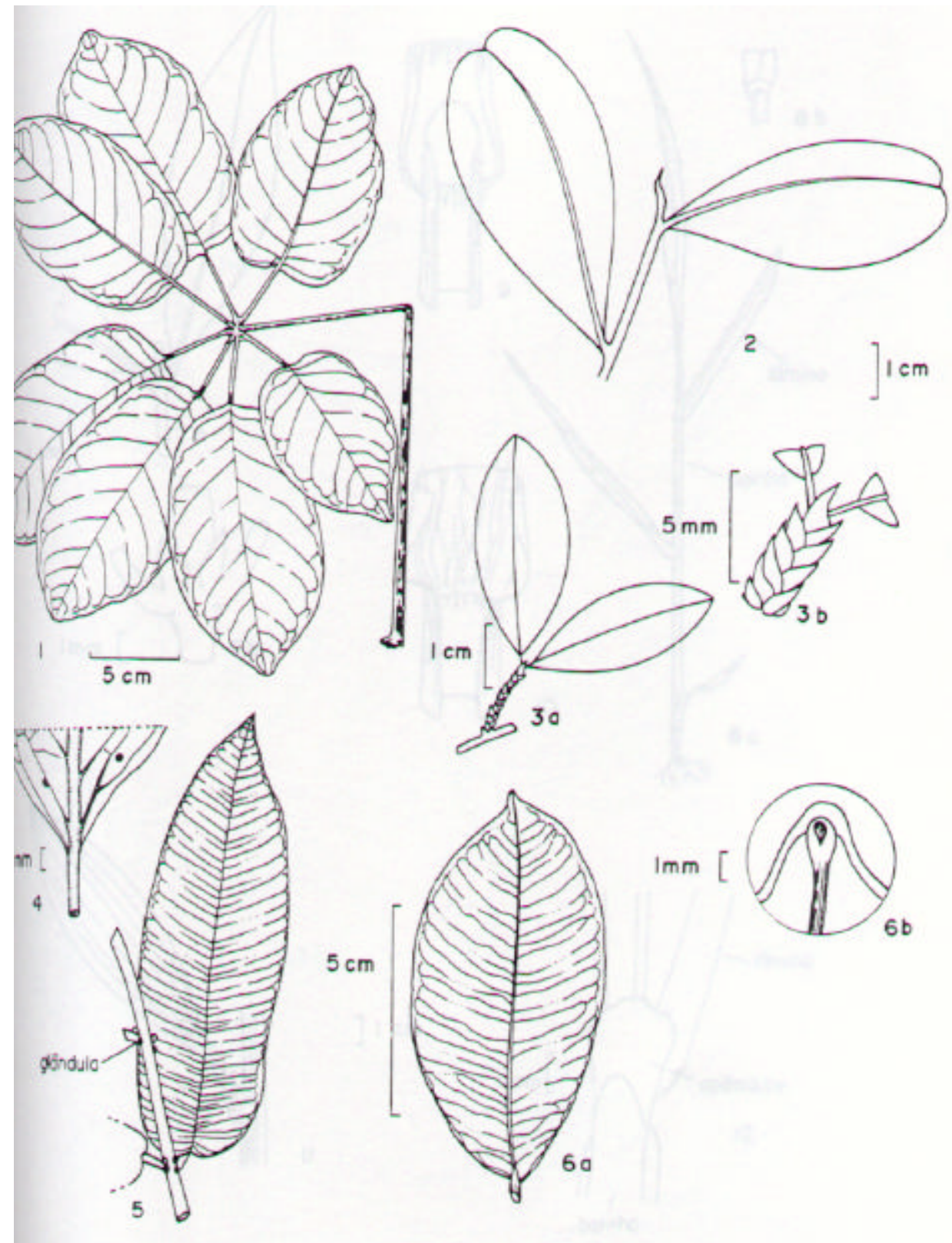

Figuras 3.1 a 3.6 - 1. Folíolos não articulados em Pseudobombax longiflorum (adaptado de Santos 1967); 2. Raque foliar terminada em pequeno apêndice em Magonia pubescens; 3. Erythroxylum cuneifolium: a) ramo, b) ramentas (segundo Batalha et al. aceito para publicação); 4. Nectários extra-florais na face inferior do limbo em Prunus sellowii (adaptado de Rossi 1994); 5. Base do pecíolo com glândula em Qualea grandiflora (adaptado de Mantovani et al. 1985); 6. Lafoensia pacari: a) folha, b) ápice foliar com glândula na face inferior do limbo (segundo Batalha et al. aceito para publicação). 


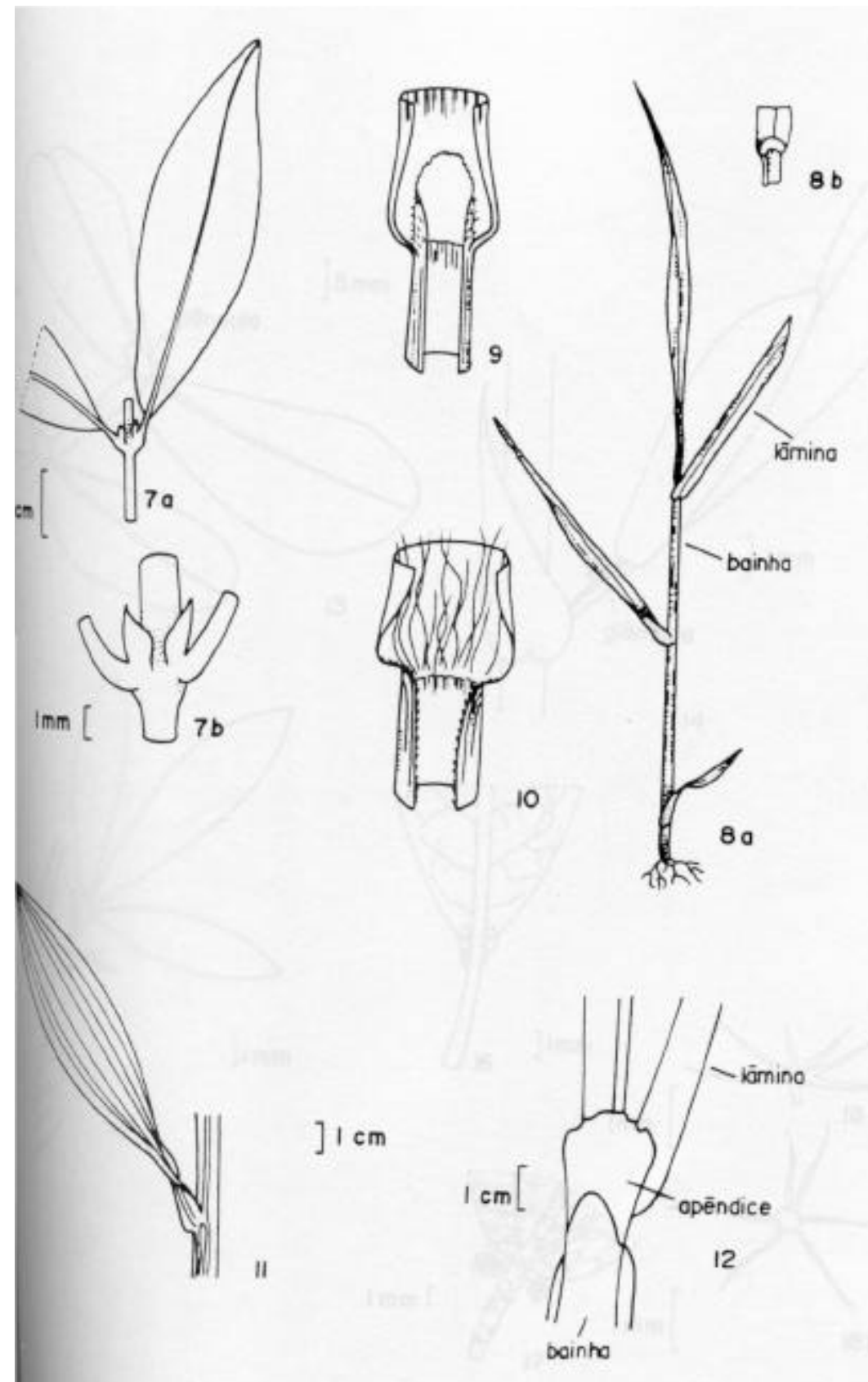

Figuras 3.7 a 3.12 - 7. Byrsonima intermedia: a) ramo, b) estípulas intrapeciolares (segundo Batalha et al. aceito para publicação); 8. Poaceae: a) folhas com bainha e lâmina, b) lígula (adaptado de Chase \& Sendulski 1991); 9. Lígula membranosa em Poaceae (adaptado de Dahlgren et al. 1985); 10. Lígula pilosa em Poaceae (adaptado de Dahlgren et al. 1985); 11. Lâmina foliar ressupinada em Alstroemeria pulchella; 12. Ápice da bainha apendiculado em Scleria comosa. 


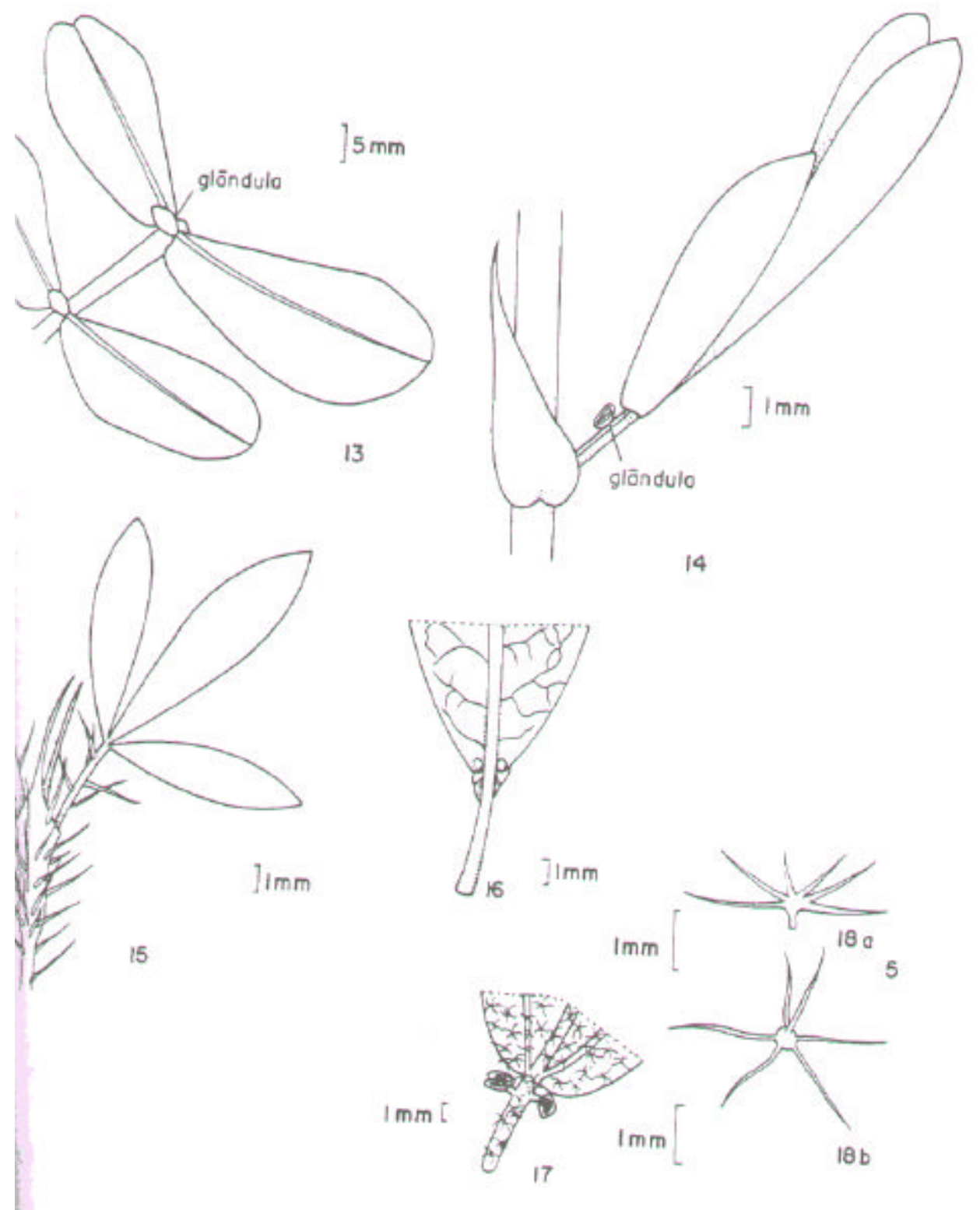

Figuras 3.13 a 3.18 - 13. Glândula clavada interjuga em Senna rugosa; 14. Glândula plateliforme em Chamaechrista desvauxii; 15. Estípulas soldadas formando pseudo-bainha em Stylosanthes guianensis; 16. Base da lâmina foliar com glândulas em Sapium glandulatum (adaptado de Rossi 1994); 17. Base foliar com glândulas estipitadas em Croton glandulosus (segundo Batalha et al. aceito para publicação); 18. Pêlo estrelado: a) vista lateral, b) vista dorsal (segundo Batalha et al. aceito para publicação). 


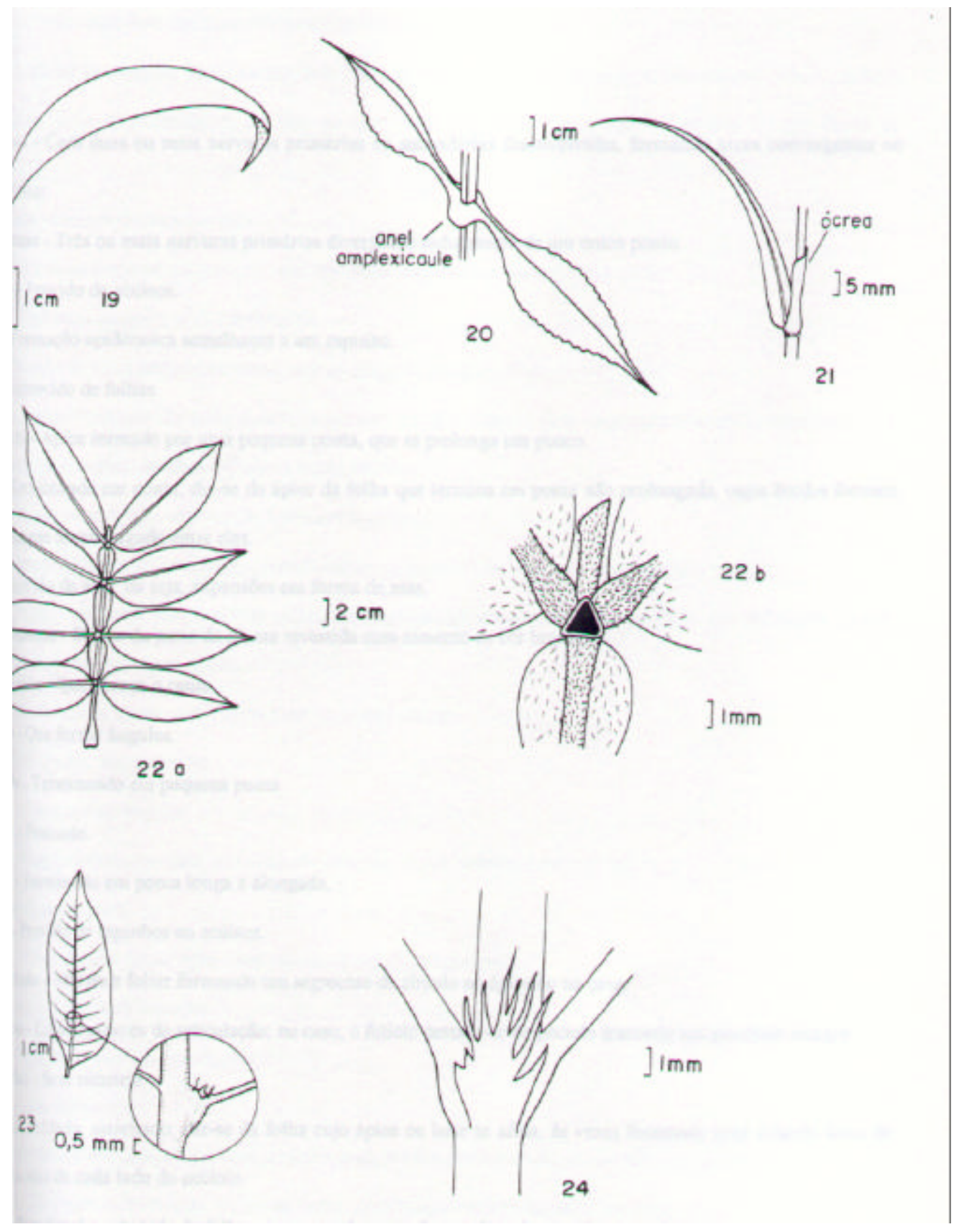

Figuras 3.19 a 3.24 - 19. Folha com bainha fechada em Commelina erecta; 20. Anel amplexicaule em Buddleja brasiliensis; 21. Ócrea em Polygonum acre; 22. Inga uruguensis: a) folha, b) raque foliar alada com glândulas interjugas; 23. Domáceas na face inferior do limbo foliolar em Cedrela fissilis (adaptado de Rossi 1994); 24. Estípulas com dentes subulados em Rudgea viburnoides. 
Glossário (adaptado de Ferri et al. 1969, Radford et al. 1974, Rizzini 1977, Mantovani et al. 1985)

Acródromo - Com duas ou mais nervuras primárias ou secundárias desenvolvidas, formando arcos convergentes no ápice foliar.

Actinódromo - Três ou mais nervuras primárias divergindo radialmente de um único ponto.

Aculeado - Provido de acúleos.

Acúleo - Formação epidérmica semelhante a um espinho.

Áfilo - Desprovido de folhas.

Acuminado - Ápice formado por uma pequena ponta, que se prolonga um pouco.

Agudo - Terminando em ponta; diz-se do ápice da folha que termina em ponta não prolongada, cujos bordos formam no ápice um ângulo agudo entre eles.

Alado - Provido de alas, ou seja, expansões em forma de asas.

Albo-tomentoso - Diz-se da parte da planta revestida com tomento de cor branca.

Amplexicaule - Que abraça o caule.

Anguloso - Que forma ângulos.

Apiculado - Terminando em pequena ponta.

Argênteo - Prateado.

Aristado - Terminado em ponta longa e alongada.

Armado - Provido de espinhos ou acúleos.

Arredondado - Margens foliar formando um segmento de círculo no ápice ou na base.

Articulado - Ligado através de articulação; no caso, o folíolo destaca-se do pecíolo trazendo seu peciólulo íntegro.

Assimétrico - Sem simetria.

Atenuado - Afilado, estreitado; diz-se da folha cujo ápice ou base se afina, às vezes formando uma delgada faixa de pecíolo (ala) de cada lado do pecíolo.

Bainha - Parte basal e achatada da folha, que a prende ao caule envolvendo-o total ou parcialmente.

Bipinado - Folhas duas vezes pinada.

Bipinatissecto - Folhas bipinada, mas o recorte dos foliólulos incompleto, chegando próximo da nervura central.

Broquidódromo - Com nervuras secundárias unidas em um série de arcos proeminentes. 
Bulado - Diz-se da superfície que apresenta protuberâncias em forma de bolhas.

Caméfita - Planta lenhosa ou herbácea que mantém a porção epígea durante todo o ano e cujos ramos maduros permancem até a $50 \mathrm{~cm}$ de altura, ou, caso cresçam mais que $50 \mathrm{~cm}$, morram periodicamente até este limite de altura.

Canaliculado - Provido de pequeno canal.

Carnoso - Diz-se do órgão ou parte vegetal que apresenta consistência mole, como a carne.

Cartáceo - Que tem consistência de papel-cartão.

Ciliado - Provido de pêlos pequenos e numerosos ao longo da margem foliar.

Circular - Diz-se da forma da folha simétrica regular, em que tanto o eixo longitudinal quanto o transversal têm tamanhos semelhantes, dando à folha uma forma circular.

Cladódio - Caule modificado, com função fotossintetizante.

Cladódromo - Com nervuras secundárias ramificando-se livremente em direção à margem foliar.

Clatrado - Diz-se da folha com nervuras primárias longitudinais e secundárias transversais que delimitam figuras retangulares, lembrando uma grade.

Clavado - Em forma de clava, com o ápice mais largo que a base.

Colmo - Caule de nós bem definidos.

Concolor - Que tem a mesma cor.

Congesto - Congestionado; no caso, as folhas são inseridas muito próximas entre si, perto do ápice do ramo, deixando nua grande parte deste.

Cordado - Diz-se da base foliar cujos lobos são arredondados e convexos.

Cordiforme - Em forma de coração.

Coriáceo - Que tem a consistência de couro.

Crasso - Grosso, suculento.

Crenado - De dentes arredondados. Diz-se da folha cujos bordos são recortados em dentes arredondados.

Crenulada - Diminutivo de crenado. Diz-se da folha crenada com recortes de pequenas dimensões.

Cuneado - Em forma de cunha. Margens foliares formando um ângulo entre $45^{\circ}$ e $90^{\circ}$.

Cuspidado - Terminando em ponta fina, mais ou menos alongada, podendo ser curva.

Decorrente - Folha cuja base se estende além do ponto de inserção no caule.

Decumbente - Que está deitado. Diz-se de caules deitados sobre o solo, com extremidades que se erguem.

Deltóide - Triangular, com o comprimento aproximadamente igual a largura. 
Denteado - Recortado em dentes; a rigor, dentes orientados perpendicularmnte ao eixo longitudinal.

Digitado - Que apresenta lobos alongados, semelhantes a dedos e que divergem a partir de um ponto.

Discolor - De cores diferentes.

Dístico - Dispostos em duas filas, em um único plano.

Domácea - Membrana de tecido que, na região axilar, une o início de duas nervuras do limbo foliar, formando uma pequena cavidade, que abriga um ou mais organismos em uma ou mais fases de seu ciclo de vida.

Elítico - Em forma de elipse. Com maior largura na metade do limbo e com as margens simetricamente curvadas, numa proporção entre comprimento e largura entre 2:1 e 3:2.

Emarginado - Ápice da folha que apresenta uma reentrância pouco profunda.

Epífita - Planta que cresce apoiando-se e enraizando-se sobre outra planta

Escabroso - Áspero ao tato, em decorrência da presença de pêlos rígidos e curtos.

Escama - Qualquer formação que lembre escamas de peixe.

Escandente - Planta que cresce apoiando-se em outras, enraizando-se no solo.

Espinescente - Provido de espinhos.

Espinho - Elemento pontiagudo, resultante da modificação de uma ramo, uma folha, uma estípula ou uma raiz, e, conseqüentemente, com elementos condutores.

Estipe - Caule comprido, quase cilíndrico, sem ramificações.

Estipelas - Escamas pareadas na base dos peciólulos.

Estipitado - Que tem estípite, ou seja, tronco colunar, pedúnculo ou pedicelo.

Estípulas - Formação laminar na base dos pecíolos.

Estípula foliácea - Estípula semelhante a uma folha.

Estípulas intrapeciolares - Estípula da mesma folha, soldadas entre si e ocorrentes entre o pecíolo e o caule.

Estípulas interpeciolares - Estípulas soldadas entre si e pertencentes a folhas diferentes e imediatas do mesmo nó.

Estreito-elítico - Com maior largura na metade do limbo, numa proporção entre comprimento e largura maior que 3:1.

Estrelado - Em forma de estrela, com raios projetando-se a partir do centro como raios de uma estrela.

Eucamptódromo - Com nervuras secundárias voltadas para o ápice foliar e diminuido gradualmente, conectadas às nervuras secundárias superadjacentes através de pequenas nervuras sem formar arcos proeminentes.

Exapendiculado - Desprovido de apêndice.

Excêntrico - Deslocado do centro. 
Fanerófita - Planta lenhosa ou herbácea que mantém a porção epígea durante todo o ano, que cresce mais que 50cm, ou cujos brotamentos não morrem periodicamente até este limite de altura.

Fenestrado - Com numerosas perfurações.

Ferrugíneo-tomentoso - Diz-se da parte da planta revestida com tomento de cor ferrugínea.

Filiforme - Com formato de fio, isto é, longo e delgado.

Fimbriado - Finamente recortado na margem, lembrando franjas.

Flocoso - Coberto com pêlos densos e adpressos, em tufos.

Geniculado - Dobrado em forma de joelho.

Geófita - Planta herbácea com redução periódica de todo o sistema de brotamento a orgãos de reserva que se mantêm imersos no solo.

Glabro - Desprovido de pêlos.

Glauco - De cor verde-clara ou azulada.

Hemicriptófita - Planta herbácea com redução periódica da porção epígea a um sistema subterrâneo que permanece próximo à superfície.

Hifódromo - Todas as nervuras, com exceção da primária, ausentes ou rudimentares.

Hirsuto - Coberto com pêlos longos, às vezes rígidos.

Híspido - Coberto com pêlos muito longos, rígidos.

Imerso - Diz-se da nervura que está no mesmo plano do limbo foliar.

Imparipinado - Folha composta pinada que tem um folíolo terminal na raque, isto é, o número de folíolos é impar.

Impresso - Diz-se da nervura que está afundada no limbo foliar.

Inciso-serreado - Diz-se da margem serreada, com recortes mais profundos.

Incurvado - Formando um arco voltado para o ápice.

Inerme - Desprovido de espinhos ou acúleos.

Inflado - Dilatado.

Jugo - Par de folíolos.

Lanceolado - Com a maior largura abaixo da metade do limbo e com as margens simetricamente curvadas, numa proporção de aproximadamante 3:1 entre comprimento e largura.

Lanuginoso - Coberto com pêlos entrelaçados, com textura semelhante a lã.

Largo-elítico - Com a maior largura na metade do limbo e com as margens simetricamente curvadas, numa proporção de 
6:5 entre comprimento e largura, aproximadamante.

Largo-oblongo - Com a maior largura na metade do limbo e com as margens paralelas, numa proporção de 6:5 entre comprimento e largura, aproximadamante.

Largo-oboval - Com a maior largura acima da metade do limbo e com as margens simetricamente curvadas, numa proporção de 6:5 entre comprimento e largura, aproximadamante.

Largo-oval - Com a maior largura abaixo da metade do limbo e com as margens simetricamente curvadas, numa proporção de 6:5 entre comprimento e largura, aproximadamante.

Largo-trulado - Com a maior largura abaixo da metade do limbo, mas com as margens retas, formando ângulos obtusos, numa proporção de 6:5 entre comprimento e largura, aproximadamante.

Laxo - Diz-se da disposição frouxa das folhas.

Lenticela - Pequena abertura, constituídas de células suberizadas e frouxamente agregadas, que permite trocas gasosas.

Lepidoto - Coberto com pêlos escamiformes.

Liana - Planta que cresce apoiando-se em outras, enraizando-se no solo.

Lígula - Apêndice que ocorre nas gramíneas entre a bainha e o limbo foliar.

Linear - Com a relação entre o comprimento e a largura maior que 12:1.

Linear-lanceolado - Com a maior largura abaixo da metade do limbo e com as margens simetricamente curvadas, numa proporção de aproximadamante 6:1 entre comprimento e largura.

Liso - Ausência quase total de fendilhamentos e protuberâncias.

Membranáceo - Diz-se do limbo foliar que tem consistência delicada e mole, como uma membrana.

Mucronado - Diz-se da folha cujo ápice termina de forma abrupta numa ponta curta chamada múcron.

Multijugo - Diz-se da folha composta pinada, constituída por muitos pares (jugos) de folíolos ao longo da raque. Se a folha é bipinada, um jugo representa um par de folíolos pinados.

Nectário extra-floral - Estrutura glandular produtora de néctar, localizada fora da flor.

Nervura - Um dos cordões, constituídos por feixes vasculares, paralelos ao eixo longitudinal da folha, poucos numerosos e escassamente ramificados, evidentes a olho nu.

Nó - Cada uma das regiões do caule, em que podem nascer ramos, folhas, etc.

Oblanceolado - Com a maior largura acima da metade do limbo e com as margens simetricamente curvadas, numa proporção de aproximadamante 3:1 entre comprimento e largura.

Oblongo - Diz-se da forma da folha simétrica regular, em que o eixo longitudinal é maior do que o tranversal, em uma proporção entre 2:1 e 3:2. O eixo transversal é quase uniforme ao longo do longitudinal, isto é, os bordos são quase 
paralelos na maior parte da extensão do limbo foliar, e freqüentemente tanto a base quanto o ápice são obtusos.

Oboval - Com a maior largura acima da metade do limbo, com a relação entre comprimento e largura em torno de 2:1 a $3: 2$

Obtuso - Diz-se da folha cujos bordos formam, no ápice, um ângulo obtuso ou que descrevem um segmento de círculo.

Ócrea - Formação com aspecto de bainha que envolve o caule, resultando do concrescimento de estípulas axilares em ambos os bordos.

Ondulado - Diz-se da folha que apresenta as margens onduladas, ainda que a maior parte do limbo seja plana.

Oval - Em forma de ovo. Com a maior largura abaixo da metade do limbo, com a relação entre comprimento e largura em torno de $2: 1$ a $3: 2$.

Palmatilobado - Com lobos distribuídos em forma de palma.

Paralelódromo - Com duas ou mais nervuras primárias paralelas entre si e entre a margem foliar.

Parasita - Planta heterotrófica.

Paripinado - Diz-se da folha composta pinada que tem número par de folíolos.

Patente - Diz-se do pêlo que forma ângulo muito aberto em relação à folha, ficando quase plano.

Pêlo - Formação epidérmica uni ou pluricelular, uni ou plurisserial, simples ou ramificada, pontiaguda ou capitada, etc, com diversas funções. Aqui utilizado como sinônimo de tricoma.

Piloso - Provido do pêlos.

Pinada - Diz-se da folha composta, subdividada em folíolos ou pinas.

Pinatífido - Com recorte chegando à metade da folha

Pinatissecto - Com recorte chegando próximo à nervura central.

Plateliforme - Em forma de prato.

Procumbente - Caule flexuoso, que não se mantém ereto, mas rasteja sobre o solo sem nele se enraizarem

Prostrado - Caule que se apresenta deitado sobre o solo.

Pubérulo - Minutamente pubescente.

Pubescente - Coberta de pêlos finos, curtos e suaves, dando ao toque uma sensação aveludada.

Pulvino - Dilatação do pecíolo

Pulvínulo - Dilatação do peciólulo.

Ramenta - Estípulas intrapeciolares triangulares, persistentes e imbricadas.

Raque - O eixo principal de uma folha composta. 
Recurvado - Formando um arco voltado para a base.

Ressupinado - Torcido. Diz-se da folha que sofre torção, tendo voltada para baixo a face que normalmente está voltada para cima, e vice-versa.

Reticulódromo - Com nervuras secundárias perdendo sua identidade em direção à margem foliar através de repetidas ramificações.

Revoluto - Bordos das folhas que são enrolados ou revirados para trás ou para baixo.

Rômbico - Com a maior largura na metade do limbo, mas com as margens retas, formando ângulos obtusos, numa proporção em torno de 2:1 e 3:2 entre comprimento e largura.

Rugoso - Tronco com aspecto enrugado, com fendas pequenas e pouco profundas.

Saculiforme - Em forma de saco.

Sagitado - Em forma de seta, isto é, pontiagudo com a base bilabiada, sendo os lobos igualmente pontiagudos.

Saliente - Diz-se da nervura que se sobressai em relação ao limbo foliar.

Sedoso - Com tricomas longos, sedosos, usualmente adpressos. O mesmo que seríceo.

Segmentos foliares - "Folíolos" das folhas das palmeiras, em que se distribuem uniformemente (segmentos eqüidistantes) ou agrupados em feixes (segmentos em fascículos).

Semicraspedódromo - Com nervuras secundárias ramificando-se em duas, um ramo terminando na margem foliar e o outro conectando-se à nervura secundária superadjacente.

Semi-parasita vascular - Planta semi-autotrófica.

Seríceo - Recoberto por pêlos macios e brilhantes, que dão ao tato uma sensação de seda. O mesmo que sedoso.

Serreado - Que apresenta recortes semelhantes ao de uma serra, com dentes de orientação em ângulo agudo em direção ao ápice.

Serrilhado - Minutamente serreado.

Sobolífero - Que produz ramos a partir de orgão subterrâneos.

Suberoso - Tronco com fendas muito grandes e profundas, formando placas ou costas muito espessas.

Subulado - Com forma que apresenta estreitamento em direção ao ápice até terminar em ponta fina.

Suculento - Diz-se de qualquer órgão vegetal, ou de uma de suas partes, quando espessos e carnosos, com muito suco.

Ternado - Folhas trifolioladas.

Terófita - Planta anual, cujas partes aéreas e subterrâneas morrem após a frutificação e que completa seu ciclo de vida em um ano. 
Tomentoso - Revestido por tomento, formado por pêlos simples ou ramificados, geralmente entrelaçados e muito densos, assemelhando-se à lã.

Trepadeira - Liana provida de gavinhas.

Tripinada - Folha três vezes pinada.

Tripinatissecto - Folhas tripinada, mas o recorte dos folíolos de terceira ordem incompleto, chegando próximo da nervura central.

Truncado - Diz-se da folha que parece ter sido cortada em uma das extremidades, com as margens formando ângulo reto no ápice ou na base.

Velutino - Coberto densamente com pêlos retos, longos e macios, que dão ao toque uma sensação aveludada.

Verticilado - Inserção das folhas no ramo, em que elas se inserem num mesmo nó em número maior que dois.

Volúvel - Liana desprovida de gavinhas, que sobe enrolando-se no suporte.

\section{Discussão}

Segundo Mantovani et al. (1985), os caracteres vegetativos variam mais do que os reprodutivos e, desta forma, para uma identificação precisa, vários ramos de vários indivíduos da espécie a ser identificada devem ser analisados. Deve-se procurar coletar ramos adultos, evitando-se ramos de brotamento e com galhas ou doenças devido às suas grandes variações de forma e textura. Na coleta, deve-se anotar características que serão perdidas no material herborizado, como hábito de crescimento, odor e coloração das folhas, presença de látex e características do sistema subterrâneo.

Durante a preparação das chaves, procurou-se utilizar para a separação das espécies caracteres de fácil diagnóstico, que não apresentassem grande plasticidade. Em alguns casos, todavia, as espécies puderam ser separadas, por exemplo, apenas pelo tamanho de determinada estrutura, que é um caráter plástico e não permite uma identificação segura.

Além disso, devido às variações encontradas na população, diversas espécies foram incluídas em mais de uma entrada nas chaves. 
A abrangência destas chaves de identificação é local e sua utilização em outras áreas pode levar a erros de identificação.

\section{Referências bibliográficas}

ARAGAKI, S. 1997. Florística e estrutura de trecho remanescente de floresta no Planalto paulistano (SP). Dissertação de Mestrado. Univ. S. Paulo.

BATAlHA, M. A.; ARAGAKI, S. \& MANTOVANI, W. Aceito para publicação. Chave de identificação baseada em caracteres vegetativos para as espécies do cerrado em Emas (Pirassununga, SP). Bol. Bot. Univ. S. Paulo.

CASTRO, A. A. J. F. 1987. Florística e fitossociologia de um cerrado marginal brasileiro, Parque Estadual de Vassununga, Santa Rita do Passa-Quatro, SP. Tese de Mestrado. Univ. Est. Campinas.

CHASE, A. \& SENDULSKY, T. 1991. Primeiro livro de gramíneas. São Paulo, Instituto de Botânica.

DAHLGREN, R.M.T., CLIFFORD, H.T. \& YEO, P.F. 1985. The families of the monocotyledons. Berlin, Springer-Verlag.

FERRI, M.G., MENEZES, N.L. \& SCANAVACCA, W.R.M. 1969. Glossário de termos botânicos. São Paulo, Edgard Blücher e EDUSP.

GARCIA, R. J. F. 1995. Composição florística dos estratos arbóreos e arbustivos da mata do Parque Santo Dias (São Paulo - SP, Brasil). Dissertação de Mestrado. Univ. S. Paulo.

MANTOVANI, W. 1987. Análise florística e fitossociológica do estrato herbáceo-subarbustivo do cerrado na reserva biológica de Moji Guaçu e em Itirapina, SP. Tese de Doutorado. Univ. Est. Camp. 
MANTOVANI, W., LEITÃO, G.F. \& MARTINS, F.R. 1985. Chave baseada em caracteres vegetativos para a identificação de espécies lenhosas do cerrado da Reserva Biológica de Moji Guaçu, Estado de São Paulo. Hoehnea 12: 35-56.

MUELLER-DUMBOIS, D. \& ELLENBERG, H. 1974. Aims and methods of vegetation ecology. New York, John Wiley \& Sons.

RADFORD, A. E., DICKSON, W. C., MASSEY, J. R. \& BELL, C. R. 1974. Vascular plants systematics. New York, Harper \& Row Publ.

RAUNKIAER, C. 1934. The life forms of plants and statistical geography. Oxford, Claredon.

RIZZINI, C.T. 1977. Sistematização terminológica da folha. Rodriguésia 29: 103-125.

ROSSI, L. 1994. A flora arbórea-arbustiva da mata da reserva da Cidade Universitária “Armando de Salles Oliveira" (São Paulo, Brasil). Bolm. Inst. Botânica 9: 1-105.

SANTOS, E. 1967. Bombacáceas. In: REITZ, R. (coord). Flora Ilustrada Catarinense. Itajaí, Herbário Barbosa Rodrigues.

VELOSO, H.P. 1945. As comunidades e estações botânicas de Teresópolis, estação do Rio de Janeiro (com um ensaio de uma chave dendrológica). Bolm. Museu Nac. 3: 1-95.

VELOSO, H.P. 1946. A vegetação no município de Ilhéus, estação da Bahia: II - Observações e ligeiras conclusões acerca de espécies que ocorrem na região. Chave analítica das espécies arbóreas. Mem. Inst. Osw. Cruz 44(2): 221-294. 
Anexo - Chave de identificação para as formas de vida encontradas na ARIE Cerrado Pé-deGigante (adaptada de Ellenberg \& Mueller-Dombois 1967 apud Mueller-Dombois \& Ellenberg 1974).

1. Plantas heterotróficas ou semi-autotróficas

2. Plantas heterotróficas Parasitas vasculares

2'. Plantas semi-autotróficas Semi-parasitas vasculares

1'. Plantas autotróficas

3. Plantas que crescem apoiando-se em outras

4. Plantas que se enraízam no solo Lianas

4'. Plantas que se enraízam sobre outras plantas Epífitas

3'. Plantas que não se apóiam em outras ao crescer

5. Plantas anuais, cujas partes aéreas e subterrâneas morrem após a frutificação e que completam seu ciclo de vida em um ano. Terófitas

5'. Plantas perenes

6. Plantas herbáceas com redução periódica da porção epígea

7. Redução da porção epígea periódica a um sistema radicular que permanece próximo à superfície Hemicriptófitas

7'. Redução periódica de todo o sistema de brotamento a orgãos de reserva que se mantêm imersos no solo. Geófitas

6'. Plantas lenhosas ou herbáceas que mantêm a porção epígea

8. Plantas cujos ramos maduros permancem até a $50 \mathrm{~cm}$ de altura, ou, caso cresçam mais que $50 \mathrm{~cm}$, morram periodicamente até este limite de altura Caméfitas 8'. Plantas que crescem mais que $50 \mathrm{~cm}$, ou cujos brotamentos não morram periodicamente até este limite de altura Fanerófitas 
Decorrente - Folha cuja base se estende além do ponto de inserção no caule.

Decumbente - Que está deitado. Diz-se de caules deitados sobre o solo, com extremidades que se erguem.

Deltóide - Triangular, com o comprimento aproximadamente igual a largura.

Denteado - Recortado em dentes; a rigor, dentes orientados perpendicularmnte ao eixo longitudinal.

Digitado - Que apresenta lobos alongados, semelhantes a dedos e que divergem a partir de um ponto.

Discolor - De cores diferentes.

Dístico - Dispostos em duas filas, em um único plano.

Domácea - Membrana de tecido que, na região axilar, une o início de duas nervuras do limbo foliar. formando uma pequena cavidade, que abriga um ou mais organismos em uma ou mais fases de seu ciclo de vida.

Elítico - Em forma de elipse. Com maior largura na metade do limbo e com as margens simetricamente curvadas, numa proporção entre comprimento e largura entre $2: 1$ e $3: 2$.

Emarginado - Ápice da folha que apresenta uma reentrância pouco profunda.

Epifita - Planta que cresce apoiando-se e enraizando-se sobre outra planta

Escabroso - Áspero ao tato, em decorrência da presença de pêlos rígidos e curtos.

Escama - Qualquer formação que lembre escamas de peixe.

Escandente - Planta que cresce apoiando-se em outras, enraizando-se no solo.

Espinescente - Provido de espinhos.

Espinho - Elemento pontiagudo, resultante da modificação de uma ramo, uma folha, uma estipula ou uma raiz, e, conseqüentemente, com elementos condutores.

Estipe - Caule comprido, quase cilíndrico, sem ramificações.

Estipelas - Escamas pareadas na base dos peciólulos.

Estipitado - Que tem estípite, ou seja, tronco colunar, pedúnculo ou pedicelo.

Estípulas - Formação laminar na base dos peciolos.

Estipula foliácea - Estipula semelhante a uma folha.

Estípulas intrapeciolares - Estipula da mesma folha, soldadas entre si e ocorrentes entre o peciolo e o caule.

Estipulas interpeciolares - Estípulas soldadas entre si e pertencentes a folhas diferentes e imediatas do mesmo nó.

Estreito-elítico - Com maior largura na metade do limbo, numa proporção entre comprimento e largura maior que 


\section{Fitossociologia de fissionomias da vegetação na ARIE Cerrado Pé-de-Gigante (Santa Rita do Passa Quatro, SP).}

Resumo - No presente trabalho, estudou-se uma área de vegetação natural, de 1269ha, situada no munícipio de Santa Rita do Passa Quatro, estado de São Paulo (21 $36-44^{\prime}$ S e $\left.47^{\circ} 34-41^{\prime} W\right)$. Foram lançadas aleatoriamente parcelas nas fisionomias de cerrado, cerradão, cerrado "sensu stricto" e campo cerrado, e na floresta estacional semidecídua, cujos tamanhos e critérios de inclusão foram diferentes em função de variações no componente lenhoso. Neste componente, as espécies com maiores valores de importância foram: Anadenanthera falcata, Pterodon pubescens, Copaifera langsdorfii, Pouteria ramiflora e Xylopia aromatica, no cerradão; Myrcia lingua, Xylopia aromatica, Dyptichandra aurantiaca, Miconia albicans e Anadenanthera falcata, no cerrado "sensu stricto"; Pouteria torta, Anadenanthera falcata, Miconia albicans, Byrsonima intermedia e Ouratea spectabilis, no campo cerrado; e Platypodium elegans, Croton floribundus, Tabebuia serratifolia, Machaerium villosum e Anadenanthera macrocarpa, na floresta estacional semidecídua. A biomassa, estimada pelo volume cilíndrico total, aumentou do campo cerrado à floresta estacional semidecídua, com valores intermediários no cerrado "sensu stricto" e no cerradão. O cerrado, em suas três fisionomias, apresentou não só grande diversidade $\alpha$, como também altas diversidades $\beta$ e $\gamma$.

Palavras-chave: cerrado, savana, floresta estacional semidecídua, fitossociologia, fisionomia, Pé-de-Gigante

Abstract - A natural vegetation area, with 1269ha, located at Santa Rita do Passa Quatro municipality, São Paulo State $\left(21^{\circ} 36-44^{\prime} \mathrm{S}\right.$ e $\left.47^{\circ} 34-41^{\prime} \mathrm{W}\right)$, southeastern Brazil, was studied. Quadrats were randomly sampled in the cerrado (a savanna-like ecosystem) physiognomies, cerradão, cerrado "sensu stricto" and campo cerrado, and in the seasonal semidecidous forest, with different sizes and inclusion criteria according to its woody component. In this component, the most important species were: Anadenanthera falcata, Pterodon pubescens, Copaifera langsdorfii, Pouteria ramiflora and Xylopia aromatica, in cerradão; Myrcia lingua, Xylopia aromatica, Dyptichandra aurantiaca, Miconia albicans and Anadenanthera falcata, in cerrado "sensu stricto"; Pouteria torta, Anadenanthera falcata, Miconia albicans, Byrsonima intermedia and Ouratea spectabilis, in campo cerrado; and Platypodium elegans, Croton floribundus, Tabebuia serratifolia, Machaerium villosum and Anadenanthera macrocarpa, in seasonal semidecidous forest. Biomass, estimated by total cylindric volume, increased from campo cerrado to seasonal semidecidous forest, with intermediate values in cerrado "sensu stricto" and cerradão. Cerrado, on its three physiognomies, showed high $\alpha$ diversity 
as well as $\beta$ and $\gamma$ ones.

Key words: cerrado, savanna, seasonal semidecidous forest, phytosociology, physiognomy, southeastern Brazil.

\section{Introdução}

Originalmente, cerca de $23 \%$ do território brasileiro, aproximadamente dois milhões de quilômetros quadrados, eram ocupados por vegetação de cerrado (Ratter 1992). Esta vegetação é encontrada principalmente em Minas Gerais, Mato Grosso, Mato Grosso do Sul, Goiás e Tocantins (Mantovani \& Martins 1993).

No estado de São Paulo, aparecem áreas disjuntas de cerrado (Eiten 1970). Em 1962, havia 143.700ha de cerradão, 1.384.450ha de cerrado "sensu stricto" e 309.000ha de campo cerrado (Chiarini \& Coelho 1972). Um levantamento realizado entre 1990 e 1992 (Instituto Florestal 1993) indicou que a cobertura vegetal era composta por 73.202ha de cerradão, 208.586ha de cerrado "sensu stricto" e 1.834ha de campo cerrado. Isto significa uma redução de 49,1\% de cerradão, 84,9\% de cerrado "sensu stricto" e 99,4\% de campo cerrado. Atualmente, o ecossistema de cerrado é o segundo bioma brasileiro mais ameaçado por atividades antrópicas (Spellerberg 1992).

No cerrado, análises fitossociológicas foram feitas por Goodland (1969), no Triângulo Mineiro; Picollo et al. (1971), em Corumbataí; Oliveira e Souza (1977), em Itirapina; Batista (1982), em MogiGuaçu; Oliveira Filho (1984), em Planaltina; Toledo Filho (1984), em Luiz Antônio; Ribeiro et al. (1985), em Planaltina; Mantovani (1987), em Mogi Guaçu e Itirapina; Cesar et al. (1988), em Corumbataí; Gianotti (1988), em Itirapina; Pagano et al. (1989), em Corumbataí; Cavassan (1990), em Bauru; Meira-Neto (1991), em Águas de Santa Bárbara; Nascimento \& Saddi (1992), em Cuiabá; Vincent et al. (1992), em Pirassununga e Felfili et al. (1994), na Chapada Pratinha.

Além destes trabalhos, Castro (1987) realizou uma análise fitossociológica na ARIE (Área de 
Relevante Interesse Ecológico) Cerrado Pé-de-Gigante, em que estudou o cerradão. Posteriormente, este autor comparou-a com outra área marginal de cerrado no Piauí (Castro 1994).

Em São Paulo, entremeadas às manchas de cerrado existem áreas cobertas por floresta estacional semidecídua, que cobrem grande parte do interior do estado. Esta floresta também é encontrada nos estados de Minas Gerais, Mato Grosso, Mato Grosso do Sul, Goiás, Bahia e Paraná (Veloso et al. 1991, Salis et al. 1995). Análises fitossociológicas em floresta estacional foram feitas por Cavassan et al. (1984), em Bauru; Pagano \& Leitão-Filho (1987), em Rio Claro; Matthes et al. (1988), em Campinas; Catharino (1989), em Piracicaba; Pinto (1989), em Jaboticabal; Rodrigues et al. (1989), em Jundiaí; Silva (1989), em São José dos Campos; Cesar \& Leitão-Filho (1990), em Anhembi; Gabriel (1990), em Botucatu; Nicolini (1990), em Jaú; Gandolfi (1991), em Guarulhos; Martins (1991), em Santa Rita do Passa Quatro; Kotchetkoff-Hendriques \& Joly (1994), em Itirapina e Pagano et al. (1995), em Rio Claro.

Este trabalho tem por objetivo a caracterização fitossociológica de trecho de floresta estacional semidecídua e das fisionomias de cerrado mais representativas da ARIE Cerrado Pé-de-Gigante, a partir do que se analisa a heterogeneidade estrutural do fragmento. Complementando as informações obtidas através das análises florísticas e fenológicas (Capítulos 2 e 5), a comparação da estrutura destas fisionomias procura fornecer subsídios aos trabalhos desenvolvidos na área e ao seu plano de manejo, permitindo seu zoneamento, a compreensão de sua dinâmica e de suas interrelações locais e regionais.

\section{Material e métodos}

\section{Área de estudo}


A Área de Relevante Interesse Ecólogico (ARIE) Cerrado Pé-de-Gigante está localizada no município de Santa Rita do Passa Quatro, estado de São Paulo, entre as coordenadas 21³6-44'S e 47³4-41'W, sob clima Cwag' de Köppen, em cotas altimétricas de 660 a 730m e sobre latossolo Vermelho-Amarelo fase arenosa (Castro 1987). A área estudada possui 1269ha, dos quais 1060ha constituem a ARIE Cerrado Pé-de-Gigante. Em seu interior, existem variações fisionômicas de cerrado que vão desde o campo sujo ao cerradão, além de mata ciliar, floresta estacional semidecídua e campo de várzea. Para uma caracterização mais detalhada da área, ver o Capítulo 1.

\section{Metodologia}

Foram conduzidos levantamentos fitossociológicos nas principais fisionomias da ARIE Pé-deGigante, cerradão, cerrado "sensu stricto", campo cerrado e floresta estacional semidecídua.

Pelo método de parcelas (Mueller-Dombois \& Ellenberg 1974), lançadas ao acaso no interior de cada fisionomia (Figura 4.1), a partir do mapeamento da ARIE elaborado por Mesquita Jr. (em andamento), foram obtidas amostras dos componentes herbáceo-subarbustivo e arbustivo-arbóreo. Os pontos foram sorteados na imagem digitalizada e, uma vez obtidas suas coordenadas, procurouse, com o auxílio de um GPS (Global Positioning System), chegar o mais próximo possível destes.

O tamanho das parcelas e o critério de inclusão foram diferentes em função de variações no componente dominante de cada uma das fisionomias. Assim, no campo cerrado, em que o componente herbáceo-subarbustivo é dominante, e no cerrado "sensu stricto", em que predominam arbustos e arvoretas, foram lançadas dez parcelas de 4 x 10m (0,004ha) e subparcelas de 1 x $2,5 \mathrm{~m}$ (0,00025ha). Na parcela maior, foram amostrados os indivíduos lenhosos com o diâmetro do caule igual ou superior a $1 \mathrm{~cm}$ na base, enquanto que na menor foram medidos os indivíduos lenhosos com diâmetros do caule na base até $0,9 \mathrm{~cm}$ e todos os não-lenhosos. No cerradão e na floresta 
estacional, em que as árvores de grande porte constituíam o componente dominante, foram lançadas dez parcelas de $10 \times 25 \mathrm{~m}$ (0,025ha), com subparcelas de 4 × $10 \mathrm{~m}(0,004 \mathrm{ha})$ e de 1 × $2,5 \mathrm{~m}$ (0,00025ha). Na primeira parcela, foram amostrados os indivíduos lenhosos com o diâmetro do caule igual ou superior a $10 \mathrm{~cm}$ no nível do solo, na segunda foram incluídos indivíduos lenhosos com diâmetro do caule no nível do solo entre 1 e 9,9cm e, na última, amostraram-se os indivíduos lenhosos com diâmetro do caule na base até $0,9 \mathrm{~cm}$ e todos os não-lenhosos. A dominância das espécies herbáceas foi calculada a partir do diâmetro no nível do solo, o que pode ter provocado superestimativas deste parâmetro, no caso das entouceiradas, e subestimativas, no caso das procumbentes e decumbentes. Os ramos das espécies sobolíferas foram considerados como pertencentes a um único indivíduo. Da mesma forma, os perfilhos das gramíneas em touceiras também foram considerados de um só indivíduo. $\mathrm{Na}$ parcela menor, procurou-se evitar a amostragem de plântulas, pela dinâmica que apresentam ao longo do ano.

O material botânico foi coletado, prensado, seco em estufa e identificado por comparação com o material coletado fértil e através de chaves de identificação baseadas em caracteres vegetativos (Mantovani et al. 1985, Mantovani 1987, Capítulo 3).

Os parâmetros considerados na análise fitossociológica foram: freqüência, densidade e dominância, de acordo com Mueller-Dombois \& Ellenberg (1974). Para o cálculo dos parâmetros relativos e dos valores de cobertura e importância foi utilizado o programa Fitopac (Shepherd 1994). O volume cilíndrico total foi calculado segundo Castro (1987). Foram também calculados os índices de diversidade de Shannon (Shannon \& Weaver 1963), equabilidade (Pielou 1975) e similaridade (Sørensen 1948, Bray \& Curtis 1957). Para o índice de similaridade de Bray-Curtis, foi utilizada a densidade relativa para quantificar as semelhanças entre as fisionomias. 


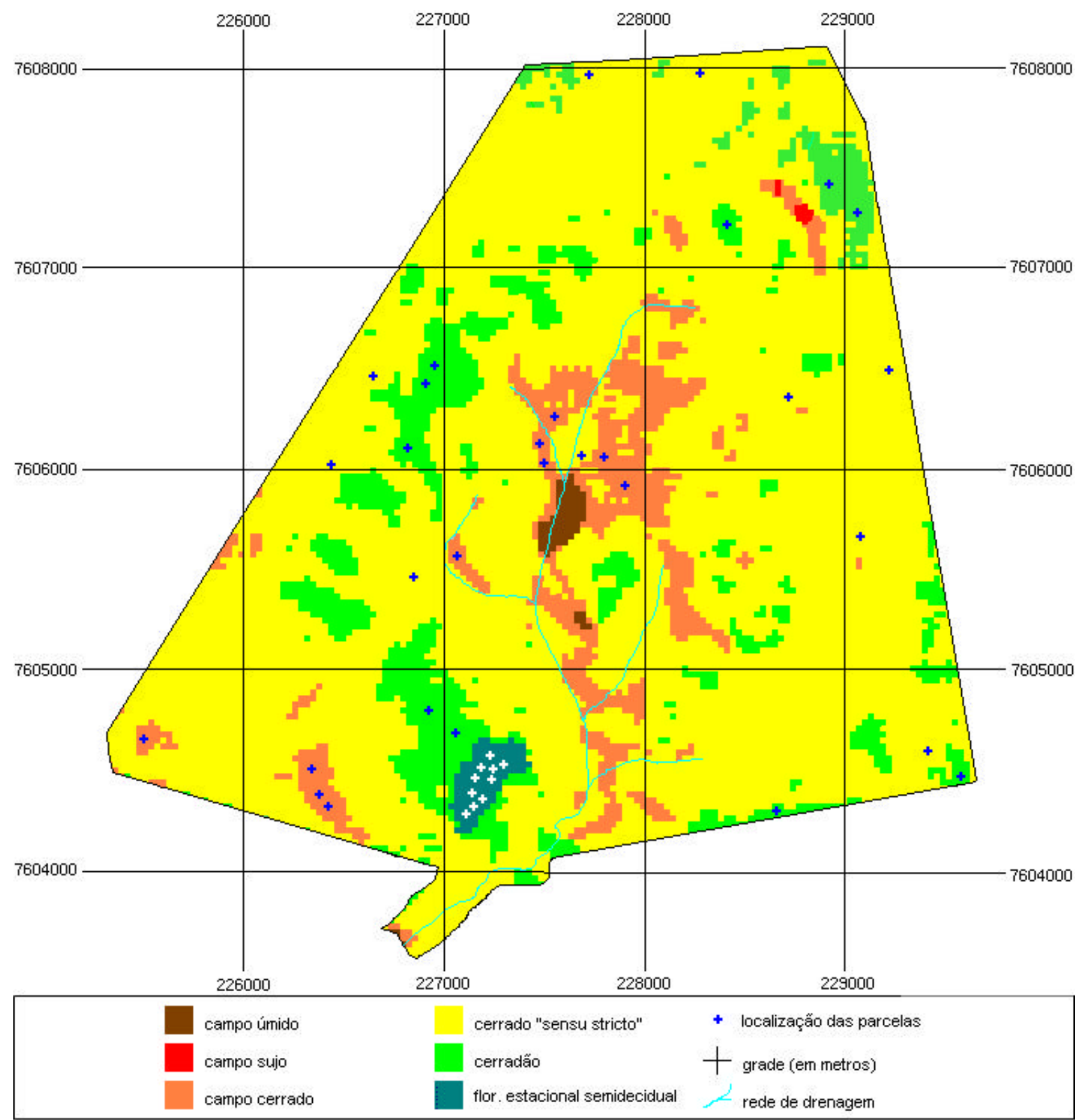

Figura 4.1 - Localização aproximada das parcelas na ARIE Cerrado Pé-de-Gigante, Santa Rita do Passa Quatro, São Paulo (2136-44'S e 47³4-41'W). 


\section{Resultados e discussão}

\section{Parâmetros fitossociológicos}

\section{Cerradão}

As espécies amostradas no cerradão, ordenadas pelo valor de importância (VI), estão reunidas nas Tabelas 4.1 (indivíduos lenhosos com mais de $10 \mathrm{~cm}$ de diâmetro basal), 4.2 (indivíduos lenhosos com diâmetro basal entre 1 e $9,9 \mathrm{~cm}$ ) e 4.3 (indivíduos lenhosos com até $0,9 \mathrm{~cm}$ de diâmetro basal e não-lenhosos).

Nas parcelas maiores (Tabela 4.1), foram amostrados 365 indivíduos, representando 42 espécies e 23 famílias. As espécies com maiores valores de importância foram, pela ordem, Anadenanthera falcata, Pterodon pubescens, Copaifera langsdorfii, Pouteria ramiflora e Xylopia aromatica, que perfizeram 40,67\% do total. Comparando-se os valores de cobertura com os valores de importância, notam-se algumas diferenças na ordenação das espécies: Vochysia cinamommea e Tapirira guianensis apresentaram valores de cobertura mais altos que de importância, o que indica um padrão mais agregrado de distribuição espacial. Myrcia lingua, por outro lado, teve valor de cobertura bem menor que o de importância, conseqüência de sua baixa dominância relativa, uma vez que a espécie é típica do componente intermediário. Das 42 espécies amostradas, 9 foram representadas por apenas um indivíduo. As famílias com maiores riquezas de espécies foram Fabaceae e Vochysiaceae, com 5 espécies cada uma, e Annonaceae, Caesalpiniaceae e Myrtaceae, representadas por 3 espécies cada.

Nas parcelas intermediárias (Tabela 4.2), foram amostrados 406 indivíduos, compreendendo 70 espécies e 30 famílias. As espécies com maiores valores de importância foram Myrcia lingua, 
Xylopia aromatica, Virola sebifera, Dyptichandra aurantiaca e Pouteria ramiflora, que representaram 36,23\% do total. Para Virola sebifera, o valor de cobertura foi excepcionalmente maior que o de importância, o que reflete um padrão de distribuição extremamente agregado, provavelmente conseqüência de reprodução vegetativa. Neste componente, Vochysia cinamommea também apresentou valor de cobertura bem maior que o de importância. Foram representadas por um único indivíduo 22 espécies. Fabaceae foi a família mais rica neste componente, com 7 espécies, seguindo-se Caesalpiniaceae (5), Myrtaceae (5), Rubiaceae (4) e Vochysiaceae (4).

No levantamento fitossociológico realizado nesta fisionomia por Castro (1987), foram amostrados 4.178 indivíduos com diâmetro basal igual ou superior a $3 \mathrm{~cm}$, distribuídos em 83 espécies, 64 gêneros e 35 famílias.

Comparando-se os resultados aqui obtidos para os componentes dominante e intermediário com aqueles de Castro (1987), pelo índice de Bray-Curtis, encontramos um valor de 0,284. Embora os critérios de inclusão sejam diferentes (diâmetro basal do caule maior que $3 \mathrm{~cm}$ para este autor e maior que $1 \mathrm{~cm}$ no presente estudo), este baixo valor mostra a heterogeneidade do cerrado dentro de uma mesma fisionomia.

Nas parcelas menores (Tabela 4.3), por sua vez, foram amostrados 301 indivíduos, pertencentes a 65 espécies e 35 famílias. Rhynchospora exaltata foi a espécie mais importante, com 27,45\% do VI. A esta espécie seguiram-se Myrcia lingua, Loudetiopsis chrysothrix, Styrax ferrugineus e Memora peregrine, que perfizeram $20,51 \%$ do valor de importância total. Loudetiopsis chrysothrix e Copaifera langsdorfii com, respectivamente, 6 e 23 indivíduos em uma única parcela foram as espécies que mais de distinguiram quando se compararam os valores de cobertura com os de importância. Entre as dez populações com maiores densidades, encontram-se espécies dos componentes dominante e intermediário, como Myrcia lingua, Styrax ferrugineus, Copaifera langsdorfii, Dyptichandra aurantiaca, Rourea induta e Ocotea corymbosa, o que indica um 
potencial regenerante para estas populações. Das 65 espécies, 26 foram amostradas somente uma vez. As famílias com maiores riquezas em espécie foram Poaceae e Myrtaceae, cada uma com cinco espécies, e Fabaceae e Rubiaceae, com 4 espécies cada.

Tabela 4.1 - Parâmetros fitossociológicos dos indivíduos das espécies lenhosas com diâmetro basal igual ou superior a $10 \mathrm{~cm}$ em cerradão na ARIE Cerrado Pé-de-Gigante, Santa Rita do Passa Quatro, São Paulo (21³6-44'S e 47³441’W), ordenados segundo o valor de importância. Legenda: no. ind. - número de indivíduos; Oc - ocorrência; $\mathrm{AB}=$ área basal $\left(\mathrm{m}^{2}\right)$; DR - densidade relativa (\%); DoR - dominância relativa (\%); FR - frequiência relativa (\%); VC = valor de cobertura (\%); VI - valor de importância (\%).

\begin{tabular}{|c|c|c|c|c|c|c|c|c|}
\hline espécie & no. ind. & Oc & $\mathbf{A B}$ & DR & DoR & FR & VC & VI \\
\hline Anadenanthera falcata & 45 & 8 & 1,0076 & 12,33 & 13,70 & 5,76 & 13,02 & 10,60 \\
\hline Pterodon pubescens & 37 & 9 & 0,9990 & 10,14 & 13,58 & 6,47 & 11,86 & 10,07 \\
\hline Copaifera langsdorfii & 29 & 8 & 0,5329 & 7,95 & 7,25 & 5,76 & 7,60 & 6,98 \\
\hline Pouteria ramiflora & 27 & 9 & 0,4481 & 7,40 & 6,09 & 6,47 & 6,75 & 6,66 \\
\hline Xylopia aromatica & 30 & 8 & 0,3760 & 8,22 & 5,11 & 5,76 & 6,67 & 6,36 \\
\hline Caryocar brasiliense & 15 & 8 & 0,4436 & 4,11 & 6,03 & 5,76 & 5,07 & 5,30 \\
\hline Dyptichandra aurantiaca & 20 & 7 & 0,2904 & 5,48 & 3,95 & 5,04 & 4,72 & 4,82 \\
\hline Qualea grandiflora & 14 & 5 & 0,3719 & 3,84 & 5,06 & 3,60 & 4,45 & 4,16 \\
\hline Vochysia cinamommea & 20 & 3 & 0,3008 & 5,48 & 4,09 & 2,16 & 4,79 & 3,91 \\
\hline Tapirira guianensis & 9 & 1 & 0,5782 & 2,47 & 7,86 & 0,72 & 5,17 & 3,68 \\
\hline Myrcia lingua & 13 & 7 & 0,1466 & 3,56 & 1,99 & 5,04 & 2,78 & 3,53 \\
\hline Plathymenia reticulata & 13 & 4 & 0,2683 & 3,56 & 3,65 & 2,88 & 3,61 & 3,36 \\
\hline Bowdichia virgilioides & 7 & 5 & 0,2443 & 1,92 & 3,32 & 3,60 & 2,62 & 2,95 \\
\hline Ouratea spectabilis & 10 & 4 & 0,1660 & 2,74 & 2,26 & 2,88 & 2,50 & 2,63 \\
\hline Dalbergia miscolobium & 7 & 5 & 0,1516 & 1,92 & 2,06 & 3,60 & 1,99 & 2,53 \\
\hline Qualea multiflora & 6 & 3 & 0,1048 & 1,64 & 1,43 & 2,16 & 1,54 & 1,74 \\
\hline Vatairea macrocarpa & 5 & 4 & 0,0686 & 1,37 & 0,93 & 2,88 & 1,15 & 1,73 \\
\hline Eriotheca gracilipes & 4 & 3 & 0,0837 & 1,10 & 1,14 & 2,16 & 1,12 & 1,46 \\
\hline Byrsonima coccolobifolia & 5 & 2 & 0,0944 & 1,37 & 1,28 & 1,44 & 1,33 & 1,36 \\
\hline Annona crassiflora & 4 & 3 & 0,0515 & 1,10 & 0,70 & 2,16 & 0,90 & 1,32 \\
\hline Pouteria torta & 5 & 2 & 0,0646 & 1,37 & 0,88 & 1,44 & 1,13 & 1,23 \\
\hline Annona coriacea & 3 & 3 & 0,0380 & 0,82 & 0,52 & 2,16 & 0,67 & 1,17 \\
\hline Qualea parviflora & 3 & 2 & 0,0447 & 0,82 & 0,61 & 1,44 & 0,72 & 0,96 \\
\hline Myrcia bella & 5 & 1 & 0,0470 & 1,37 & 0,64 & 0,72 & 1,01 & 0,91 \\
\hline Aspidosperma tomentosum & 3 & 2 & 0,0325 & 0,82 & 0,44 & 1,44 & 0,63 & 0,90 \\
\hline Ocotea corymbosa & 3 & 2 & 0,0260 & 0,82 & 0,35 & 1,44 & 0,59 & 0,87 \\
\hline Machaerium acutifolium & 2 & 2 & 0,0368 & 0,55 & 0,50 & 1,44 & 0,53 & 0,83 \\
\hline Kielmeyera variabilis & 2 & 2 & 0,0347 & 0,55 & 0,47 & 1,44 & 0,51 & 0,82 \\
\hline Roupala montana & 2 & 2 & 0,0294 & 0,55 & 0,40 & 1,44 & 0,48 & 0,80 \\
\hline Hymenaea stigonocarpa & 2 & 2 & 0,0224 & 0,55 & 0,30 & 1,44 & 0,43 & 0,76 \\
\hline Tabebuia ochracea & 2 & 2 & 0,0209 & 0,55 & 0,28 & 1,44 & 0,42 & 0,76 \\
\hline Qualea dichotoma & 2 & 1 & 0,0528 & 0,55 & 0,72 & 0,72 & 0,64 & 0,66 \\
\hline Connarus suberosus & 2 & 1 & 0,0341 & 0,55 & 0,46 & 0,72 & 0,51 & 0,58 \\
\hline Miconia rubiginosa & 1 & 1 & 0,0311 & 0,27 & 0,42 & 0,72 & 0,35 & 0,47 \\
\hline Erythroxylum campestre & 1 & 1 & 0,0172 & 0,27 & 0,23 & 0,72 & 0,25 & 0,41 \\
\hline Coussarea hydrangeaefolia & 1 & 1 & 0,0165 & 0,27 & 0,22 & 0,72 & 0,25 & 0,41 \\
\hline Banisteriopsis variabilis & 1 & 1 & 0,0161 & 0,27 & 0,22 & 0,72 & 0,25 & 0,40 \\
\hline Kielmeyera rubriflora & 1 & 1 & 0,0154 & 0,27 & 0,21 & 0,72 & 0,24 & 0,40 \\
\hline Guapira noxia & 1 & 1 & 0,0154 & 0,27 & 0,21 & 0,72 & 0,24 & 0,40 \\
\hline
\end{tabular}


Eugenia livida

Erythroxylum tortuosum

$\begin{array}{ll}0,0109 & 0,27 \\ 0,0097 & 0,27 \\ 0,0092 & 0,27\end{array}$

0,15

0,72

0,21

0,38

Virola sebifera

0,13

0,72

0,20

0,38

1

0,13

0,72

0,20

0,37

Tabela 4.2 - Parâmetros fitossociológicos dos indivíduos das espécies lenhosas com diâmetro basal entre 1 e 9,9cm em cerradão na ARIE Cerrado Pé-de-Gigante, Santa Rita do Passa Quatro, São Paulo (2136-44'S e 47³4-41'W), ordenados segundo o valor de importância. Legenda: no. ind. - número de indivíduos; Oc - ocorrência; $\mathrm{AB}=$ área basal $\left(\mathrm{m}^{2}\right)$; DR - densidade relativa (\%); DoR - dominância relativa (\%); FR - freqüência relativa (\%); VC = valor de cobertura (\%); VI - valor de importância (\%).

\begin{tabular}{|c|c|c|c|c|c|c|c|c|}
\hline espécie & no. ind. & Oc & $\mathbf{A B}$ & DR & DoR & FR & $\mathrm{VC}$ & VI \\
\hline Myrcia lingua & 44 & 10 & 0.0905 & 10,84 & 13,35 & 5,56 & 12,10 & 9,91 \\
\hline Xylopia aromatica & 41 & 8 & 0.0771 & 10,10 & 11,37 & 4,44 & 10,74 & 8,64 \\
\hline Virola sebifera & 44 & 3 & 0.0569 & 10,84 & 8,40 & 1,67 & 9,62 & 6,97 \\
\hline Dyptichandra aurantiaca & 20 & 8 & 0.0637 & 4,93 & 9,39 & 4,44 & 7,16 & 6,25 \\
\hline Pouteria ramiflora & 11 & 7 & 0.0460 & 2,71 & 6,79 & 3,89 & 4,75 & 4,46 \\
\hline Aspidosperma tomentosum & 15 & 6 & 0.0352 & 3,69 & 5,20 & 3,33 & 4,45 & 4,07 \\
\hline Pterodon pubescens & 19 & 7 & 0.0239 & 4,68 & 3,52 & 3,89 & 4,10 & 4,03 \\
\hline Copaifera langsdorfii & 13 & 7 & 0.0333 & 3,20 & 4,92 & 3,89 & 4,06 & 4,00 \\
\hline Vochysia cinamommea & 13 & 3 & 0.0200 & 3,20 & 2,95 & 1,67 & 3,08 & 2,61 \\
\hline Dalbergia miscolobium & 7 & 5 & 0.0217 & 1,72 & 3,20 & 2,78 & 2,46 & 2,57 \\
\hline Miconia albicans & 9 & 4 & 0.0164 & 2,22 & 2,42 & 2,22 & 2,32 & 2,29 \\
\hline Roupala montana & 11 & 5 & 0.0050 & 2,71 & 0,74 & 2,78 & 1,73 & 2,08 \\
\hline Miconia rubiginosa & 9 & 4 & 0.0082 & 2,22 & 1,21 & 2,22 & 1,72 & 1,88 \\
\hline Pouteria torta & 5 & 3 & 0.0183 & 1,23 & 2,70 & 1,67 & 1,97 & 1,87 \\
\hline Strychnos bicolor & 12 & 3 & 0.0057 & 2,96 & 0,84 & 1,67 & 1,90 & 1,82 \\
\hline Anadenanthera falcata & 5 & 4 & 0.0129 & 1,23 & 1,91 & 2,22 & 1,57 & 1,79 \\
\hline Banisteriopsis variabilis & 7 & 2 & 0.0106 & 1,72 & 1,57 & 1,11 & 1,65 & 1,47 \\
\hline Didymopanax vinosum & 4 & 4 & 0.0043 & 0,99 & 0,63 & 2,22 & 0,81 & 1,28 \\
\hline Amaioua guianensis & 6 & 1 & 0.0120 & 1,48 & 1,77 & 0,56 & 1,63 & 1,27 \\
\hline Eugenia punicifolia & 5 & 4 & 0.0019 & 1,23 & 0,28 & 2,22 & 0,76 & 1,24 \\
\hline Annona coriacea & 4 & 4 & 0.0028 & 0,99 & 0,42 & 2,22 & 0,71 & 1,21 \\
\hline Vatairea macrocarpa & 5 & 2 & 0.0078 & 1,23 & 1,15 & 1,11 & 1,19 & 1,16 \\
\hline Connarus suberosus & 4 & 3 & 0.0055 & 0,99 & 0,81 & 1,67 & 0,90 & 1,15 \\
\hline Myrcia lasiantha & 4 & 4 & 0.0015 & 0,99 & 0,22 & 2,22 & 0,61 & 1,14 \\
\hline Banisteriopsis pubipetala & 5 & 3 & 0.0033 & 1,23 & 0,49 & 1,67 & 0,86 & 1,13 \\
\hline Plathymenia reticulata & 2 & 2 & 0.0117 & 0,49 & 1,72 & 1,11 & 1,11 & 1,11 \\
\hline Distictella mansoana & 5 & 3 & 0.0028 & 1,23 & 0,41 & 1,67 & 0,82 & 1,10 \\
\hline Alibertia macrophylla & 7 & 2 & 0.0031 & 1,72 & 0,45 & 1,11 & 1,09 & 1,10 \\
\hline Hymenaea stigonocarpa & 2 & 2 & 0.0108 & 0,49 & 1,60 & 1,11 & 1,05 & 1,07 \\
\hline Syagrus loefgrenii & 4 & 3 & 0.0019 & 0,99 & 0,28 & 1,67 & 0,64 & 0,98 \\
\hline Qualea parviflora & 3 & 2 & 0.0055 & 0,74 & 0,81 & 1,11 & 0,78 & 0,89 \\
\hline Ouratea spectabilis & 3 & 3 & 0.0015 & 0,74 & 0,22 & 1,67 & 0,48 & 0,88 \\
\hline Machaerium acutifolium & 2 & 2 & 0.0069 & 0,49 & 1,01 & 1,11 & 0,75 & 0,87 \\
\hline Siparuna guianensis & 3 & 2 & 0.0039 & 0,74 & 0,58 & 1,11 & 0,66 & 0,81 \\
\hline Bowdichia virgilioides & 2 & 2 & 0.0047 & 0,49 & 0,69 & 1,11 & 0,59 & 0,77 \\
\hline Miconia stenostachya & 3 & 2 & 0.0006 & 0,74 & 0,09 & 1,11 & 0,42 & 0,65 \\
\hline Palicourea rigida & 2 & 2 & 0.0020 & 0,49 & 0,29 & 1,11 & 0,39 & 0,63 \\
\hline Qualea grandiflora & 2 & 2 & 0.0019 & 0,49 & 0,27 & 1,11 & 0,38 & 0,63 \\
\hline Kielmeyera rubriflora & 1 & 1 & 0.0067 & 0,25 & 0,99 & 0,56 & 0,62 & 0,60 \\
\hline Gochnatia pulchra & 2 & 2 & 0.0010 & 0,49 & 0,15 & 1,11 & 0,32 & 0,58 \\
\hline Myrcia uberavensis & 1 & 1 & 0.0062 & 0,25 & 0,92 & 0,56 & 0,59 & 0,57 \\
\hline
\end{tabular}




\begin{tabular}{lllllllll} 
Guapira noxia & 2 & 2 & 0.0007 & 0,49 & 0,10 & 1,11 & 0,30 & 0,57 \\
Banisteriopsis stellaris & 2 & 2 & 0.0004 & 0,49 & 0,06 & 1,11 & 0,28 & 0,55 \\
Duguetia furfuracea & 2 & 2 & 0.0001 & 0,49 & 0,01 & 1,11 & 0,25 & 0,54 \\
Protium heptaphyllum & 2 & 2 & 0.0000 & 0,49 & 0,00 & 1,11 & 0,25 & 0,53 \\
Couepia grandiflora & 1 & 1 & 0.0050 & 0,25 & 0,73 & 0,56 & 0,49 & 0,51 \\
Tabebuia ochracea & 2 & 1 & 0.0025 & 0,49 & 0,38 & 0,56 & 0,44 & 0,47 \\
Qualea multiflora & 3 & 1 & 0.0008 & 0,74 & 0,12 & 0,56 & 0,43 & 0,47 \\
Erythroxylum cuneifolium & 3 & 1 & 0.0004 & 0,74 & 0,07 & 0,56 & 0,41 & 0,45 \\
Serjania reticulata & 1 & 1 & 0.0029 & 0,25 & 0,43 & 0,56 & 0,34 & 0,41 \\
Diospyros hispida & 1 & 1 & 0.0026 & 0,25 & 0,38 & 0,56 & 0,32 & 0,39 \\
Ocotea corymbosa & 2 & 1 & 0.0006 & 0,49 & 0,09 & 0,56 & 0,29 & 0,38 \\
Syagrus flexuosa & 1 & 1 & 0.0023 & 0,25 & 0,33 & 0,56 & 0,29 & 0,38 \\
Neea theifera & 2 & 1 & 0.0003 & 0,49 & 0,05 & 0,56 & 0,27 & 0,36 \\
Casearia grandiflora & 1 & 1 & 0.0010 & 0,25 & 0,14 & 0,56 & 0,20 & 0,31 \\
Jacaranda caroba & 1 & 1 & 0.0005 & 0,25 & 0,08 & 0,56 & 0,17 & 0,29 \\
Sclerolobium paniculatum & 1 & 1 & 0.0005 & 0,25 & 0,08 & 0,56 & 0,17 & 0,29 \\
Erythroxylum campestre & 1 & 1 & 0.0004 & 0,25 & 0,06 & 0,56 & 0,16 & 0,29 \\
Elephantopus biflora & 1 & 1 & 0.0003 & 0,25 & 0,04 & 0,56 & 0,15 & 0,28 \\
Bauhinia rufa & 1 & 1 & 0.0002 & 0,25 & 0,03 & 0,56 & 0,14 & 0,28 \\
Eupatorium maximiliani & 1 & 1 & 0.0002 & 0,25 & 0,03 & 0,56 & 0,14 & 0,28 \\
Periandra mediterranea & 1 & 1 & 0.0002 & 0,25 & 0,02 & 0,56 & 0,14 & 0,27 \\
Pouteria subcaerulea & 1 & 1 & 0.0002 & 0,25 & 0,02 & 0,56 & 0,14 & 0,27 \\
Alibertia sessilis & 1 & 1 & 0.0001 & 0,25 & 0,02 & 0,56 & 0,14 & 0,27 \\
Eugenia livida & 1 & 1 & 0.0001 & 0,25 & 0,02 & 0,56 & 0,14 & 0,27 \\
Parinari excelsa & 1 & 1 & 0.0000 & 0,25 & 0,00 & 0,56 & 0,13 & 0,27 \\
Talisia angustifolia & 1 & 1 & 0.0000 & 0,25 & 0,00 & 0,56 & 0,13 & 0,27 \\
Acosmium dasycarpum & 1 & 1 & 0.0000 & 0,25 & 0,00 & 0,56 & 0,13 & 0,27 \\
Rourea induta & 1 & 1 & 0.0000 & 0,25 & 0,00 & 0,56 & 0,13 & 0,27 \\
Serjania erecta & 1 & 1 & 0.0000 & 0,25 & 0,00 & 0,56 & 0,13 & 0,27 \\
\hline
\end{tabular}

Tabela 4.3 - Parâmetros fitossociológicos dos indivíduos das espécies lenhosas com diâmetro basal inferior até 0,9cm e não-lenhosas em cerradão na ARIE Cerrado Pé-de-Gigante, Santa Rita do Passa Quatro, São Paulo (21³6-44'S e 47 ๑34-41’W), ordenados segundo o valor de importância. Legenda: no. ind. - número de indivíduos; Oc - ocorrência; $\mathrm{AB}=$ área basal $\left(\mathrm{m}^{2}\right) ; \mathrm{DR}$ - densidade relativa (\%); DoR - dominância relativa (\%); FR - freqüência relativa (\%); VC = valor de cobertura (\%); VI - valor de importância $(\%)$.

\begin{tabular}{lcccccccc}
\hline \multicolumn{1}{c}{ espécie } & no. ind. & Oc & AB & DR & DoR & FR & VC & VI \\
\hline \hline Rhynchospora exaltata & 27 & 6 & 0,0161 & 8,97 & 68,20 & 5,17 & 38,59 & 27,45 \\
Myrcia lingua & 36 & 6 & 0,0004 & 11,96 & 1,56 & 5,17 & 6,76 & 6,23 \\
Loudetiopsis chrysothrix & 6 & 1 & 0,0032 & 1,99 & 13,73 & 0,86 & 7,86 & 5,53 \\
Styrax ferrugineus & 28 & 5 & 0,0002 & 9,30 & 0,89 & 4,31 & 5,10 & 4,83 \\
Memora peregrine & 23 & 4 & 0,0002 & 7,64 & 0,67 & 3,45 & 4,16 & 3,92 \\
Copaifera langsdorfii & 23 & 1 & 0,0000 & 7,64 & 0,21 & 0,86 & 3,93 & 2,90 \\
Echinolaena inflexa & 10 & 3 & 0,0006 & 3,32 & 2,58 & 2,59 & 2,95 & 2,83 \\
Banisteriopsis stellaris & 9 & 5 & 0,0000 & 2,99 & 0,11 & 4,31 & 1,55 & 2,47 \\
Dyptichandra aurantiaca & 11 & 4 & 0,0001 & 3,65 & 0,24 & 3,45 & 1,95 & 2,45 \\
Strychnos bicolor & 7 & 4 & 0,0002 & 2,33 & 0,71 & 3,45 & 1,52 & 2,16 \\
Digitaria insularis & 2 & 1 & 0,0010 & 0,66 & 4,20 & 0,86 & 2,43 & 1,91 \\
Rourea induta & 9 & 2 & 0,0001 & 2,99 & 0,49 & 1,72 & 1,74 & 1,73 \\
Miconia albicans & 4 & 3 & 0,0000 & 1,33 & 0,21 & 2,59 & 0,77 & 1,37 \\
Banisteriopsis variabilis & 4 & 3 & 0,0000 & 1,33 & 0,05 & 2,59 & 0,69 & 1,32
\end{tabular}




\begin{tabular}{|c|c|c|c|c|c|c|c|c|}
\hline Xylopia aromatica & 3 & 3 & 0,0000 & 1,00 & 0,17 & 2,59 & 0,59 & 1,25 \\
\hline Myrcia lasiantha & 3 & 3 & 0,0000 & 1,00 & 0,04 & 2,59 & 0,52 & 1,21 \\
\hline Licania humilis & 3 & 3 & 0,0000 & 1,00 & 0,03 & 2,59 & 0,52 & 1,20 \\
\hline Ocotea corymbosa & 8 & 1 & 0,0000 & 2,66 & 0,06 & 0,86 & 1,36 & 1,19 \\
\hline Guapira noxia & 4 & 2 & 0,0000 & 1,33 & 0,20 & 1,72 & 0,77 & 1,08 \\
\hline Qualea multiflora & 3 & 2 & 0,0001 & 1,00 & 0,48 & 1,72 & 0,74 & 1,07 \\
\hline Diodia schumanii & 4 & 2 & 0,0000 & 1,33 & 0,08 & 1,72 & 0,71 & 1,05 \\
\hline Melinis minutiflora & 3 & 1 & 0,0003 & 1,00 & 1,06 & 0,86 & 1,03 & 0,97 \\
\hline Gochnatia pulchra & 5 & 1 & 0,0001 & 1,66 & 0,39 & 0,86 & 1,03 & 0,97 \\
\hline Ichnanthus sericeus & 3 & 2 & 0,0000 & 1,00 & 0,06 & 1,72 & 0,53 & 0,93 \\
\hline Ouratea spectabilis & 3 & 2 & 0,0000 & 1,00 & 0,04 & 1,72 & 0,52 & 0,92 \\
\hline Connarus suberosus & 3 & 2 & 0,0000 & 1,00 & 0,04 & 1,72 & 0,52 & 0,92 \\
\hline Smilax cissoides & 3 & 2 & 0,0000 & 1,00 & 0,02 & 1,72 & 0,51 & 0,91 \\
\hline Anacardium humile & 2 & 2 & 0,0001 & 0,66 & 0,22 & 1,72 & 0,44 & 0,87 \\
\hline Scleria comosa & 2 & 2 & 0,0000 & 0,66 & 0,16 & 1,72 & 0,41 & 0,85 \\
\hline Qualea grandiflora & 2 & 2 & 0,0000 & 0,66 & 0,08 & 1,72 & 0,37 & 0,82 \\
\hline Casearia sylvestris & 2 & 2 & 0,0000 & 0,66 & 0,02 & 1,72 & 0,34 & 0,80 \\
\hline Alternanthera brasiliana & 4 & 1 & 0,0000 & 1,33 & 0,17 & 0,86 & 0,75 & 0,79 \\
\hline Roupala montana & 3 & 1 & 0,0001 & 1,00 & 0,35 & 0,86 & 0,68 & 0,74 \\
\hline Commelina erecta & 3 & 1 & 0,0000 & 1,00 & 0,15 & 0,86 & 0,58 & 0,67 \\
\hline Syagrus loefgrenii & 2 & 1 & 0,0001 & 0,66 & 0,32 & 0,86 & 0,49 & 0,62 \\
\hline Virola sebifera & 2 & 1 & 0,0001 & 0,66 & 0,22 & 0,86 & 0,44 & 0,58 \\
\hline Plathymenia reticulata & 2 & 1 & 0,0000 & 0,66 & 0,17 & 0,86 & 0,42 & 0,57 \\
\hline Panicum maximum & 2 & 1 & 0,0000 & 0,66 & 0,08 & 0,86 & 0,37 & 0,54 \\
\hline Dasyphyllum sprengelianum & 2 & 1 & 0,0000 & 0,66 & 0,04 & 0,86 & 0,35 & 0,52 \\
\hline Diospyros hispida & 1 & 1 & 0,0001 & 0,33 & 0,27 & 0,86 & 0,30 & 0,49 \\
\hline Pradosia brevipes & 1 & 1 & 0,0001 & 0,33 & 0,26 & 0,86 & 0,30 & 0,49 \\
\hline Bauhinia rufa & 1 & 1 & 0,0001 & 0,33 & 0,21 & 0,86 & 0,27 & 0,47 \\
\hline Vatairea macrocarpa & 1 & 1 & 0,0000 & 0,33 & 0,20 & 0,86 & 0,27 & 0,46 \\
\hline Periandra mediterranea & 1 & 1 & 0,0000 & 0,33 & 0,08 & 0,86 & 0,21 & 0,43 \\
\hline Galactia grewiifolia & 1 & 1 & 0,0000 & 0,33 & 0,08 & 0,86 & 0,21 & 0,43 \\
\hline Mascagnia cordifolia & 1 & 1 & 0,0000 & 0,33 & 0,08 & 0,86 & 0,21 & 0,43 \\
\hline Protium heptaphyllum & 1 & 1 & 0,0000 & 0,33 & 0,07 & 0,86 & 0,20 & 0,42 \\
\hline Psychotria barbiflora & 1 & 1 & 0,0000 & 0,33 & 0,03 & 0,86 & 0,18 & 0,41 \\
\hline Myrcia pubipetala & 1 & 1 & 0,0000 & 0,33 & 0,03 & 0,86 & 0,18 & 0,41 \\
\hline Eugenia punicifolia & 1 & 1 & 0,0000 & 0,33 & 0,02 & 0,86 & 0,18 & 0,41 \\
\hline Byttneria sagittifolia & 1 & 1 & 0,0000 & 0,33 & 0,02 & 0,86 & 0,18 & 0,41 \\
\hline Alibertia sessilis & 1 & 1 & 0,0000 & 0,33 & 0,02 & 0,86 & 0,18 & 0,41 \\
\hline Qualea dichotoma & 1 & 1 & 0,0000 & 0,33 & 0,01 & 0,86 & 0,17 & 0,40 \\
\hline Eupatorium maximiliani & 1 & 1 & 0,0000 & 0,33 & 0,01 & 0,86 & 0,17 & 0,40 \\
\hline Pouteria torta & 1 & 1 & 0,0000 & 0,33 & 0,01 & 0,86 & 0,17 & 0,40 \\
\hline Myrcia tomentosa & 1 & 1 & 0,0000 & 0,33 & 0,01 & 0,86 & 0,17 & 0,40 \\
\hline Froelichia lanata & 1 & 1 & 0,0000 & 0,33 & 0,01 & 0,86 & 0,17 & 0,40 \\
\hline Eugenia langsdorfii & 1 & 1 & 0,0000 & 0,33 & 0,01 & 0,86 & 0,17 & 0,40 \\
\hline Lippia salviifolia & 1 & 1 & 0,0000 & 0,33 & 0,01 & 0,86 & 0,17 & 0,40 \\
\hline Pterodon pubescens & 1 & 1 & 0,0000 & 0,33 & 0,00 & 0,86 & 0,17 & 0,40 \\
\hline Lantana camara & 1 & 1 & 0,0000 & 0,33 & 0,00 & 0,86 & 0,17 & 0,40 \\
\hline Serjania reticulata & 1 & 1 & 0,0000 & 0,33 & 0,00 & 0,86 & 0,17 & 0,40 \\
\hline Declieuxia fruticosa & 1 & 1 & 0,0000 & 0,33 & 0,00 & 0,86 & 0,17 & 0,40 \\
\hline Erythroxylum cuneifolium & 1 & 1 & 0,0000 & 0,33 & 0,00 & 0,86 & 0,17 & 0,40 \\
\hline Erythroxylum campestre & 1 & 1 & 0,0000 & 0,33 & 0,00 & 0,86 & 0,17 & 0,40 \\
\hline
\end{tabular}




\section{Cerrado "sensu stricto"}

As espécies amostradas no cerrado "sensu stricto", ordenadas pelo valor de importância (VI), estão reunidas nas Tabelas 4.4 (indivíduos lenhosos com mais de $1 \mathrm{~cm}$ de diâmetro basal) e 4.5 (indivíduos lenhosos com até $0,9 \mathrm{~cm}$ de diâmetro basal e não-lenhosos).

Nas parcelas maiores (Tabela 4.4), foram amostrados 687 indivíduos, representando 84 espécies e 33 famílias. As espécies com maiores valores de importância foram, pela ordem, Myrcia lingua, Xylopia aromatica, Dyptichandra aurantiaca, Miconia albicans e Anadenanthera falcata, que perfizeram 30,22\% do total. Strychnos bicolor, com 35 indivíduos em 3 parcelas, Virola sebifera, com 18 indivíduos em 2 parcelas, e Banisteriopsis variabilis, com 16 indivíduos em 1 parcela, foram as espécies com distribuição mais agregada. Foram representadas por um indivíduo 19 espécies. Myrtaceae, com 9 espécies, e Vochysiaceae e Malpighiaceae, com 6 espécies cada, foram as famílias com maiores riquezas.

Pagano et al. (1989) estudaram a estrutura do componente arbustivo-arbóreo do cerrado na Área de Proteção Ambiental de Corumbataí, onde havia predomínio de cerrado "sensu stricto". Das 15 espécies com maiores valores de importância em Corumbataí, apenas 4 estão entre as 15 mais importantes no componente dominante desta fisionomia na ARIE Pé-de-Gigante, ressaltando a variação regional do cerrado já apontada por aqueles autores (Pagano et al. 1989).

Nas parcelas menores (Tabela 4.5), foram amostrados 399 indivíduos, pertencentes a 81 espécies e 40 famílias. Como no cerradão, a espécie mais importante neste componente foi Rhynchospora exaltata com 30,75\% do VI. Em seguida, apareceram Loudetiopsis chrysothrix, Axonopus marginatus, Byrsonima intermedia e Ichnanthus sericeus, que representaram $15,74 \%$ do total. Comparando-se a ordenação pelo valor de importância com os valores de cobertura, verifica-se uma maior diferença para Digitaria insularis, que apresentou valor de cobertura mais elevado em 
função de sua alta dominância. Entre as dez populações mais abundantes, há espécies do componente dominante, como Rourea induta, Myrcia lingua, Miconia albicans e Styrax ferrugineus, mostrando um potencial regenerante destas populações. Das 81 espécies amostradas, 28 o foram uma única vez. Neste componente, as famílias mais representativas quanto à riqueza em espécies foram Poaceae e Malpighiaceae, cada uma com 6 espécies, e Bignoniaceae, Myrtaceae e Fabaceae, com 5 espécies cada.

Tabela 4.4 - Parâmetros fitossociológicos dos indivíduos das espécies lenhosas com diâmetro basal superior a $1 \mathrm{~cm}$ em cerrado “sensu stricto” na ARIE Cerrado Pé-de-Gigante, Santa Rita do Passa Quatro, São Paulo (2136-44’S e 47 34-41'W), ordenados segundo o valor de importância. Legenda: no. ind. - número de indivíduos; Oc - ocorrência; AB = área basal $\left(\mathrm{m}^{2}\right) ; \mathrm{DR}$ - densidade relativa $(\%)$; DoR - dominância relativa $(\%) ; \mathrm{FR}$ - freqüência relativa $(\%)$; VC = valor de cobertura (\%); VI - valor de importância (\%).

\begin{tabular}{|c|c|c|c|c|c|c|c|c|}
\hline espécie & no. ind. & Oc & $\mathbf{A B}$ & DR & DoR & FR & $\mathbf{V C}$ & VI \\
\hline Myrcia lingua & 94 & 10 & 0,1951 & 13,68 & 9,77 & 3,77 & 11,73 & 9,07 \\
\hline Xylopia aromatica & 55 & 10 & 0,1990 & 8,01 & 9,96 & 3,77 & 8,99 & 7,25 \\
\hline Dyptichandra aurantiaca & 43 & 10 & 0,2198 & 6,26 & 11,01 & 3,77 & 8,64 & 7,01 \\
\hline Miconia albicans & 30 & 8 & 0,0953 & 4,37 & 4,77 & 3,02 & 4,57 & 4,05 \\
\hline Anadenanthera falcata & 9 & 7 & 0,0915 & 1,31 & 4,58 & 2,64 & 2,95 & 2,84 \\
\hline Miconia rubiginosa & 18 & 8 & 0,0569 & 2,62 & 2,85 & 3,02 & 2,74 & 2,83 \\
\hline Myrcia lasiantha & 20 & 9 & 0,0392 & 2,91 & 1,96 & 3,40 & 2,44 & 2,76 \\
\hline Pouteria ramiflora & 17 & 6 & 0,0657 & 2,47 & 3,29 & 2,26 & 2,88 & 2,68 \\
\hline Copaifera langsdorfii & 8 & 5 & 0,0931 & 1,16 & 4,66 & 1,89 & 2,91 & 2,57 \\
\hline Qualea parviflora & 16 & 6 & 0,0598 & 2,33 & 2,99 & 2,26 & 2,66 & 2,53 \\
\hline Ouratea spectabilis & 14 & 6 & 0,0632 & 2,04 & 3,16 & 2,26 & 2,60 & 2,49 \\
\hline Pterodon pubescens & 14 & 4 & 0,0769 & 2,04 & 3,85 & 1,51 & 2,95 & 2,47 \\
\hline Plathymenia reticulata & 10 & 5 & 0,0799 & 1,46 & 4,00 & 1,89 & 2,73 & 2,45 \\
\hline Strychnos bicolor & 35 & 3 & 0,0172 & 5,09 & 0,86 & 1,13 & 2,98 & 2,36 \\
\hline Caryocar brasiliense & 6 & 5 & 0,0771 & 0,87 & 3,86 & 1,89 & 2,37 & 2,21 \\
\hline Vochysia cinamommea & 11 & 4 & 0,0618 & 1,60 & 3,09 & 1,51 & 2,35 & 2,07 \\
\hline Vatairea macrocarpa & 17 & 5 & 0,0317 & 2,47 & 1,59 & 1,89 & 2,03 & 1,98 \\
\hline Syagrus loefgrenii & 18 & 4 & 0,0255 & 2,62 & 1,28 & 1,51 & 1,95 & 1,80 \\
\hline Banisteriopsis pubipetala & 17 & 4 & 0,0221 & 2,47 & 1,11 & 1,51 & 1,79 & 1,70 \\
\hline Didymopanax vinosum & 13 & 5 & 0,0192 & 1,89 & 0,96 & 1,89 & 1,43 & 1,58 \\
\hline Aspidosperma tomentosum & 9 & 6 & 0,0210 & 1,31 & 1,05 & 2,26 & 1,18 & 1,54 \\
\hline Hymenaea stigonocarpa & 2 & 2 & 0,0651 & 0,29 & 3,26 & 0,75 & 1,78 & 1,43 \\
\hline Qualea multiflora & 9 & 6 & 0,0141 & 1,31 & 0,71 & 2,26 & 1,01 & 1,43 \\
\hline Roupala montana & 8 & 5 & 0,0159 & 1,16 & 0,80 & 1,89 & 0,98 & 1,28 \\
\hline Virola sebifera & 18 & 2 & 0,0092 & 2,62 & 0,46 & 0,75 & 1,54 & 1,28 \\
\hline Qualea dichotoma & 6 & 5 & 0,0182 & 0,87 & 0,91 & 1,89 & 0,89 & 1,22 \\
\hline Qualea grandiflora & 5 & 4 & 0,0279 & 0,73 & 1,40 & 1,51 & 1,07 & 1,21 \\
\hline Distictella mansoana & 9 & 3 & 0,0215 & 1,31 & 1,08 & 1,13 & 1,20 & 1,17 \\
\hline Banisteriopsis variabilis & 16 & 1 & 0,0144 & 2,33 & 0,72 & 0,38 & 1,53 & 1,14 \\
\hline Gochnatia pulchra & 6 & 4 & 0,0119 & 0,87 & 0,60 & 1,51 & 0,74 & 0,99 \\
\hline
\end{tabular}




\begin{tabular}{|c|c|c|c|c|c|c|c|c|}
\hline Eugenia bimarginata & 6 & 4 & 0,0071 & 0,87 & 0,36 & 1,51 & 0,62 & 0,91 \\
\hline Tabebuia ochracea & 5 & 4 & 0,0082 & 0,73 & 0,41 & 1,51 & 0,57 & 0,88 \\
\hline Annona coriacea & 5 & 4 & 0,0047 & 0,73 & 0,24 & 1,51 & 0,49 & 0,82 \\
\hline Dalbergia miscolobium & 4 & 3 & 0,0136 & 0,58 & 0,68 & 1,13 & 0,63 & 0,80 \\
\hline Pouteria torta & 5 & 3 & 0,0104 & 0,73 & 0,52 & 1,13 & 0,63 & 0,79 \\
\hline Miconia stenostachya & 4 & 3 & 0,0120 & 0,58 & 0,60 & 1,13 & 0,59 & 0,77 \\
\hline Myrcia bella & 4 & 4 & 0,0035 & 0,58 & 0,17 & 1,51 & 0,38 & 0,75 \\
\hline Bauhinia rufa & 4 & 4 & 0,0028 & 0,58 & 0,14 & 1,51 & 0,36 & 0,74 \\
\hline Memora peregrine & 4 & 4 & 0,0006 & 0,58 & 0,03 & 1,51 & 0,31 & 0,71 \\
\hline Byrsonima intermedia & 6 & 3 & 0,0011 & 0,87 & 0,06 & 1,13 & 0,47 & 0,69 \\
\hline Eugenia aurata & 3 & 3 & 0,0082 & 0,44 & 0,41 & 1,13 & 0,43 & 0,66 \\
\hline Duguetia furfuracea & 5 & 3 & 0,0020 & 0,73 & 0,10 & 1,13 & 0,42 & 0,65 \\
\hline Erythroxylum suberosum & 5 & 2 & 0,0087 & 0,73 & 0,44 & 0,75 & 0,59 & 0,64 \\
\hline Palicourea rigida & 4 & 3 & 0,0033 & 0,58 & 0,16 & 1,13 & 0,37 & 0,63 \\
\hline Psidium australe & 4 & 3 & 0,0015 & 0,58 & 0,08 & 1,13 & 0,33 & 0,60 \\
\hline Stryphnodendron polyphyllum & 2 & 2 & 0,0112 & 0,29 & 0,56 & 0,75 & 0,43 & 0,54 \\
\hline Styrax ferrugineus & 3 & 2 & 0,0075 & 0,44 & 0,38 & 0,75 & 0,41 & 0,52 \\
\hline Kielmeyera rubriflora & 2 & 2 & 0,0087 & 0,29 & 0,43 & 0,75 & 0,36 & 0,49 \\
\hline Connarus suberosus & 3 & 2 & 0,0057 & 0,44 & 0,28 & 0,75 & 0,36 & 0,49 \\
\hline Bowdichia virgilioides & 2 & 2 & 0,0084 & 0,29 & 0,42 & 0,75 & 0,36 & 0,49 \\
\hline Couepia grandiflora & 3 & 2 & 0,0027 & 0,44 & 0,14 & 0,75 & 0,29 & 0,44 \\
\hline Andira laurifolia & 3 & 2 & 0,0004 & 0,44 & 0,02 & 0,75 & 0,23 & 0,40 \\
\hline Leandra lacunosa & 2 & 2 & 0,0030 & 0,29 & 0,15 & 0,75 & 0,22 & 0,40 \\
\hline Byrsonima coccolobifolia & 2 & 2 & 0,0024 & 0,29 & 0,12 & 0,75 & 0,21 & 0,39 \\
\hline Guapira noxia & 2 & 2 & 0,0022 & 0,29 & 0,11 & 0,75 & 0,20 & 0,39 \\
\hline Vanillosmopsis erythropappa & 2 & 1 & 0,0096 & 0,29 & 0,48 & 0,38 & 0,39 & 0,38 \\
\hline Dimorphandra mollis & 2 & 2 & 0,0015 & 0,29 & 0,07 & 0,75 & 0,18 & 0,37 \\
\hline Banisteriopsis stellaris & 2 & 2 & 0,0011 & 0,29 & 0,06 & 0,75 & 0,18 & 0,37 \\
\hline Tocoyena formosa & 2 & 2 & 0,0011 & 0,29 & 0,05 & 0,75 & 0,17 & 0,37 \\
\hline Rourea induta & 2 & 2 & 0,0004 & 0,29 & 0,02 & 0,75 & 0,16 & 0,36 \\
\hline Toulicia tomentosa & 4 & 1 & 0,0010 & 0,58 & 0,05 & 0,38 & 0,32 & 0,34 \\
\hline Syagrus flexиosa & 2 & 1 & 0,0067 & 0,29 & 0,34 & 0,38 & 0,32 & 0,34 \\
\hline Heteropteris byrsonimifolia & 3 & 1 & 0,0012 & 0,44 & 0,06 & 0,38 & 0,25 & 0,29 \\
\hline Lafoensia pacari & 1 & 1 & 0,0062 & 0,15 & 0,31 & 0,38 & 0,23 & 0,28 \\
\hline Neea theifera & 2 & 1 & 0,0008 & 0,29 & 0,04 & 0,38 & 0,17 & 0,24 \\
\hline Diospyros hispida & 2 & 1 & 0,0004 & 0,29 & 0,02 & 0,38 & 0,16 & 0,23 \\
\hline Erythroxylum campestre & 1 & 1 & 0,0029 & 0,15 & 0,14 & 0,38 & 0,15 & 0,22 \\
\hline Eugenia punicifolia & 1 & 1 & 0,0023 & 0,15 & 0,12 & 0,38 & 0,14 & 0,21 \\
\hline Eugenia livida & 1 & 1 & 0,0018 & 0,15 & 0,09 & 0,38 & 0,12 & 0,20 \\
\hline Stryphnodendron adstringens & 1 & 1 & 0,0018 & 0,15 & 0,09 & 0,38 & 0,12 & 0,20 \\
\hline Erythroxylum tortuosum & 1 & 1 & 0,0013 & 0,15 & 0,07 & 0,38 & 0,11 & 0,20 \\
\hline Piptocarpha rotundifolia & 1 & 1 & 0,0013 & 0,15 & 0,07 & 0,38 & 0,11 & 0,20 \\
\hline Licania humilis & 1 & 1 & 0,0011 & 0,15 & 0,06 & 0,38 & 0,11 & 0,19 \\
\hline Protium heptaphyllum & 1 & 1 & 0,0010 & 0,15 & 0,05 & 0,38 & 0,10 & 0,19 \\
\hline Cybistax antisyphillitica & 1 & 1 & 0,0010 & 0,15 & 0,05 & 0,38 & 0,10 & 0,19 \\
\hline Casearia sylvestris & 1 & 1 & 0,0008 & 0,15 & 0,04 & 0,38 & 0,10 & 0,19 \\
\hline Davilla rugosa & 1 & 1 & 0,0007 & 0,15 & 0,03 & 0,38 & 0,09 & 0,19 \\
\hline Campomanesia pubescens & 1 & 1 & 0,0004 & 0,15 & 0,02 & 0,38 & 0,09 & 0,18 \\
\hline Miconia ligustroides & 1 & 1 & 0,0004 & 0,15 & 0,02 & 0,38 & 0,09 & 0,18 \\
\hline Vochysia tucanorum & 1 & 1 & 0,0004 & 0,15 & 0,02 & 0,38 & 0,09 & 0,18 \\
\hline Senna rugosa & 1 & 1 & 0,0003 & 0,15 & 0,02 & 0,38 & 0,09 & 0,18 \\
\hline Arrabidaea brachypoda & 1 & 1 & 0,0002 & 0,15 & 0,01 & 0,38 & 0,08 & 0,18 \\
\hline Parinari excelsa & 1 & 1 & 0,0001 & 0,15 & 0,01 & 0,38 & 0,08 & 0,18 \\
\hline
\end{tabular}


Tabela 4.5 - Parâmetros fitossociológicos dos indivíduos das espécies lenhosas com diâmetro basal até $0,9 \mathrm{~cm}$ e nãolenhosas em cerrado "sensu stricto” na ARIE Cerrado Pé-de-Gigante, Santa Rita do Passa Quatro, São Paulo (21³644'S e 47³4-41'W), ordenados segundo o valor de importância. Legenda: no. ind. - número de indivíduos; Oc ocorrência; $\mathrm{AB}=$ área basal $\left(\mathrm{m}^{2}\right)$; DR - densidade relativa $(\%)$; DoR - dominância relativa $(\%)$; FR - freqüência relativa (\%); VC = valor de cobertura (\%); VI - valor de importância (\%).

\begin{tabular}{|c|c|c|c|c|c|c|c|c|}
\hline espécie & no. ind. & Oc & $\mathbf{A B}$ & DR & DoR & FR & VC & VI \\
\hline Rhynchospora exaltata & 81 & 10 & 0,0862 & 20,30 & 66,24 & 5,71 & 43,27 & 30,75 \\
\hline Loudetiopsis chrysothrix & 12 & 5 & 0,0104 & 3,01 & 8,03 & 2,86 & 5,52 & 4,63 \\
\hline Axonopus marginatus & 7 & 2 & 0,0122 & 1,75 & 9,39 & 1,14 & 5,57 & 4,09 \\
\hline Byrsonima intermedia & 29 & 6 & 0,0005 & 7,27 & 0,41 & 3,43 & 3,84 & 3,70 \\
\hline Ichnanthus sericeus & 19 & 5 & 0,0030 & 4,76 & 2,34 & 2,86 & 3,55 & 3,32 \\
\hline Digitaria insularis & 2 & 2 & 0,0106 & 0,50 & 8,13 & 1,14 & 4,32 & 3,26 \\
\hline Rourea induta & 23 & 6 & 0,0002 & 5,76 & 0,12 & 3,43 & 2,94 & 3,11 \\
\hline Myrcia lingua & 16 & 8 & 0,0001 & 4,01 & 0,05 & 4,57 & 2,03 & 2,88 \\
\hline Memora peregrine & 17 & 7 & 0,0003 & 4,26 & 0,24 & 4,00 & 2,25 & 2,83 \\
\hline Miconia albicans & 14 & 6 & 0,0003 & 3,51 & 0,26 & 3,43 & 1,89 & 2,40 \\
\hline Styrax ferrugineus & 11 & 5 & 0,0001 & 2,76 & 0,08 & 2,86 & 1,42 & 1,90 \\
\hline Smilax cissoides & 10 & 5 & 0,0002 & 2,51 & 0,16 & 2,86 & 1,34 & 1,84 \\
\hline Gochnatia pulchra & 10 & 5 & 0,0001 & 2,51 & 0,04 & 2,86 & 1,28 & 1,80 \\
\hline Banisteriopsis stellaris & 9 & 5 & 0,0000 & 2,26 & 0,03 & 2,86 & 1,15 & 1,72 \\
\hline Ouratea spectabilis & 6 & 4 & 0,0001 & 1,50 & 0,05 & 2,29 & 0,78 & 1,28 \\
\hline Myrcia lasiantha & 6 & 4 & 0,0000 & 1,50 & 0,03 & 2,29 & 0,77 & 1,27 \\
\hline Tristachya leiostachya & 1 & 1 & 0,0024 & 0,25 & 1,83 & 0,57 & 1,04 & 0,88 \\
\hline Andira laurifolia & 3 & 3 & 0,0001 & 0,75 & 0,08 & 1,71 & 0,42 & 0,85 \\
\hline Copaifera langsdorfii & 3 & 3 & 0,0001 & 0,75 & 0,06 & 1,71 & 0,41 & 0,84 \\
\hline Pterodon pubescens & 5 & 2 & 0,0001 & 1,25 & 0,07 & 1,14 & 0,66 & 0,82 \\
\hline Lippia salviifolia & 5 & 2 & 0,0000 & 1,25 & 0,01 & 1,14 & 0,63 & 0,80 \\
\hline Licania humilis & 4 & 2 & 0,0000 & 1,00 & 0,01 & 1,14 & 0,51 & 0,72 \\
\hline Hyptis reticulata & 4 & 2 & 0,0000 & 1,00 & 0,00 & 1,14 & 0,50 & 0,72 \\
\hline Ananas ananassoides & 2 & 2 & 0,0006 & 0,50 & 0,48 & 1,14 & 0,49 & 0,71 \\
\hline Eugenia bimarginata & 6 & 1 & 0,0000 & 1,50 & 0,01 & 0,57 & 0,76 & 0,69 \\
\hline Peltodon tomentosus & 3 & 2 & 0,0001 & 0,75 & 0,06 & 1,14 & 0,41 & 0,65 \\
\hline Leandra lacunosa & 3 & 2 & 0,0000 & 0,75 & 0,04 & 1,14 & 0,40 & 0,64 \\
\hline Echinolaena inflexa & 3 & 2 & 0,0000 & 0,75 & 0,03 & 1,14 & 0,39 & 0,64 \\
\hline Ocotea corymbosa & 3 & 2 & 0,0000 & 0,75 & 0,02 & 1,14 & 0,39 & 0,64 \\
\hline Connarus suberosus & 3 & 2 & 0,0000 & 0,75 & 0,01 & 1,14 & 0,38 & 0,64 \\
\hline Cissampelos ovalifolia & 3 & 2 & 0,0000 & 0,75 & 0,00 & 1,14 & 0,38 & 0,63 \\
\hline Scleria comosa & 2 & 1 & 0,0010 & 0,50 & 0,77 & 0,57 & 0,64 & 0,61 \\
\hline Cyperus diffusus & 2 & 2 & 0,0002 & 0,50 & 0,17 & 1,14 & 0,34 & 0,61 \\
\hline Couepia grandiflora & 2 & 2 & 0,0001 & 0,50 & 0,06 & 1,14 & 0,28 & 0,57 \\
\hline Pradosia brevipes & 2 & 2 & 0,0001 & 0,50 & 0,05 & 1,14 & 0,28 & 0,57 \\
\hline Qualea multiflora & 2 & 2 & 0,0001 & 0,50 & 0,05 & 1,14 & 0,28 & 0,56 \\
\hline Jacaranda caroba & 2 & 2 & 0,0000 & 0,50 & 0,01 & 1,14 & 0,26 & 0,55 \\
\hline Xylopia aromatica & 2 & 2 & 0,0000 & 0,50 & 0,01 & 1,14 & 0,26 & 0,55 \\
\hline Miconia rubiginosa & 2 & 2 & 0,0000 & 0,50 & 0,01 & 1,14 & 0,26 & 0,55 \\
\hline Byrsonima coccolobifolia & 2 & 2 & 0,0000 & 0,50 & 0,01 & 1,14 & 0,26 & 0,55 \\
\hline Machaerium acutifolium & 2 & 2 & 0,0000 & 0,50 & 0,01 & 1,14 & 0,26 & 0,55 \\
\hline
\end{tabular}




\begin{tabular}{|c|c|c|c|c|c|c|c|c|}
\hline Banisteriopsis variabilis & 2 & 2 & 0,0000 & 0,50 & 0,01 & 1,14 & 0,26 & 0,55 \\
\hline Tabebuia ochracea & 3 & 1 & 0,0000 & 0,75 & 0,03 & 0,57 & 0,39 & 0,45 \\
\hline Stryphnodendron polyphyllum & 3 & 1 & 0,0000 & 0,75 & 0,02 & 0,57 & 0,39 & 0,45 \\
\hline Roupala montana & 3 & 1 & 0,0000 & 0,75 & 0,01 & 0,57 & 0,38 & 0,45 \\
\hline Miconia ligustroides & 2 & 1 & 0,0000 & 0,50 & 0,03 & 0,57 & 0,27 & 0,37 \\
\hline Toulicia tomentosa & 2 & 1 & 0,0000 & 0,50 & 0,03 & 0,57 & 0,27 & 0,37 \\
\hline Pouteria torta & 2 & 1 & 0,0000 & 0,50 & 0,02 & 0,57 & 0,26 & 0,37 \\
\hline Strychnos bicolor & 2 & 1 & 0,0000 & 0,50 & 0,02 & 0,57 & 0,26 & 0,36 \\
\hline Casearia sylvestris & 2 & 1 & 0,0000 & 0,50 & 0,01 & 0,57 & 0,26 & 0,36 \\
\hline Manihot tripartita & 2 & 1 & 0,0000 & 0,50 & 0,00 & 0,57 & 0,25 & 0,36 \\
\hline Vanillosmopsis erythropappa & 2 & 1 & 0,0000 & 0,50 & 0,00 & 0,57 & 0,25 & 0,36 \\
\hline Banisteriopsis pubipetala & 2 & 1 & 0,0000 & 0,50 & 0,00 & 0,57 & 0,25 & 0,36 \\
\hline Ruellia geminiflora & 2 & 1 & 0,0000 & 0,50 & 0,00 & 0,57 & 0,25 & 0,36 \\
\hline Syagrus flexuosa & 1 & 1 & 0,0001 & 0,25 & 0,09 & 0,57 & 0,17 & 0,30 \\
\hline Psidium australe & 1 & 1 & 0,0001 & 0,25 & 0,04 & 0,57 & 0,15 & 0,29 \\
\hline Aspidosperma tomentosum & 1 & 1 & 0,0000 & 0,25 & 0,03 & 0,57 & 0,14 & 0,28 \\
\hline Commelina erecta & 1 & 1 & 0,0000 & 0,25 & 0,03 & 0,57 & 0,14 & 0,28 \\
\hline Cybistax antisyphillitica & 1 & 1 & 0,0000 & 0,25 & 0,03 & 0,57 & 0,14 & 0,28 \\
\hline Banisteriopsis campestris & 1 & 1 & 0,0000 & 0,25 & 0,02 & 0,57 & 0,14 & 0,28 \\
\hline Anacardium humile & 1 & 1 & 0,0000 & 0,25 & 0,02 & 0,57 & 0,14 & 0,28 \\
\hline Lafoensia pacari & 1 & 1 & 0,0000 & 0,25 & 0,01 & 0,57 & 0,13 & 0,28 \\
\hline Neea theifera & 1 & 1 & 0,0000 & 0,25 & 0,01 & 0,57 & 0,13 & 0,28 \\
\hline Froelichia lanata & 1 & 1 & 0,0000 & 0,25 & 0,01 & 0,57 & 0,13 & 0,28 \\
\hline Duguetia furfuracea & 1 & 1 & 0,0000 & 0,25 & 0,01 & 0,57 & 0,13 & 0,28 \\
\hline Didymopanax vinosum & 1 & 1 & 0,0000 & 0,25 & 0,01 & 0,57 & 0,13 & 0,28 \\
\hline Jacaranda rufa & 1 & 1 & 0,0000 & 0,25 & 0,01 & 0,57 & 0,13 & 0,28 \\
\hline Parinari excelsa & 1 & 1 & 0,0000 & 0,25 & 0,01 & 0,57 & 0,13 & 0,28 \\
\hline Alternanthera brasiliana & 1 & 1 & 0,0000 & 0,25 & 0,01 & 0,57 & 0,13 & 0,28 \\
\hline Diospyros hispida & 1 & 1 & 0,0000 & 0,25 & 0,01 & 0,57 & 0,13 & 0,28 \\
\hline Qualea dichotoma & 1 & 1 & 0,0000 & 0,25 & 0,01 & 0,57 & 0,13 & 0,28 \\
\hline Virola sebifera & 1 & 1 & 0,0000 & 0,25 & 0,00 & 0,57 & 0,13 & 0,27 \\
\hline Vatairea macrocarpa & 1 & 1 & 0,0000 & 0,25 & 0,00 & 0,57 & 0,13 & 0,27 \\
\hline Palicourea coriacea & 1 & 1 & 0,0000 & 0,25 & 0,00 & 0,57 & 0,13 & 0,27 \\
\hline Declieuxia fruticosa & 1 & 1 & 0,0000 & 0,25 & 0,00 & 0,57 & 0,13 & 0,27 \\
\hline Serjania reticulata & 1 & 1 & 0,0000 & 0,25 & 0,00 & 0,57 & 0,13 & 0,27 \\
\hline Casearia grandiflora & 1 & 1 & 0,0000 & 0,25 & 0,00 & 0,57 & 0,13 & 0,27 \\
\hline Eriosema crinitum & 1 & 1 & 0,0000 & 0,25 & 0,00 & 0,57 & 0,13 & 0,27 \\
\hline Myrcia bella & 1 & 1 & 0,0000 & 0,25 & 0,00 & 0,57 & 0,13 & 0,27 \\
\hline Eupatorium squalidum & 1 & 1 & 0,0000 & 0,25 & 0,00 & 0,57 & 0,13 & 0,27 \\
\hline Zeyhera montana & 1 & 1 & 0,0000 & 0,25 & 0,00 & 0,57 & 0,13 & 0,27 \\
\hline
\end{tabular}

\section{Campo cerrado}

As espécies amostradas no campo cerrado, ordenadas pelo valor de importância (VI), estão reunidas nas Tabelas 4.6 (indivíduos lenhosos com mais de 1cm de diâmetro basal) e 4.7 (indivíduos 
lenhosos com até $0,9 \mathrm{~cm}$ de diâmetro basal e não-lenhosos).

Nas parcelas maiores (Tabela 4.6), foram amostrados 621 indivíduos, compreendendo 87 espécies e 36 famílias. As espécies mais importantes foram, pela ordem, Pouteria torta, Anadenanthera falcata, Miconia albicans, Byrsonima intermedia e Ouratea spectabilis, que representaram 33,93\% do total. Há algumas inversões na ordenação das populações quanto ao valor de importância e ao valor de cobertura. Amostraram-se 42 indivíduos em 2 parcelas de Miconia albicans, o que indicou agregração em sua distribuição, consequiência, provavelmente, de reprodução vegetativa. Tabebuia ochracea teve valor de cobertura menor que o de importância devido à sua baixa dominância relativa. Embora sua frequiência seja baixa, Talisia angustifolia apresentou alta dominância por ser uma espécie sobolífera, com grande área ocupada por seus diversos sóboles. Foram representadas por um indivíduo 28 das 87 espécies encontradas. As famílias mais ricas em espécies, neste componente, foram Myrtaceae (9), Malpighiaceae (8), Asteraceae (7) e Melastomataceae (6).

Das 15 espécies arbustivo-arbóreas com maiores valores de importância amostradas por Vincent et al. (1992), em Pirassununga, onde há predomínio de campo cerrado, somente duas estão entre as 15 mais importantes na ARIE Pé-de-Gigante.

Nas parcelas menores (Tabela 4.7), por sua vez, foram amostrados 714 indivíduos, pertencentes a 81 espécies e 38 famílias. As espécies com maiores valores de importância foram Loudetiopsis chrysothrix, Axonopus marginatus, Melinis minutiflora, Axonopus barbigerus e Byrsonima intermedia, que abrangeram 49,46\% do total. As quatro espécies de gramíneas mais importantes apresentaram valores de cobertura ainda maiores, refletindo padrão mais agregado em sua distribuição, e, novamente, a provável relevância da reprodução vegetativa para a ocupação do espaço. Dentro das dez populações mais abundantes, apenas Lippia salviifolia e Miconia albicans são do componente dominante. Isto ressalta a dificuldade dos diásporos das espécies do 
componente dominante se estabelecerem e germinarem sob grande cobertura herbácea. Para 21 das 81 espécies encontradas nestas parcelas, um indivíduo somente foi amostrado. Neste componente, Poaceae e Asteraceae foram as famílias mais ricas, com 9 espécies cada. Em seguida, apareceram Myrtaceae, representada por 7 espécies, e Cyperaceae e Rubiaceae, cada uma com 5 espécies.

Das 15 espécies herbáceo-subarbustivas com valores de importância mais altos amostradas por Vincent et al. (1992), apenas quatro estão entre as 15 mais importantes neste componente na ARIE Pé-de-Gigante, confirmando a heterogeneidade regional do cerrado.

Tabela 4.6 - Parâmetros fitossociológicos dos indivíduos das espécies lenhosas com diâmetro basal superior a $1 \mathrm{~cm}$ em campo cerrado na ARIE Cerrado Pé-de-Gigante, Santa Rita do Passa Quatro, São Paulo (21³6-44'S e 47³4-41'W), ordenados segundo o valor de importância. Legenda: no. ind. - número de indivíduos; Oc - ocorrência; $\mathrm{AB}=$ área basal $\left(\mathrm{m}^{2}\right)$; DR - densidade relativa $(\%)$; DoR - dominância relativa $(\%)$; FR - frequiência relativa $(\%)$; VC = valor de cobertura (\%); VI - valor de importância (\%).

\begin{tabular}{|c|c|c|c|c|c|c|c|c|}
\hline espécie & no. ind. & Oc & $\mathbf{A B}$ & DR & DoR & FR & $\mathrm{VC}$ & VI \\
\hline Pouteria torta & 83 & 8 & 0,3749 & 13,37 & 19,14 & 3,83 & 16,26 & 12,11 \\
\hline Anadenanthera falcata & 44 & 10 & 0,2169 & 7,09 & 11,08 & 4,78 & 9,09 & 7,65 \\
\hline Miconia albicans & 42 & 2 & 0,1870 & 6,76 & 9,55 & 0,96 & 8,16 & 5,76 \\
\hline Byrsonima intermedia & 34 & 9 & 0,0756 & 5,48 & 3,86 & 4,31 & 4,67 & 4,55 \\
\hline Ouratea spectabilis & 24 & 7 & 0,0855 & 3,86 & 4,37 & 3,35 & 4,12 & 3,86 \\
\hline Bauhinia rufa & 18 & 6 & 0,0530 & 2,90 & 2,71 & 2,87 & 2,81 & 2,83 \\
\hline Myrcia lingua & 16 & 7 & 0,0352 & 2,58 & 1,80 & 3,35 & 2,19 & 2,57 \\
\hline Tabebuia ochracea & 15 & 7 & 0,0232 & 2,42 & 1,18 & 3,35 & 1,80 & 2,32 \\
\hline Talisia angustifolia & 2 & 2 & 0,1036 & 0,32 & 5,29 & 0,96 & 2,81 & 2,19 \\
\hline Duguetia furfuracea & 21 & 4 & 0,0194 & 3,38 & 0,99 & 1,91 & 2,19 & 2,09 \\
\hline Qualea parviflora & 11 & 4 & 0,0450 & 1,77 & 2,30 & 1,91 & 2,04 & 1,99 \\
\hline Diospyros hispida & 15 & 5 & 0,0201 & 2,42 & 1,03 & 2,39 & 1,73 & 1,95 \\
\hline Aspidosperma tomentosum & 15 & 3 & 0,0386 & 2,42 & 1,97 & 1,44 & 2,20 & 1,94 \\
\hline Tocoyena formosa & 9 & 5 & 0,0329 & 1,45 & 1,68 & 2,39 & 1,57 & 1,84 \\
\hline Myrcia lasiantha & 13 & 3 & 0,0316 & 2,09 & 1,61 & 1,44 & 1,85 & 1,71 \\
\hline Gochnatia pulchra & 11 & 5 & 0,0139 & 1,77 & 0,71 & 2,39 & 1,24 & 1,62 \\
\hline Miconia ligustroides & 9 & 1 & 0,0557 & 1,45 & 2,84 & 0,48 & 2,15 & 1,59 \\
\hline Campomanesia pubescens & 15 & 4 & 0,0044 & 2,42 & 0,23 & 1,91 & 1,33 & 1,52 \\
\hline Protium heptaphyllum & 9 & 2 & 0,0389 & 1,45 & 1,98 & 0,96 & 1,72 & 1,46 \\
\hline Vernonia rubriramea & 12 & 4 & 0,0099 & 1,93 & 0,51 & 1,91 & 1,22 & 1,45 \\
\hline Toulicia tomentosa & 13 & 3 & 0,0130 & 2,09 & 0,66 & 1,44 & 1,38 & 1,40 \\
\hline Xylopia aromatica & 6 & 4 & 0,0197 & 0,97 & 1,01 & 1,91 & 0,99 & 1,30 \\
\hline Memora peregrine & 6 & 3 & 0,0225 & 0,97 & 1,15 & 1,44 & 1,06 & 1,18 \\
\hline Miconia rubiginosa & 8 & 1 & 0,0330 & 1,29 & 1,68 & 0,48 & 1,49 & 1,15 \\
\hline Senna rugosa & 7 & 4 & 0,0055 & 1,13 & 0,28 & 1,91 & 0,71 & 1,11 \\
\hline Annona coriacea & 5 & 4 & 0,0117 & 0,81 & 0,60 & 1,91 & 0,71 & 1,11 \\
\hline Qualea multiflora & 4 & 3 & 0,0236 & 0,64 & 1,21 & 1,44 & 0,93 & 1,10 \\
\hline Eupatorium squalidum & 7 & 4 & 0,0043 & 1,13 & 0,22 & 1,91 & 0,68 & 1,09 \\
\hline
\end{tabular}




\begin{tabular}{|c|c|c|c|c|c|c|c|c|}
\hline Leandra lacunosa & 4 & 3 & 0,0198 & 0,64 & 1,01 & 1,44 & 0,83 & 1,03 \\
\hline Copaifera langsdorfii & 5 & 3 & 0,0120 & 0,81 & 0,61 & 1,44 & 0,71 & 0,95 \\
\hline Qualea grandiflora & 3 & 2 & 0,0272 & 0,48 & 1,39 & 0,96 & 0,94 & 0,94 \\
\hline Syagrus loefgrenii & 7 & 2 & 0,0143 & 1,13 & 0,73 & 0,96 & 0,93 & 0,94 \\
\hline Miconia stenostachya & 6 & 2 & 0,0161 & 0,97 & 0,82 & 0,96 & 0,90 & 0,92 \\
\hline Qualea dichotoma & 4 & 2 & 0,0223 & 0,64 & 1,14 & 0,96 & 0,89 & 0,91 \\
\hline Banisteriopsis pubipetala & 8 & 1 & 0,0190 & 1,29 & 0,97 & 0,48 & 1,13 & 0,91 \\
\hline Annona crassiflora & 5 & 2 & 0,0163 & 0,81 & 0,83 & 0,96 & 0,82 & 0,87 \\
\hline Dyptichandra aurantiaca & 5 & 1 & 0,0247 & 0,81 & 1,26 & 0,48 & 1,04 & 0,85 \\
\hline Erythroxylum campestre & 4 & 3 & 0,0082 & 0,64 & 0,42 & 1,44 & 0,53 & 0,83 \\
\hline Lippia salviifolia & 4 & 3 & 0,0074 & 0,64 & 0,38 & 1,44 & 0,51 & 0,82 \\
\hline Eugenia livida & 7 & 2 & 0,0055 & 1,13 & 0,28 & 0,96 & 0,71 & 0,79 \\
\hline Vochysia cinamommea & 7 & 1 & 0,0135 & 1,13 & 0,69 & 0,48 & 0,91 & 0,77 \\
\hline Palicourea coriacea & 5 & 2 & 0,0085 & 0,81 & 0,43 & 0,96 & 0,62 & 0,73 \\
\hline Machaerium acutifolium & 3 & 3 & 0,0017 & 0,48 & 0,09 & 1,44 & 0,29 & 0,67 \\
\hline Arrabidaea brachypoda & 3 & 1 & 0,0196 & 0,48 & 1,00 & 0,48 & 0,74 & 0,65 \\
\hline Vatairea macrocarpa & 4 & 1 & 0,0152 & 0,64 & 0,77 & 0,48 & 0,71 & 0,63 \\
\hline Kielmeyera variabilis & 2 & 2 & 0,0110 & 0,32 & 0,56 & 0,96 & 0,44 & 0,61 \\
\hline Byrsonima coccolobifolia & 3 & 2 & 0,0060 & 0,48 & 0,31 & 0,96 & 0,40 & 0,58 \\
\hline Caryocar brasiliense & 3 & 2 & 0,0052 & 0,48 & 0,27 & 0,96 & 0,38 & 0,57 \\
\hline Davilla elliptica & 2 & 2 & 0,0083 & 0,32 & 0,42 & 0,96 & 0,37 & 0,57 \\
\hline Heteropteris byrsonimifolia & 4 & 2 & 0,0018 & 0,64 & 0,09 & 0,96 & 0,37 & 0,56 \\
\hline Stryphnodendron adstringens & 2 & 2 & 0,0035 & 0,32 & 0,18 & 0,96 & 0,25 & 0,49 \\
\hline Didymopanax vinosum & 2 & 2 & 0,0021 & 0,32 & 0,11 & 0,96 & 0,22 & 0,46 \\
\hline Casearia sylvestris & 2 & 2 & 0,0021 & 0,32 & 0,11 & 0,96 & 0,22 & 0,46 \\
\hline Palicourea rigida & 2 & 2 & 0,0017 & 0,32 & 0,08 & 0,96 & 0,20 & 0,45 \\
\hline Eugenia bimarginata & 1 & 1 & 0,0115 & 0,16 & 0,59 & 0,48 & 0,38 & 0,41 \\
\hline Couepia grandiflora & 4 & 1 & 0,0018 & 0,64 & 0,09 & 0,48 & 0,37 & 0,40 \\
\hline Jacaranda decurrens & 1 & 1 & 0,0079 & 0,16 & 0,40 & 0,48 & 0,28 & 0,35 \\
\hline Solanum erianthum & 3 & 1 & 0,0006 & 0,48 & 0,03 & 0,48 & 0,26 & 0,33 \\
\hline Distictella mansoana & 2 & 1 & 0,0036 & 0,32 & 0,18 & 0,48 & 0,25 & 0,33 \\
\hline Ocotea corymbosa & 1 & 1 & 0,0060 & 0,16 & 0,31 & 0,48 & 0,24 & 0,32 \\
\hline Byrsonima verbascifolia & 1 & 1 & 0,0050 & 0,16 & 0,25 & 0,48 & 0,21 & 0,30 \\
\hline Dimorphandra mollis & 1 & 1 & 0,0038 & 0,16 & 0,20 & 0,48 & 0,18 & 0,28 \\
\hline Banisteriopsis campestris & 2 & 1 & 0,0004 & 0,32 & 0,02 & 0,48 & 0,17 & 0,27 \\
\hline Viguiera discolor & 2 & 1 & 0,0003 & 0,32 & 0,02 & 0,48 & 0,17 & 0,27 \\
\hline Anadenanthera peregrina & 1 & 1 & 0,0032 & 0,16 & 0,16 & 0,48 & 0,16 & 0,27 \\
\hline Tabebuia aurea & 1 & 1 & 0,0030 & 0,16 & 0,15 & 0,48 & 0,16 & 0,26 \\
\hline Eugenia aurata & 1 & 1 & 0,0027 & 0,16 & 0,14 & 0,48 & 0,15 & 0,26 \\
\hline Pouteria ramiflora & 1 & 1 & 0,0026 & 0,16 & 0,13 & 0,48 & 0,15 & 0,26 \\
\hline Smilax cissoides & 1 & 1 & 0,0022 & 0,16 & 0,11 & 0,48 & 0,14 & 0,25 \\
\hline Banisteriopsis laevifolia & 1 & 1 & 0,0020 & 0,16 & 0,10 & 0,48 & 0,13 & 0,25 \\
\hline Eugenia punicifolia & 1 & 1 & 0,0020 & 0,16 & 0,10 & 0,48 & 0,13 & 0,25 \\
\hline Roupala montana & 1 & 1 & 0,0013 & 0,16 & 0,07 & 0,48 & 0,12 & 0,24 \\
\hline Myrcia bella & 1 & 1 & 0,0008 & 0,16 & 0,04 & 0,48 & 0,10 & 0,23 \\
\hline Connarus suberosus & 1 & 1 & 0,0008 & 0,16 & 0,04 & 0,48 & 0,10 & 0,23 \\
\hline Oxalis physocallyx & 1 & 1 & 0,0008 & 0,16 & 0,04 & 0,48 & 0,10 & 0,23 \\
\hline Baccharis rufescens & 1 & 1 & 0,0007 & 0,16 & 0,04 & 0,48 & 0,10 & 0,23 \\
\hline Declieuxia fruticosa & 1 & 1 & 0,0006 & 0,16 & 0,03 & 0,48 & 0,10 & 0,22 \\
\hline Dalbergia miscolobium & 1 & 1 & 0,0006 & 0,16 & 0,03 & 0,48 & 0,10 & 0,22 \\
\hline Gomphrena virgata & 1 & 1 & 0,0005 & 0,16 & 0,03 & 0,48 & 0,10 & 0,22 \\
\hline Banisteriopsis stellaris & 1 & 1 & 0,0004 & 0,16 & 0,02 & 0,48 & 0,09 & 0,22 \\
\hline Vanillosmopsis erythropappa & 1 & 1 & 0,0004 & 0,16 & 0,02 & 0,48 & 0,09 & 0,22 \\
\hline Hyptis reticulata & 1 & 1 & 0,0004 & 0,16 & 0,02 & 0,48 & 0,09 & 0,22 \\
\hline
\end{tabular}




\begin{tabular}{lllllllll} 
Psidium cinereum & 1 & 1 & 0,0004 & 0,16 & 0,02 & 0,48 & 0,09 & 0,22 \\
Neea theifera & 1 & 1 & 0,0002 & 0,16 & 0,01 & 0,48 & 0,09 & 0,22 \\
Solanum lycocarpum & 1 & 1 & 0,0002 & 0,16 & 0,01 & 0,48 & 0,09 & 0,22 \\
Baccharis dracunculifolia & 1 & 1 & 0,0002 & 0,16 & 0,01 & 0,48 & 0,09 & 0,22 \\
Sebastiania serrulata & 1 & 1 & 0,0001 & 0,16 & 0,01 & 0,48 & 0,09 & 0,22 \\
\hline
\end{tabular}

Tabela 4.7 - Parâmetros fitossociológicos dos indivíduos das espécies lenhosas com diâmetro basal até 0,9cm e nãolenhosas em campo cerrado na ARIE Cerrado Pé-de-Gigante, Santa Rita do Passa Quatro, São Paulo (21³6-44’S e 47³4-41’W), ordenados segundo o valor de importância. Legenda: no. ind. - número de indivíduos; Oc - ocorrência; $\mathrm{AB}=$ área basal $\left(\mathrm{m}^{2}\right) ; \mathrm{DR}$ - densidade relativa $(\%)$; DoR - dominância relativa $(\%)$ FR - freqüência relativa $(\%)$;C = valor de cobertura (\%); VI - valor de importância $(\%)$.

\begin{tabular}{|c|c|c|c|c|c|c|c|c|}
\hline espécie & no. ind. & Oc & $\mathbf{A B}$ & DR & DoR & FR & VC & VI \\
\hline Loudetiopsis chrysothrix & 54 & 7 & 0,1570 & 7,56 & 48,83 & 4,14 & 28,20 & 20,18 \\
\hline Axonopus marginatus & 107 & 7 & 0,0442 & 14,99 & 13,74 & 4,14 & 14,37 & 10,96 \\
\hline Melinis minutiflora & 42 & 4 & 0,0373 & 5,88 & 11,62 & 2,37 & 8,75 & 6,62 \\
\hline Axonopus barbigerus & 33 & 7 & 0,0332 & 4,62 & 10,32 & 4,14 & 7,47 & 6,36 \\
\hline Byrsonima intermedia & 73 & 9 & 0,0015 & 10,22 & 0,47 & 5,33 & 5,35 & 5,34 \\
\hline Echinolaena inflexa & 73 & 6 & 0,0012 & 10,22 & 0,36 & 3,55 & 5,29 & 4,71 \\
\hline Tristachya leiostachya & 6 & 2 & 0,0239 & 0,84 & 7,42 & 1,18 & 4,13 & 3,15 \\
\hline Cyperus diffusus & 18 & 4 & 0,0038 & 2,52 & 1,18 & 2,37 & 1,85 & 2,02 \\
\hline Lippia salviifolia & 22 & 4 & 0,0004 & 3,08 & 0,12 & 2,37 & 1,60 & 1,86 \\
\hline Banisteriopsis stellaris & 17 & 3 & 0,0001 & 2,38 & 0,02 & 1,78 & 1,20 & 1,39 \\
\hline Eupatorium squalidum & 8 & 4 & 0,0001 & 1,12 & 0,03 & 2,37 & 0,58 & 1,17 \\
\hline Miconia albicans & 16 & 2 & 0,0003 & 2,24 & 0,09 & 1,18 & 1,17 & 1,17 \\
\hline Cissampelos ovalifolia & 8 & 4 & 0,0001 & 1,12 & 0,02 & 2,37 & 0,57 & 1,17 \\
\hline Aspidosperma tomentosum & 10 & 3 & 0,0003 & 1,40 & 0,08 & 1,78 & 0,74 & 1,09 \\
\hline Tabebuia ochracea & 5 & 4 & 0,0002 & 0,70 & 0,05 & 2,37 & 0,38 & 1,04 \\
\hline Scleria comosa & 5 & 3 & 0,0016 & 0,70 & 0,51 & 1,78 & 0,61 & 0,99 \\
\hline Ichnanthus sericeus & 4 & 1 & 0,0052 & 0,56 & 1,62 & 0,59 & 1,09 & 0,93 \\
\hline Croton eriocladus & 11 & 2 & 0,0001 & 1,54 & 0,03 & 1,18 & 0,79 & 0,92 \\
\hline Myrcia lingua & 5 & 3 & 0,0002 & 0,70 & 0,05 & 1,78 & 0,38 & 0,84 \\
\hline Gochnatia pulchra & 5 & 3 & 0,0001 & 0,70 & 0,03 & 1,78 & 0,37 & 0,83 \\
\hline Palicourea coriacea & 9 & 2 & 0,0002 & 1,26 & 0,06 & 1,18 & 0,66 & 0,83 \\
\hline Casearia sylvestris & 5 & 3 & 0,0001 & 0,70 & 0,02 & 1,78 & 0,36 & 0,83 \\
\hline Trichogonia salviifolia & 9 & 2 & 0,0001 & 1,26 & 0,04 & 1,18 & 0,65 & 0,83 \\
\hline Sebastiania serrulata & 5 & 3 & 0,0000 & 0,70 & 0,01 & 1,78 & 0,36 & 0,83 \\
\hline Protium heptaphyllum & 9 & 2 & 0,0001 & 1,26 & 0,04 & 1,18 & 0,65 & 0,83 \\
\hline Bulbostylis hirtella & 2 & 2 & 0,0031 & 0,28 & 0,98 & 1,18 & 0,63 & 0,81 \\
\hline Pouteria torta & 4 & 3 & 0,0001 & 0,56 & 0,05 & 1,78 & 0,31 & 0,79 \\
\hline Anacardium humile & 8 & 2 & 0,0002 & 1,12 & 0,06 & 1,18 & 0,59 & 0,79 \\
\hline Alternanthera brasiliana & 4 & 3 & 0,0001 & 0,56 & 0,02 & 1,78 & 0,29 & 0,78 \\
\hline Syagrus loefgrenii & 7 & 2 & 0,0004 & 0,98 & 0,14 & 1,18 & 0,56 & 0,77 \\
\hline Rourea induta & 7 & 2 & 0,0001 & 0,98 & 0,02 & 1,18 & 0,50 & 0,73 \\
\hline Diospyros hispida & 6 & 2 & 0,0002 & 0,84 & 0,07 & 1,18 & 0,46 & 0,70 \\
\hline Miconia stenostachya & 9 & 1 & 0,0002 & 1,26 & 0,07 & 0,59 & 0,67 & 0,64 \\
\hline Bauhinia rufa & 5 & 2 & 0,0000 & 0,70 & 0,01 & 1,18 & 0,36 & 0,63 \\
\hline Aristida jubata & 2 & 2 & 0,0013 & 0,28 & 0,40 & 1,18 & 0,34 & 0,62 \\
\hline Panicum parvifolium & 8 & 1 & 0,0003 & 1,12 & 0,08 & 0,59 & 0,60 & 0,60 \\
\hline Memora peregrine & 4 & 2 & 0,0001 & 0,56 & 0,04 & 1,18 & 0,30 & 0,59 \\
\hline Dickia tuberosa & 2 & 1 & 0,0026 & 0,28 & 0,80 & 0,59 & 0,54 & 0,56 \\
\hline Cyperus cayennensis & 3 & 2 & 0,0002 & 0,42 & 0,05 & 1,18 & 0,24 & 0,55 \\
\hline
\end{tabular}




\begin{tabular}{|c|c|c|c|c|c|c|c|c|}
\hline Palicourea rigida & 3 & 2 & 0,0001 & 0,42 & 0,03 & 1,18 & 0,23 & 0,54 \\
\hline Campomanesia pubescens & 3 & 2 & 0,0000 & 0,42 & 0,01 & 1,18 & 0,22 & 0,54 \\
\hline Manihot tripartita & 3 & 2 & 0,0000 & 0,42 & 0,01 & 1,18 & 0,22 & 0,54 \\
\hline Ouratea spectabilis & 2 & 2 & 0,0001 & 0,28 & 0,03 & 1,18 & 0,16 & 0,50 \\
\hline Froelichia lanata & 2 & 2 & 0,0000 & 0,28 & 0,01 & 1,18 & 0,15 & 0,49 \\
\hline Smilax cissoides & 2 & 2 & 0,0000 & 0,28 & 0,01 & 1,18 & 0,15 & 0,49 \\
\hline Eugenia livida & 6 & 1 & 0,0001 & 0,84 & 0,03 & 0,59 & 0,44 & 0,49 \\
\hline Diodia schumanii & 6 & 1 & 0,0000 & 0,84 & 0,01 & 0,59 & 0,43 & 0,48 \\
\hline Duguetia furfuracea & 5 & 1 & 0,0002 & 0,70 & 0,07 & 0,59 & 0,39 & 0,46 \\
\hline Eugenia langsdorfii & 5 & 1 & 0,0001 & 0,70 & 0,03 & 0,59 & 0,37 & 0,44 \\
\hline Peltodon tomentosus & 4 & 1 & 0,0000 & 0,56 & 0,01 & 0,59 & 0,29 & 0,39 \\
\hline Andira laurifolia & 3 & 1 & 0,0000 & 0,42 & 0,01 & 0,59 & 0,22 & 0,34 \\
\hline Davilla elliptica & 3 & 1 & 0,0000 & 0,42 & 0,00 & 0,59 & 0,21 & 0,34 \\
\hline Alibertia sessilis & 2 & 1 & 0,0001 & 0,28 & 0,02 & 0,59 & 0,15 & 0,30 \\
\hline Eugenia punicifolia & 2 & 1 & 0,0001 & 0,28 & 0,02 & 0,59 & 0,15 & 0,30 \\
\hline Neea theifera & 2 & 1 & 0,0000 & 0,28 & 0,01 & 0,59 & 0,15 & 0,29 \\
\hline Talisia angustifolia & 2 & 1 & 0,0000 & 0,28 & 0,01 & 0,59 & 0,15 & 0,29 \\
\hline Pterocaulon rugosum & 2 & 1 & 0,0000 & 0,28 & 0,01 & 0,59 & 0,15 & 0,29 \\
\hline Erythroxylum campestre & 2 & 1 & 0,0000 & 0,28 & 0,01 & 0,59 & 0,15 & 0,29 \\
\hline Commelina erecta & 2 & 1 & 0,0000 & 0,28 & 0,00 & 0,59 & 0,14 & 0,29 \\
\hline Eriosema crinitum & 2 & 1 & 0,0000 & 0,28 & 0,00 & 0,59 & 0,14 & 0,29 \\
\hline Psidium australe & 1 & 1 & 0,0001 & 0,14 & 0,02 & 0,59 & 0,08 & 0,25 \\
\hline Solanum lycocarpum & 1 & 1 & 0,0001 & 0,14 & 0,02 & 0,59 & 0,08 & 0,25 \\
\hline Toulicia tomentosa & 1 & 1 & 0,0001 & 0,14 & 0,02 & 0,59 & 0,08 & 0,25 \\
\hline Vernonia rubriramea & 1 & 1 & 0,0000 & 0,14 & 0,01 & 0,59 & 0,08 & 0,25 \\
\hline Dalbergia miscolobium & 1 & 1 & 0,0000 & 0,14 & 0,01 & 0,59 & 0,08 & 0,25 \\
\hline Viguiera discolor & 1 & 1 & 0,0000 & 0,14 & 0,01 & 0,59 & 0,08 & 0,25 \\
\hline Achyrocline satureoides & 1 & 1 & 0,0000 & 0,14 & 0,01 & 0,59 & 0,08 & 0,25 \\
\hline Sida glaziovii & 1 & 1 & 0,0000 & 0,14 & 0,01 & 0,59 & 0,08 & 0,25 \\
\hline Roupala montana & 1 & 1 & 0,0000 & 0,14 & 0,01 & 0,59 & 0,08 & 0,25 \\
\hline Rhynchospora exaltata & 1 & 1 & 0,0000 & 0,14 & 0,00 & 0,59 & 0,07 & 0,25 \\
\hline Eupatorium chlorolepsis & 1 & 1 & 0,0000 & 0,14 & 0,00 & 0,59 & 0,07 & 0,24 \\
\hline Declieuxia fruticosa & 1 & 1 & 0,0000 & 0,14 & 0,00 & 0,59 & 0,07 & 0,24 \\
\hline Sida rhombifolia & 1 & 1 & 0,0000 & 0,14 & 0,00 & 0,59 & 0,07 & 0,24 \\
\hline Eupatorium maximiliani & 1 & 1 & 0,0000 & 0,14 & 0,00 & 0,59 & 0,07 & 0,24 \\
\hline Phyllanthus orbiculatus & 1 & 1 & 0,0000 & 0,14 & 0,00 & 0,59 & 0,07 & 0,24 \\
\hline Connarus suberosus & 1 & 1 & 0,0000 & 0,14 & 0,00 & 0,59 & 0,07 & 0,24 \\
\hline Cissus erosa & 1 & 1 & 0,0000 & 0,14 & 0,00 & 0,59 & 0,07 & 0,24 \\
\hline Styrax ferrugineus & 1 & 1 & 0,0000 & 0,14 & 0,00 & 0,59 & 0,07 & 0,24 \\
\hline Crotalaria vitellina & 1 & 1 & 0,0000 & 0,14 & 0,00 & 0,59 & 0,07 & 0,24 \\
\hline Oxalis physocallyx & 1 & 1 & 0,0000 & 0,14 & 0,00 & 0,59 & 0,07 & 0,24 \\
\hline Eugenia bimarginata & 1 & 1 & 0,0000 & 0,14 & 0,00 & 0,59 & 0,07 & 0,24 \\
\hline
\end{tabular}

\section{Floresta estacional semidecídua}

As espécies amostradas na floresta estacional semidecídua, ordenadas pelo valor de importância (VI), estão reunidas nas Tabelas 4.8 (indivíduos lenhosos com mais de 10cm de diâmetro basal), 4.9 
(indivíduos lenhosos com diâmetro basal entre 1 e 9,9cm) e 4.10 (indivíduos lenhosos com até 0,9cm de diâmetro basal e não-lenhosos).

Nas parcelas maiores (Tabela 4.8), foram amostrados 140 indivíduos, representando 38 espécies e 21 famílias. As espécies mais importantes foram Platypodium elegans, Croton floribundus, Tabebuia serratifolia, Machaerium villosum e Anadenanthera macrocarpa, que compreenderam $46,76 \%$ do total. As ordenações pelo valor de importância e pelo valor de cobertura foram as mesmas, pelo menos para as dez espécies mais representativas. Foi encontrado um indivíduo apenas de 15 espécies amostradas. Neste componente, Fabaceae foi a família com maior riqueza, sendo representada por 9 espécies. A esta família, seguiu-se Caesalpiniaceae, com 3 espécies.

Já nas parcelas intermediárias (Tabela 4.9), foram amostrados 724 indivíduos, pertencentes a 68 espécies e 30 famílias. Actinostemon communis foi, neste componente, a espécie mais importante, com 20,37\% do valor de importância total. Seu valor de cobertura foi ainda maior, com $28,02 \%$ do total. Esenbeckia febrifuga, Cupania vernalis, Croton floribundus e Casearia grandiflora apareceram em seguida, com 22,26\% do total. Esenbeckia febrifuga apresentou-se com distribuição mais agregada, sendo representada por 65 indivíduos em 4 parcelas. Das 68 espécies amostradas, 15 o foram por uma única vez. As famílias com maiores riquezas foram Fabaceae e Rubiaceae (7 espécies cada) e Sapindaceae (6 espécies).

Nas parcelas menores (Tabela 4.10), foram amostrados 427 indivíduos, pertencentes a 68 espécies e 26 famílias. Como na classe anterior, Actinostemon communis foi a espécie com maior valor de importância, sendo responsável por quase metade do total $(42,01 \%)$. As outras espécies mais importantes foram Hybanthus atropurpureus, Olyra micrantha, Psychotria barbiflora e Cupania vernalis, que abrangeram $18,59 \%$ do total. Entre as dez populações com maiores densidades, Cupania vernalis, Tabebuia serratifolia e Amaioua guianensis foram as espécies dos componentes dominante e intermediário que se destacaram com maiores potenciais de regeneração. 
Foram representadas somente por um indivíduo 18 espécies. Rubiaceae, com 7 espécies, foi a família mais rica. Em seguida, surgiram Sapindaceae e Fabaceae, cada uma representada por 3 espécies.

Tabela 4.8 - Parâmetros fitossociológicos dos indivíduos das espécies lenhosas com diâmetro basal igual ou superior a $10 \mathrm{~cm}$ em floresta estacional semidecídua na ARIE Cerrado Pé-de-Gigante, Santa Rita do Passa Quatro, São Paulo (21³6-44'S e 47³4-41’W), ordenados segundo o valor de importância. Legenda: no. ind. - número de indivíduos; Oc - ocorrência; $\mathrm{AB}=$ área basal $\left(\mathrm{m}^{2}\right)$; DR - densidade relativa (\%); DoR - dominância relativa (\%); FR - frequiência relativa $(\%) ; \mathrm{VC}=$ valor de cobertura $(\%)$; VI - valor de importância $(\%)$.

\begin{tabular}{|c|c|c|c|c|c|c|c|c|}
\hline espécie & no. ind. & Oc & $\overline{A B}$ & DR & DoR & FR & $\overline{\mathrm{VC}}$ & $\overline{\text { VI }}$ \\
\hline Platypodium elegans & 12 & 7 & 1,2985 & 8,57 & 20,72 & 7,87 & 14,65 & 12,38 \\
\hline Croton floribundus & 24 & 6 & 0,5366 & 17,14 & 8,56 & 6,74 & 12,85 & 10,82 \\
\hline Tabebuia serratifolia & 13 & 8 & 0,7794 & 9,29 & 12,43 & 8,99 & 10,86 & 10,24 \\
\hline Machaerium villosum & 6 & 4 & 0,7075 & 4,29 & 11,29 & 4,49 & 7,79 & 6,69 \\
\hline Anadenanthera macrocarpa & 5 & 4 & 0,7412 & 3,57 & 11,82 & 4,49 & 7,70 & 6,63 \\
\hline Copaifera langsdorfii & 9 & 4 & 0,2087 & 6,43 & 3,33 & 4,49 & 4,88 & 4,75 \\
\hline Nectandra megapotamica & 7 & 4 & 0,1447 & 5,00 & 2,31 & 4,49 & 3,66 & 3,93 \\
\hline Machaerium aculeatum & 5 & 3 & 0,1770 & 3,57 & 2,82 & 3,37 & 3,20 & 3,26 \\
\hline Aspidosperma cylindrocarpon & 5 & 4 & 0,0900 & 3,57 & 1,44 & 4,49 & 2,51 & 3,17 \\
\hline Luehea divaricata & 3 & 3 & 0,0879 & 2,14 & 1,40 & 3,37 & 1,77 & 2,31 \\
\hline Zanthoxylum riedelianum & 3 & 3 & 0,0725 & 2,14 & 1,16 & 3,37 & 1,65 & 2,22 \\
\hline Cordia sellowiana & 3 & 3 & 0,0633 & 2,14 & 1,01 & 3,37 & 1,58 & 2,17 \\
\hline Aloysia virgata & 4 & 2 & 0,0628 & 2,86 & 1,00 & 2,25 & 1,93 & 2,04 \\
\hline Qualea grandiflora & 1 & 1 & 0,2665 & 0,71 & 4,25 & 1,12 & 2,48 & 2,03 \\
\hline Ocotea corymbosa & 5 & 1 & 0,0812 & 3,57 & 1,30 & 1,12 & 2,44 & 2,00 \\
\hline Vatairea macrocarpa & 2 & 2 & 0,1387 & 1,43 & 2,21 & 2,25 & 1,82 & 1,96 \\
\hline Andira cuiabensis & 3 & 2 & 0,0588 & 2,14 & 0,94 & 2,25 & 1,54 & 1,78 \\
\hline Platyciamus regnellii & 3 & 2 & 0,0574 & 2,14 & 0,92 & 2,25 & 1,53 & 1,77 \\
\hline Coussarea hydrangeaefolia & 3 & 2 & 0,0534 & 2,14 & 0,85 & 2,25 & 1,50 & 1,75 \\
\hline Terminalia brasiliensis & 2 & 2 & 0,0757 & 1,43 & 1,21 & 2,25 & 1,32 & 1,63 \\
\hline Hymenaea courbaril & 2 & 2 & 0,0717 & 1,43 & 1,14 & 2,25 & 1,29 & 1,61 \\
\hline Machaerium stipitatum & 1 & 1 & 0,1627 & 0,71 & 2,60 & 1,12 & 1,66 & 1,48 \\
\hline Aspidosperma ramiflorum & 2 & 2 & 0,0374 & 1,43 & 0,60 & 2,25 & 1,02 & 1,42 \\
\hline Casearia grandiflora & 2 & 2 & 0,0368 & 1,43 & 0,59 & 2,25 & 1,01 & 1,42 \\
\hline Roupala montana & 2 & 2 & 0,0213 & 1,43 & 0,34 & 2,25 & 0,89 & 1,34 \\
\hline Campomanesia guazumifolia & 1 & 1 & 0,0630 & 0,71 & 1,01 & 1,12 & 0,86 & 0,95 \\
\hline Cupania vernalis & 1 & 1 & 0,0224 & 0,71 & 0,36 & 1,12 & 0,54 & 0,73 \\
\hline Sclerolobium paniculatum & 1 & 1 & 0,0224 & 0,71 & 0,36 & 1,12 & 0,54 & 0,73 \\
\hline Ouratea castaneaefolia & 1 & 1 & 0,0168 & 0,71 & 0,27 & 1,12 & 0,49 & 0,70 \\
\hline Dalbergia frutescens & 1 & 1 & 0,0161 & 0,71 & 0,26 & 1,12 & 0,49 & 0,70 \\
\hline Cedrela fissilis & 1 & 1 & 0,0147 & 0,71 & 0,23 & 1,12 & 0,47 & 0,69 \\
\hline Machaerium acutifolium & 1 & 1 & 0,0140 & 0,71 & 0,22 & 1,12 & 0,47 & 0,69 \\
\hline Magonia pubescens & 1 & 1 & 0,0140 & 0,71 & 0,22 & 1,12 & 0,47 & 0,69 \\
\hline Virola sebifera & 1 & 1 & 0,0121 & 0,71 & 0,19 & 1,12 & 0,45 & 0,68 \\
\hline Zeyhera tuberculosa & 1 & 1 & 0,0121 & 0,71 & 0,19 & 1,12 & 0,45 & 0,68 \\
\hline Vochysia tucanorum & 1 & 1 & 0,0109 & 0,71 & 0,17 & 1,12 & 0,44 & 0,67 \\
\hline Aegiphila sellowiana & 1 & 1 & 0,0097 & 0,71 & 0,16 & 1,12 & 0,44 & 0,66 \\
\hline
\end{tabular}


Tabela 4.9 - Parâmetros fitossociológicos dos indivíduos das espécies lenhosas com diâmetro basal entre 1 e 9,9cm em floresta estacional semidecídua na ARIE Cerrado Pé-de-Gigante, Santa Rita do Passa Quatro, São Paulo (21³6-44’S e 47³4-41'W), ordenados segundo o valor de importância. Legenda: no. ind. - número de indivíduos; Oc ocorrência; $\mathrm{AB}=$ área basal $\left(\mathrm{m}^{2}\right)$; DR - densidade relativa $(\%)$; DoR - dominância relativa $(\%)$; FR - frequiência relativa (\%); VC = valor de cobertura (\%); VI - valor de importância (\%).

\begin{tabular}{|c|c|c|c|c|c|c|c|c|}
\hline espécie & no. ind. & Oc & $\overline{A B}$ & $\mathbf{D R}$ & DoR & FR & VC & VI \\
\hline Actinostemon communis & 286 & 9 & 0,0787 & 39,50 & 16,54 & "5,06 & 28,02 & 20,37 \\
\hline Esenbeckia febrifuga & 65 & 4 & 0,0513 & 8,98 & 10,78 & 2,25 & 9,88 & 7,33 \\
\hline Cupania vernalis & 48 & 9 & 0,0438 & 6,63 & 9,21 & 5,06 & 7,92 & 6,97 \\
\hline Croton floribundus & 14 & 7 & 0,0296 & 1,93 & 6,23 & 3,93 & 4,08 & 4,03 \\
\hline Casearia grandiflora & 18 & 8 & 0,0229 & 2,49 & 4,82 & 4,49 & 3,66 & 3,93 \\
\hline Bauhinia forficata & 17 & 6 & 0,0126 & 2,35 & 2,64 & 3,37 & 2,50 & 2,79 \\
\hline Copaifera langsdorfii & 16 & 7 & 0,0103 & 2,21 & 2,17 & 3,93 & 2,19 & 2,77 \\
\hline Tetrapteris guilleminiana & 17 & 6 & 0,0091 & 2,35 & 1,92 & 3,37 & 2,14 & 2,55 \\
\hline Eugenia florida & 17 & 6 & 0,0087 & 2,35 & 1,83 & 3,37 & 2,09 & 2,52 \\
\hline Pyrostegia venusta & 16 & 5 & 0,0115 & 2,21 & 2,42 & 2,81 & 2,32 & 2,48 \\
\hline Virola sebifera & 9 & 4 & 0,0165 & 1,24 & 3,47 & 2,25 & 2,36 & 2,32 \\
\hline Paullinia elegans & 7 & 5 & 0,0069 & 0,97 & 1,45 & 2,81 & 1,21 & 1,74 \\
\hline Matayba elaeagnoides & 10 & 3 & 0,0099 & 1,38 & 2,08 & 1,69 & 1,73 & 1,72 \\
\hline Aspidosperma ramiflorum & 4 & 3 & 0,0131 & 0,55 & 2,75 & 1,69 & 1,65 & 1,66 \\
\hline Aspidosperma cylindrocarpon & 7 & 4 & 0,0079 & 0,97 & 1,66 & 2,25 & 1,32 & 1,62 \\
\hline Casearia sylvestris & 6 & 5 & 0,0053 & 0,83 & 1,11 & 2,81 & 0,97 & 1,58 \\
\hline Amaioua guianensis & 6 & 3 & 0,0094 & 0,83 & 1,97 & 1,69 & 1,40 & 1,49 \\
\hline Protium heptaphyllum & 13 & 2 & 0,0071 & 1,80 & 1,48 & 1,12 & 1,64 & 1,47 \\
\hline Aspidosperma cuspa & 4 & 2 & 0,0107 & 0,55 & 2,25 & 1,12 & 1,40 & 1,31 \\
\hline Arrabidaea pulchella & 7 & 3 & 0,0058 & 0,97 & 1,23 & 1,69 & 1,10 & 1,29 \\
\hline Machaerium aculeatum & 8 & 4 & 0,0020 & 1,10 & 0,42 & 2,25 & 0,76 & 1,26 \\
\hline Nectandra megapotamica & 8 & 3 & 0,0045 & 1,10 & 0,96 & 1,69 & 1,03 & 1,25 \\
\hline Hybanthus atropurpureus & 9 & 3 & 0,0035 & 1,24 & 0,74 & 1,69 & 0,99 & 1,22 \\
\hline Terminalia brasiliensis & 5 & 4 & 0,0033 & 0,69 & 0,70 & 2,25 & 0,70 & 1,21 \\
\hline Magonia pubescens & 6 & 2 & 0,0077 & 0,83 & 1,63 & 1,12 & 1,23 & 1,19 \\
\hline Anadenanthera macrocarpa & 6 & 3 & 0,0049 & 0,83 & 1,04 & 1,69 & 0,94 & 1,18 \\
\hline Serjania reticulata & 5 & 3 & 0,0053 & 0,69 & 1,12 & 1,69 & 0,91 & 1,16 \\
\hline Andira cuiabensis & 4 & 1 & 0,0102 & 0,55 & 2,15 & 0,56 & 1,35 & 1,09 \\
\hline Platypodium elegans & 5 & 3 & 0,0022 & 0,69 & 0,45 & 1,69 & 0,57 & 0,94 \\
\hline Coussarea hydrangeaefolia & 4 & 3 & 0,0028 & 0,55 & 0,58 & 1,69 & 0,57 & 0,94 \\
\hline Guapira olfersiana & 3 & 2 & 0,0058 & 0,41 & 1,23 & 1,12 & 0,82 & 0,92 \\
\hline Trichilia hirta & 6 & 1 & 0,0059 & 0,83 & 1,23 & 0,56 & 1,03 & 0,88 \\
\hline Ocotea corymbosa & 3 & 2 & 0,0043 & 0,41 & 0,91 & 1,12 & 0,66 & 0,82 \\
\hline Luehea divaricata & 2 & 1 & 0,0074 & 0,28 & 1,56 & 0,56 & 0,92 & 0,80 \\
\hline Zeyhera tuberculosa & 3 & 3 & 0,0009 & 0,41 & 0,19 & 1,69 & 0,30 & 0,76 \\
\hline Cremastus pulcher & 5 & 2 & 0,0022 & 0,69 & 0,47 & 1,12 & 0,58 & 0,76 \\
\hline Roupala montana & 2 & 2 & 0,0014 & 0,28 & 0,30 & 1,12 & 0,29 & 0,57 \\
\hline Tabebuia serratifolia & 2 & 2 & 0,0008 & 0,28 & 0,17 & 1,12 & 0,23 & 0,52 \\
\hline Siphoneugenia regnelliana & 4 & 1 & 0,0021 & 0,55 & 0,45 & 0,56 & 0,50 & 0,52 \\
\hline Lacistema floribundum & 5 & 1 & 0,0014 & 0,69 & 0,30 & 0,56 & 0,50 & 0,52 \\
\hline Guapira opposita & 2 & 1 & 0,0033 & 0,28 & 0,70 & 0,56 & 0,49 & 0,51 \\
\hline Rhamnidium eleocarpum & 2 & 2 & 0,0006 & 0,28 & 0,13 & 1,12 & 0,21 & 0,51 \\
\hline Platyciamus regnellii & 2 & 2 & 0,0005 & 0,28 & 0,12 & 1,12 & 0,20 & 0,50 \\
\hline
\end{tabular}




\begin{tabular}{lllllllll} 
Hymenaea courbaril & 1 & 1 & 0,0038 & 0,14 & 0,81 & 0,56 & 0,48 & 0,50 \\
Acacia polyphylla & 2 & 2 & 0,0003 & 0,28 & 0,07 & 1,12 & 0,18 & 0,49 \\
Machaerium villosum & 1 & 1 & 0,0032 & 0,14 & 0,68 & 0,56 & 0,41 & 0,46 \\
Guatteria australis & 3 & 1 & 0,0015 & 0,41 & 0,31 & 0,56 & 0,36 & 0,43 \\
Xylopia aromatica & 1 & 1 & 0,0026 & 0,14 & 0,56 & 0,56 & 0,35 & 0,42 \\
Randia spinosa & 3 & 1 & 0,0012 & 0,41 & 0,26 & 0,56 & 0,34 & 0,41 \\
Astronium graveolens & 2 & 1 & 0,0017 & 0,28 & 0,35 & 0,56 & 0,32 & 0,40 \\
Temnadenia violacea & 3 & 1 & 0,0007 & 0,41 & 0,15 & 0,56 & 0,28 & 0,38 \\
Machaerium stipitatum & 3 & 1 & 0,0007 & 0,41 & 0,15 & 0,56 & 0,28 & 0,37 \\
Myrcia tomentosa & 2 & 1 & 0,0007 & 0,28 & 0,15 & 0,56 & 0,22 & 0,33 \\
Psychotria barbiflora & 1 & 1 & 0,0008 & 0,14 & 0,17 & 0,56 & 0,16 & 0,29 \\
Dalbergia frutescens & 1 & 1 & 0,0005 & 0,14 & 0,10 & 0,56 & 0,12 & 0,27 \\
Mesechites mansoana & 1 & 1 & 0,0005 & 0,14 & 0,10 & 0,56 & 0,12 & 0,27 \\
Tapirira guianensis & 1 & 1 & 0,0005 & 0,14 & 0,10 & 0,56 & 0,12 & 0,27 \\
Myrciaria floribunda & 1 & 1 & 0,0004 & 0,14 & 0,08 & 0,56 & 0,11 & 0,26 \\
Palicourea crocea & 1 & 1 & 0,0003 & 0,14 & 0,06 & 0,56 & 0,10 & 0,25 \\
Ixora venulosa & 1 & 1 & 0,0003 & 0,14 & 0,06 & 0,56 & 0,10 & 0,25 \\
Qualea grandiflora & 1 & 1 & 0,0003 & 0,14 & 0,06 & 0,56 & 0,10 & 0,25 \\
Strychnos bicolor & 1 & 1 & 0,0002 & 0,14 & 0,05 & 0,56 & 0,10 & 0,25 \\
Guettarda vibrunoides & 1 & 1 & 0,0002 & 0,14 & 0,05 & 0,56 & 0,10 & 0,25 \\
Ouratea castaneaefolia & 1 & 1 & 0,0002 & 0,14 & 0,04 & 0,56 & 0,09 & 0,25 \\
Serjania lethalis & 1 & 1 & 0,0002 & 0,14 & 0,03 & 0,56 & 0,09 & 0,24 \\
Ouratea semiserrata & 1 & 1 & 0,0001 & 0,14 & 0,02 & 0,56 & 0,08 & 0,24 \\
Siparuna guianensis & 1 & 1 & 0,0001 & 0,14 & 0,02 & 0,56 & 0,08 & 0,24 \\
Smilax cissoides & 1 & 1 & 0,0001 & 0,14 & 0,02 & 0,56 & 0,08 & 0,24 \\
\hline
\end{tabular}

Tabela 4.10 - Parâmetros fitossociológicos dos indivíduos das espécies lenhosas com diâmetro basal até 0,9cm e não-

lenhosas em floresta estacional semidecídua na ARIE Cerrado Pé-de-Gigante, Santa Rita do Passa Quatro, São Paulo (21³6-44’S e 47³4-41’W), ordenados segundo o valor de importância. Legenda: no. ind. - número de indivíduos;

$\mathrm{Oc}$ - ocorrência; $\mathrm{AB}$ = área basal $\left(\mathrm{m}^{2}\right)$; $\mathrm{DR}$ - densidade relativa (\%); DoR - dominância relativa (\%); FR - frequiência relativa (\%); VC = valor de cobertura (\%); VI - valor de importância (\%).

\begin{tabular}{lcccccccc}
\hline \multicolumn{1}{c}{ espécie } & no. ind. & Oc & AB & DR & DoR & FR & VC & VI \\
\hline Actinostemon communis & 212 & 10 & 0,0037 & 49,65 & 65,85 & 10,53 & 57,75 & 42,01 \\
Hybanthus atropurpureus & 49 & 5 & 0,0002 & 11,48 & 3,82 & 5,26 & 7,65 & 6,85 \\
Olyra micrantha & 25 & 6 & 0,0002 & 5,85 & 3,73 & 6,32 & 4,79 & 5,30 \\
Psychotria barbiflora & 20 & 5 & 0,0001 & 4,68 & 0,95 & 5,26 & 2,82 & 3,63 \\
Cupania vernalis & 10 & 2 & 0,0002 & 2,34 & 3,99 & 2,11 & 3,17 & 2,81 \\
Pyrostegia venusta & 9 & 4 & 0,0001 & 2,11 & 2,10 & 4,21 & 2,11 & 2,81 \\
Machaerium aculeatum & 7 & 4 & 0,0001 & 1,64 & 1,66 & 4,21 & 1,65 & 2,50 \\
Tetrapteris guilleminiana & 4 & 4 & 0,0001 & 0,94 & 1,85 & 4,21 & 1,40 & 2,33 \\
Serjania reticulata & 8 & 3 & 0,0001 & 1,87 & 1,72 & 3,16 & 1,80 & 2,25 \\
Croton floribundus & 5 & 4 & 0,0001 & 1,17 & 1,22 & 4,21 & 1,20 & 2,20 \\
Tabebuia serratifolia & 8 & 3 & 0,0000 & 1,87 & 0,57 & 3,16 & 1,22 & 1,87 \\
Esenbeckia febrifuga & 4 & 3 & 0,0001 & 0,94 & 1,29 & 3,16 & 1,12 & 1,79 \\
Amaioua guianensis & 6 & 2 & 0,0001 & 1,41 & 1,52 & 2,11 & 1,47 & 1,68 \\
Eugenia florida & 6 & 3 & 0,0000 & 1,41 & 0,20 & 3,16 & 0,81 & 1,59 \\
Guatteria australis & 3 & 3 & 0,0001 & 0,70 & 0,62 & 3,16 & 0,97 & 1,49 \\
Coussarea hydrangeaefolia & 3 & 2 & 0,0000 & 0,70 & 1,23 & 2,11 & 0,74 & 1,35 \\
Psychotria capitata & 5 & 2 & 0,0000 & 1,17 & 0,31 & 2,11 & 0,50 & 1,20 \\
Platypodium elegans & 4 & 2 & 0,0000 & 0,94 & 0,06 & 2,11 & 0,45 & 1,03 \\
Rudgea viburnoides & 2 & 2 & 0,0000 & 0,47 & 0,43 & 2,11 & 0,44 & 1,00
\end{tabular}




\begin{tabular}{lllllllll} 
Strychnos bicolor & 2 & 2 & 0,0000 & 0,47 & 0,40 & 2,11 & 0,44 & 0,99 \\
Paullinia elegans & 2 & 2 & 0,0000 & 0,47 & 0,16 & 2,11 & 0,32 & 0,91 \\
Bauhinia forficata & 2 & 2 & 0,0000 & 0,47 & 0,03 & 2,11 & 0,25 & 0,87 \\
Dioscorea amaranthoides & 2 & 1 & 0,0001 & 0,47 & 0,94 & 1,05 & 0,71 & 0,82 \\
Mesechites mansoana & 1 & 1 & 0,0001 & 0,23 & 1,12 & 1,05 & 0,68 & 0,80 \\
Aloysia virgata & 4 & 1 & 0,0000 & 0,94 & 0,30 & 1,05 & 0,62 & 0,76 \\
Anadenanthera macrocarpa & 1 & 1 & 0,0001 & 0,23 & 0,89 & 1,05 & 0,56 & 0,72 \\
Erythroxylum cuneifolium & 1 & 1 & 0,0000 & 0,23 & 0,55 & 1,05 & 0,39 & 0,61 \\
Platyciamus regnellii & 3 & 1 & 0,0000 & 0,70 & 0,06 & 1,05 & 0,38 & 0,60 \\
Banisteriopsis argyrophylla & 1 & 1 & 0,0000 & 0,23 & 0,50 & 1,05 & 0,37 & 0,60 \\
Astronium graveolens & 1 & 1 & 0,0000 & 0,23 & 0,50 & 1,05 & 0,37 & 0,60 \\
Calathea zebrina & 2 & 1 & 0,0000 & 0,47 & 0,24 & 1,05 & 0,36 & 0,59 \\
Siparuna guianensis & 2 & 1 & 0,0000 & 0,47 & 0,24 & 1,05 & 0,36 & 0,59 \\
Palicourea crocea & 2 & 1 & 0,0000 & 0,47 & 0,09 & 1,05 & 0,28 & 0,54 \\
Smilax cissoides & 1 & 1 & 0,0000 & 0,23 & 0,29 & 1,05 & 0,26 & 0,53 \\
Calathea sellowii & 2 & 1 & 0,0000 & 0,47 & 0,03 & 1,05 & 0,25 & 0,52 \\
Cissampelos glaberrima & 2 & 1 & 0,0000 & 0,47 & 0,03 & 1,05 & 0,25 & 0,52 \\
Lacistema floribundum & 1 & 1 & 0,0000 & 0,23 & 0,21 & 1,05 & 0,23 & 0,50 \\
Roupala montana & 1 & 1 & 0,0000 & 0,23 & 0,10 & 1,05 & 0,22 & 0,46 \\
Guettarda viburnoides & 1 & 1 & 0,0000 & 0,23 & 0,06 & 1,05 & 0,17 & 0,45 \\
Rhamnidium eleocarpum & 1 & 1 & 0,0000 & 0,23 & 0,06 & 1,05 & 0,15 & 0,45 \\
Ouratea castaneaefolia & 1 & 1 & 0,0000 & 0,23 & 0,06 & 1,05 & 0,15 & 0,45 \\
Aspidosperma cylindrocarpon & 1 & 1 & 0,0000 & 0,23 & 0,03 & 1,05 & 0,15 & 0,44 \\
\hline
\end{tabular}

\section{Biomassa}

No cerradão, a densidade obtida foi de 11.610 indivíduos lenhosos com diâmetro basal maior que $1 \mathrm{~cm}$ e 120.400 indivíduos lenhosos com diâmetro basal até $0,9 \mathrm{~cm}$ e não-lenhosos por hectare, correspondendo a um volume cilíndrico total de $215,81 \mathrm{~m}^{3}$ e $3,95 \mathrm{~m}^{3}$, respectivamente. Nas duas classes, este volume correspondeu a $219,76 \mathrm{~m}^{3}$ (Tabela 4.11).

Para o cerrado "sensu stricto", a densidade de indivíduos lenhosos com mais de $1 \mathrm{~cm}$ de diâmetro basal foi de 17.175 e a de indivíduos lenhosos com até $0,9 \mathrm{~cm}$ de diâmetro basal e não-lenhosos foi de 159.600 indivíduos por hectare, o que equivaleu a volumes cilíndricos totais de $98,36 \mathrm{~m}^{3}$ e $19,25 \mathrm{~m}^{3}$, ou $117,61 \mathrm{~m}^{3}$ nas duas classes.

Já no campo cerrado, os indivíduos lenhosos com mais de $1 \mathrm{~cm}$ de diâmetro basal foram encontrados em uma densidade de 15.525 e os lenhosos até $0,9 \mathrm{~cm}$ de diâmetro basal e não-lenhosos em densidade de 285.600 indivíduos por hectare. O volume cilíndrico total para esta fisionomia foi 
de $115,01 \mathrm{~m}^{3}$, dos quais $62,20 \mathrm{~m}^{3}$ na primeira classe e $52,81 \mathrm{~m}^{3}$ na segunda.

Na floresta estacional semidecídua, a densidade dos indivíduos lenhosos com mais de $1 \mathrm{~cm}$ de diâmetro basal foi de 18.660 indivíduos por hectare e dos lenhosos até $0,9 \mathrm{~cm}$ de diâmetro basal e não-lenhosos foi de 170.800, com volumes cilíndricos totais correspondendo, pela ordem, a $283,51 \mathrm{~m}^{3}$ e $1,27 \mathrm{~m}^{3}$. Nesta formação, o volume cilíndrico total foi equivalente a $284,78 \mathrm{~m}^{3}$.

A densidade de indivíduos lenhosos com até $0,9 \mathrm{~cm}$ de diâmetro basal e não-lenhosos diminuiu do campo cerrado em direção ao cerradão, com valor intermediário no cerrado "sensu stricto". Na floresta estacional, a densidade foi maior do que no cerrado "sensu stricto" e no cerradão em função do predomínio de Actinostemon communis, que parece se reproduzir vegetativamente. A densidade de indivíduos lenhosos com mais de $1 \mathrm{~cm}$ de diâmetro foi maior no cerrado "sensu stricto", onde predominam arbustos e arvoretas. No campo cerrado, a densidade foi menor, uma vez que os arbustos e arvoretas são mais espaçados. No cerradão, a densidade foi ainda menor do que nas outras duas fisionomias de cerrado, já que há dominância de árvores de maior porte. Na floresta estacional semidecídua, a densidade de indivíduos lenhosos com diâmetro entre 1 e 9,9cm foi muito alta devido, mais uma vez, à abundância de Actinostemon communis. A densidade de indivíduos lenhosos com mais de $10 \mathrm{~cm}$ de diâmetro, por outro lado, foi muito baixa. Como os indivíduos neste componente possuem diâmetros muito grandes, seria esperado, de fato, encontrá-los em menor número. Além disto, as pressões antrópicas a que esta formação foi submetida pode ter contribuído para este baixo valor (Shida em andamento, Capítulo 2).

Castro (1987) afirma que o volume cilíndrico total pode ser usado como um estimador da biomassa, ainda que normalmente resulte em superestimativas. Sendo assim, nas fisionomias amostradas, houve um aumento da biomassa do campo cerrado à floresta estacional semidecídua, passando pelo cerrado "sensu stricto" e pelo cerradão. Este gradiente refletiu-se nos índices de vegetação encontrados na reserva (Mesquita Jr. em andamento, Capítulo 1). 
Tabela 4.11 - Parâmetros gerais das fisionomias amostradas da ARIE Cerrado Pé-de-Gigante, Santa Rita do Passa Quatro, São Paulo $\left(21^{\circ} 36-44^{\prime} \mathrm{S}\right.$ e $\left.47^{\circ} 34-41^{\prime} \mathrm{W}\right)$. Legenda: $\mathrm{n}^{\mathrm{o}}$ spp. = número de espécies, $\mathrm{n}^{\mathrm{o}}$ ind. = número de indivíduos, DT = densidade total (indivíduos/ha), DoTA = dominância total absoluta por área $\left(\mathrm{m}^{2} / \mathrm{ha}\right)$, alt. média = altura média $(\mathrm{m}), \mathrm{VCT}=$ volume cilíndrico total por área $\left(\mathrm{m}^{3} / \mathrm{ha}\right)$.

\begin{tabular}{|c|c|c|c|c|c|c|c|}
\hline fisionomia & critério de inclusão & no. spp. & $\mathrm{n}^{\mathbf{0}}$ ind. & DT & DoTA & alt. média & VCT \\
\hline \multirow{4}{*}{ cerradão } & lenhosos com mais de $10 \mathrm{~cm}$ & 42 & 365 & 1460 & 29,43 & 5,84 & 174,79 \\
\hline & lenhosos entre 1 e $9,9 \mathrm{~cm}$ & 70 & 406 & 10150 & 16,95 & 2,42 & 41,02 \\
\hline & lenhosos até $0,9 \mathrm{~cm}$ e não-lenhosos & 65 & 301 & $\begin{array}{c}12040 \\
0\end{array}$ & 9,63 & 0,41 & 3,95 \\
\hline & total & 110 & 1072 & $\begin{array}{c}13201 \\
0\end{array}$ & 56,01 & - & 219,76 \\
\hline \multirow{3}{*}{ cerrado "sensu stricto" } & lenhosos com mais de $1 \mathrm{~cm}$ & 84 & 687 & 17175 & 49,93 & 1,97 & 98,36 \\
\hline & lenhosos até $0,9 \mathrm{~cm}$ e não-lenhosos & 81 & 399 & $\begin{array}{c}15960 \\
0\end{array}$ & 52,03 & 0,37 & 19,25 \\
\hline & total & 117 & 1086 & $\begin{array}{c}17677 \\
5 \\
\end{array}$ & 101,96 & - & 117,61 \\
\hline \multirow{3}{*}{ campo cerrado } & lenhosos com mais de $1 \mathrm{~cm}$ & 87 & 621 & 15525 & 48,98 & 1,27 & 62,20 \\
\hline & lenhosos até $0,9 \mathrm{~cm}$ e não-lenhosos & 81 & 714 & $\begin{array}{c}28560 \\
0\end{array}$ & 128,81 & 0,41 & 52,81 \\
\hline & total & 130 & 1335 & $\begin{array}{c}30112 \\
5 \\
\end{array}$ & 177,79 & - & 115,01 \\
\hline \multirow{4}{*}{ floresta estacional } & lenhosos com mais de $10 \mathrm{~cm}$ & 38 & 140 & 560 & 25,07 & 9,90 & 248,20 \\
\hline & lenhosos entre 1 e $9,9 \mathrm{~cm}$ & 68 & 724 & 18100 & 11,89 & 2,97 & 35,31 \\
\hline & lenhosos até $0,9 \mathrm{~cm}$ e não-lenhosos & 43 & 427 & $\begin{array}{c}17080 \\
0\end{array}$ & 2,39 & 0,53 & 1,27 \\
\hline & total & 87 & 1291 & $\begin{array}{c}18946 \\
0 \\
\end{array}$ & 39,95 & - & 284,78 \\
\hline
\end{tabular}

\section{Diversidade}

Para o conjunto dos componentes, no cerradão, os índice de diversidade (H') e de equabilidade (J) foram de 3,901 nat/ind e 0,830, respectivamente. Estes índices equivaleram a 4,022 nat/ind e 0,844, para o cerrado "sensu stricto" e a 4,015 nat/ind e 0,825 , para o campo cerrado. A floresta estacional apresentou valores mais baixos, com índice de diversidade (H') igual a 3,017 nat/ind e de equabilidade (J) equivalente a 0,675 (Tabela 4.12). No cerradão, o componente intermediário apresentou valores de riqueza e diversidade mais altos que os do componente dominante, pois o primeiro componente conteve não só espécies próprias como também espécies do segundo. O número de indivíduos amostrados em cada componente contribuiu para a riqueza encontrada e, 
conseqüentemente, para a diversidade. Assim, por exemplo, o pequeno número de indíviduos amostrados no componente dominante da floresta estacional contribuiu para diminuir sua diversidade.

O índice de diversidade de Shannon refere-se à estrutura da comunidade e mostra a diversidade dentro de uma comunidade considerada homogênea (Mantovani 1996). Este tipo de diversidade intra-habitats é chamada de diversidade $\alpha$ (Whittaker 1977).

Os índices de diversidade encontrados para as fisionomias de cerrado são relativamente altos, quando comparados com outras áreas de cerrado e até com outras formações (Mantovani 1996). A amostragem aqui realizada, em que foram incluídos não só os indivíduos lenhosos como também os não-lenhosos, contribuiu para aumentar a diversidade destas três fisionomias. Castro (1994) comentou que a afirmação feita por vários autores de que o cerrado possui baixa diversidade e riqueza é decorrente de estudos apenas no seu componente arbustivo-arbóreo.

A floresta estacional, por outro lado, apresentou baixa diversidade se comparada com outras áreas com o mesmo tipo de cobertura vegetal (Pagano \& Leitão-Filho 1987, Rodrigues et al. 1989, Cesar \& Leitão-Filho 1990), onde, apenas para o componente dominante, os valores do índice de Shannon variaram de 3,56 a 4,29 nat/ind. Na ARIE Cerrado Pé-de-Gigante, esta mancha de floresta foi submetida recentemente a intenso corte de madeira, o que provavelmente diminuiu sua diversidade (Shida em andamento, Capítulo 2). Esta baixa diversidade é mais nítida nas classes que incluíram os indivíduos lenhosos entre 1 e 9,9cm $\left(\mathrm{H}^{\prime}=2,822\right.$ nat/ind) e os lenhosos até $0,9 \mathrm{~cm}$ e nãolenhosos ( $\left.\mathrm{H}^{\prime}=2,221\right)$, em que houve amplo predomínio de Actinostemon communis.

Segundo Whittaker (1977), as mudanças ao longo de um gradiente ambiental ou entre diferentes comunidades de uma paisagem determinam a diversidade $\beta$, ou diversidade inter-habitats. Uma das maneiras de se medir a diversidade $\beta$ é através de índices de similaridade (Mantovani 1996), como os de Sørensen (1948) e de Bray-Curtis (Bray \& Curtis 1957). O índice de Sørensen é utilizado para 
comparação qualitativa entre comunidades, enquanto que o índice de Bray-Curtis é uma modificação quantitativa do índice de Sørensen (Mueller-Dombois \& Ellenberg 1974).

A Figura 4.2 mostra que embora as três fisionomias de cerrado possam ser consideradas similares qualitativamente, refletindo a unidade florística desta formação, com valores maiores que 0,5 para o índice de Sørensen, elas não o são quando comparadas quantitativamente pelo índice de BrayCurtis. Estes resultados mostram que o cerrado da ARIE Pé-de-Gigante não só tem alta diversidade $\alpha$ como também alta diversidade $\beta$.

A comparação da estrutura das fisionomias de cerrado da ARIE Pé-de-Gigante com a de outras áreas de cerrado próximas, em Corumbataí (Pagano et al. 1989) e Pirassununga (Vincent et al. 1992), ressaltou também a alta heterogeneidade regional do cerrado, ou diversidade $\gamma$ (Whittaker 1977).

Tabela 4.12 - Índices ecológicos das fisionomias amostradas da ARIE Cerrado Pé-de-Gigante, Santa Rita do Passa Quatro, São Paulo (2136-44'S e 47³4-41'W). Legenda: H' = índice de diversidade de Shannon (nat/ind), E = índice de equabilidade de Pielou.

\begin{tabular}{ccccc}
\hline fisionomia & critério de inclusão & $\mathbf{n}^{\mathbf{0}}$ spp. & H' & $\mathbf{E}$ \\
\hline \hline \multirow{2}{*}{ cerradão } & lenhosos com mais de 10cm & 42 & 3,147 & 0,842 \\
& lenhosos entre 1 e 9,9cm & 70 & 3,550 & 0,836 \\
& lenhosos até 0,9cm e não-lenhosos & 65 & 3,477 & 0,833 \\
& total & 110 & 3,901 & 0,830 \\
\hline \multirow{3}{*}{ cerrado "sensu stricto"” } & lenhosos com mais de 1cm & 84 & 3,707 & 0,837 \\
& lenhosos até 0,9cm e não-lenhosos & 81 & 3,550 & 0,808 \\
& total & 117 & 4,022 & 0,844 \\
\hline campo cerrado & lenhosos com mais de 1cm & 87 & 3,743 & 0,838 \\
& lenhosos até 0,9cm e não-lenhosos & 81 & 3,446 & 0,784 \\
& total & 130 & 4,015 & 0,825 \\
\hline \multirow{3}{*}{ floresta estacional } & lenhosos com mais de 10cm & 38 & 3,160 & 0,869 \\
& lenhosos entre 1 e 9,9cm & 68 & 2,822 & 0,669 \\
& lenhosos até 0,9cm e não-lenhosos & 43 & 2,221 & 0,590 \\
& total & 87 & 3,017 & 0,675 \\
\hline
\end{tabular}



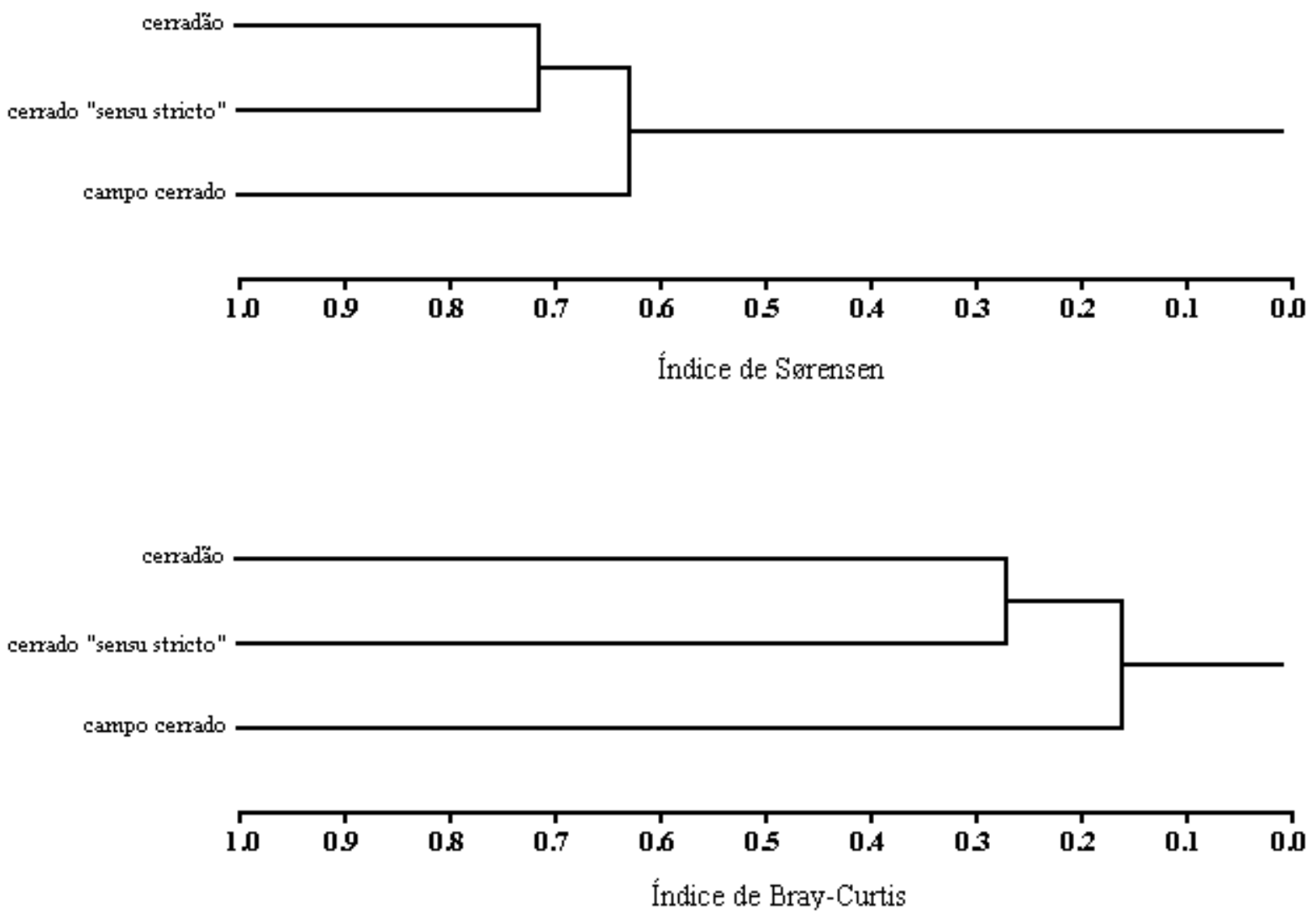

Figura 4.2 - Dendrogramas de similaridade entre três fisionomias de cerrado na ARIE Cerrado Pé-de-Gigante, Santa Rita do Passa Quatro, São Paulo (21³6-44'S e 47³4-41'W), de acordo com os índices de Sørensen e de Bray-Curtis.

\section{Conclusões}

No cerradão, as espécies com maiores valores de importância foram: Anadenanthera falcata, Pterodon pubescens, Copaifera langsdorfii, Pouteria ramiflora e Xylopia aromatica, entre os indivíduos lenhosos com mais de $10 \mathrm{~cm}$ de diâmetro do caule no nível do solo; Myrcia lingua, Xylopia aromatica, Virola sebifera, Dyptichandra aurantiaca e Pouteria ramiflora, entre os indivíduos lenhosos com 1 a 9,9cm de diâmetro basal; e Rhynchospora exaltata, Myrcia lingua, Loudetiopsis chrysothrix, Styrax ferrugineus e Memora peregrine, entre os indivíduos lenhosos com até $0,9 \mathrm{~cm}$ de diâmetro basal e os não-lenhosos. 
No cerrado "sensu stricto", Myrcia lingua, Xylopia aromatica, Dyptichandra aurantiaca, Miconia albicans e Anadenanthera falcata foram as espécies mais importantes para os indivíduos lenhosos com mais de $1 \mathrm{~cm}$ de diâmetro do caule no nível do solo; e Rhynchospora exaltata, Loudetiopsis chrysothrix, Axonopus marginatus, Byrsonima intermedia e Ichnanthus sericeus para os indivíduos lenhosos com até $0,9 \mathrm{~cm}$ de diâmetro basal e os não-lenhosos.

No campo cerrado, entre os indivíduos lenhosos com mais de $1 \mathrm{~cm}$ de diâmetro do caule no nível do solo, Pouteria torta, Anadenanthera falcata, Miconia albicans, Byrsonima intermedia e Ouratea spectabilis foram as espécies mais importantes. Já para os lenhosos com até $0,9 \mathrm{~cm}$ de diâmetro basal e os não-lenhosos, as espécies que se destacaram foram Loudetiopsis chrysothrix, Axonopus marginatus, Melinis minutiflora, Axonopus barbigerus e Byrsonima intermedia.

$\mathrm{Na}$ floresta estacional semidecídua, as espécies mais importantes foram: Platypodium elegans, Croton floribundus, Tabebuia serratifolia, Machaerium villosum e Anadenanthera macrocarpa, entre os indivíduos lenhosos com mais de $10 \mathrm{~cm}$ de diâmetro do caule no nível do solo; Actinostemon communis, Esenbeckia febrifuga, Cupania vernalis, Croton floribundus e Casearia grandiflora, entre os indivíduos lenhosos com 1 a 9,9cm de diâmetro basal; e Actinostemon communis, Hybanthus atropurpureus, Olyra micrantha, Psychotria barbiflora e Cupania vernalis, entre os indivíduos lenhosos com até $0,9 \mathrm{~cm}$ de diâmetro basal e os não-lenhosos.

A biomassa, estimada pelo volume cilíndrico total, aumentou do campo cerrado à floresta estacional semidecídua, com valores intermediários no cerrado "sensu stricto" e no cerradão.

O cerrado, em suas três fisionomias, apresentou não só grande diversidade $\alpha$, como também altas diversidades $\beta$ e $\gamma$. Mesmo entre amostras na mesma fisionomia, o valor de similaridade foi baixo, refletindo a grande heterogeneidade do cerrado, que deve ter implicações para a fauna associada à reserva. A floresta estacional, por sua vez, apresentou baixa diversidade $\alpha$, em função das perturbarções a que foi submetida recentemente, notadamente o corte seletivo de madeira. 


\section{Referências bibliográficas}

BATISTA, E. A. 1982. Levantamentos fitossociológicos aplicados à vegetação do cerrado utilizando-se de fotografias aéreas verticais. Tese de Mestrado. Esc. Sup. Agri. "Luiz de Queiroz".

BRAY, J. R. \& CURTIS, C. T. 1957. An ordination of the upland forest communities of southeastern Wisconsin. Ecol. Monogr. 27: 325-49.

CASTRO, A. A. J. F. 1987. Florística e fitossociologia de um cerrado marginal brasileiro, Parque Estadual de Vassununga, Santa Rita do Passa-Quatro, SP. Tese de Mestrado. Univ. Est. Campinas.

CASTRO, A. A. J. F. 1994. Comparação florístico-geográfica (Brasil) e fitossociológica (Piauí São Paulo) de amostras de cerrado. Tese de Doutorado. Univ. Fed. Piauí.

CATHARINO, E. R. M. 1989. Estudos fisionômicos-florísticos e fitossociológico em matas residuais secundárias do município de Piracicaba, SP. Tese de Mestrado. Univ. Est. Campinas.

CAVASSAN, O. 1990. Florística e fitossociologia da vegetação lenhosa em um hectare de cerrado no Parque Ecológico Municipal de Bauru (SP). Tese de Doutorado. Univ. Est. Campinas.

CAVASSAN, O.; CESAR, O. \& MARTINS, F. R. 1984. Fitossociologia da vegetação arbórea da Reserva Estadual de Bauru, estado de São Paulo. Revta. Bras. Bot. 7: 91-106.

CESAR, O. \& LEITÃO-FILHO, H. de F. 1990. Estudo fitossociológico da mata mesófila semidecídua da Fazenda Barreiro Rico, município de Anhembi, SP. Revta. Bras. Biol. 50(2): 443-52.

CESAR, O.; PAGANO, S. N.; LEITÃO-FILHO, H. de; MONTEIRO, R.; SILVA, O. A.; MARTINS, 
G. de \& SHEPHERD, G. J. 1988. Estrutura fitossociológica do estrato arbóreo de uma área de vegetação de cerrado no município de Corumbataí (SP). Naturalia 13: 91-101.

CHIARINI, J. V. \& COELHO, A. G. S. 1972. Cobertura vegetal e natural e áreas reflorestadas do estado de São Paulo. Bol. Inst. Agr. Camp. 193.

EITEN, G. 1970. A vegetação do estado de São Paulo. Bolm. Inst. Bot. S. Paulo 7: 1-147.

FELFILI, J. M.; FILGUEIRAS, T. de S.; HARIDASSAN, M.; SILVA JÚNIOR, M. C. de; MENDONÇA, R. C. de \& REZENDE, A. V. 1994. Projeto bioeografia do bioma cerrado: vegetação \& solos. Cad. Geoc. 12: 75-166.

GABRIEL, J. L. C. 1990. Composição florística e estrutura fitossociológica do estrato arbóreo de mata mesófila semidecídua de encosta no município de Botucatu, SP. Tese de Mestrado. Univ. Est. S. Paulo.

GANDOLFI, S. 1991. Estudo florístico e fitossociológico de uma floresta residual na área do Aeroporto Internacional de Guarulhos, SP. Tese de Mestrado. Univ. Est. Campinas.

GIANOTTI, E. 1988. Composição florística e estrutura fitossociológica da vegetação de cerrado e de transição entre cerrado e mata ciliar da Estação Experimental de Itirapina (SP). Tese de Mestrado. Univ. Est. Campinas.

GOODLAND, R. 1969. Análise ecológica da vegetação do cerrado. In: FERRI, M. G. \& GOODLAND, R. 1979. Ecologia do cerrado. Belo Horizonte, Itatiaia; São Paulo, EDUSP.

INSTITUTO FLORESTAL. 1993. Inventário florestal do estado de São Paulo. São Paulo, Secretaria do Meio Ambiente.

KOTCHETKOFF-HENDRIQUES, O. \& JOLY, C. A. 1994. Estudo florístico e fitossociológico em uma mata mesófila semidecídua na Serra do Itaqueri, Itirapina, estado de São Paulo. Revta. Bras. Biol. 54(3): 477-87.

MANTOVANI, W. 1987. Análise florística e fitossociológica do estrato herbáceo-subarbustivo 
do cerrado na reserva biológica de Moji Guaçu e em Itirapina, SP. Tese de Doutorado. Univ. Est. Campinas.

MANTOVANI, W. 1996. Methods for assessment of terrestrial phanerogams biodiversity. In: BICUDO, C. E. M. \& MENEZES, N. A. Biodiversity in Brazil: a first approach. São Paulo, CNPq.

MANTOVANI, W., LEITÃO, G.F. \& MARTINS, F.R. 1985. Chave baseada em caracteres vegetativos para a identificação de espécies lenhosas do cerrado da Reserva Biológica de Moji Guaçu, Estado de São Paulo. Hoehnea 12: 35-56.

MANTOVANI, W. \& MARTINS, F. R. 1993. Florística do cerrado na reserva biológica de Moji Guaçu, SP. Acta Bot. Bras. 7: 33-60.

MARTINS, F. R. 1991. Estrutura de uma floresta mesófila. Campinas, Univ. Est. Campinas.

MATTHES, L. A. F.; LEITÃO-FILHO, H. de F. \& MARTINS, F. R.1988. Bosque dos Jequitibás (Campinas, SP): composição florística e estrutura fitossociológica do estrato arbóreo. In: CONGR. SBSP 5. Anais. Soc. Bot. S. Paulo, p.55-76.

MEIRA NETO, J. A. A. 1991. Composição florística e estrutura fitossociológica de fisionomias de cerrado "sensu lato" da Estação Ecológica de Santa Bárbara - Município de Águas de Santa Bárbara - Estado de São Paulo. Tese de Mestrado. Univ. Est. Campinas.

MESQUITA JR., H. N. de. Em andamento. Identificação de fisionomias de cerrado com imagem índice de vegetação. São Paulo. Dissertação de Mestrado. Univ. S. Paulo.

MUELLER-DOMBOIS, D. \& ELLENBERG, H. 1974. Aims and methods of vegetation ecology. New York, John Willey \& Sons.

NASCIMENTO, M. T. \& SADDI, N. 1992. Structure and floristic composition in an area of cerrado in Cuiabá - MT, Brazil. Revta. Bras. Bot. 15(1): 47-55.

NICOLINI, E. M. 1990. Composição florística e estrutura fitossociológica do estrato arbóreo em 
mata mesófila semidecídua no município de Jahu, SP. Tese de Mestrado. Univ. Est. S. Paulo.

OLIVEIRA E SOUZA, M. H. A. de. 1977. Alguns aspectos ecológicos da vegetação na Represa do Lobo (Brotas - Itirapina, SP). Tese de Doutorado. Univ. S. Paulo.

OLIVEIRA FILHO, A. T. 1984. Estudo florístico e fitossociológico em um cerrado na Chapada dos Guimarães - Mato Grosso - uma análise de gradientes. Tese de Mestrado. Univ. Est. Campinas.

PAGANO, S. N.; CESAR, O. \& LEITÃO-FILHO, H. de. 1989. Estrutura fitossociológica do estrato arbustivo-arbóreo da vegetação de cerrado da Área de Proteção Ambiental (APA) de Corumbataí, SP. Revta. Bras. Biol. 49: 49-59.

PAGANO, S. N. \& LEITÃO-FILHO, H. de F. 1987. Estudo fitossociológico em mata mesófila semidecídua no município de Rio Claro (estado de São Paulo). Revta. Bras. Bot. 10: 49-62.

PAGANO, S. N.; LEITÃO-FILHO, H. de F. \& CAVASSAN, O. 1995. Variação temporal da composição florística e estrutura fitossociológica de uma floresta mesófila semidecídua - Rio Claro - estado de São Paulo. Rev. Bras. Biol. 55(2): 241-58.

PICOLLO, A. L. G.; THOMAZINI, L. I.; MASSA, C. S.; CESAR, O.; PAGANO, S. N.; MORAES, A. P. V. \& AMARAL, H. 1971. Aspecto fitossociológico de uma reserva de cerrado. Revta. Agric. 46: 81-92.

PIELOU, E. C. 1975. Ecological diversity. New York, John Willey \& Sons.

PINTO, M. M. 1989. Levantamento fitossociológico de uma mata residual: campus de Jaboticabal da UNESP. Tese de Mestrado. Univ. Est. S. Paulo.

RATTER, J. A. 1992. Transitions between cerrado and forest vegetation in Brazil. In: FURLEY, P. A.; PROCTOR, J. \& RATTER, J. A. (ed). Dynamics of forest-savanna boundaries. London, Chapman \& Hall.

RIBEIRO, J. F, SILVA, J. C. S \& BATMANIAN, G. J. 1985. Fitossociologia de tipos fisionômicos 
de cerrado em Planaltina, D.F. Revta. Bras. Bot. 8(2): 131-42.

RODRIGUES, R. R.; MORELlatO, L. P. C.; JOLY, C. A. \& LEITÃO-FILHO, H. de F. 1989. Estudo florístico e fitossociológico em um gradiente altitudinal de mata estacional mesófila semidecídua, na Serra do Japi, Jundiaí, SP. Rev. Bras. Bot. 12: 71-84.

SALIS, S. M.; SHEPHERD, G. J. \& JOLY, C. A. 1995. Floristic comparison of mesophytic semidecidous forests of the interior of the state of São Paulo, Southeast Brazil. Vegetatio 119: $155-64$.

SHANNON, C. E. \& WEAVER, W. 1963. The mathematical theory of communication. Urbana, Univ. Illinois.

SHEPHERD, G. J. 1994. Fitopac 1, manual do usuário. Campinas, Depto. Botânica Univ. Est. Campinas.

SHIDA, C. N. Em andamento. A ocupação humana no entorno da ARIE Cerrado Pé-de-Gigante (Santa Rita do Passa Quatro, SP) e sua influência sobre os ecossitemas naturais. Dissertação de Mestrado. Univ. S. Paulo.

SILVA, A. F. 1989. Composição florística e estrutura fitossociológica do estrato arbóreo da Reserva Florestal Professor Augusto Ruschi, São José dos Campos. Tese de Mestrado. Univ. Est. Campinas.

SØRENSEN, T. 1948. A method of establishing groups of equal amplitude in plant society based on similarity of species content. K. Danske Vidensk. Selsk. 5: 1-34.

SPELLERBERG, I. F. 1992. Evaluation and assessment for conservation. London, Chapman \& Hall.

TOLEDO FILHO, D. V. 1984. Composição florística e estrutura fitossociológica da vegetação de cerrado no município de Luiz Antônio (SP). Tese de Mestrado. Univ. Est. Campinas.

VElOSO, H. P.; RANGEL FILHO, A. L. R. \& LIMA, J. C. A. 1991. Classificação da vegetação 
brasileira adaptada a um sistema universal. Rio de Janeiro, IBGE.

VINCENT, R. de C., MIYAZAKI, S.L., GOMES, E.P.C. \& MANTOVANI, W. 1992. Estrutura e composição florística do cerrado de Emas, Pirassununga, SP. In: CONGR. SBSP 8, Campinas, 1990. Anais. Soc. Bot. S. Paulo, p.139-151.

WHITTAKER, R. H. 1977. Evolution of species diversity in land communities. In: HECHT, M. K., STEERE, W. C. \& WALLACE, B. (eds). Evolutionary biology. New York, Plenum Press. 


\section{Anexo - Formulário}

Parâmetros fitossociológicos (Mueller-Dombois \& Ellenberg 1974)

- densidade absoluta (DA) $=\mathrm{n}_{\mathrm{e}} \cdot \mathrm{U} / \mathrm{A}$ (indivíduos/hectare)

- $\quad$ densidade relativa $(\mathrm{DR})=100 . \mathrm{n}_{\mathrm{e}} / \mathrm{N}(\%)$

- ocorrência $(\mathrm{Oc})=\mathrm{P}_{\mathrm{e}} / \mathrm{P}$

- frequiência relativa $(\mathrm{FR})=100.0 \mathrm{c}_{\mathrm{e}} / \Sigma \mathrm{Oc}(\%)$

- dominância absoluta $(\mathrm{DoA})=\mathrm{AB}_{\mathrm{e}} \cdot \mathrm{U} / \mathrm{A}\left(\mathrm{m}^{2} /\right.$ hectare $)$

- $\operatorname{dominância~relativa~}(\mathrm{DoR})=100 . \mathrm{AB}_{\mathrm{e}} / \mathrm{ABT}(\%)$

- $\quad$ valor de cobertura $(\mathrm{VC})=(\mathrm{DR}+\mathrm{DoR}) / 2(\%)$

- $\quad$ valor de importância $(\mathrm{VI})=(\mathrm{DR}+\mathrm{FR}+\mathrm{DoR}) / 3(\%)$,

onde $\mathrm{n}_{\mathrm{e}}=$ número de indivíduos da espécie $e ; \mathrm{U}=$ unidade de área (1ha); $\mathrm{A}=$ área amostrada; $\mathrm{N}=$ número total de indivíduos; $\mathrm{P}_{\mathrm{e}}=$ número de parcelas com ocorrência da espécie $e ; \mathrm{P}=$ número total de parcelas; $\mathrm{Oc}_{\mathrm{e}}=$ ocorrência da espécie $e ; \Sigma \mathrm{Oc}=$ somatória de todas ocorrências; $\mathrm{AB}_{\mathrm{e}}=$ área basal da espécie $e ; \mathrm{ABT}=$ área basal total.

Biomassa (Castro 1987)

- $\quad$ volume cilíndrico total $(\mathrm{VCT})=\mathrm{ABT} \cdot \mathrm{AT}_{\text {média }}\left(\mathrm{m}^{3} / \mathrm{ha}\right)$,

onde $\mathrm{ABT}=$ área basal total por hectare; $\mathrm{AT}_{\text {média }}=$ altura total média.

Índices de diversidade e equabilidade (Mantovani 1996)

- $\quad$ índice de diversidade de Shannon $\left(H^{\prime}\right)=-\Sigma p_{\mathrm{i}} \ln \mathrm{p}_{\mathrm{i}}$ (nat/indivíduo)

- $\quad$ índice de equabilidade de Pielou $(J)=H^{\prime} / \ln S$,

onde $\mathrm{p}_{\mathrm{i}}=$ proporção de indivíduos na iésima espécie; $\mathrm{S}=$ número de espécies.

Índices de similaridade (Mantovani 1996)

- $\quad$ índice de Sørensen $(S)=2 c / a+b$

- índice de Bray-Curtis $(\mathrm{BC})=\Sigma$ mínimo $\mathrm{p}_{\mathrm{i}}$ comum,

onde $\mathrm{c}=$ número de espécies em comum; $\mathrm{a}=$ número de espécies na área $\mathrm{A} ; \mathrm{b}=$ número de espécies na área $\mathrm{B} ; \mathrm{p}_{\mathrm{i}}=$ proporção de indivíduos na iésima espécie. 


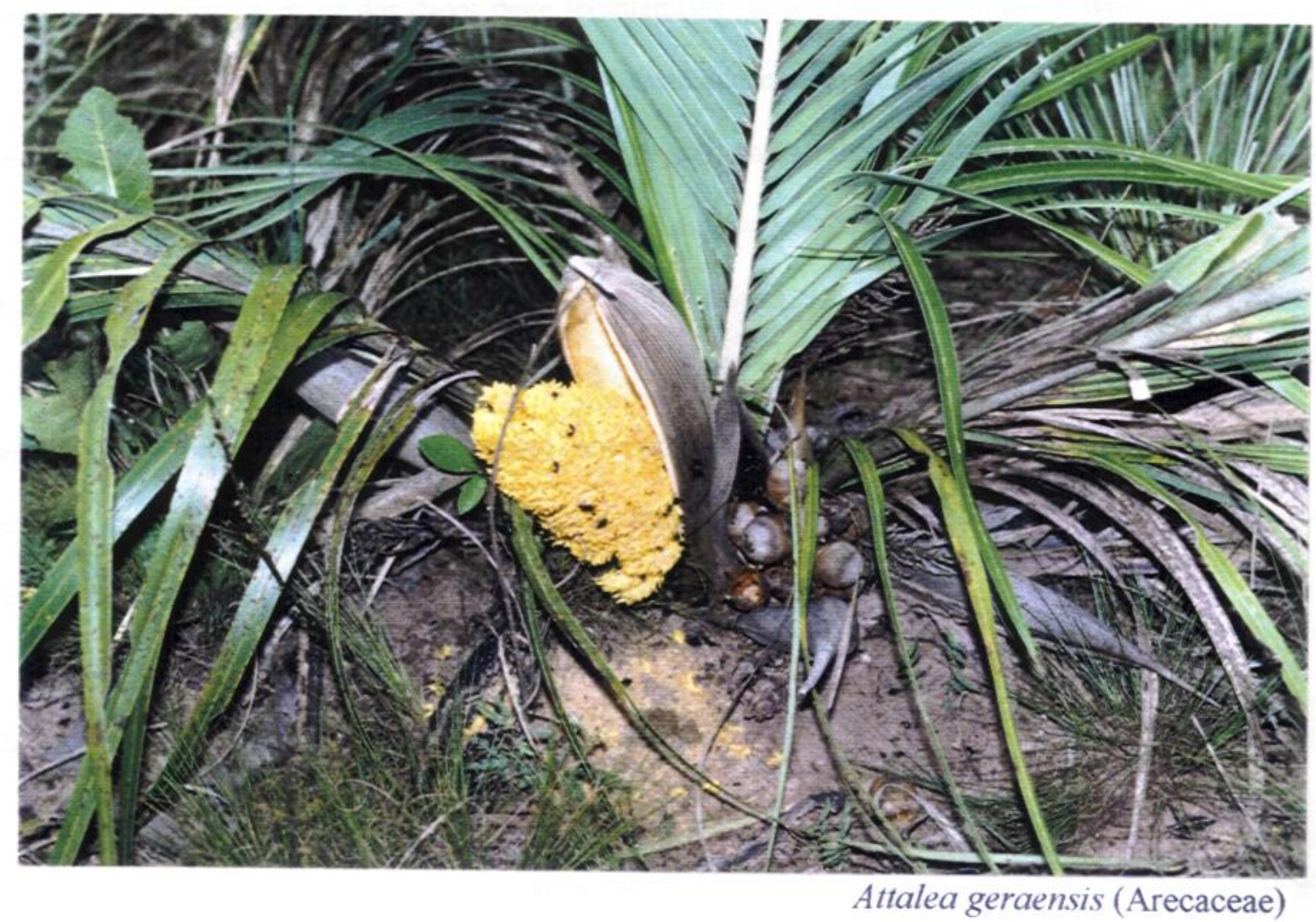




\section{Padrões fenológicos das espécies de cerrado "sensu lato" da ARIE Cerrado Pé-de- Gigante (Santa Rita do Passa Quatro, SP).}

Resumo - Foi estudada uma área marginal de vegetação natural, composta principalmente por cerrado, de 1269ha, situada no munícipio de Santa Rita do Passa Quatro, estado de São Paulo (21³6-44’S e 47³4-41’W). Entre setembro de 1995 e fevereiro de 1997, realizou-se um levantamento florístico, em que foram amostradas 360 espécies nas fisionomias de cerrado. A partir dos dados deste levantamento, estudaram-se as variações fenológicas das espécies, procurando analisá-las como estratégias adaptativas. A deciduidade foliar iniciou-se em julho, atingindo seu máximo em agosto, enquanto que o brotamento se deu a partir de outubro. A proporção de espécies anemo e autocóricas foi maior no componente herbáceo-subarbustivo, ao contrário das zoocóricas, mais freqüentes no componente arbustivo-arbóreo. As espécies arbustivo-arbóreas floresceram principalmente no início da estação chuvosa, enquanto que as herbáceosubarbustivas produziram flores, de modo geral, apenas no final da estação úmida, após período de acúmulo de carboidratos. A proporção de espécies anemo e autocóricas em frutificação foi maior na estação seca, quando sua dispersão é mais eficiente. Já as espécies zoocóricas frutificaram principalmente durante toda a estação quente e chuvosa, quando seus frutos carnosos podem se manter atraentes por mais tempo.

Palvras-chave: cerrado, savana, fenologia, Pé-de-Gigante

Abstract - A natural vegetation area, composed mainly by cerrado, with 1269 ha, located at Santa Rita do Passa

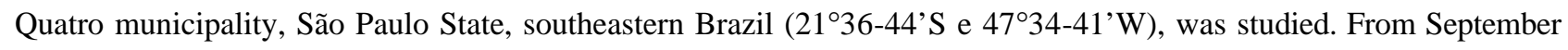
1995 to February 1997, a floristic survey was carried out, in which 360 species were found in three cerrado physiognomies. During this survey, the phenological variations were observed and analysed as adaptive strategies. Leaf fall began in july, reaching its peak in August, while flushing started in October. The ratio of anemo and autochorous species was greater in the herbaceous component. The zoochorous ones, on the other hand, were more frequent in the woody component. The woody species flowered mainly at the beginning of the rainy season, while the herbaceous ones produced flowers generally at the end of that season, after a period of carbohydrate accumulation. The anemo and autochorous species produced fruits principally at the dry season, when its dispersion is more efficient. The zoochorous ones fruited along the whole rainy and warm season, when its fruits become attractive for longer time. 
Key words: cerrado, savanna, phenology, southeastern Brazil

\section{Introdução}

As espécies de cerrado, como aquelas de outras formações estacionais, apresentam variações sazonais quanto à produção de folhas, flores e frutos, que representam adaptações a fatores bióticos ou abióticos (Schaik et al. 1993), determinadas por características genéticas de cada espécie (Salisbury \& Ross 1992). Estas adaptações são estruturais e funcionais (Rachid 1947, RachidEdwards 1956, Labouriau 1963, Rizzo et al. 1971, Barradas 1972, Rizzini 1976, Barros \& Caldas 1980, Coutinho 1980 e Figueiredo \& Dietrich 1981), podendo ser vegetativas ou reprodutivas (Rizzini 1976). Tais adaptações podem ser estudadas pela fenologia, analisando-se o periodismo da vegetação.

Lieth (1974) define fenologia como o estudo da ocorrência de eventos biológicos, a influência dos fatores bióticos ou abióticos nestes eventos e as relações entre as fenofases de espécies diferentes ou de uma única espécie. Rathcke \& Lacey (1985) a definem como o estudo do tempo de ocorrência dos eventos do ciclo de vida. Estes eventos estão relacionados a um ou mais fatores ecológicos e representam estratégias adaptativas que possibilitam a determinada população a superação de um problema (Martins 1982, Rathcke \& Lacey 1985).

O estudo dos padrões fenológicos é importante para a compreensão da dinâmica de comunidades vegetais (Fournier 1969) e, conseqüentemente, para o manejo da flora (Ribeiro \& Castro 1986).

Este trabalho tem como objetivo analisar a fenologia das populações de plantas das fisionomias de cerrado da ARIE Cerrado Pé-de-Gigante, procurando entender os seus diferentes padrões como estratégias adaptativas. Propõe-se discutir as variações fenológicas tanto do componente herbáceo- 
subarbustivo quanto do arbustivo-arbóreo, relacionando-as com as síndromes de dispersão dos diásporos. Com isto, espera-se também fornecer subsídios ao plano de manejo da área estudada, permitindo a compreensão de sua dinâmica e de suas interrelações locais e regionais.

\section{Material e métodos}

\section{Área de estudo}

A Área de Relevante Interesse Ecólogico (ARIE) Cerrado Pé-de-Gigante está localizada no município de Santa Rita do Passa Quatro, estado de São Paulo, entre as coordenadas 21³6-44'S e 47³4-41'W, sob clima Cwag' de Köppen, em cotas altimétricas de 660 a 730m e sobre latossolo Vermelho-Amarelo fase arenosa (Castro 1987). A área estudada possui 1269ha, dos quais 1060ha constituem a ARIE Cerrado Pé-de-Gigante. Em seu interior, existem variações fisionômicas de cerrado que vão desde o campo sujo ao cerradão, além de mata ciliar, floresta estacional semidecídua e campo de várzea. Para uma caracterização mais detalhada da área, ver o Capítulo 1.

\section{Metodologia}

As variações fenológicas das espécies de cerrado foram estudadas a partir dos dados encontrados no levantamento florístico realizado entre setembro de 1995 e fevereiro de 1997 (Capítulo 2), quando, em 18 excursões de coleta mensais, foram amostradas, no cerrado "sensu lato", 360 espécies, pertencentes a 234 gêneros e 78 famílias.

As espécies com material fértil foram analisadas quanto ao seu estado fenológico reprodutivo: floração e/ou frutificação ou formação de esporos. Durante as excursões, foram anotadas ainda 
informações sobre a abscisão foliar, a morte dos ramos de brotamento e dos indivíduos de espécies anuais, a dormência e o brotamento das gemas, a produção de flores e/ou frutos e as formas de vida dos indivíduos. Tais informações foram comparadas com dados climáticos coletados entre 1986 e 1995, na estação meteorológica de Santa Rita do Passa Quatro (2143’09'’S e 47²8’22’’W).

As variações fenológicas foram analisadas separadamente como adaptações vegetativas e reprodutivas. As observações sobre as adaptações vegetativas referem-se, de modo geral, à vegetação como um todo e não a uma determinada espécie.

A análise fenológica foi realizada separadamente para os componentes herbáceo-subarbustivo e arbustivo-arbóreo, associando-a às síndromes de dispersão e, deste modo, procurando entender as variações fenológicas como estratégias adaptativas (Mantovani \& Martins 1988).

As espécies foram classificadas quanto às formas de vida segundo o conceito de Raunkiaer (1934). As síndromes de dispersão foram analisadas de acordo com Pijl (1972) e Ridley (1930). A análise das variações fenológicas seguiu a metodologia de Mantovani \& Martins (1988).

\section{Resultados e discussão}

\section{Adaptações vegetativas}

Como adaptações vegetativas foram consideradas a abscisão foliar, a morte de ramos de brotamento e de indivíduos de espécies anuais, a dormência das gemas e o brotamento.

A deciduidade foliar e a morte dos ramos de brotamento e de indivíduos das espécies anuais tornaram-se evidentes a partir de junho, atingindo seu máximo em agosto. A cobertura vegetal, em seus diferentes estratos, alcançou seu mínimo em setembro. Este período está compreendido naquele mais seco do ano, que vai do fim de junho ao início de setembro, quando, 
concomitantemente à diminuição de pluviosidade e da temperatura média mensal (Figura 5.1), há queda na umidade relativa média mensal (Martins 1982) e no comprimento do dia (Grise 1971). Estes resultados estão de acordo com aqueles obtidos em Goiânia por Rizzo et al. (1971), em Brasília por Barros \& Caldas (1980) e Morais et al. (1995), em Mogi-Guaçu por Mantovani \& Martins (1988), em Cuiabá por Nascimento et al. (1990), em Alter-do-Chão por Miranda (1995) e em Pirassununga por Batalha et al. (no prelo).

A queda das folhas é estimulada, além da sua própria idade, por fatores ambientais, principalmente a seca e a deficiência de nitrogênio (Salisbury \& Ross 1992, Mohr \& Schopfer 1995). A abscisão foliar seria uma adaptação vegetativa contra a perda de água, nutrientes e carbono (Rizzini 1979, Kikuzawa 1995, Mohr \& Schopfer 1995), permitindo a sobrevivência do indivíduo em condições desfavoráveis. Os nutrientes das folhas, principalmente nitrogênio e fósforo, são translocados destas para outros orgãos, aumentando não só as possibilidades de sobrevivência das plantas perenes como sua produtividade (White 1972, Gerloff 1976, Bloom et al. 1985, Thornton \& Millard 1993).

Nascimento et al. (1990) estudaram a herbivoria e a longevidade foliar em duas espécies de cerrado e concluíram que estes dois parâmetros não estavam correlacionados.

Segundo Mantovani \& Martins (1988), o padrão fenológico vegetativo da maioria das espécies herbáceas está mais relacionado às adaptações reprodutivas do que aquele das espécies arbustivoarbóreas. Os ramos aéreos das espécies geófitas e hemicriptófitas morrem após a floração e a frutificação, reduzindo normalmente a planta ao seu sistema subterrâneo. Plantas com xilopódio podem emitir mais de um ramo de brotamento em diferentes épocas do ano.

A dormência das gemas pode ser induzida por baixas temperaturas, variação do fotoperíodo ou estresse hídrico (Válio 1979, Figueiredo \& Dietrich 1981, Salisbury \& Ross 1992, Crabbé \& Barnola 1996). 
Em Santa Rita do Passa Quatro, o período de dormência variou entre cada espécie, porém, para a maioria, o brotamento se deu a partir de outubro, quando há aumentos acentuados da pluviosidade e da temperatura (Figuras 5.1 e 5.2), bem como da umidade relativa do ar e da reposição de água no solo, que se iniciam a partir do final de setembro (Grise 1971, Martins 1982). A produção de algumas auxinas, responsáveis pelo crescimento, é inibida pela diminuição do comprimento do dia. À medida que o fotoperíodo aumenta, estas substâncias passam a ser sintetizadas novamente e a planta retoma seu desenvolvimento (Salisbury \& Ross 1992), procurando maximizar sua produtividade (Schaik et al. 1993). Neste período de brotamento, as reservas de carboidratos e nutrientes conferem àquelas espécies que as possuem um alto valor competitivo (Cannel \& Dewar 1994).

A quebra de dormência nas espécies herbáceas pode estar relacionada com as variações no peso seco dos orgãos subterrâneos, além do aumento da temperatura e da pluviosidade (Figueiredo \& Dietrich 1981).

O brotamento coincidiu com o final da estação seca e início da chuvosa também nas espécies estudadas em Goiânia (Rizzo et al. 1971), em Mogi-Guaçu (Mantovani \& Martins 1988), em Cuiabá (Nascimento et al. 1990) e em Pirassununga (Batalha et al. no prelo). 
Estação Meteorológica DAEE (C4-107)

SANTA RITA DO PASSA QUATRO - SP

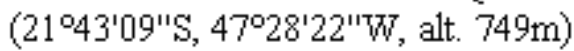

[10]

[21.5] [1499]

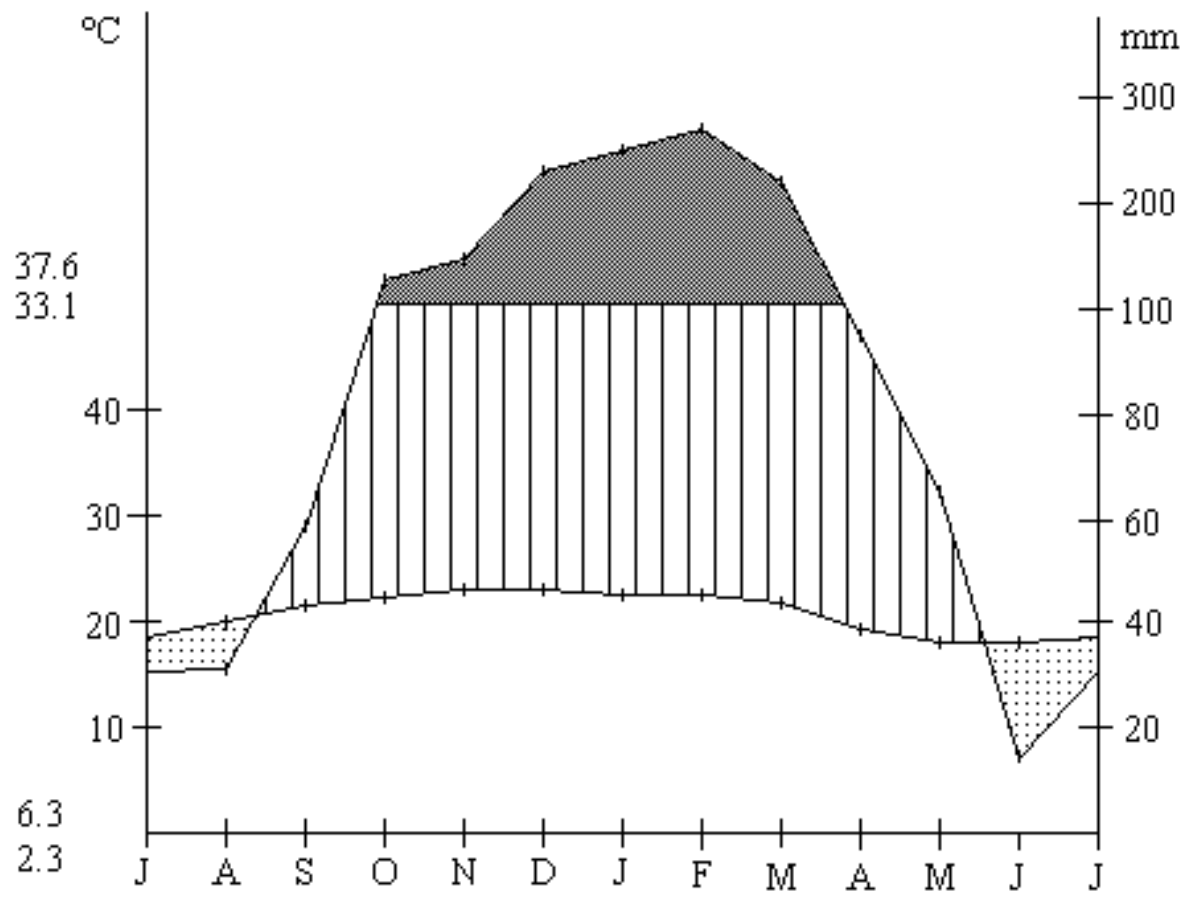

Figura 5.1 - Climadiagrama elaborado a partir dos dados obtidos na estação meteorológica DAEE C4-107, localizada

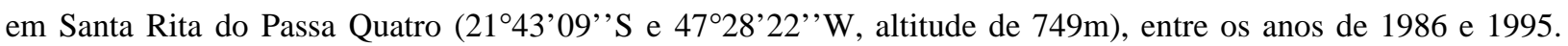
Legenda: $\mathrm{m}=$ temperatura média mensal mínima, $\mathrm{m}=$ temperatura mínima absoluta, $\mathrm{M}=$ temperatura média mensal máxima, $\mathrm{M}$ = temperatura máxima absoluta. 


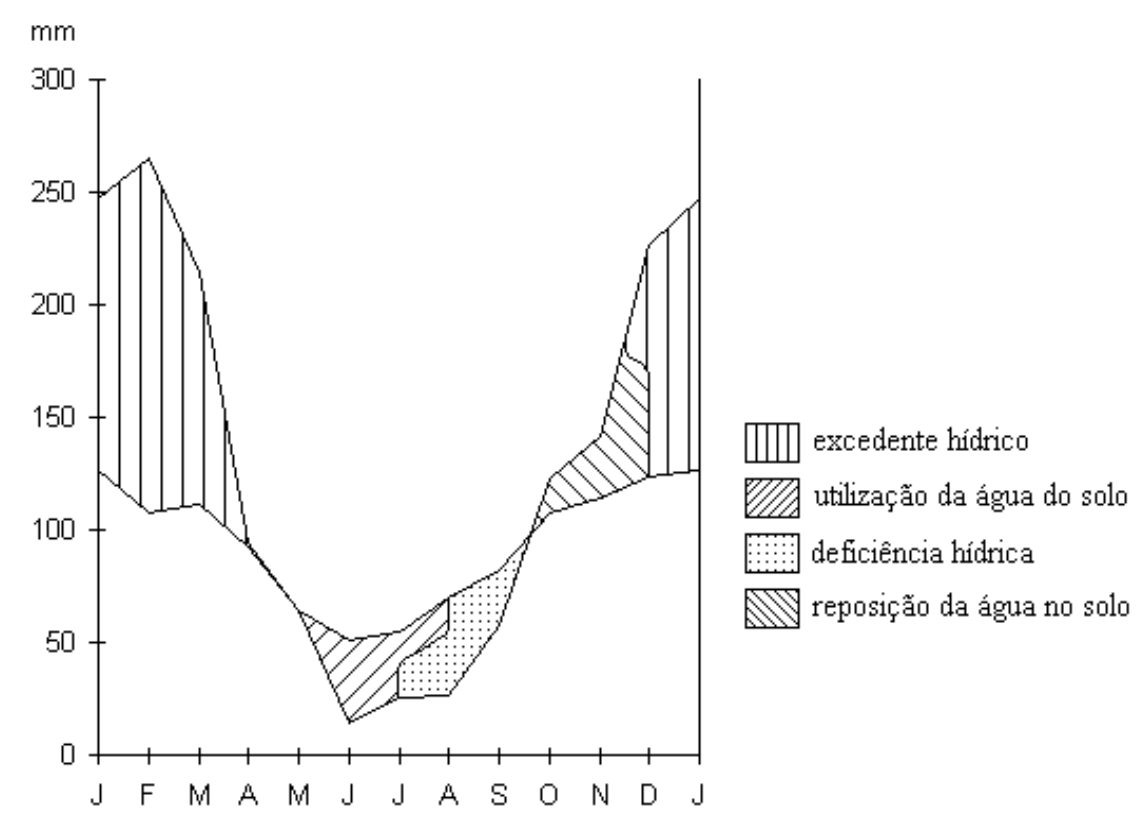

Figura 5.2 - Balanço hídrico elaborado a partir dos dados obtidos na estação meteorológica DAEE C4-107, localizada em Santa Rita do Passa Quatro (2143'09'’S e 47²8'22'’W, altitude de 749m), entre os anos de 1986 e 1995.

\section{Adaptações reprodutivas}

Foram analisadas como adaptações reprodutivas as épocas de floração e de frutificação, relacionando-as com as variações climáticas, as adaptações a polinizadores e a dispersão dos diásporos.

O número de espécies em floração foi mais elevado no período que vai de setembro a abril, atingindo seu valor máximo em fevereiro e mínimo em agosto (Figura 5.3). Este padrão foi semelhante àqueles observados por Mantovani \& Martins (1988) para Mogi-Guaçu e por Batalha et al. (no prelo) para Pirassununga. Neste período, a pluviosidade, o comprimento do dia, a temperatura e a umidade relativa médias mensais são maiores e estão diretamente relacionadas com o aumento na floração (Mantovani \& Martins 1988). 


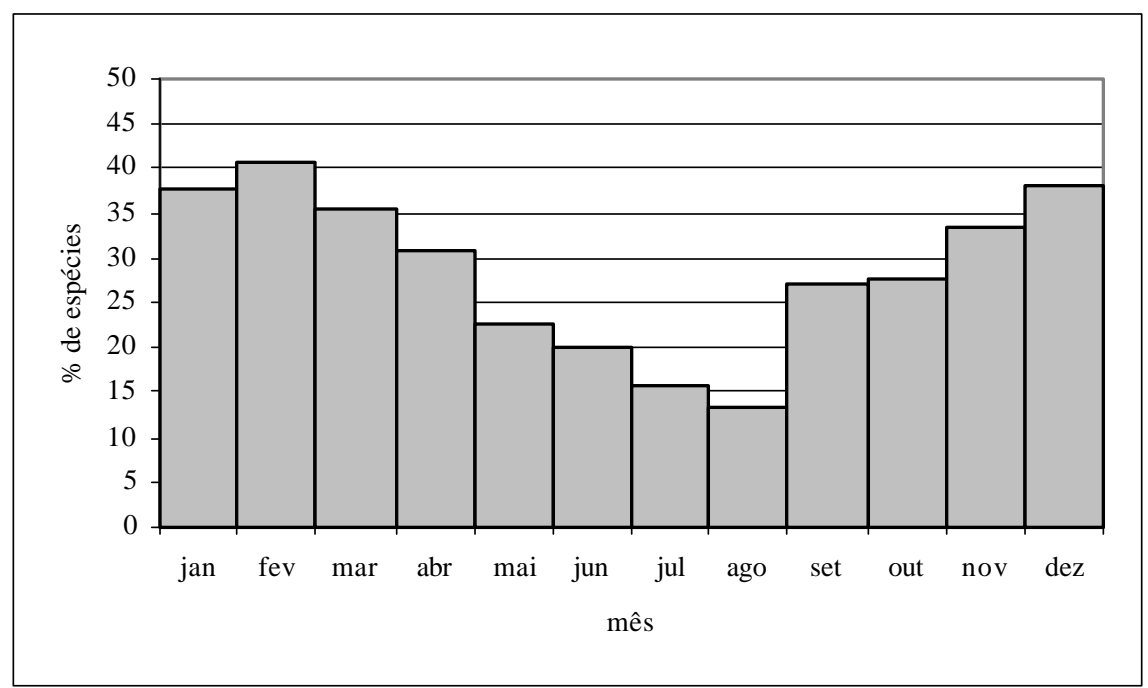

Figura 5.3 - Números totais de espécies de cerrado "sensu lato" em floração ao longo do ano na ARIE Cerrado Péde-Gigante, Santa Rita do Passa Quatro, São Paulo (21³6-44’S e 47³4-41’'W).

A produção de frutos também se deu para um maior número de espécies no período chuvoso, entre setembro e maio, ocorrendo imediatamente após floração (Figura 5.4). A queda no número de espécies frutificando na estação seca foi menos acentuada do que aquela no número de espécies florescendo devido à alta proporção de espécies anemocóricas e autocóricas produzindo frutos neste período.

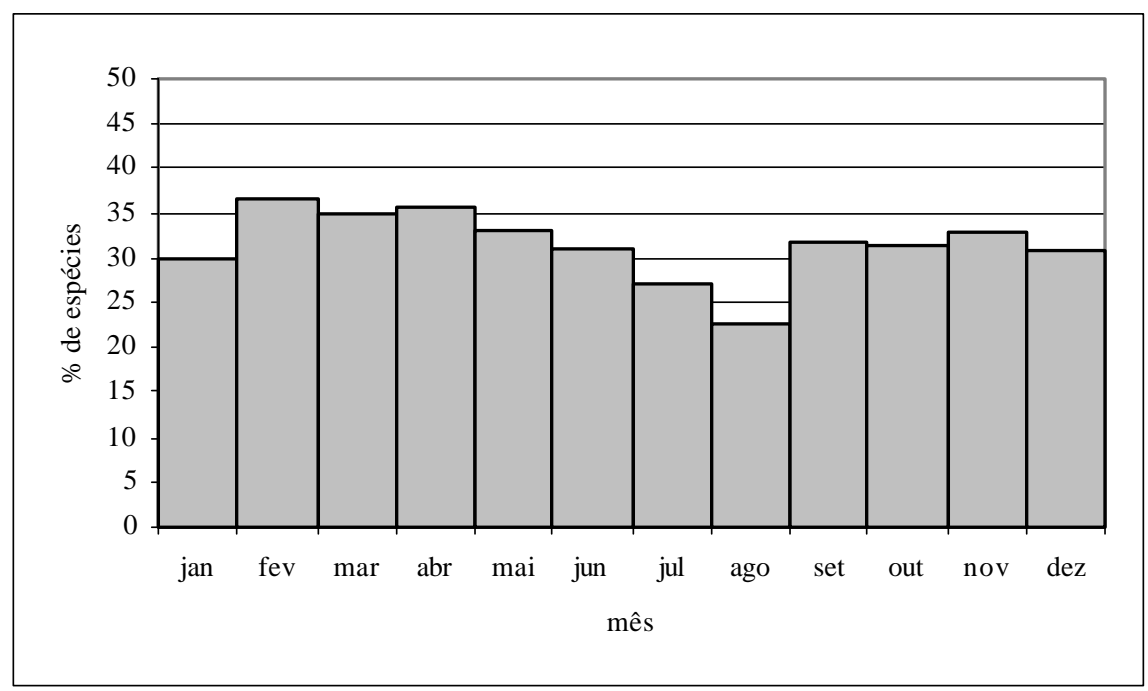

Figura 5.4 - Números totais de espécies de cerrado "sensu lato" em frutificação ao longo do ano na ARIE Cerrado Pé-deGigante, Santa Rita do Passa Quatro, São Paulo (21³6-44’S e 47³4-41’W). 
O espectro biológico (Figura 5.5) mostra que o componente herbáceo-subarbustivo, formado pelas caméfitas, epífitas, geófitas, hemicriptófitas, lianas, parasitas vasculares, semi-parasitas vasculares e terófitas, representou 68,05\% das espécies amostradas, enquanto que o componente arbustivo-arbóreo, composto pelas fanerófitas, representou 33,89\% das espécies. A proporção de espécies arbustivo-arbóreas em relação às herbáceo-subarbustivas foi, aproximadamente, de 1:2 (Capítulo 2). Esta relação se deve ao predomínio da fisionomias de cerrado "sensu stricto" na área (Capítulo 1). Mantovani (1983) comparou o espectro biológico encontrado em Mogi-Guaçu com o de outras áreas de cerrado em Lagoa Santa (Warming 1892) e em Brasília (Ratter 1980). A proporção entre os dois componentes aqui encontrada se aproxima daquela de Brasília, onde predominava o cerradão. Segundo Mantovani (1983), a porcentagem de fanerófitas é maior em fisionomais mais próximas do cerradão.

No componente herbáceo-subarbustivo, a proporção de hemicriptófitas foi menor na ARIE Péde-Gigante do que nas demais áreas, enquanto que a de caméfitas foi maior. Mantovani (1983) afirma que a proporção de caméfitas aumenta em relação às hemicriptófitas, quando as queimadas não são freqüentes, como é o caso da ARIE Pé-de-Gigante. As terófitas não são freqüentes no cerrado (Coutinho 1980) e aquelas encontradas na reserva são, principalmente, espécies ruderais.

O componente herbáceo-subarbustivo teve maior influência nos resultados da flora como um todo, uma vez que foi encontrado nele aproximadamente o dobro de espécies do que no componente arbustivo-arbóreo. 


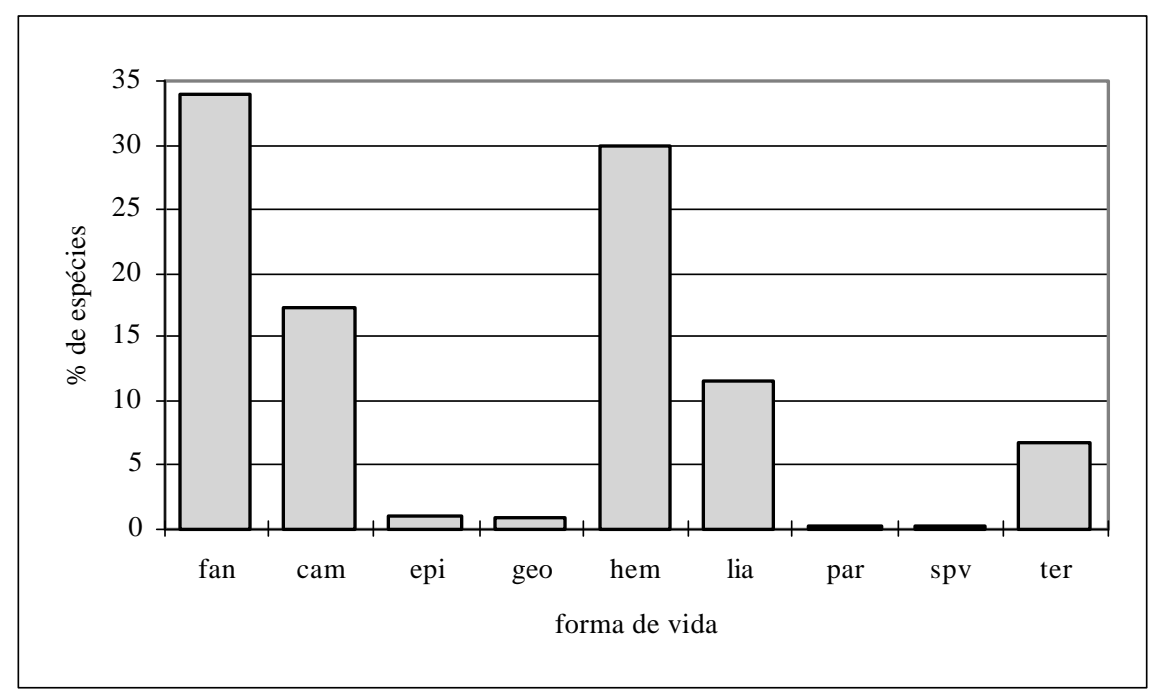

Figura 5.5 - Espectro biológico das espécies de cerrado "sensu lato" na ARIE Cerrado Pé-de-Gigante, Santa Rita do Passa Quatro, São Paulo (2136-44'S e 47³4-41’W). Legenda: fan = fanerófita, cam = caméfita, epi = epífita, geo = geófita, hem = hemicriptófita, lia = liana, par = parasita vascular, spv = semi-parasita vascular, ter = terófita .

Os maiores números de espécies herbáceo-subarbustivas florescendo foram encontrados entre dezembro e março e, frutificando, entre fevereiro e maio, ou seja, no final da estação chuvosa (Figuras 5.6 e 5.7). Este padrão de florescimento e de frutificação tardios na estação chuvosa é encontrado também em savanas de outras regiões tropicais (Sarmiento \& Monasterio 1984). Tenório (1969) observou, em gramíneas, que seu desenvolvimento vegetativo propicia o acúmulo de carboidratos para a floração e frutificação. A necessidade das espécies herbáceas de elaborar e acumular carboidratos antes de florescer e frutificar também foi observada por Figueiredo \& Dietrich (1981). Sarmiento \& Monasterio (1984) levantaram a hipótese de que esta estratégia também asseguraria que a reprodução ocorresse no período com maior garantia de disponibilidade hídrica. Isto ressalta a importância da reprodução vegetativa na manutenção do espaço ocupado pelos indivíduos, pois as reservas contidas nos orgãos subterrâneos são utilizadas para o brotamento (Figueiredo \& Dietrich 1981, Sarmiento \& Monasterio 1984, Mantovani \& Martins 1988). 


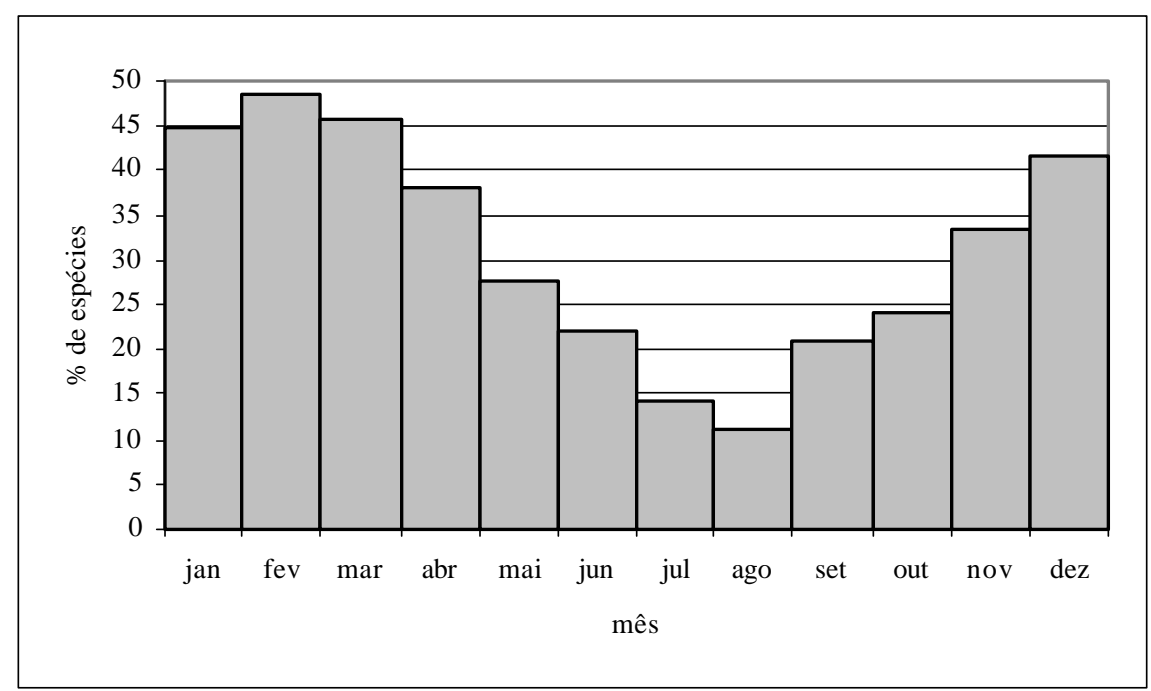

Figura 5.6 - Número de espécies herbáceo-subarbustivas de cerrado "sensu lato" em floração ao longo do ano na ARIE Cerrado Pé-de-Gigante, Santa Rita do Passa Quatro, São Paulo (21³6-44’S e 47³4-41’W).

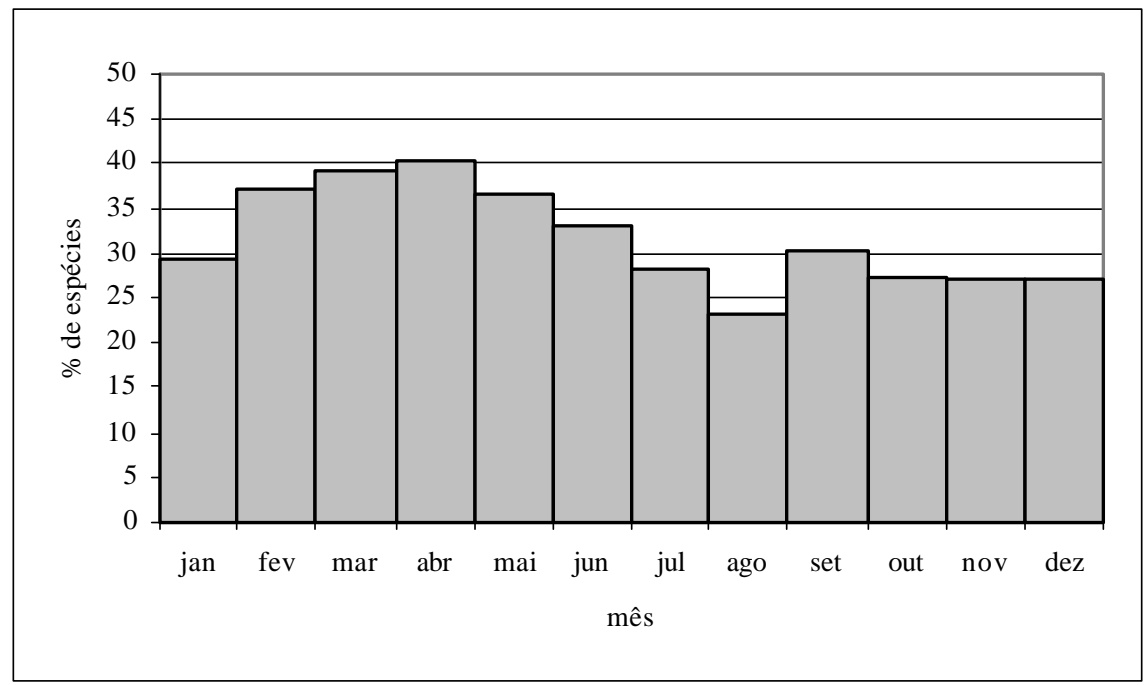

Figura 5.7 - Número de espécies herbáceo-subarbustivas de cerrado "sensu lato" em frutificação ao longo do ano na ARIE Cerrado Pé-de-Gigante, Santa Rita do Passa Quatro, São Paulo (2136-44’S e 47³4-41’W).

O padrão reprodutivo encontrado nas espécies herbáceo-subarbustivas é bem distinto daquele observado para as espécies arbustivo-arbóreas (Figuras 5.8 e 5.9). O período de floração das espécies deste componente está concentrado nos meses de setembro a dezembro, isto é, no início da 
estação chuvosa. Estes resultados estão de acordo com os de Mantovani \& Martins (1988) e de Batalha et al. (no prelo). Em latitudes menores, entretanto, encontrou-se um padrão distinto: no Distrito Federal (Aoki \& Santos 1980) e no Pará (Miranda 1995), a maioria das espécies do componente dominante floresceu no período seco do ano. Isto poderia ser explicado pelas menores variações da temperatura e do comprimento do dia ao longo do ano nestas localidades. Sarmiento \& Monasterio (1984) sugeriram que se as árvores e os arbustos têm sistemas radiculares profundos e acesso à água durante todo o ano, conforme indicaram Rawitscher (1942) e Ferri (1944), existiria uma vantagem adaptativa em se reproduzir na estação seca e reservar à estação chuvosa a função de acúmulo de reservas. Segundo Janzen (1980), a atividade dos insetos polinizadores seria favorecida nesta época do ano, pela ausência de chuvas fortes que provocariam danos às flores e pela deciduidade foliar que tornaria as flores mais visíveis.

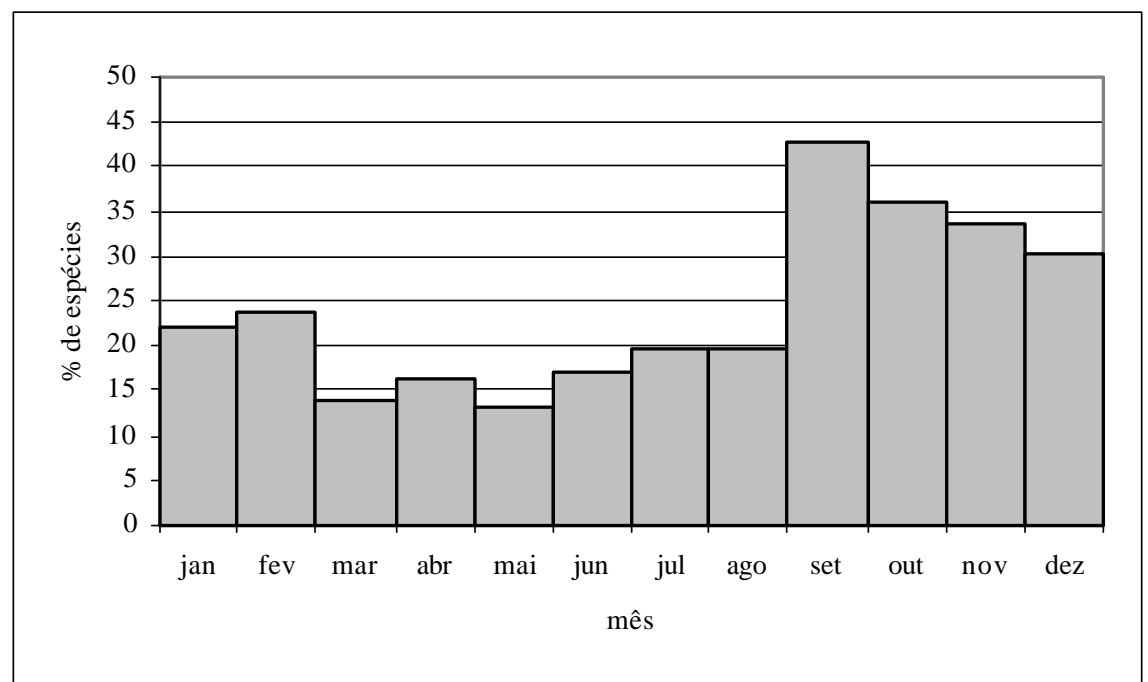

Figura 5.8 - Número de espécies arbustivo-arbóreas de cerrado "sensu lato" em floração ao longo do ano na ARIE Cerrado Pé-de-Gigante, Santa Rita do Passa Quatro, São Paulo (21³6-44’S e 47³4-41’W). 


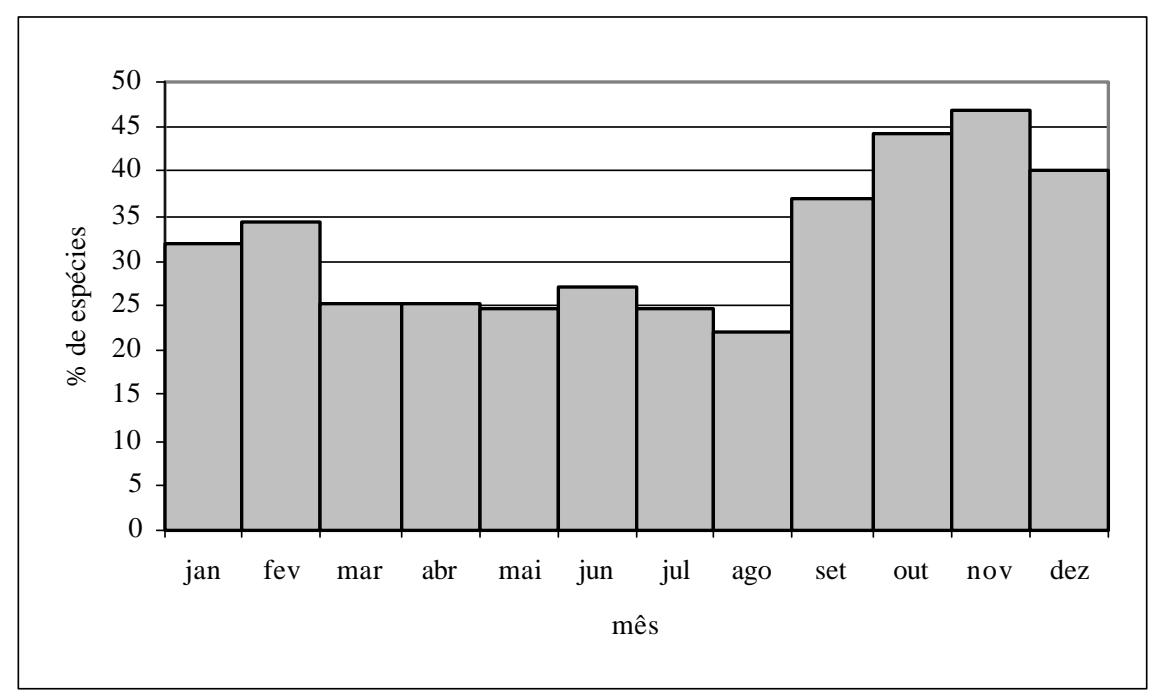

Figura 5.9 - Número de espécies arbustivo-arbóreas de cerrado "sensu lato" em frutificação ao longo do ano na ARIE Cerrado Pé-de-Gigante, Santa Rita do Passa Quatro, São Paulo (21³6-44’S e 47³4-41’W).

A emissão de ramos de brotamento pôde ser observada antes, durante ou depois da floração. Por exemplo, Eriotheca gracilipes (K. Schum.) A. Robyns (Bombacaceae) e Ouratea spectabilis (Mart.) Engl. (Ochnaceae) floresceram antes da abscisão foliar. Jacaranda caroba (Vell) A. DC., Tabebuia aurea (Silva Manso) Benth. \& Hook. f. ex S. Moore e T. ochracea (Cham.) Standl. (Bignoniaceae), e Bowdichia virgilioides H.B.K. (Fabaceae) começaram a florescer quando não havia folhas. Este padrão de floração pode ser visto como uma estratégia para tornar as flores mais aparentes para os polinizadores (Janzen 1980). A floração e o brotamento de espécies lenhosas do cerrado antes do início da estação chuvosa já havia sido mencionado por Rawitscher (1942) e indicam a disponibilidade de água neste período, pelo menos para as espécies com sistema radicular profundo (Ferri 1944).

Muitas espécies também iniciaram sua floração concomitante ao brotamento, tais como Hancornia speciosa Gomez (Apocynaceae), Machaerium acutifolium Vogel (Fabaceae), Byrsonima intermedia A. Juss. (Malpighiaceae), Anadenanthera falcata (Benth.) Speg. (Mimosaceae), Campomanesia pubescens (A. DC.) O. Berg, Myrcia bella Cambess. e M. lasiantha A. DC. (Myrtaceae), e Qualea grandiflora Mart. (Vochysiaceae). 
Como a floração, a época de frutificação, em Santa Rita do Passa Quatro, esteve concentrada no ínicio da estação úmida, com maior número de espécies frutificando em novembro (Figura 5.9). Em Pirassununga (Batalha et al. no prelo), o período de frutificação da maioria das espécies esteve disperso por toda a estação úmida.

Diversas espécies arbustivo-arbóreas não foram encontradas férteis durante o período de coleta, como, por exemplo: Aspidosperma tomentosum Mart. (Apocynaceae), Cybistax antisyphillitica Mart. (Bignoniaceae), Pseudobombax longiflorum (Mart. \& Zucc.) A. Robyns (Bombacaceae), Sclerolobium paniculatum Benth. (Ceasalpiniaceae), Kielmeyera coriacea Mart. (Clusiaceae), Connarus suberosus Planch. (Connaraceae), Acosmium dasycarpum (Vogel) Yakovlev e Vatairea macrocarpa (Benth.) Ducke (Fabaceae), Stryphnodendron adstringens (Mart.) Coville (Mimosaceae), Myrcia pubipetala Miq. (Myrtaceae) e Matayba elaeagnoides Radlk. (Sapindaceae). Labouriau (1963) afirmou que, no cerrado, várias espécies não florescem todos os anos, enquanto outras o fazem mais de uma vez por ano. Mantovani \& Martins (1988) levantaram a hipótese de que se a propagação vegetativa é freqüente, a não floração por um ou mais anos poderia representar uma estratégia adaptativa, pois reservas seriam economizadas e herbívoros e parasitas que dependessem de sincronia da floração seriam evitados.

Do total de espécies encontradas, 34,44\% são anemocóricas, 26,67\% são autocóricas e 38,89\% são zoocóricas (Figura 5.10). Essas proporções se aproximam daquelas obtidas por Batalha et al. (no prelo) em Pirassununga. Mantovani \& Martins (1988) encontraram em Mogi-Guaçu uma proporção maior de espécies autocóricas e menor de zoocóricas. Estes autores, porém, consideraram muitas espécies de gramíneas, aqui consideradas zoocóricas, como autocóricas. Para o componente herbáceo-subarbustivo, a proporção é de 35,92\%, 35,92\% e 28,16\% de espécies anemocóricas, autocóricas e zoocóricas, respectivamente. Para o componente arbustivo-arbóreo, 30,33\% das espécies são anemocóricas, 6,56\%, autocóricas e a maioria, 63,66\%, é zoocórica. Do 
total de espécies anemocóricas, 70,96\% pertecem ao primeiro componente, bem como 91,67\% das autocóricas. Por outro lado, 55\% das espécies zoocóricas estão no componente arbustivo-arbóreo. Gottsberger \& Silberbauer-Gottsberger (1983) também encontraram uma maior proporção de espécies anemo e autocóricas no componente herbáceo em relação ao componente arbóreo, e de espécies zoocóricas no componente arbóreo em relação ao componente herbáceo.

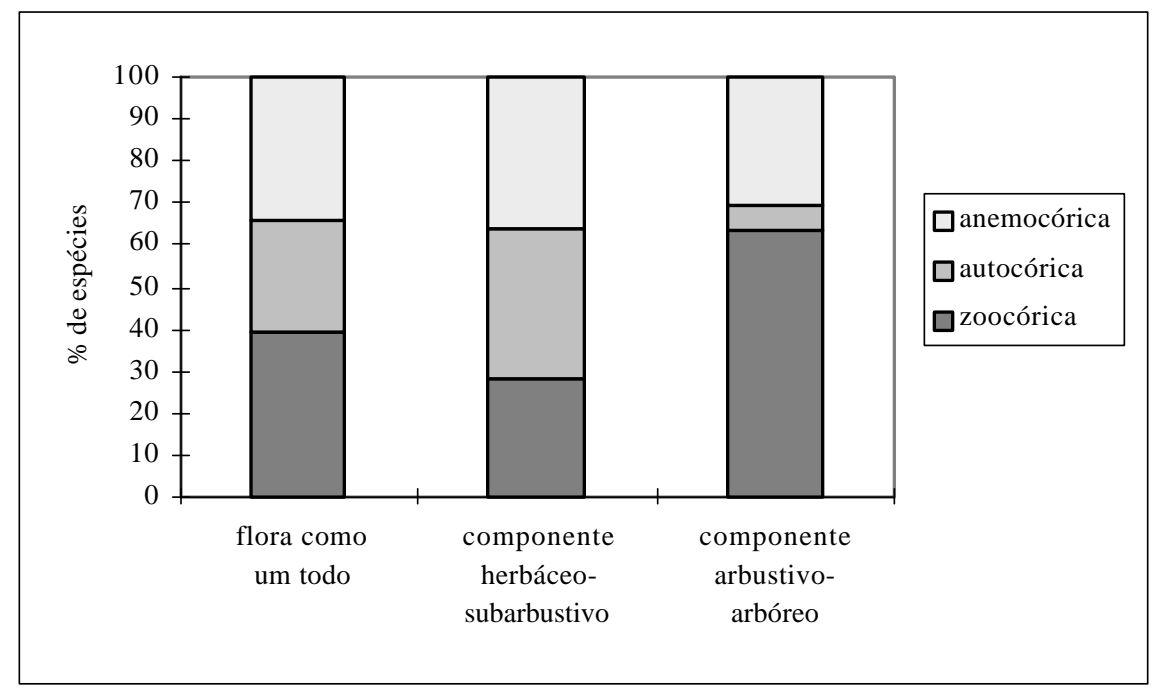

Figura 5.10 - Distribuição, em porcentagem, das síndromes de dispersão das espécies de cerrado "sensu lato" na ARIE Cerrado Pé-de-Gigante, Santa Rita do Passa Quatro, São Paulo (21³6-44’S e 47³4-41’W).

As espécies anemocóricas na ARIE Cerrado Pé-de-Gigante floresceram principalmente entre dezembro e abril para a flora como um todo e para seus dois componentes (Figuras 5.11, 5.13 e 5.15). Para a flora como um todo e para o componente herbáceo-subarbustivo, a frutificação ocorreu principalmente entre junho e outubro (Figuras 5.12 e 5.14). Já no componente arbustivo-arbóreo, a frutificação foi mais intensa entre julho e dezembro (Figura 5.16).

Quanto às espécies autocóricas, a floração se concentrou nos meses de dezembro a abril na flora como um todo e no componente herbáceo-subarbustivo (Figuras 5.11 e 5.13) No componente arbustivo-arbóreo, a floração das espécies autocóricas esteve concentrada nos meses de fevereiro a abril (Figura 5.15). A frutificação na flora como um todo ocorreu principalmente de janeiro a junho, 
com o maior número de espécies em fruto em março (Figura 5.12). Este mesmo padrão foi observado para o componente herbáceo-subarbustivo (Figura 5.14). Já para as espécies arbustivoarbóreas, os maiores valores foram encontrados nos meses de junho a dezembro (Figura 5.16).

A floração das espécies anemocóricas e autocóricas ocorreu preferencialmente na segunda metade da estação chuvosa. Como os frutos devem amadurecer no período imediatamente posterior à floração (Mantovani \& Martins 1988), o período de frutificação mais intensa para as espécies com estas síndromes de dispersão deveria estar concentrado na estação seca. De fato, nos meses mais secos, junho a agosto, a proporção de plantas anemocóricas e autocóricas frutificando foi maior do que a de zoocóricas, padrão este também encontrado por Gottsberger \& Silberbauer-Gottsberger (1983), Mantovani \& Martins (1988), Miranda (1995) e Batalha et al. (no prelo). Os frutos anemocóricos e autocóricos são em geral secos e, desse modo, para a liberação das sementes, seu pericarpo sofre um processo de desidratação, que acaba por provocar sua deiscência. Augspurger \& Franson (1987) observaram que, em áreas de clima sazonal, a dispersão dos diásporos anemocóricos é mais eficiente na estação seca. A deciduidade foliar observada principalmente nas plantas anemocóricas também facilita a dispersão dos dissemínulos (Matthes et al. 1988). 


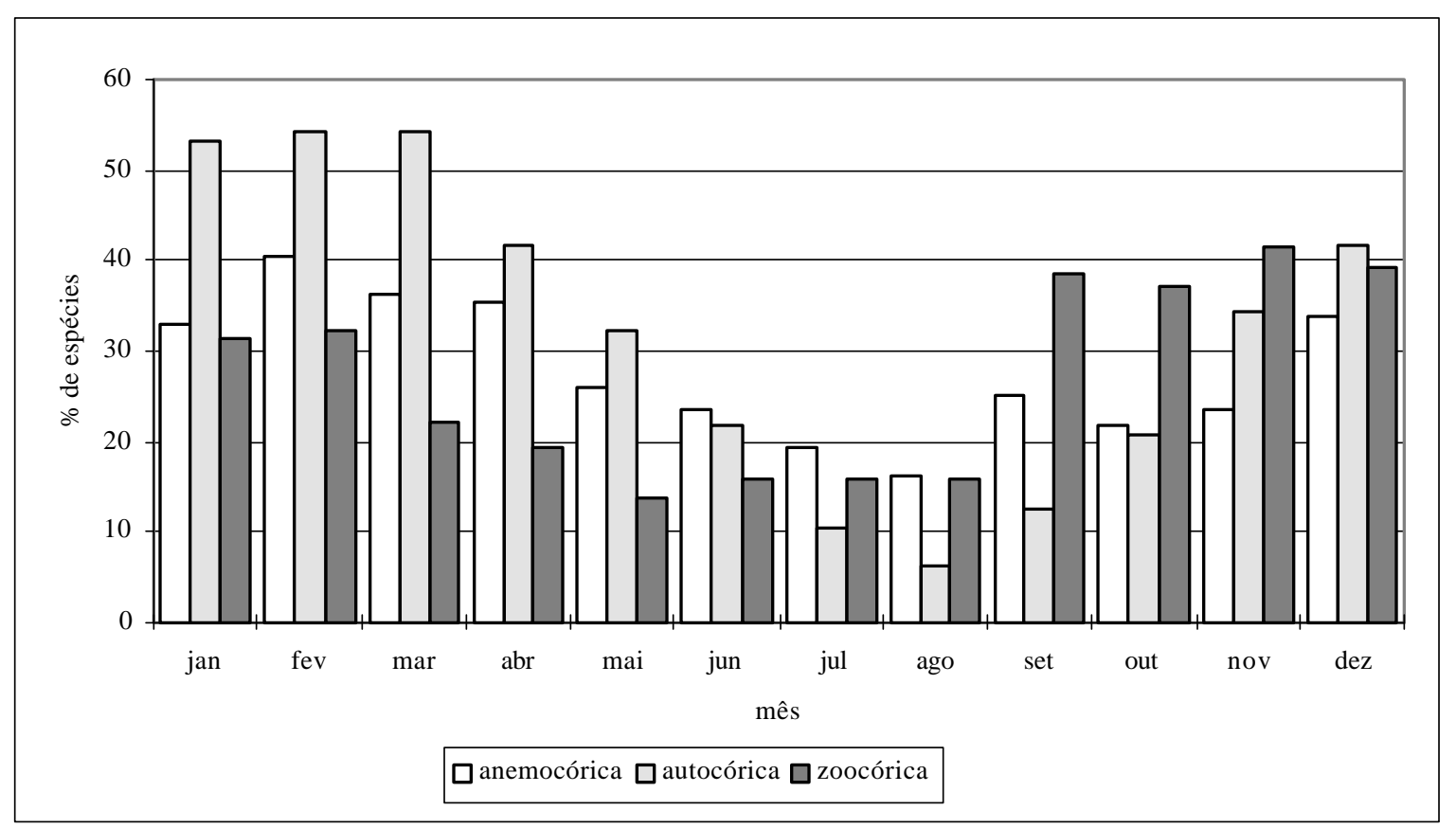

Figura 5.11 - Distribuição, em porcentagem, das espécies de cerrado "sensu lato" em floração ao longo do ano na ARIE Cerrado Pé-de-Gigante, Santa Rita do Passa Quatro, São Paulo (21 $36-44^{\prime}$ S e $\left.47^{\circ} 34-41^{\prime} \mathrm{W}\right)$, de acordo com a síndrome de dispersão de seus diásporos.

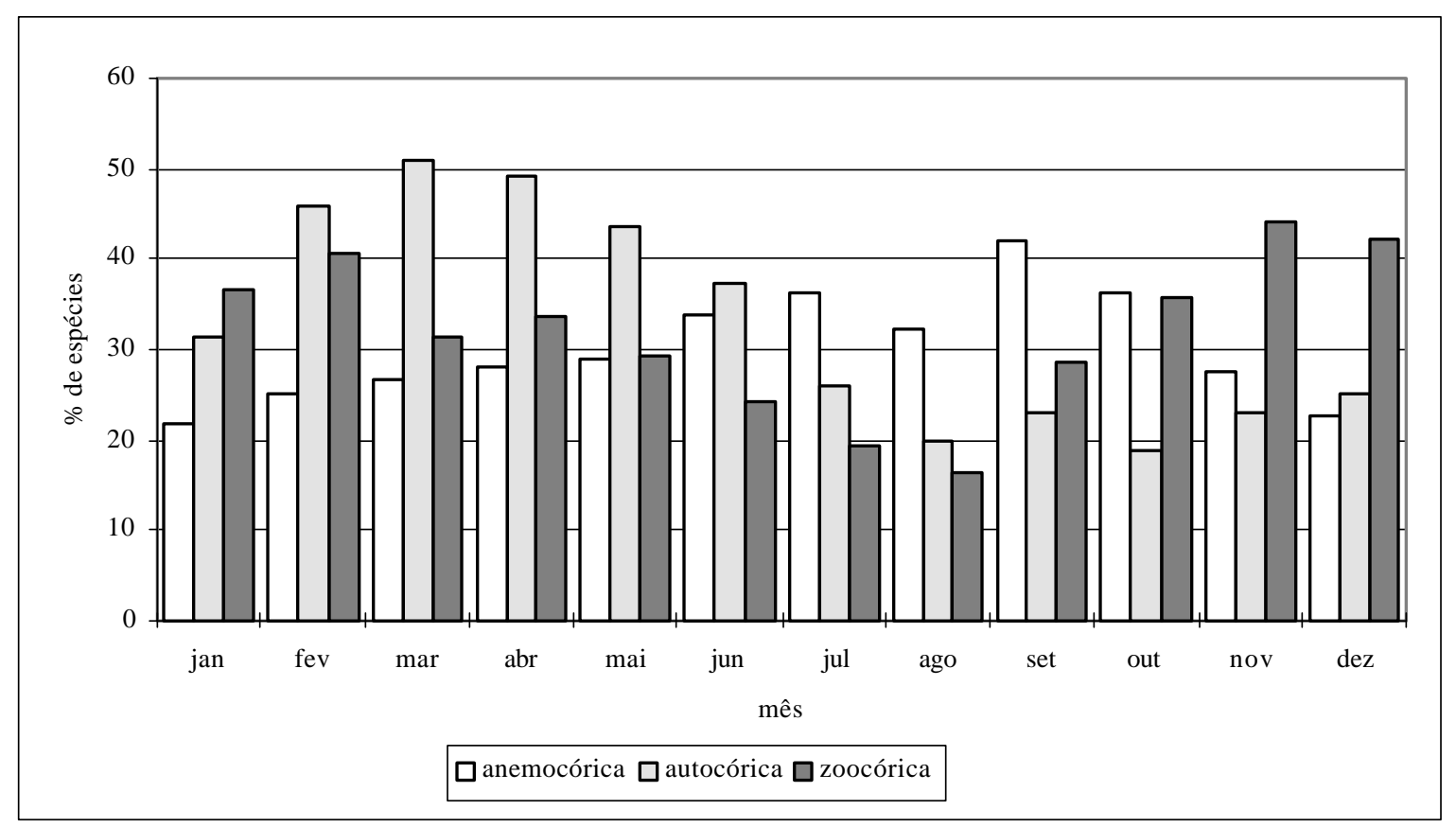

Figura 5.12 - Distribuição, em porcentagem, das espécies de cerrado "sensu lato" em frutificação ao longo do ano na ARIE Cerrado Pé-de-Gigante, Santa Rita do Passa Quatro, São Paulo (21³6-44'S e 47³4-41'W), de acordo com a síndrome de dispersão de seus diásporos. 


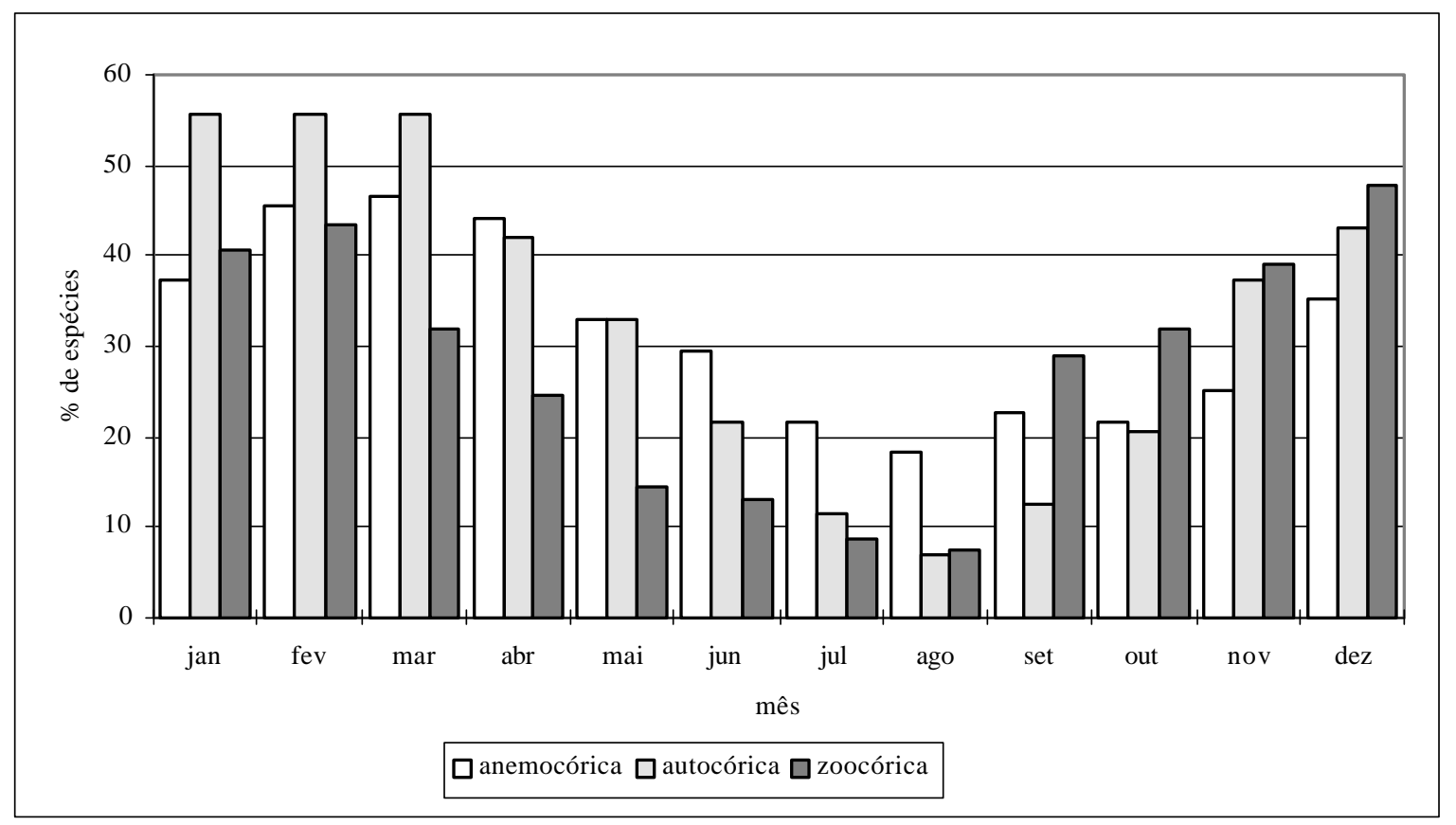

Figura 5.13 - Distribuição, em porcentagem, das espécies herbáceo-subarbustivas de cerrado "sensu lato" em floração ao longo do ano na ARIE Cerrado Pé-de-Gigante, Santa Rita do Passa Quatro, São Paulo (216-44'S e 47³4-41'W), de acordo com a síndrome de dispersão de seus diásporos.

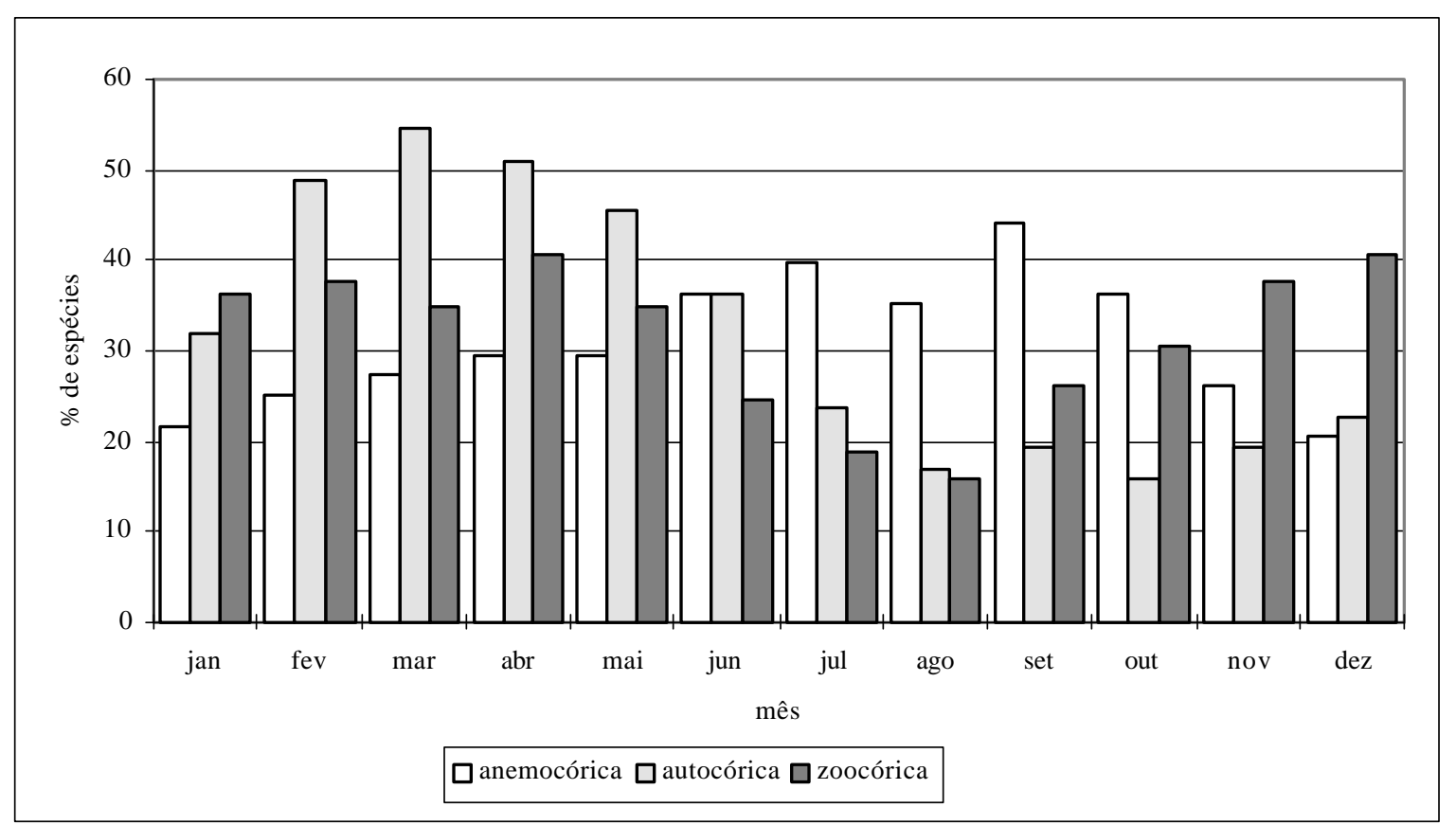

Figura 5.14 - Distribuição, em porcentagem, das espécies herbáceo-subarbustivas de cerrado "sensu lato" em frutificação ao longo do ano na ARIE Cerrado Pé-de-Gigante, Santa Rita do Passa Quatro, São Paulo (21³6-44'S e 47³4$\left.41^{\prime} \mathrm{W}\right)$, de acordo com a síndrome de dispersão de seus diásporos. 


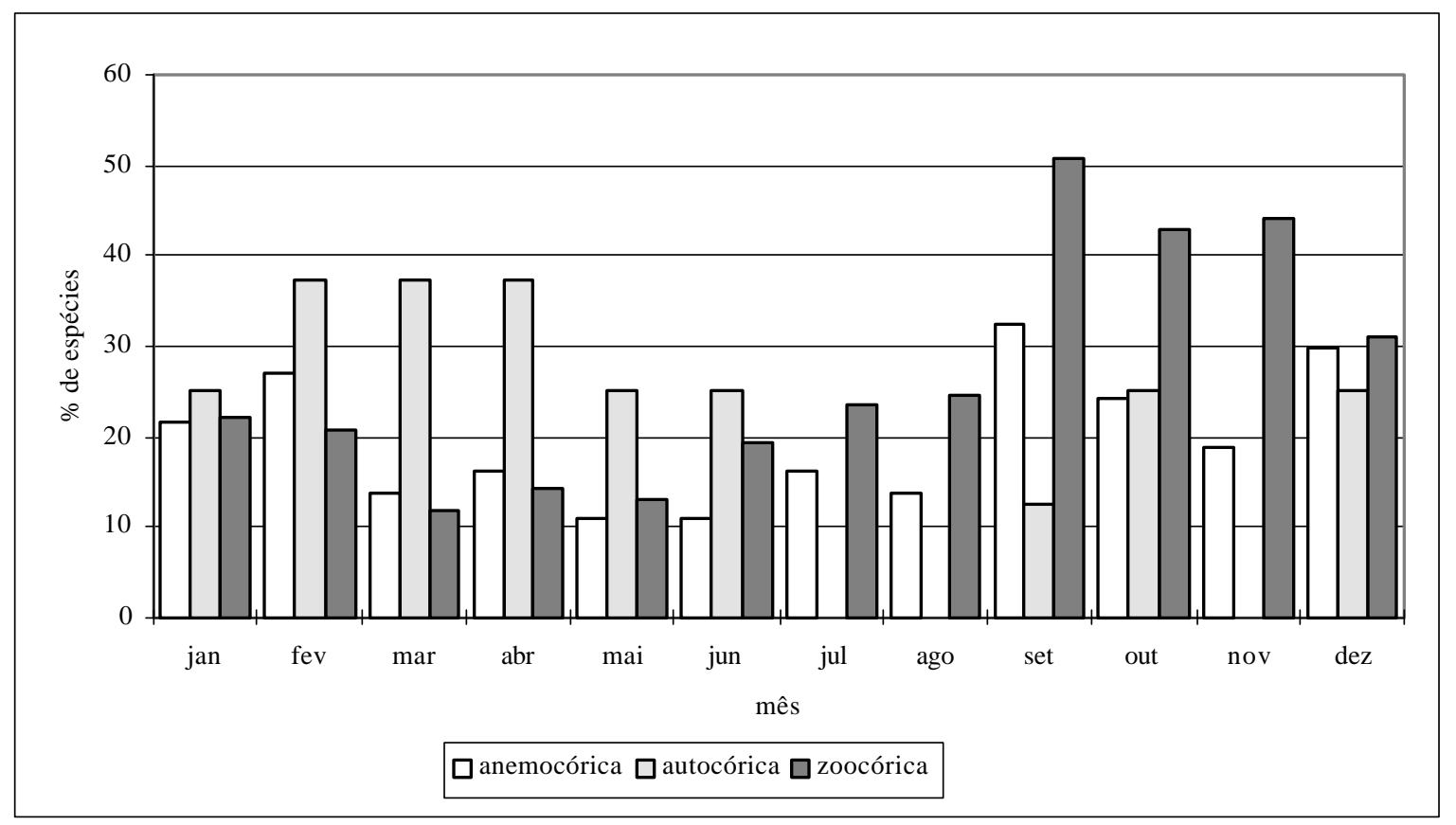

Figura 5.15 - Distribuição, em porcentagem, das espécies arbustivo-arbóreas de cerrado "sensu lato" em floração ao longo do ano na ARIE Cerrado Pé-de-Gigante, Santa Rita do Passa Quatro, São Paulo (216-44'S e 47³4-41'W), de acordo com a síndrome de dispersão de seus diásporos.

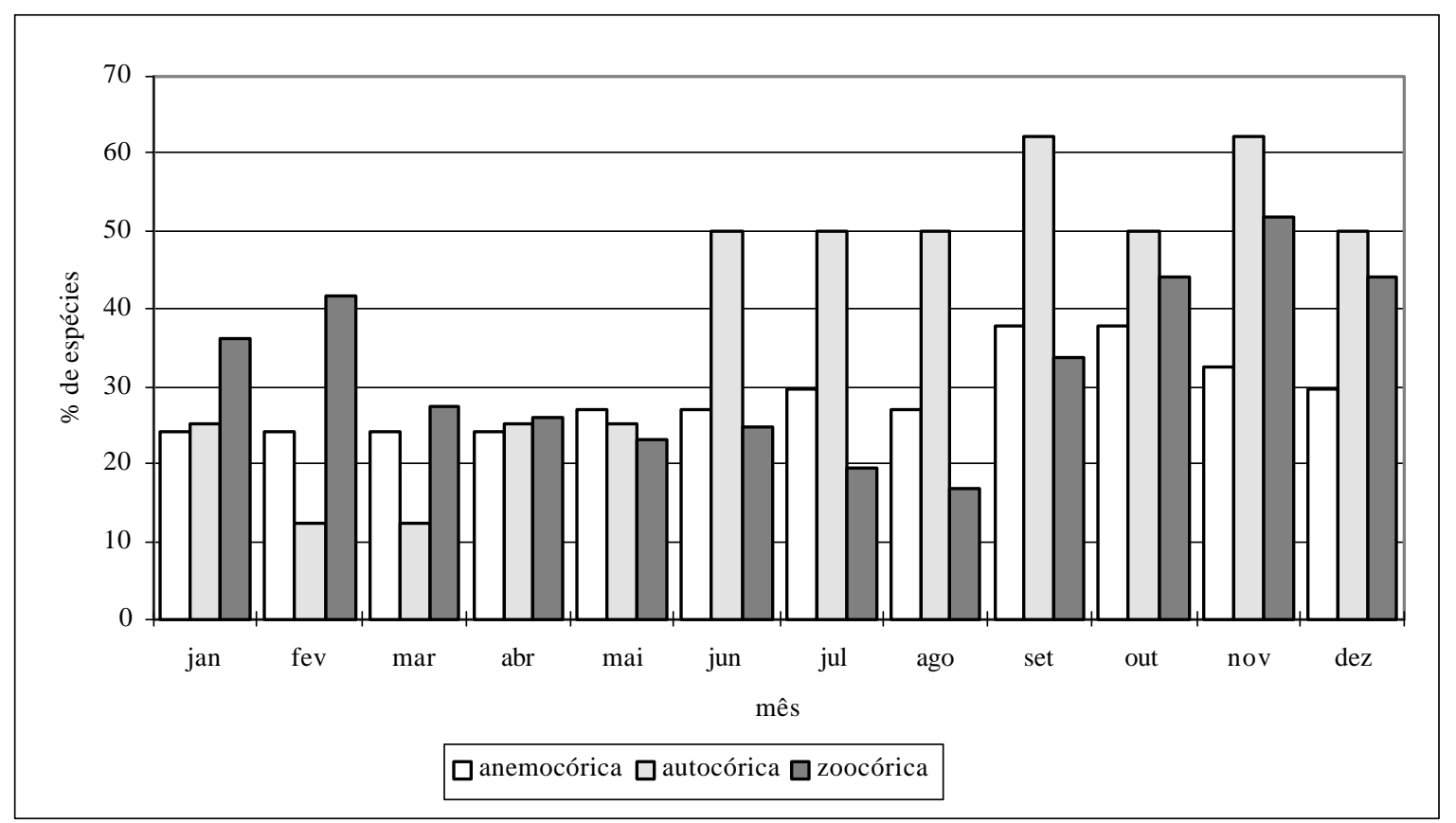

Figura 5.16 - Distribuição, em porcentagem, das espécies arbustivo-arbóreas de cerrado "sensu lato" em frutificação ao longo do ano na ARIE Cerrado Pé-de-Gigante, Santa Rita do Passa Quatro, São Paulo (21³6-44'S e 47³4-41'W), de acordo com a síndrome de dispersão de seus diásporos. 
As espécies zoocóricas apresentaram floração mais intensa entre setembro e fevereiro (Figura 5.11). No componente herbáceo-subarbustivo, o período com maior número de espécies florescendo esteve compreendido entre novembro e fevereiro (Figura 5.13), enquanto que no arbustivo-arbóreo este período foi de setembro a novembro (Figura 5.15). O período com os maiores números de espécies em frutificação está compreendido entre outubro e abril (Figura 5.12). As espécies do componente herbáceo-subarbustivo frutificaram principalmente entre os meses de novembro e maio (Figura 5.14). No componente arbustivo-arbóreo, a época com intensidade maior na frutificação intensa foi de outubro a fevereiro (Figura 5.16).

Para as espécies com diásporos com síndrome de dispersão zoocórica, pôde-se notar que, no componente herbáceo-subarbustivo, floresceram e frutificaram poucos meses após o início das chuvas, após o período de acúmulo de carboidratos. As espécies do componente arbustivo-arbóreo, entretanto, floresceram no final da estação seca e no início da estação chuvosa e apresentaram um longo período de frutificação na época de maior calor e umidade, quando seus frutos carnosos se mantêm atraentes por mais tempo, apresentando o mesmo padrão observado por Gottsberger \& Silberbauer-Gottsberger (1983), Mantovani \& Martins (1988), Miranda (1995) e Batalha et al. (no prelo).

Trabalhos realizados com o componente arbóreo em outras formações vegetais de clima sazonal (Frankie et al. 1974, Morellato et al. 1989) mostraram padrões semelhantes àquele do cerrado, ou seja, queda de folhas na estação seca, brotamento após as primeiras chuvas, frutificação de espécies anemocóricas e autocóricas na estação seca, e frutificação de espécies zoocóricas mais dispersa ao longo de toda estação chuvosa. Frankie et al. (1974), todavia, encontraram mais espécies florescendo na estação seca do que na chuvosa, como em áreas de cerrado situadas em latitudes mais baixas (Aoki \& Santos 1980, Miranda 1995). 


\section{Conclusões}

A deciduidade foliar e a morte dos ramos de brotamento e de indivíduos das espécies anuais atingiram seu máximo em agosto, quando a pluviosidade, temperatura média mensal, a umidade relativa média mensal e o comprimento do dia diminuem. O brotamento se deu a partir de outubro, quando estas variáveis climáticas voltam a aumentar.

A proporção de espécies anemo e autocóricas foi maior no componente herbáceo-subarbustivo, ao contrário daquelas zoocóricas, mais freqüentes no componente arbustivo-arbóreo.

Para as espécies com síndrome de dispersão anemocórica, tanto as herbáceo-subarbustivas quanto as arbustivo-arbóreas, encontrou-se um padrão semelhante na floração e na frutificação, com maior número de espécies florescendo no final da estação chuvosa e frutificando por toda a estação seca. As espécies autocóricas dos dois componentes floresceram em maior número no final da estação chuvosa, porém as herbáceo-subarbustivas frutificaram principalmente no final das chuvas e início da seca, enquanto que mais espécies arbustivo-arbóreas produziram frutos ao longo de toda estação seca. Os frutos anemocóricos e autocóricos amadurecem, de modo geral, na estação seca, quando sua dispersão é mais eficiente.

As espécies zoocóricas do componentes herbáceo-subarbustivo apresentaram comportamento distinto daquelas do componente arbustivo-arbóreo quanto à floração. No primeiro componente, um número maior de espécies floresceu na metade da estação chuvosa e no segundo, logo no início desta estação, evidenciando novamente a necessidade das espécies herbáceo-subarbustivas de elaborarem carboidratos. A frutificação ocorreu, em ambos os componentes, para um maior número de espécies, durante toda a estação chuvosa, quando seus frutos carnosos podem se manter atraentes por mais tempo.

A maior proporção de espécies herbáceo-subarbustivas influiu nos resultados obtidos na 
comunidade como um todo, cujos padrões fenológicos se aproximaram do daquele componente.

Os dados aqui encontrados sobre as variações fenológicas vêm, de modo geral, corroborar os resultados obtidos em outros trabalhos realizados em cerrados.

\section{Referências bibliográficas}

AOKI, H. \& SANTOS, J. R. 1980. Estudo da vegetação de cerrado na área do Distrito Federal, a partir de dados orbitais. Dissertação de Mestrado. Instituto Nacional de Pesquisas Espaciais.

AUGSPURGER, C. K. \& FRANSON, S. E. 1987. Wind dispersal of artificial fruits varying in mass, area and morphology. Ecology 68: 27-42.

BARRADAS, M. M. 1972. Informações sobre a floração, frutificação e dispersão do piqui Caryocar brasiliense Camb. (Caryocaraceae). Ciênc.Cult. 24: 1063-8.

BARROS, M. A. G. E. \& CALDAS, L. S. 1980. Acompanhamento de eventos fenológicos apresentados por cinco gêneros nativos do cerrado (Brasília, DF). Brasil Flor. 10: 7-14.

BATAlHA, M. A., ARAGAKI, S. \& MANTOVANI, W. No prelo. Variações fenológicas das espécies do cerrado em Emas (Pirassununga, SP). Acta Bot. Bras.

BLOOM, A. J., CHAPIN III, F. S. \& MOONEY, H. A. 1985. Resource limitation in plants - an economic analogy. Ann. Rev. Ecol. Syst. 16: 363-92.

CANNEL, M. G. R. \& DEWAR, R. C. 1994. Carbon allocation in trees: a review of concepts for modelling. Adv. Ecol .Res. 25: 59-104.

CASTRO, A. A. J. F. 1987. Florística e fitossociologia de um cerrado marginal brasileiro, Parque Estadual de Vassununga, Santa Rita do Passa-Quatro, SP. Tese de Mestrado. Univ. Est. Campinas.

COUTINHO, L. M. 1980. As queimadas e seu papel ecológico. Brasil Flor.10: 15-23. 
CRABBÉ, J. \& BARNOLA, P. 1996. A new conceptual approach to bud dormancy in woody plants. In: LANG, G. A. (ed). Plant dormancy. Willingford, CAB.

FERRI, M.G. 1944. Transpiração de plantas permanentes dos "cerrados". Bol. Fac. Filos. Ciênc. Letr. Univ. S. Paulo, Botânica 4: 155-224.

FIGUEIREDO, R. C. L. \& DIETRICH, S. M. C. 1981. Variações estacionais nos compostos de reserva e no metabolismo do xilopódio de Ocimum nudicaule Benth. var. anisifolia Giul. (Labiatae). Revta. Bras. Bot. 4: 73-82.

FOURNIER, L. A. 1969. Estudo preliminar sobre la floración en el Roble de sabana Tabebuia pentaphylla (L.) Hemsl. Revta. Biol. Tropical 15(2): 259-67.

FRANKIE, G. W., BAKER, H. G. \& OPLER, P. A. 1974. Comparative phenological studies of trees in tropical wet and dry forest in the lowlands Costa Rica. J. Ecol. 62: 881-919.

GERLOFF, G. 1976. Plant efficiencies in the use of nitrogen, phosphorus and potassium. In WRIGHT, M. J. (ed). Plant adaptation to mineral stress in problem soils. New York, Ithaca.

GOTTSBERGER, G. \& SILBERBAUER-GOTTSBERGER, I. 1983. Dispersal and distribution in the cerrado vegetation of Brazil. Sonderbd. Naturwiss. Ver. Hemburg 7: 315-52.

GRISE, B. M. 1971. Estudo comparativo do balanço hídrico de Ouratea spectabilis (Mart.) Engl. em diferentes condições ecológicas. Dissertação de Mestrado. Univ. S. Paulo.

JANZEN, D. H. 1980. Ecologia vegetal nos trópicos. São Paulo, EPU e EDUSP.

KIKUZAWA, K. 1995. The basis for variation in leaf longevity of plants. Vegetatio 121: 89-100.

LABOURIAU, L. G. 1963. Problemas de fisiologia ecológica dos cerrados. In: FERRI, M. G. (coord). I Simpósio sobre o cerrado. São Paulo, Edgard Blücher e EDUSP.

LIETH, H. 1974. Introduction to phenology and the modeling of seasonality. In: LIETH, H. (ed) Phenology and seasonality modeling. Berlin, Springer-Verlag.

MANTOVANI, W. 1983. Composição e similaridade florística, fenologia e espectro biológico do 
cerrado da reserva biológica de Moji Guaçu, Estado de São Paulo. Dissertação de Mestrado. Univ. Est. Campinas.

MANTOVANI, W. \& MARTINS, F. R. 1988. Variações fenológicas das espécies do cerrado da Reserva Biológica de Moji Guaçu, Estado de São Paulo. Revta. Bras. Bot. 11: 101-12.

MARTINS, F. R. 1982. O balanço hídrico sequiêncial e o caráter semidecíduo da floresta do Parque Estadual do Vassununga, Santa Rita do Passa Quatro (SP). Revta. Bras. Estat. 43: 353-91.

MATTHES, L. A. F., LEITÃO-FILHO, H. F. de, MARTINS, F.R. 1988. Bosque dos Jequitibás (Campinas, SP): Composição florística e estrutura do estrato arbóreo. In: CONGR. SOC. BOT. S. PAULO 5, Botucatu, Anais. Soc. Bot. S. Paulo, Campinas. p.55-76.

MIRANDA, I. S. 1995. Fenologia do estrato arbóreo de uma comunidade de Alter-do-Chão, PA. Revta. Brasil. Bot. 18(2): 235-40.

MOHR, H. \& SCHOPFER, P. 1995. Plant physiology. Berlin, Springer-Verlag.

MORAIS, H. C., DINIZ, I. R. \& BAUMGARTEN, L. 1995. Padrões de produções de folhas e sua utilização por larvas de Lepidoptera em um cerrado de Brasília. Revta. Brasil. Bot. 18(2): 163-70.

MORELlATO, L. P., RODRIGUES, R. R., LEITÃO-FILHO, H. F. de \& JOLY, C. A. 1989. Estudo comparativo da fenologia de espécies arbóreas de floresta de altitude e floresta mesófila semidecídua na Serra do Japi, Jundiaí, São Paulo. Revta. Brasil. Bot. 12: 85-98.

NASCIMENTO, M. T., VILLELA, D. M. \& LACERDA, L. D. de. 1990. Foliar growth, longevity and herbivory in two "cerrado" species near Cuiabá, MT, Brazil. Revta. Brasil. Bot. 13: 27-32.

PIJL, L. van der. 1972. Principles of dispersion in higher plants. Berlin, Springer-Verlag.

RACHID, M. 1947. Transpiração e sistemas subterrâneos de vegetação de verão dos campos cerrados de Emas. Bol. Fac. Filos. Ciênc. Letr. Univ. S. Paulo, Botânica 5: 1-140.

RACHID-EDWARDS, M. 1956. Alguns dispositivos para proteção de plantas contra a seca e o fogo. Bol. Fac. Filos. Ciênc. Letr. Univ. S. Paulo, Botânica 13: 36-72. 
RATHCKE, B. \& LACEY, E. P. 1985. Phenological patterns of terrestrial plants. Ann. Rev. Ecol. Syst. 16: 179-214.

RATTER, J. A. 1980. Notes on the vegetation of Fazenda Água Limpa (Brasília - DF, Brasil). Edinburgh, Royal Botanical Garden.

RAUNKIAER, C. 1934. The life forms of flowering plants and statistical geography. Oxford, Claredon.

RAWITSCHER, F. 1942. Algumas noções sobre a transpiração e o balanço de água de plantas brasileiras. Anais Acad. Bras. Ciênc. 14: 7-36.

RIBEIRO, J. R. \& CASTRO, L. H. R. 1986. Método quantitativo para avaliar características fenológicas em árvores. Rev. Brasil. Bot. 9: 7-11.

RIDLEY, H. N. 1930. The dispersal of plants throughout the world. London, Kent L. Reeve.

RIZZINI, C. T. 1976. Influência da temperatura sobre a germinação de diásporas do cerrado. Rodriguésia 28: 341-83.

RIZZINI, C. T. 1979. Tratado de fitogeografia do Brasil: aspectos ecológicos. São Paulo, HUCITEC e EDUSP.

RIZZO, J. A., CENTENO, A. J., SANTOS-LOUSA, J. \& FILGUEIRAS, T. S. 1971. Levantamento de dados em áreas do cerrado e da floresta caducifolia tropical do planalto centro-oeste. In FERRI, M. G. (coord). III Simpósio sobre o cerrado, São Paulo, Edgard Blücher e EDUSP.

SALISBURY, F. B. \& ROSS, C. W. 1992. Plant physiology. Belmont, Wadsworth.

SARMIENTO, G. \& MONASTERIO, M. 1984. Life forms and phenology. In: SARMIENTO, G. (ed). The ecology of tropical savannas. Cambridge, Harvard.

SCHAIK, C. P. van, TERBORGH, J. W. \& WRIGHT, S. J. 1993. The phenology of tropical forests: adaptative significance and consequences for primary consumers. Ann. Rev. Ecol. Syst. 24: 35377. 
TENÓRIO, E. C. 1969. Fenologia de gramíneas. In: CONGR. SOC. BOT. BRAS. 20, Goiânia, 1969. Anais. Soc. Bot. Brasil, Goiânia, p.231-41.

THORNTON, B. \& MILLARD, P. 1993. The effects of nitrogen supply and defoliation on seasonal internal cycling of nitrogen in Mollinia caerulea. J. Exp. Bot. 44: 531-6.

VÁLIO, I. F. M. 1979. Reprodução em plantas superiores. In: FERRI, M. G. (coord) Fisiologia Vegetal. São Paulo, EPU e EDUSP.

WARMING, E. 1892. Lagoa Santa, contribuição para a geografia fitobiológica. In: WARMING, E. \& FERRI, M. G. Lagoa Santa e a vegetação dos cerrados brasileiros. Belo Horizonte, Itatiaia; São Paulo, EDUSP.

WHITE, R. 1972. Studies on mineral ion absorption by plants. I. The absortion and utilization of phosphate by Stylosanthes humilis, Phaseolus atropurpureus and Desmodium intortum. Plant soil 36: 427-47. 